\title{
VARIAÇÃO GENÉTICA ENTRE POPULAÇÕES DE Dalbulus maidis (DeLONG \& WOLCOTT, 1923) (HEMIPTERA: CICADELLIDAE) E MECANISMOS DE SOBREVIVÊNCIA NA ENTRESSAFRA DO MILHO
}

\author{
CHARLES MARTINS DE OLIVEIRA \\ Engenheiro Agrônomo
}

Orientador: Prof. Dr. JOÃO ROBERTO SPOTTI LOPES

Tese apresentada à Escola Superior de Agricultura "Luiz de Queiroz", Universidade de São Paulo, para a obtenção do Título de Doutor em Ciências, Área de Concentração: Entomologia

PIRACICABA

Estado de São Paulo - Brasil

Setembro de 2000 


\section{Dados Internacionais de Catalogação na Publicação (CIP) DIVISÃO DE BIBLIOTECA E DOCUMENTAÇĀO - Campus "LuIZ de Queiroz"/USP}

Oliveira, Charles Martins de

Variação genética entre populaçōes de Dalbu/us maidis (DeLong \& Wolcott, 1923)

(Hemiptera: Cicadellidae) e mecanismos de sobrevivência na entressafra do milho / Charles Martins de Oliveira. - - Piracicaba, 2000.

167 p. : il.

Tese (doutorado) - Escola Superior de Agricultura Luiz de Queiroz, 2000.

Bibliografia.

1. Cicadelideo 2. Cigarrinha-do-milho 3. Entressafra 4. Genética de população 5. Inseto-nocivo 6. Milho 7. Praga agrícola 8. Risca-do-milho 9. Variação genética I. Título

CDD 632.752

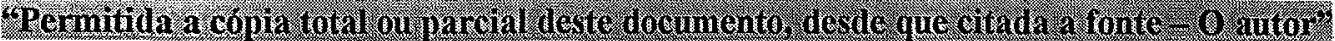

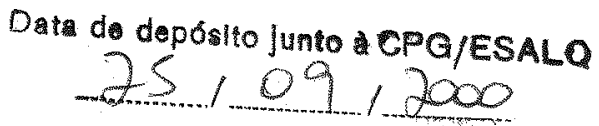


$\mathcal{A}$ Deus, pela iluminação e proteção

durante todos os momentos, $\mathcal{A G R A D E C ̧ O . ~}$

Aos meus pais, José e Adélia; avó, Eutália; irmãos, Fabiana, Crístiane e Frank; por todo amor, carinho e incentivo proporcionado durante toda minha vida.

OFEREÇO.

"Dir-se-á daquele que teve poder econômico e empobreceu, que teve poder político e o perdeu. Mas nunca se dirá de alguém que foi culto e o deixou de ser, porque a cultura é um bem que não se perde, pelo contrário, é um bem cujos limites são ilimitados". 


\section{AGRADECIMENTOS}

À Escola Superior de Agricultura "Luiz de Queiroz", Departamento de Entomologia, Fitopatologia e Zoologia Agrícola, pela oportunidade de realização do Curso de Doutorado.

À Coordenação de Aperfeiçoamento de Pessoal de Ensino Superior (CAPES), pela concessão da bolsa de estudo.

Ao Prof. Dr. João Roberto Spotti Lopes pelo acompanhamento, orientação e amizade no decorrer do curso.

À Prof ${ }^{\mathrm{a}}$. Dr ${ }^{\mathrm{a}}$. Lea Rosa Mourgués Schurter, pela amizade e iniciação na área de Entomologia.

Ao Dr. Lowell R. Nault (Department of Entomology, Ohio Agricultural Research and Development Center, Ohio State University-Wooster, Ohio 44691 USA), pelas sugestões dadas ao presente trabalho.

Aos professores do Departamento de Entomologia, Fitopatologia e Zoologia Agrícola da ESALQ/USP, pela amizade e ensinamentos transmitidos. Aos funcionários do Departamento de Entomologia, em especial à Solange, Regina, Ana Gabriela, Tutú, Dino, Carlinhos, João gorá, Neide e João Forti, pela amizade e auxílios prestados.

Ao Prof. Dr. Carlos Tadeu S. Dias, pelos auxilios prestados na parte estatística.

Ao Prof. Dr. Luis Eduardo Aranha Camargo e Prof ${ }^{a}$. Dr ${ }^{a}$. Maria Helena Pelegrinelli Fungaro, pelos conhecimentos transmitidos na área de biologia molecular.

Às bibliotecárias Eliana M. G. Sabino e Kátia A. Ferraz pelos auxilios prestados. 
À Rosa Maria Molina, Rosenir de Souza Albres, Eng. Agr. Milton Padovam, e em especial ao Tec. Agr. Célio Bernardes da Silveira, pelo valioso auxílio durante a execução do presente estudo.

Aos Senhores Pedro Altimeia, José Dionísio, Aparecido, Eulício, Arlindo, Honório, ao Departamento de Genética e Diretoria da Biblioteca Central da ESALQ/USP, pela permissão concedida à instalação dos experimentos de campo em suas propriedades.

Ao Centro Universitário de Aquidauana (CEUA/UFMS), em especial ao Prof. Dr. Manoel Araécio Uchoa Fernandes, pelo apoio logístico e permissão de uso de suas instalações.

À Rosenir de Souza Albres, Elton Lúcio de Araújo, José Milanez e pelas coletas de cigarninhas.

A todos os colegas e amigos do Departamento de Entomologia, Fitopatologia e Zoologia Agrícola, pela convivência, companheirismo, incentivo e amizade.

Aos meus tios, em especial, a José Adilson, Lucídio Martins e Maria de Lurdes, aos primos Nauto, Edivan, Lucimara, Cilmax, Cilmar e Cecilia, e aos cunhados Lucas, Danilo e Simone, pelo carinho, amizade e incentivo.

Aos amigos, Alcides, Alexander, Cláudio Marcelo, Cidoca, Daniella, Eduardo, Elton, Érica, Fernando, Geraldo, Gerson, Jorge, Fito, Luciano e Sandra, Marcelo Gomes, Marcone, Mônica e Lino, Rosangela e Silvino, Rodrigo Almeida, Rodrigo Krügner, Silvia, Simone Prado, Simone Mendes, Solange, Ranyse, Teresinha e Vargas, pelo companheirismo, amizade, carinho e incentivo em todos os momentos.

Um agradecimento especial à minha namorada, Marina Regina Frizzas, companheira de todos os momentos, e a quem dedico grande carinho.

E a todas as pessoas que contribuíram, direta ou indiretamente, para a realização deste trabalho. 


\section{SUMÁRIO}

Página

LISTA DE TABELAS ............................................................................... viii

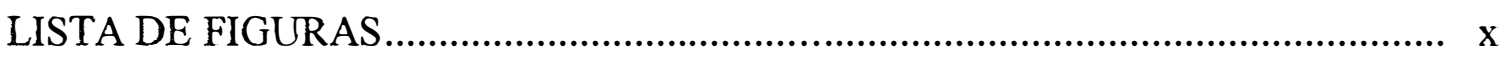

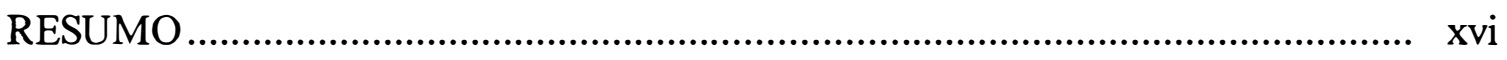

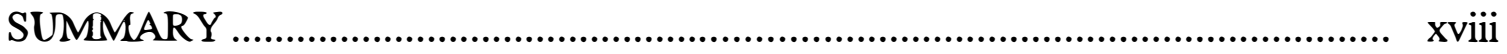

1. INTRODUÇÃO ........................................................................................... 1

2. REVISÃO DE LITERATURA .................................................................. 4

2.1. A cultura do milho (Zea mays L.) no Brasil ................................................ 4

2.2. A cigarrinha-do-milho Dalbulus maidis (DeLong \& Wolcott) ..................... 5

2.2.1. Distribuição geográfica e plantas hospedeiras ...................................... 6

2.2.2. Época de ocorrência e perdas causadas à cultura ................................. 7

2.2.3. Possiveis estratégias de sobrevivência de $D$. maidis na entressafra do

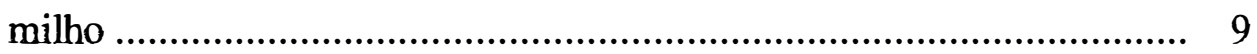

2.3. Migração em Insetos .............................................................................. 11

2.3.1. Migração por correntes ventos ..............................................................13

2.3.2. Exemplos de comportamento migratório em insetos .................................15

2.4. DNA polimórfico amplificado ao acaso (RAPD-PCR).....................................20

2.4.1. Utilização da técnica de RAPD-PCR em Entomologia.............................24

2.4.2. Preservação de DNA para análises genéticas..............................................32 
3. MIGRAÇÃO COMO UMA ESTRATÉGIA DE SOBREVIVÊNCIA DE Dalbulus maidis (DeLONG \& WOLCOTT) (HEMIPTERA: CICADELLIDAE) DURANTE A ENTRESSAFRA DO MILHO NO BRASIL CENTRAL ........................34

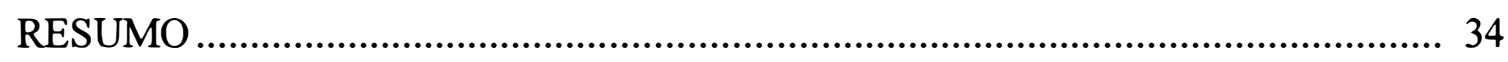

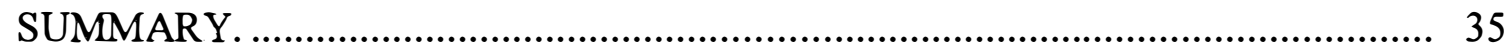

3.1. INTRODUÇÃO ................................................................................ 37

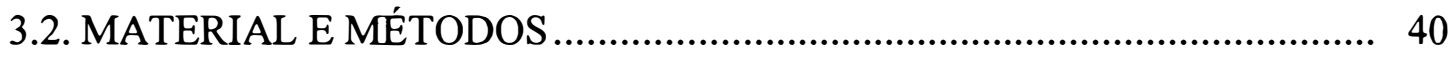

3.2.1. Características das áreas experimentais ................................................ 40

3.2.2. Coletas com cartões adesivos ............................................................ 44

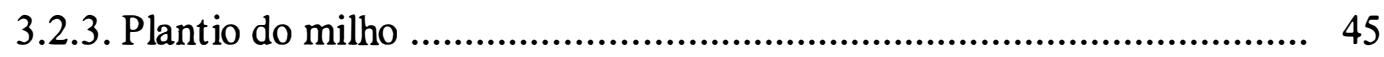

3.2.4. Procedimentos de entressafra....................................................... 45

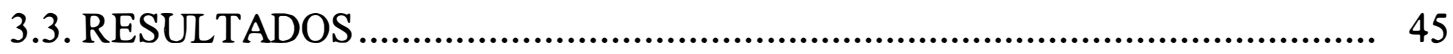

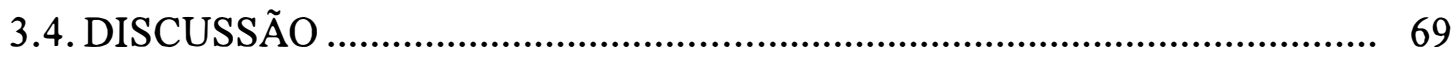

4. VARIAÇÃO GENÉTICA ENTRE E DENTRO DE ALGUMAS POPULAÇÕES

DE Dalbulus maidis (DeLONG \& WOLCOTT) (HEMIPTERA: CICADELLIDAE) NO BRASIL............................................................... 80

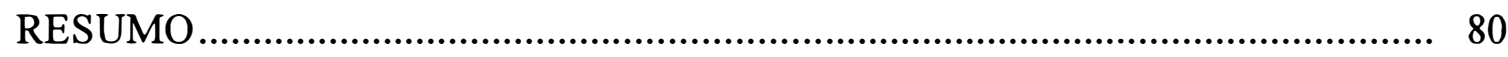

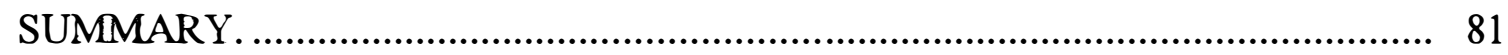

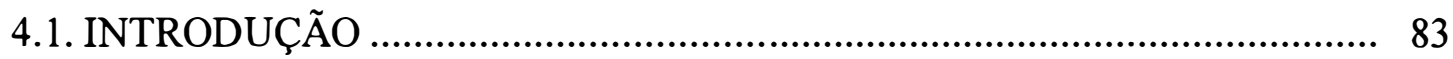

4.2. MATERIAL E MÉTODOS ............................................................... 85

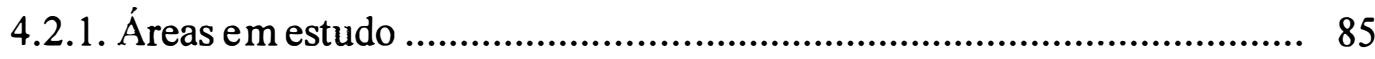

4.2.2. Obtenção de cigarrinhas ....................................................................... 86

4.2.3. Extração do DNA .......................................................................... 88

4.2.4. Otimização das condições de amplificação ............................................ 89

4.2.5. Amplificação via RAPD-PCR ............................................................. 89

4.2.6. Análise dos dados ................................................................................ 91

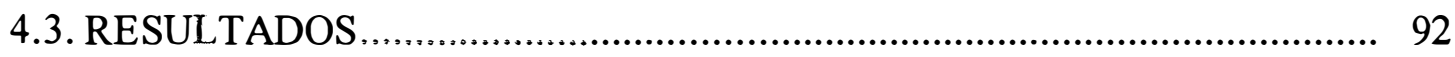

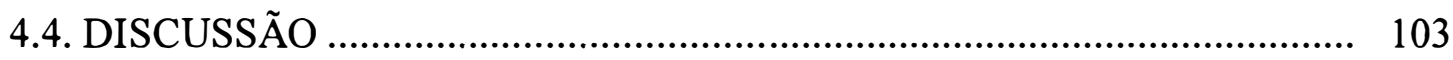


5. COMPARAÇÃO DE MÉTODOS DE PRESERVAÇÃO DE Dalbulus maidis (DeLONG \& WOLCOTT) (HEMIPTERA: CICADELLIDAE) PARA USO EM RAPD-PCR

SUMMARY. 108

5.1. INTRODUÇÃO 108

5.2. MATERIAL E MÉTODOS ............................................................ 110

5.2.1. Métodos de conservação ................................................................. 110

5.2.2. Extração do DNA ....................................................................... 110

5.2.3. Amplificação via RAPD-PCR....................................................... 112

5.2.4. Análise dos dados...................................................................... 112

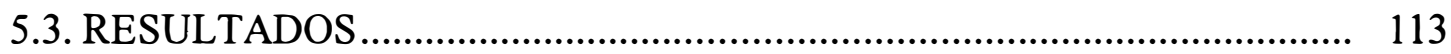

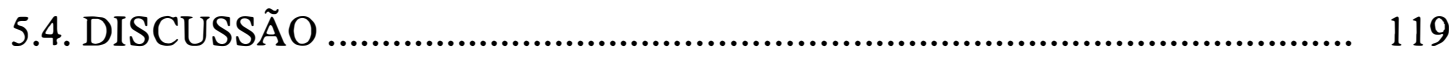

6. EVIDÊNCIA DE DISSEMINAÇÃO DE MOLICUTES DO MILHO A LONGAS DISTÂNCIAS PELO VETOR Dalbulus maidis (DeLONG \& WOLCOTT) (HEMIPTERA: CICADELLIDAE) ............................................ 123

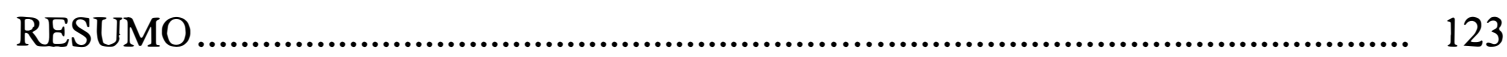

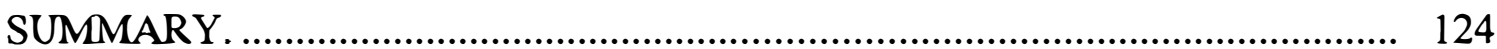

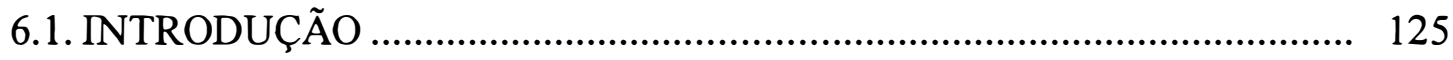

6.2. MATERIAL E MÉTODOS ................................................................ 126

6.2.1. Características das áreas experimentais e coleta de cigarrinhas .......... 126

6.2.2. Bioensaios de transmissão ............................................................ 127

6.3. RESULTADOS E DISCUSSÃO_...................................................... 129

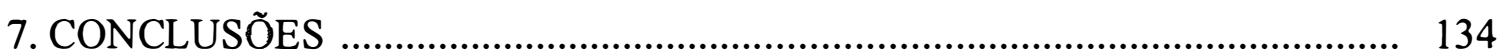

REFERÊNCIAS BIBLIOGRÁFICAS ...................................................... 136

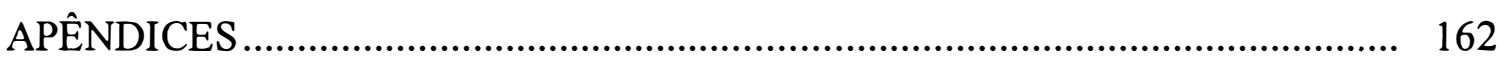




\section{LISTA DE TABELAS}

TABELA

Página

1 Número total e média de adultos de Dalbulus maidis coletados por cartão adesivo amarelo $(7 \times 12 \mathrm{~cm})$ e placa de metal amarela nas seis áreas experimentais, durante todo o estudo.

2 Locais e datas de amostragem de populações de Dalbulus maidis em milho em cinco municípios Brasileiros e em Anastácio/MS nas safras $1997 / 98$ e 1998/99.

3 Seqüência de bases de todos os primers testados e daqueles que foram efetivamente utilizados nos estudos com populações de Dalbulus maidis.

4 Valores médios do índice de similaridade de Jaccard (J), baseado em marcadores RAPD-PCR, pela comparação dos padrões RAPD-PCR dos indivíduos, dentro de cada população de Dalbulus maidis amostrada em diferentes municípios Brasileiros e na região de Anastácio/MS. 
5 Valores médios do índice de similaridade de Jaccard (J), baseado em marcadores RAPD-PCR, pela comparação dos padrões RAPD-PCR dos indivíduos, entre as populações de Dalbulus maidis amostradas em diferentes municípios Brasileiros e na região de Anastácio/MS. .98

6 Quantidades médias ( \pm desvio padrão da média) de DNA genômico total (ng $\mathrm{DNA} / \mu \mathrm{l} \mathrm{TE}$ ) extraída por espécime de D. maidis, após períodos de armazenamento de 1 a 70 dias, sob diferentes métodos de preservação.

7 Quantidades médias ( \pm desvio padrão da média) de DNA genômico total (ng $\mathrm{DNA} / \mu \mathrm{T} \mathrm{TE}$ ) extraída por espécime de D. maidis, após períodos de armazenamento de 80 a 210 dias, sob diferentes métodos de preservação.

8 Estimativas de infectividade natural por Spiroplasma kunkelii e fitoplasma em adultos de Dalbulus maidis amostrados na região de Anastácio/MS, em diferentes áreas e fases da cultura do milho, na safra 1997/98 e 1998/99. 


\section{LISTA DE FIGURAS}

FIGURA

Página

1 Localização das áreas experimentais em Anastácio/MS, e Piracicaba/SP, com a distância aproximada entre os municípios e entre as áreas.

2 Croquis das áreas experimentais. A) área I, B) área II, C) área III, D) área $\mathrm{IV}, \mathrm{E}$ ) área $\mathrm{Va}, \mathrm{F}$ ) área $\mathrm{Vb}$, todas localizadas no município de Anastácio/MS e G) área VI, no município de Piracicaba/SP. Os números de 1-8 indicam a posição dos vergalhões onde foram colocados os cartões adesivos amarelos $(7 \times 12 \mathrm{~cm})$ e as placas de metal amarelas $(30 \times 30 \mathrm{~cm})$ com cola "sticky". Os cartões adesivos foram posicionados nas alturas de $0,5,1,5$ e $2,5 \mathrm{~m}$ nos vergalhões $1,3,4$, e 6 de A-E, 1 e 3 em F e $1-6$ em G, e nas alturas de 0,5 e $1,5 \mathrm{~m}$ nos vergalhões 2, 5, 7 e 8 de A-E e 2 e 4 em F. Em G, o número 7 indica a posição das placas de metal amarelas colocadas nas alturas de 7, 13 (2 placas) e $16 \mathrm{~m}$ (4 placas). $\mathrm{N}$ indica o Norte magnético.

3 Número médio de adultos de Dalbulus maidis coletados por cartão adesivo amarelo no município de Anastácio/MS, em áreas onde o milho era plantado uma vez por ano: A) área I e B) área II (período de agosto/97 a dezembro/99). $\square$ cultura do milho, $\square$ outra cultura que não o milho ou plantas daninhas e $\square$ preparo do solo.

4 Número médio de adultos de Dalbulus maidis coletados por cartão adesivo amarelo no município de Anastácio/MS, em áreas onde o milho não era plantado há pelo menos 5 anos: A) área III (período de agosto/97 a dezembro/99) e B) área IV (período de setembro/97 a dezembro/99). $\square$ cultura do milho, $\square$ outra cultura que não o milho ou plantas daninhas e $\square$ preparo do solo. 
$5 \quad$ Número médio de adultos de Dalbulus maidis coletados por cartão adesivo amarelo no município de Anastácio/MS, em áreas onde o milho não era plantado há pelo menos 5 anos: $\mathrm{A}$ ) área $\mathrm{Va} \mathrm{e} \mathrm{B}$ ) área $\mathrm{Vb}$ (período de setembro/98 a dezembro/99). $\square$ cultura do milho, $\square$ outra cultura que não o milho ou plantas daninhas e $\square$ preparo do solo.

Número médio de adultos de Dalbulus maidis coletados por cartão adesivo amarelo no município de Piracicaba/SP, em área onde o milho era plantado continuamente. Área VI (período de setembro/97 a dezembro/99). $\square$ cultura do milho, $\square$ outra cultura que não o milho ou plantas daninhas e $\square$ preparo do solo.

$7 \quad$ Número médio de adultos de Dalbulus maidis coletados por placa de metal amarelas com cola "sticky", no município de Piracicaba/SP, nas alturas de 7, 13 e $16 \mathrm{~m}$ (período de fevereiro/98 a fevereiro/00). A) fềmeas e B) machos.

8 Número médio de adultos fềmeas e machos de Dalbulus maidis coletados por cartão adesivo amarelo no município de Anastácio/MS, em áreas onde o milho era plantado uma vez por ano: A) área I e B) área II (período de agosto/97 a dezembro/99)

Número médio de adultos fềmeas e machos de Dalbulus maidis coletados por cartão adesivo amarelo no município de Anastácio/MS, em áreas onde o milho não era plantado há pelo menos 5 anos: A) área III (período de agosto/97 a dezembro/99) e B) área IV (período de setembro/97 a dezembro/99)

10 Número médio de adultos fềmeas e machos de Dalbulus maidis coletados por cartão adesivo amarelo no município de Anastácio/MS, em áreas onde o milho não era plantado há pelo menos 5 anos: A) área $\mathrm{Va}$ e B) área $\mathrm{Vb}$ (período de setembro/98 a dezembro/99).

11 Número médio de adultos fềmeas e machos de Dalbulus maidis coletados por cartão adesivo amarelo no município de Piracicaba/SP, em área onde o milho era plantado continuamente. Área VI (período de setembro/97 a dezembro/99).

12 Número médio de adultos de Dalbulus maidis coletados por cartão adesivo amarelo nas alturas de $0,5,1,5$ e $2,5 \mathrm{~m}$, no município de Anastácio/MS, em áreas onde o milho era plantado uma vez por ano: A) área I e B) área II (período de agosto/97 a dezembro/99). 
13 Número médio de adultos de Dalbulus maidis coletados por cartão adesivo amarelo nas alturas de 0,5, 1,5 e 2,5 m, no município de Anastácio/MS, em áreas onde o milho não era plantado há pelo menos 5 anos: A) área III (período de agosto/97 a dezembro/99) e B) área IV (período de setembro/97 a dezembro/99).

14 Número médio de adultos de Dalbulus maidis coletados por cartão adesivo amarelo nas alturas de 0,5, 1,5 e 2,5 m, no município de Anastácio/MS, em áreas onde o milho não era plantado há pelo menos 5 anos: $\mathrm{A}$ ) área $\mathrm{Va}$ e $\mathrm{B}$ ) área $\mathrm{Vb}$ (período de setembro/98 a dezembro/99)...

15 Número médio de adultos de Dalbulus maidis coletados por cartão adesivo amarelo nas alturas de $0,5,1,5$ e $2,5 \mathrm{~m}$, no município de Piracicaba/SP, em área onde o milho era plantado continuamente. Área VI (período de setembro/97 a dezembro/99)

16 Número médio de adultos de Dalbulus maidis coletados por cartão adesivo amarelo em diferentes posições (ver Figura 2), no município de Anastácio/MS, em áreas onde o milho era plantado uma vez por ano: A) área I e B) área II (período de agosto/97 a dezembro/99)

17 Número médio de adultos de Dalbulus maidis coletados por cartão adesivo amarelo em diferentes posições (ver Figura 2), no município de Anastácio/MS, em áreas onde o milho não era plantado há pelo menos 5 anos: A) área III (período de agosto/97 a dezembro/99) e B) área IV (período de setembro/97 a dezembro/99).

18 Número médio de adultos de Dalbulus maidis coletados por cartão adesivo amarelo em diferentes posições (ver Figura 2), no município de Anastácio/MS, em áreas onde o milho não era plantado há pelo menos 5 anos: $\mathrm{A}$ ) área $\mathrm{Va}$ e $\mathrm{B}$ ) área $\mathrm{Vb}$ (período de setembro/98 a dezembro/99)...

19 Número médio de adultos de Dalbulus maidis coletados por cartão adesivo amarelo em diferentes posições (ver Figura 2), no município de Piracicaba/SP, em área onde o milho era plantado continuamente. Área VI (período de setembro/97 a dezembro/99)

20 Número médio de adultos de Dalbulus maidis coletados nas faces norte e sul dos cartões adesivos amarelos, no município de Anastácio/MS, em áreas onde o milho era plantado uma vez por ano: A) área I e B) área II (período de agosto/97 a dezembro/99) 
21 Número médio de adultos de Dalbulus maidis coletados nas faces norte e sul dos cartões adesivos amarelos, no município de Anastácio/MS, em áreas onde o milho não era plantado há pelo menos 5 anos: A) área III (período de agosto/97 a dezembro/99) e B) área IV (período de setembro/97 a dezembro/99).

22 Número médio de adultos de Dalbulus maidis coletados nas faces norte e sul dos cartões adesivos amarelos, no município de Anastácio/MS, em áreas onde o milho não era plantado há pelo menos 5 anos: A) área Va e B) área $\mathrm{Vb}$ (período de setembro/98 a dezembro/99).

23 Número médio de adultos de Dalbulus maidis coletados nas faces norte e sul dos cartões adesivos amarelos, no município de Piracicaba/SP, em área onde o milho era plantado continuamente. Área VI (período de setembro/97 a dezembro/99)

24 Localização geográfica dos municípios de coleta de populações de Dalbulus maidis no Brasil e das áreas localizadas em Anastácio/MS, com a distância aproximada entre as mesmas.

25 Produtos da amplificação de DNA de Dalbulus maidis via RAPD-PCR pelo primer OPA-07, em gel de agarose 1,4\%. Dez espécimes avaliados de cada uma das 7 populações amostradas no município de Anastácio/MS (áreas IA, IB, IIA, IIB, IIIA, IVA e IVB), na safra 1997/98. M - marcador (100 base-pair Ladder) (Pharmacia) e C controle negativo (todos os componentes da reação menos o DNA).

26 Produtos da amplificação de DNA de Dalbulus maidis via RAPD-PCR pelo primer OPE-14, em gel de agarose 1,4\%. Dez espécimes avaliados de cada uma das 6 populações amostradas no município de Anastácio/MS (áreas IA, IB, IIB, IVA, IVB e VB), na safra 1998/99. M - marcador (100 base-pair Ladder) (Pharmacia) e C - controle negativo (todos os componentes da reação menos o DNA).

27 Produtos da amplificação de DNA de Dalbulus maidis via RAPD-PCR pelo primer OPC-05, em gel de agarose 1,4\%. Dez espécimes avaliados de cada uma das 5 populações amostradas nos municípios de Chapecó/SC, Bom Jardim da Serra/SC, Anastácio/MS, Piracicaba/SP e Mossoró/RN. M - marcador (100 base-pair Ladder) (Pharmacia) e C controle negativo (todos os componentes da reação menos o DNA). 
28 Dendrograma UPGMA baseado no coeficiente de similaridade de Jaccard $(\mathrm{J})$, gerado a partir de marcadores RAPD-PCR de 10 espécimes de Dalbulus maidis de cada uma das 7 populações amostradas no município de Anastácio/MS (áreas IA, IB, IIA, IIB, IIIA, IVA e IVB), na safra 1997/98.

29 Dendrograma UPGMA baseado no coeficiente de similaridade de Jaccard $(J)$, gerado a partir de marcadores RAPD-PCR de 10 espécimes de Dalbulus maidis de cada uma das 6 populações amostradas no município de Anastácio/MS (áreas IA, IB, IIB, IVA, IVB e VB), na safra 1998/99.

30 Dendrograma UPGMA baseado no coeficiente de similaridade de Jaccard (J), gerado a partir de marcadores RAPD-PCR de 10 espécimes de Dalbulus maidis de cada uma das 5 populações amostradas nos municípios de Chapecó/SC, Bom Jardim da Serra/SC, Anastácio/MS, Piracicaba/SP e Mossoró/RN.

31 Dendrograma UPGMA baseado no coeficiente de similaridade de Jaccard $(J)$ gerado a partir de marcadores RAPD-PCR para populações de Dalbulus maidis. (A) sete populações coletadas em Anastácio/MS na safra 97/98, (B) seis populações coletadas em Anastácio/MS na safra 98/99 e (C) cinco populações coletadas nos municípios de Chapecó/SC, Bom Jardim da Serra/SC, Anastácio/MS, Piracicaba/SP e Mossoró/RN. .

32 DNA genômico total em gel de agarose $0,8 \%$, extraído de Dalbulus maidis, armazenado sob diferentes condições. Colunas 1-5, padrão Lambda DNA (Pharmacia) (20, 50, 80, 110 e $150 \mathrm{ng}$ ); 6, material fresco; 7, 15, 23 e 31, congelamento $(1,70,120$ e 210 dias, respectivamente); $8,16,24$ e 32 , álcool etilico 70\% (ambiente) (1, 70, 120 e 210 dias, respectivamente); $9,17,25$ e 33, álcool etílico $70 \%$ ($\left.20^{\circ} \mathrm{C}\right)(1,70,120$ e 210 dias, respectivamente); 10, 18, 26 e 34, álcool etílico absoluto (ambiente) (1, 70, 120 e 210 dias, respectivamente); 11, 19,27 e 35 , álcool etílico absoluto $\left(-20^{\circ} \mathrm{C}\right)(1,70,120$ e 210 dias, respectivamente); 12, 20, 28 e 36 , seco ao ar (1,70,120 e 210 , dias respectivamente); 13, 21, 29 e 37, tampão de extração (inseto inteiro) (ambiente) (1, 70, 120 e 210 dias, respectivamente); 14, 22, 30 e 38 tampão de extração (inseto macerado) (ambiente) (1, 70, 120 e 210 dias, respectivamente). 
33 Produtos da amplificação de DNA de Dalbulus maidis via RAPD-PCR pelo primer OPA-A04 em gel de agarose $1,4 \%$, a partir de indivíduos armazenados por períodos sucessivos sob diferentes condições. (A) 1 dia; (B) 70 dias; (C) 120 dias e (D) 210 dias. Coluna 1, marcador (100 base-pair Laedder) (Pharmacia); 2, material fresco; 3, congelamento; 4, álcool etílico $70 \%$ (ambiente); 5 , álcool etílico $70 \%\left(-20^{\circ} \mathrm{C}\right) ; 6$, álcool etílico absoluto (ambiente); 7 , álcool etílico absoluto $\left(-20^{\circ} \mathrm{C}\right) ; 8$, seco ao ar; 9, tampão de extração (inseto inteiro) (ambiente); 10, tampão de extração (inseto macerado) (ambiente); 11, controle negativo (todos os componentes da reação menos o DNA) e 12 , marcador (Kilobase ${ }^{\mathrm{TM}}$ DNA marker) (Pharmacia).

34 Localização do município de Anastácio/MS e das cinco áreas experimentais e distância aproximada entre as mesmas.... 


\title{
VARIAÇÃO GENÉTICA ENTRE POPULAÇÕES DE \\ Dalbulus maidis (DeLONG \& WOLCOTT, 1923) (HEMIPTERA: \\ CICADELLIDAE) E MECANISMOS DE SOBREVIVÊNCIA NA ENTRESSAFRA DO MILHO
}

\author{
Autor: Charles Martins de Oliveira \\ Orientador: Prof. Dr. João Roberto Spotti Lopes
}

\section{RESUMO}

A doença conhecida como enfezamento do milho, associada aos molicutes Spiroplasma kunkelii Whitcomb et al. e fitoplasma do milho ("maize bushy stunt phytoplasma"), tem adquirido importância crescente no Brasil nos últimos anos. Em função da expansão do cultivo do milho fora da época normal e do uso de irrigação em algumas regiões, tem ocorrido superposição dos ciclos da cultura no campo, favorecendo o aumento das populações desses patógenos bem como do inseto vetor, Dalbulus maidis. Nesta pesquisa foram realizados estudos ecológicos e de genética de populações de $D$. maidis para melhor compreender o seu mecanismo de sobrevivência na entressafra do milho e, com isso, aprimorar o manejo deste vetor visando ao controle do enfezamento. Por ser o milho o único hospedeiro conhecido de D. maidis no Brasil, esta cigarrinha parece ter duas alternativas para sua sobrevivência na ausência da cultura: migração e/ou dormência em restos culturais ou áreas adjacentes. Para investigar estas possibilidades, populações de $D$. maidis foram monitoradas quinzenalmente através de cartões adesivos amarelos dupla face $(7 \times 12 \mathrm{~cm})$ por períodos que variaram de 15 a 29 meses, no município de Anastácio/MS. Esta região é caracterizada por áreas extensas de pastagens e por apresentar pequenas áreas de plantio de milho com um longo período de entressafra (6-7 meses). O monitoramento foi realizado em cinco áreas representando 
duas situações distintas: a) áreas (I e II) onde o milho era plantado uma vez por ano a partir de outubro; e b) áreas (III, IV, Va e Vb) de pastagem, onde o milho não era cultivado há pelo menos 5 anos. Simultaneamente, realizou-se monitoramento em uma área de Piracicaba/SP, onde o milho era plantado o ano inteiro (área VI). Paralelamente, foram realizadas análises RAPD-PCR para comparação genética de populações desta cigarrinha em Anastácio/MS e de outras quatro localidades do Centro-Sul e Nordeste do Brasil, sendo também avaliados métodos simples de preservação de espécimes de $D$. maidis para utilização do DNA em análise genética. As coletas com cartões adesivos em Anastácio/MS mostraram que D. maidis coloniza plantios de milho mesmo em áreas de pastagens perenes, onde esse cereal não era cultivado há muitos anos. Picos populacionais simultâneos foram observados na entressafra em todas as áreas estudadas, sendo maiores em locais de solo exposto por aração; assim, o preparo do solo parece exercer influência na escolha da área para o pouso por adultos de D. maidis. Estas informações, aliadas ao fato de que $D$. maidis não foi capturada em vegetação adjacente aos plantios de milho por vários métodos de amostragem (cartões adesivos, rede de varredura e succionador motorizado), sugerem que os indivíduos colonizadores desses plantios eram imigrantes de locais distantes. A hipótese de migração é reforçada pelas análises de RAPD-PCR que indicaram elevado fluxo gênico entre as populações do Centro-Sul do Brasil. Dos métodos avaliados para preservação do DNA de D. maidis, álcool etílico absoluto ou $70 \%$ a $-20^{\circ} \mathrm{C}$, tampão de extração (inseto macerado e inteiro) e principalmente congelamento a $-20^{\circ} \mathrm{C}$, mostraram-se os mais adequados. Insetos preservados em álcool etílico absoluto ou $70 \%$, em temperatura ambiente, e insetos secos ao ar mostraram-se imprestáveis para RAPD-PCR após 120, 60 e 10 dias, de armazenamento, respectivamente. Através de bioensaios de transmissão com adultos de D. maidis coletados nos plantios de milho em Anastácio/MS verificaram-se taxas infectividade por S. kunkelii e fitoplasma que variaram de 1,9 a $19,7 \%$ e 1,1 a $3,6 \%$, respectivamente, suportando a hipótese de que esses patógenos possam utilizar o vetor para sobrevivência na entressafra e disseminação a longas distâncias. 


\title{
GENETIC VARIATION AMONG POPULATIONS OF
}

\section{Dalbulus maidis (DELONG \& WOLCOTT) (HEMIPTERA: CICADELLIDAE) \\ AND STRATEGIES FOR SURVIVAL DURING CORN OVERSEASON}

\author{
Author: Charles Martins de Oliveira
}

Adviser: Prof. Dr. João Roberto Spotti Lopes

SUMMARY - The corn stunt disease, associated with the mollicutes Spiroplasma kunkelii Whitcomb et al. and maize bushy stunt phytoplasma, became very important in Brazil in the 1990's. As result of changes in the cultural practices in some regions, such as the increase in irrigated areas and the cultivation of a second maize crop in late summer, crop cycles are overlapping in the field, favoring the increase of populations of these pathogens as well as of the leafhopper vector, Dalbulus maidis. In this research, studies on ecology and population genetics of $D$. maidis were carried out to better understand its survival mechanism in the corn overseason, in order to improve vector management and disease control. Because maize is the only known host of D. maidis in Brazil, this leafhopper has two possible strategies for survival during corn overseason: migration or dormancy in crop remains or adjacent areas. To investigate these possibilities, populations of $D$. maidis were monitored biweekly by double-faced yellow sticky cards $(7 \times 12 \mathrm{~cm})$ for periods that varied from 15 to 29 months, in the region of Anastácio, State of Mato Grosso do Sul (MS). This region is characterized by extensive areas of perennial pastures, where maize is planted in small and isolated areas, with a long overseason period (6-7 months). The survey was accomplished in five areas representing two different situations: a) areas (I and II) where maize is grown once a year in the spring, in the same field plot; and b) areas (III, IV, VA and VB) of pasture where maize had not been cultivated, at least in the previous 5 years. A similar and simultaneous survey was carried out in one area of Piracicaba, State of São Paulo (SP), where is grown year round (area VI). RAPD-PCR analyses were used for genetic comparisons of $D$. maidis populations in Anastácio/MS (micro region), as well as of populations from distant localities in the center-south (4) and northeast (1) of Brazil 
(macro region). In addition, a study was carried out to evaluate several methods of preservation of $D$. maidis specimens for use of its DNA in genetic analysis. The survey with sticky cards in Anastácio/MS showed that D. maidis colonized all maize plantings, even in the isolated areas of pasture where this cereal had not been cultivated before. Simultaneous population peaks were observed in the overseason in all areas studied; the peaks were higher areas where the soil had been exposed by plowing, suggesting that plowed soil might serve as a cue in the choice of the area for landing by adults of $D$. maidis. These observations, allied to the fact that D. maidis was not captured in vegetation adjacent to the maize plantings after numerous samplings with different methods (yellow sticky cards, sweep net and suction trap), suggest that the leafhoppers that colonized maize plantings in Anastácio/MS were immigrant from distant areas. The migration hypothesis is reinforced by the RAPD-PCR analyses that indicated high gene flow among the populations of the center-south of Brazil. Among methods tested for preservation of DNA of $D$. maidis, absolute or $70 \%$ ethyl alcohol at $-20^{\circ} \mathrm{C}$, extraction buffer (homogenized or whole insect) and especially freezing at $-20^{\circ} \mathrm{C}$ were the most appropriate. Insects preserved in absolute ethyl alcohol or $70 \%$ ethyl at room temperature and air-dried insects were inappropriate for RAPD-PCR after 120, 60 and 10 days of storage, respectively. D. maidis adults collected in the maize plantings of Anastácio/MS showed infectivity rates by $S$. kunkelii and phytoplasma that varied from 1,9 to $19,7 \%$ and 1,1 to $3,6 \%$, respectively, supporting the hypothesis that these pathogens use the vector for survival and long-distance spread in the corn overseason. 


\section{INTRODUÇÃO}

O milho (Zea mays L.) representa uma das principais culturas do mundo, tendo ampla utilização na indústria, alimentação humana e animal (Fancelli \& Neto, 2000). No cenário nacional destaca-se como um dos cereais mais cultivados, sendo plantado em todos os Estados da Federação (Fancelli, 1988). Dentre os principais problemas da cultura destaca-se o ataque de pragas, pela sua grande influência no rendimento e na lucratividade da lavoura. Neste contexto, a cigarrinha-do-milho Dalbulus maidis (DeLong \& Wolcott) tem se mostrado como uma das mais sérias pragas da cultura, pela sua capacidade de transmitir, de forma persistente e propagativa, o vírus da risca do milho ("maize rayado fino virus"-MRFV) e dois molicutes associados ao enfezamento do milho, Spiroplasma kunkelii Whitcomb et al. ("corn stunt spiroplasma"CSS) e o fitoplasma do milho ("maize bushy stunt phytoplasma"-MBSP) (Nault, 1980; 1990). Sua importância no Brasil tem aumentado principalmente em função da utilização de híbridos suscetíveis (Oliveira et al., 1998; Waquil et al., 1996), do plantio do milho fora da época normal e da adoção de práticas como a irrigação. Tais práticas têm permitido a superposição dos ciclos da cultura no campo e alterado alguns patossistemas, principalmente aqueles que envolvem insetos vetores (Oliveira et al., 1997).

O conhecimento de aspectos ecológicos de uma determinada praga pode ser o ponto de partida para o delineamento de medidas de controle. Para D. maidis, cujo hospedeiro natural é o milho, poucas são as informações a respeito de suas estratégias de sobrevivência na entressafra e dos fatores que condicionam o aparecimento súbito de populações desta cigarrinha em campos de milho recém plantados. Hipóteses como 
migração, local ou a grandes distâncias, diapausa, permanência em restos culturais, utilização de plantas hospedeiras alternativas têm sido estudadas, principalmente no México (Barnes, 1954; Larsen et al., 1992; Nault, 1990; Taylor et al., 1993). No Brasil, estudos com esta espécie são incipientes e não têm acompanhado a crescente importância desta praga na cultura do milho.

Estudos envolvendo o monitoramento de populações da cigarrinha-do-milho através de armadilhas adesivas, como os que foram realizados no México (Barnes, 1954; Larsen et al., 1992), podem ser úteis na busca de respostas para os mecanismos de sobrevivência de $D$. maidis na entressafra do milho. Por outro lado, técnicas moleculares como RAPD-PCR têm sido importantes ferramentas na análise de populações naturais de insetos (Infante-Malachias, 1999; Lin et al., 1999; Skinner \& Camacho, 1995). Estas técnicas podem servir como evidências adicionais, em estudos de ecologia, para se avaliar o nível de fluxo gênico entre populações, o que nos dá uma idéia do potencial de migração (Hoole et al., 1999) ou do isolamento entre as mesmas, podendo gerar diferenciações até mesmo em nível morfológico. Variações morfológicas entre populações de $D$. maidis de diversas localidades do Brasil foram constatadas por Oliveira (1996).

O objetivo do presente trabalho foi investigar a(s) possivel(is) estratégia(s) de sobrevivência de populações de $D$. maidis na entressafra do milho. Para tal, realizou-se um monitoramento populacional desse inseto em áreas com características distintas quanto à frequiência de cultivo de milho e duração da entressafra, em Piracicaba/SP (área de plantio escalonado) e na região de Anastácio/MS, onde predominam pastagens perenes e pequenos plantios de subsistência, com entressafra prolongada. Como base para o estudo ecológico, avaliou-se a estrutura genética de populações desta cigarrinha de Anastácio/MS e de outras quatro localidades do Centro-Sul e Nordeste do Brasil, através da técnica de RAPD-PCR. Devido à necessidade de preservação do DNA de espécimes coletados em regiões distantes e épocas distintas, foram avaliados métodos simples de armazenamento da cigarrinha-do-milho para as análises genéticas. Em caráter complementar, investigou-se a hipótese de sobrevivência dos molicutes, espiroplasma 
(S. kunkelii) e fitoplasma, no vetor D. maidis durante a entressafra do milho, na região de Anastácio/MS. 


\section{REVISÃO DE LITERATURA}

\subsection{A cultura do milho (Zea mays $L$.) no Brasil}

O milho, em função de seu potencial produtivo, composição química e valor nutritivo, constitui-se em um dos mais importantes cereais cultivados e consumidos no mundo. Devido a sua multiplicidade de aplicações, quer na alimentação humana quer na alimentação animal, assume relevante papel sócio-econômico, além de constituir-se em indispensável matéria-prima impulsionadora de diversificados complexos agroindustriais (Fancelli \& Neto, 2000) sendo utilizado em mais de 3.500 diferentes produtos (NCGA, 1997). Para a safra 1999/00, a estimativa de produção é de mais 599 milhões de toneladas, tornando-se o milho o cereal mais produzido no mundo. O Brasil ocupa a terceira posição mundial em produção, respondendo por 5,2\% do montante produzido (FNP, 2000). Tanto a área plantada como a produtividade brasileira vem aumentando muito nas últimas décadas (Almeida, 1993; Magalhães et al., 1995). De 1979 a 1999 houve um aumento de aproximadamente 8\% na área plantada, passando de 11,3 milhões de hectares em 79 para 12,2 milhões de hectares atuais e a produção aumentou 90\%, passando de 16,3 milhões de toneladas para 30,9 milhões de toneladas, no mesmo período (FNP, 2000; Anuário Estatístico do Brasil, 1979). Este aumento foi devido, principalmente, à utilização de híbridos mais produtivos, melhoria nas técnicas de condução da cultura e plantios adicionais fora da época convencional de plantio, conhecido como milho "safrinha" (Garcia, 1997), que hoje responde por 15,8\% da produção nacional desta cultura (FNP, 2000). Os Estados maiores produtores são: 
Paraná $(25,0 \%)$, Minas Gerais $(14,0 \%)$ e São Paulo (12,3\%), que juntos produzem $51,3 \%$ de toda a safra brasileira (FNP, 2000).

\subsection{A cigarrinha-do-milho Dalbulus maidis (DeLong \& Wolcott)}

D. maidis pertence à ordem Hemiptera, familia Cicadellidae, subfamília Deltocephalinae e tribo Macrostelini (Triplehorn \& Nault, 1985). São insetos diminutos com cerca de 3,7 a 4,3 mm de comprimento, de coloração amarelo-palha, sendo as fềmeas maiores que os machos. Os adultos apresentam duas manchas circulares negras bem marcadas na coroa, o que permite diferenciá-los das outras cigarrinhas comumente encontradas na cultura do milho (Marín, 1987; Oliveira 1996; Triplehorn \& Nault, 1985). Localizam-se nos ponteiros, principalmente no interior do cartucho das plantas, e são mais ativos que as ninfas (Marín, 1987). Porém, a identificação exata da espécie só é possível através da observação da genitália masculina, auxiliada pela forma do sétimo esternito da fềmea (Barnes, 1954; Triplehorn \& Nault, 1985).

D. maidis tem sido relatada como a única espécie do gênero Dalbulus DeLong encontrada em milho no Brasil (Oliveira, 1996). Entretanto, no México que é o centro de origem do gênero (Nault \& DeLong, 1980), mais 12 espécies são conhecidas e estas utilizam como hospedeiros primários o milho, outras espécies do gênero Zea L. (teosintos) e também gramíneas do gênero Tripsacum L. Estas espécies são $D$. quiquenotatus DeLong \& Nault, D. chiapensis Triplehorn \& Nault, D. gramalotes Triplehorn \& Nault, D. tripsacoides DeLong \& Nault, D. charlesi Triplehorn \& Nault, D. guzmani DeLong \& Nault, D. gelbus DeLong, D. longulus DeLong, D. guevarai DeLong, D. elimatus (Ball), D. cimmyti Nault \& Styer e D. ebberti Nault \& Styer (Nault, 1985; 1990; Nault \& Styer, 1994; Triplehorn \& Nault, 1985).

Alguns estudos a respeito da biologia de D. maidis têm sido realizados. Em linhas gerais, à $25-26^{\circ} \mathrm{C}$ o tempo de uma geração para $D$. maidis é de $25-30$ dias. O período embrionário é de 8-9 dias, não havendo porém eclosão de ninfas em 
temperaturas inferiores a $20^{\circ} \mathrm{C}$. Após a eclosão, as ninfas se desenvolvem em 15-17 dias, passando por cinco estádios. Fêmeas adultas irão copular e iniciar a postura dos ovos em 1-2 dias após emergirem. A média de sobrevivência dos adultos é de 7-8 semanas a $26^{\circ} \mathrm{C}$, podendo alguns indivíduos chegarem a 15 semanas. As fềmeas colocam de 400 600 ovos durante toda a vida (Barnes, 1954; Marín, 1987; Tsai, 1988; Waquil et al., 1999). A cigarrinha-do-milho é capaz de completar duas gerações durante a cultura do milho, havendo um significativo aumento da população da primeira para a segunda geração (Todd et al., 1991).

\subsubsection{Distribuição geográfica e plantas hospedeiras}

A cigarrinha-do-milho pode ser encontrada praticamente em todas as regiões tropicais e subtropicais das Américas onde o milho é cultivado, desde o nível do mar até montanhas elevadas como nas Serras Mexicanas e Andes Peruanos (Nault, 1985; 1990). Entretanto, as maiores populações são encontradas em altitudes menores que 750m (Barnes, 1954). Esta ampla distribuição pelas Américas deve-se provavelmente a sua alta mobilidade e estreita associação com seu hospedeiro natural, o milho, cuja distribuição pelo continente se deu às custas de intervenção humana (Gámez, 1983; Triplehorn \& Nault, 1985). Grandes populações de D. maidis em milho têm sido relatadas desde o sul dos EUA até a Argentina, incluindo países como Brasil, Colômbia, Costa Rica, Cuba, República Dominicana, Guatemala, Jamaica, México, Nicarágua, Panamá, Peru, Porto Rico e Venezuela (Menezes, 1972; Oliveira, 1996; Oman, 1948;

Triplehorn \& Nault, 1985). No Brasil, esta espécie tem sido relatada desde 1938 em diversos estados (Costa, 1957; Mendes, 1938; Menezes, 1972; Oliveira, 1996; Silva et al, 1968).

O hospedeiro primário para $D$. maidis é o milho, porém no México e na América Central esta espécie também tem sido relatada em espécies de Tripsacum como por exemplo $T$. pilosum Scribner \& Merrill e $T$. dactyloides (L.), e também em algumas 
espécies do gênero Zea como Z. diploperennis Iltis, Z. perennis (Hitchcock), Z. mays spp. mexicana (raça chalco) e Z. luxurians (Durieu \& Ascherson), além de Euchlaena mexicana Schrad (Barnes, 1954; Nault, 1990; Nault \& DeLong, 1980; Nault et al., 1983; Tsai, 1988). No Brasil, foi relatada em plantas como batata, algodão e outras gramíneas (Costa, 1957; Mendes, 1938; Silva et al., 1968) mas ao que parece estas foram coletas acidentais, já que coletas mais extensivas têm registrado esta espécie apenas em milho, onde pode representar de 74 a 93\% das cigarninhas coletadas (Oliveira, 1996; Waquil, 1997), e sorgo (Waquil, 1997).

\subsection{2. Época de ocorrência e perdas causadas à cultura}

Adultos de $D$. maidis se estabelecem em plântulas de milho e são capazes de manter altas populações durante todo o ciclo do milho (Todd et al., 1991). São abundantes no final do verão (Gordon et al., 1985; Nault, 1985), desaparecendo do campo quando o milho amadurece (Nault, 1990). Altas densidades populacionais (mais de 30 indivíduos por planta) podem ser encontradas entre os meses de outubro e novembro na América Central, México e Caribe (Gladstone et al., 1994). No México, estudos com cartões adesivos mostraram que as maiores populações de $D$. maidis ocorrem nos meses de outubro a fevereiro (estação seca) quando se planta o milho, com coletas muito baixas de março a setembro (estação chuvosa) (Barnes, 1954; Larsen et al., 1992) e estes resultados mostraram certa sincronia entre crescimento da população de D. maidis e o desenvolvimento da cultura do milho (Todd et al., 1991). No Brasil, esta praga aparece nos plantios normais a partir de outubro, e sua população aumenta nos plantios tardios (Fernandes \& Balmer, 1990; Silva et al., 1991). Na região de Sete Lagoas/MG, o pico populacional desse inseto se dá nos meses de março e abril, aumentando a possibilidade da ocorrência do enfezamento do milho safrinha (Waquil, 1997). No entanto, esta espécie tem sido coletada em milho em diversas regiões do país, independente da época do ano (Oliveira, 1996). 
A cigarninha-do-milho é considerada uma das mais sérias pragas do milho na América Latina, e seu status de praga se deve a sua capacidade de transmitir, de forma persistente e propagativa, o vírus da risca do milho ("maize rayado fino virus"-MRFV) e dois molicutes associados ao enfezamento do milho, Spiroplasma kunkelii Whitcomb et al. ("corn stunt spiroplasma"-CSS) e o fitoplasma do milho ("maize bushy stunt phytoplasma"-MBSP) (Nault, 1980; 1990). Em muitas regiões, as perdas ocasionadas pela incidência de doenças transmitidas por $D$. maidis podem ser esporádicas. Entretanto, os danos podem ser bastante severos em áreas cultivadas com variedades suscetíveis e, em especial, onde o milho é cultivado durante todo o ano, principalmente se as plantas forem infectadas ainda no estágio de plântula. Desde o sul dos EUA e em toda a América Latina, em países como México, El Salvador, Nicarágua e Peru, são registradas relevantes quebras de produção que, em alguns casos, podem chegar a $100 \%$ (Gámez \& León, 1985; Nault,1990; Nault \& Bradfute, 1979; Nault et al., 1981).

No Brasil, as doenças do milho associadas a vírus e molicutes transmitidas por D. maidis eram consideradas de pouca importância (Kitajima \& Nazareno, 1985; Kitajima et al., 1984). No entanto, nos últimos anos a incidência dos enfezamentos do milho aumentou consideravelmente na região Centro-Sul, especialmente em plantios tardios (Fernandes \& Balmer, 1990; Silva et al., 1991). Existem diversos relatos de incidências elevadas dos enfezamentos e MRFV, e perdas expressivas de produção, principalmente nos Estados de São Paulo, Minas Gerais, Goiás e Paraná (Folegatti et al., 1997; Oliveira et al., 1998; Waquil et al., 1996), tornando-se enfermidades de grande importância econômica. Visando caracterizar os danos causados pelo complexo enfezamento na cultura do milho, Massola Júnior et al. (1999) trabalhando com dois híbridos suscetíveis Dina 933e e XI-510, observaram que para cada $1 \%$ na incidência dos enfezamentos há um dano na produção de $0,8 \%$ para ambos os híbridos e de $0,8 \mathrm{e}$ $0,4 \%$ no peso de 1.000 grãos para Dina 933 e e XL-510, respectivamente, mostrando que essas enfermidades são capazes de provocar perdas quantitativas relevantes à cultura do milho. No Triângulo Mineiro e Goiás, foram observadas altas incidências dos enfezamentos pálido e vermelho, que ocasionaram perdas expressivas de até $100 \%$ da produção. A constatação da suscetibilidade de muitos dos híbridos comerciais ao 
complexo enfezamento no Brasil, indicam a necessidade de busca de alternativas para o controle destas doenças (Oliveira et al., 1998).

\subsubsection{Possíveis estratégias de sobrevivência de $D$. maidis na entressafra do milho}

D. maidis desaparece dos campos de milho quando estes amadurecem (Nault, 1990), não tendo esta espécie o mesmo comportamento que uma congênere sua, $D$. elimatus, que utiliza plantas do gênero Bromus L. ou outras plantas herbáceas que crescem ao longo de cursos d'água durante a entressafra (Barnes, 1954; Nault, 1985). Nault (1990) sugeriu que as populações desta cigarrinha devem entrar em diapausa em áreas próximas ou migrar para áreas de baixa altitude no México onde entrariam em diapausa ou que estas se deslocariam para áreas de milho irrigado onde estabeleceriam suas populações. Muitos insetos utilizam a diapausa como alternativa para escaparem de condições desfavoráveis (Denlinger, 1986; Masaki, 1980) como por exemplo a ausência da planta hospedeira. No entanto, a possibilidade de que a cigarrinha-do-milho entre em diapausa já foi descartada, assim como a permanência em restos culturais (Larsen et al., 1992).

Migração e dispersão parecem ser comportamentos especialmente importantes para ciganinhas que utilizam um hospedeiro tão impermanente como o milho (Nault, 1990) e esta tem sido apontada como a estratégia mais provável para a sobrevivência da cigarrinha-do-milho durante a entressafra do milho. Estudos de laboratório mostraram que cigarrinhas do gênero Dalbulus que são especialistas em milho, como $D$. maidis, apresentaram maior resposta de fuga através do vôo do que as espécies que se alimentam em plantas perenes, e uma vez que, uma maior resposta de fuga pode ser uma medida da tendência migratória, esta parece ser uma estratégia utilizada por D. maidis (Heady \& Nault, 1985). Larsen et al. (1992) em coletas de campo com cartões adesivos e estudos de laboratório da capacidade de sobrevivência da cigarrinha-do-milho na ausência de alimentação e/ou água, hipotetizaram que esta espécie possa sobreviver na entressafra 
em hábitats adjacentes aos campos de milho, utililizando para isto apenas água, sendo portanto um migrante local.

D. maidis parece também ser dotada de capacidade de migração a longas distâncias. A epidemia de enfezamento pálido ocorrido na Flórida em 1979 tem sido atribuída a populações desta cigarrinha que provavelmente vieram das ilhas do Caribe através do furacão David (Bradfute et al., 1981). Taylor et al. (1993) estudaram a atividade de vôo de D. maidis e outras espécies do gênero, em condições que simulavam diferentes estações do ano no México Central, diferentes fotoperíodos e idade da planta hospedeira. O comportamento de vôo desta cigarrinha foi consistente com vôos migratórios de inverno, os quais coincidem com o fim da safra do milho e com correntes de ventos ("El Norte"). Estes autores sugeriram que estas correntes de vento poderiam levar as populações de D. maidis do México Central, onde o inverno é seco e com baixas temperaturas, para a Costa do Golfo onde o milho de inverno é cultivado, e o caminho inverso seria realizado pela corrente de vento denominada Zona de Convergência InterTropical, o que explicaria o aparecimento súbito destas cigarrinhas em plântulas de milho no início da estação chuvosa.

Se pouco se sabe sobre a(s) estratégia(s) de sobrevivência de $D$. maidis na entressafra do milho, pouco também se conhece sobre a sobrevivência dos patógenos por ela carregados (Nault, 1990; Larsen et al., 1992). Alguns estudos têm demonstrado que a íntima associação entre $D$. madis e os patógenos por ela transmitidos, notadamente $S$. kunkelii, pode resultar em mútuo benefício para vetor e patógeno (Ebbert \& Nault, 1994; Madden \& Nault, 1983; Nault, 1990). Em estudos com espécies de Dalbulus, observouse que $D$. maidis foi a única espécie que não teve a sua sobrevivência e fecundidade afetada por infecção com S. kunkelii; no entanto, isto ocorreu em relação ao fitoplasma, principalmente entre 20 e $29^{\circ} \mathrm{C}$ (Madden \& Nault, 1983; Madden et al., 1984). Ebbert \& Nault (1994) investigaram a hipótese de que $S$. kunkelii poderia aumentar a capacidade de sobrevivência de $D$. maidis em condições que simulavam o inverno e ausência da planta hospedeira. Cigarrinhas infectadas com S. kunkelii tiveram sua sobrevivência aumentada em temperaturas entre 10 e $20^{\circ} \mathrm{C}$, sendo que este aumento foi mais pronunciado nas fềmeas, porém em temperaturas abaixo de zero este efeito não foi 
observado (Ebbert \& Nault, 1994). Assim, esta associação de mútuos benefícios entre $D$. maidis e $S$. kunkelii, parece desempenhar um importante papel na estratégia de sobrevivência de ambos, hospedeiro e patógeno, na entressafra do milho (Ebbert \& Nault, 1994; Nault, 1990).

\subsection{Migração em insetos}

A migração é um importante componente do ciclo de vida de muitos organismos. Não somente por permitir que estes escapem de condições desfavoráveis, mas também, por permitir a exploração de hábitats criados por sucessivas ou estacionais alterações ambientais. $\mathrm{O}$ migrante pode assim fazer uso de recursos no espaço e no tempo e determinar através deste comportamento onde e quando se reproduzir (Dingle, 1985a). Os insetos apresentam pelo menos duas grandes vantagens como objeto para estudos dos mecanismos e do significado adaptativo da migração. A primeira seria o tamanho reduzido o que facilita a criação de um grande número de indivíduos em laboratório. Estudos de laboratório sobre a fisiologia e comportamento podem assim serem comparados com os movimentos, ciclos sazonais, dinâmica populacional, o que permite uma melhor compreensão do fenômeno. A segunda vantagem é a sua grande diversidade taxonômica, que vem acompanhada de uma enorme diversidade de modos de migração. Existem relatos de alguns ortópteros e lepidópteros, e outros relativamente grandes insetos, que empreendem vôos continentais e mesmo intercontinentais. Porém, mais comum e não menos importante é a migração empreendida por inúmeros diminutos insetos como os afideos, que movem-se por uma centena ou poucas dezenas de metros (Dingle, 1985b; Kennedy, 1985).

Antes de mais nada é necessário fazer uma distinção entre termos que muitas vezes são empregados como sinônimos, "dispersão" e "migração". A dispersão é um fenômeno caracterizado pelo aumento da distância média entre indivíduos, e isto é algo 
que pode ocorrer somente em uma população. No entanto, a migração é um movimento para além do hábitat, e é algo que um indivíduo pode fazer (Southwood, 1981).

Um fenômeno tão complexo como a migração só pode então ser compreendido através de uma visão multidisciplinar, que envolve estudos nos campos da genética, bioquímica, fisiologia e comportamento, ecologia pura e aplicada, computação e modelagem, meteorologia e climatologia (Gatehouse, 1997). Por exemplo, o fato de um indivíduo deslocar-se de um lugar para outro tem um significado ecológico, no entanto, o motivo que o levou a fazê-lo é ecológico ou comportamental. Já o movimento físico durante a migração é um aspecto anatômico e fisiológico, e por fim, as conseqüências deste movimento para o indivíduo e sua espécie é assunto para a evolução (Taylor, 1985).

Durante o curso dos anos muitos autores têm proposto definições para o fenômeno migração sobre os mais diversos aspectos (Dingle, 1980; Johnson, 1963; 1969; Kennedy, 1961; Southwood, 1962; 1971; Taylor \& Taylor, 1983), porém por se tratar de um assunto que envolve uma enorme diversidade de organismos e particularidades, nenhuma delas é totalmente satisfatória, já que muitas vezes são baseadas em casos específicos, existindo então um sem número de exceções. A compreensão do assunto migração não é tarefa fácil, já que a mesma dependerá das características do organismo em estudo, como o seu tamanho, o modo e meio pelo qual se locomove, estratégia de vida dentre outras (Kennedy, 1985).

Para alguns insetos a migração pode estar associada a diapausa. Alguns autores consideram a diapausa como tendo a mesma função ecológica que a migração, e esta poderia ser considerada uma "migração no tempo", sendo ambas adaptações para se enfrentar condições adversas (Dingle, 1972; Taylor \& Taylor, 1977). Portanto, comportamentos como migração e diapausa podem sincronizar a reprodução com condições favoráveis de disponibilidade de recursos no espaço e no tempo (Southwood, 1977). Em outros casos uma ou outra pode ocorrer, geralmente a migração ocorre quando as alterações ambientais são assincrônicas, por outro lado as alterações sincrônicas do ambiente podem favorecer a diapausa (Solbreck, 1985). 


\subsubsection{Migração por correntes de ventos}

O fenômeno dos insetos utilizarem correntes de vento existentes em grandes altitudes, tem sido observado em diferentes taxa, envolvendo insetos de todos os tamanhos, desde diminutos como cigarninhas até os grandes insetos como gafanhotos e mariposas, sendo que Hemiptera, Orthoptera e Lepidoptera tem sido os grupos mais estudados (Gatehouse, 1997). O deslocamento dos insetos através destas correntes de ar depende muito das condições atmosféricas, que podem diferir radicalmente entre o dia e a noite. Principalmente em dias claros, há o aquecimento do solo e a formação de correntes de convecção resultando numa circulação vertical do ar, e estas correntes auxiliam os insetos na rápida ascensão para altitudes onde possam ser transportados pelo vento. No entanto, com o cair da noite, os ventos verticais cessam, e os migrantes que decolam após este período voam pelo seu próprio esforço a altitudes de 100-2.000 m, onde ventos muito rápidos podem carregá-los a longas distâncias (Drake \& Farrow, 1988). O potencial para deslocamentos através dos ventos de grandes altitudes é substancialmente maior a noite do que de dia, e as espécies que necessitam migrar por distâncias apreciáveis em escala geográfica, geralmente utilizam a migração noturna (Riley et al., 1995).

A decisão de decolar, em migrantes diurnos, parece envolver fatores endógenos do inseto associado a fatores ambientais (especialmente temperatura, vento e chuva), e estes apresentam fototaxia positiva (Blackmer \& Byme, 1993). Em insetos de migração noturna, a decolagem se dá geralmente pouco após o crepúsculo, associado à baixa intensidade luminosa e também a temperatura (Dreisig, 1980). A decolagem pode ser inibida por baixas temperaturas, ventos fortes e chuva (Riley et al., 1987; Riley et al., 1995), portanto temperaturas elevadas e ausência de precipitação são essenciais para o início e manutenção do vôo migratório (Carlson et al., 1992). Logo após a decolagem temos um rápido vôo ascendente, que pode chegar a velocidades de até $1,5 \mathrm{~m} / \mathrm{s}$ como em Helicoverpa zea (Boddie) (Lingren et al., 1995). A altura de vôo dos insetos de migração diurna depende muito da temperatura, ou seja, do limiar de temperatura para a atividade 
de vôo. A atividade de vôo cessa e o inseto desce quando encontra uma temperatura abaixo do seu limiar de temperatura para o vôo, e a densidade de insetos decresce com a altitude (Drake \& Farrow, 1988). Em insetos de migração noturna a altitude alcançada depende do comportamento do inseto. Em vôos de curta duração Nilaparvata lugens Stål e outros delfacídeos podem voar em temperaturas abaixo do seu limiar de vôo (Riley et al., 1987). A freqüência de ocorrência, o conhecimento das condições atmosféricas e alta incidência de orientação coletiva durante a migração, sugerem que os migrantes noturnos são os mais adaptados. A orientação no vôo é dada pelo ângulo formado entre direção de orientação e a direção do vento, que geralmente é menor que $90^{\circ}$. Muitos insetos promovem um alinhamento mútuo com a direção do vento, uma vez que na migração para longas distâncias a chance de se encontrar um coespecífico de outra origem para a reprodução é pequena, este alinhamento promove um aumento de chance de indivíduos chegarem juntos em determinado local e se reproduzirem (Drake, 1983; Riley et al., 1995).

Os vôos podem ter curta duração ou se estenderem por horas ou mesmo por toda noite (Riley et al., 1987). Os fatores que determinam o fim da migração podem ser baixas temperaturas, precipitação, localização do hábitat adequado, diminuição do suprimento de energia, estado neurofisiológico, inibição do vôo por intensidade luminosa ou a combinação de ambos (Carlson et al., 1992; Pedigo, 1989). Para muitos insetos, durante o vôo, o contraste entre o comprimento de onda emitido por áreas vegetadas e por áreas onde o solo está exposto pode ter papel importante na decisão de pousar em busca da planta hospedeira, interrompendo a migração (Prokopi \& Owens, 1983).

A grande vantagem do uso dos ventos como veículo de transporte é a possibilidade de deslocamento a distâncias infinitamente maiores do que as alcançadas pelo próprio esforço de vôo, e a despeito do fato dos insetos precisarem estar batendo as asas constantemente durante o trajeto, o custo energético tem um impacto negligenciável na reprodução após a migração (Gunn \& Gatehouse, 1993). O estudo das condições meteorológicas juntamente com fatores biológicos, tais como época do ano em que o inseto está propício a migrar; se este voa de dia, de noite ou ambos; temperatura mínima 
para o vôo; altura de vôo; dentre outros, podem ser usados para prever as condições mais adequadas para a migração de insetos de importância econômica (Carlson et al., 1992).

\subsubsection{Exemplos de comportamento migratório em insetos}

A cigarninha-do-milho tem sido alvo de suspeitas a respeito de sua capacidade de migração a longas distâncias, como exemplo, temos a epidemia de "corn stunt spiroplasma" no sul da Flórida em 1979, que provavelmente foi devido a cigarninhas que vieram das Ilhas do Caribe (Bradfute et al, 1981). Procurando relacionar a atividade de vôo com inferências para a migração, Taylor et al. (1993) realizaram estudos com três espécies do gênero Dalbulus. Para D. maidis, a atividade de vôo foi altamente crepuscular nas condições de verão, o que é uma adaptação comportamental para vôos locais, pois as condições atmosféricas são mais estáveis, o que favorece a busca da cópula, e de outras plantas, sem o risco de serem carregadas para longe da fonte de recursos. Por outro lado, o meio da manhã é o período de maior instabilidade atmosférica, o que permitiria a ascensão das cigarninhas e o encontro com ventos que poderiam carregá-las por longas distâncias. Em condições de outono as cigarrinhas permaneceram com vôos crepusculares mas houve um incremento nos vôos da manhã $\mathrm{e}$ no inverno estes foram os vôos predominantes. Neste mesmo estudo observou-se que o comportamento de vôo de $D$. maidis está condicionado pelos níveis de luz e que em fềmeas está também relacionado com a condição da planta hospedeira. Estes autores teorizaram que D. maidis utiliza ventos direcionados para o Golfo do México ("El Norte") com a chegada do inverno, já que em laboratório o comportamento de vôo foi condizente com estas condições atmosféricas, uma vez que nesta região o milho é plantado com irrigação no inverno e primavera, e retornam ao sul dos EUA pelos ventos no verão (Zona de Convergência Inter-Tropical). No entanto, Larsen et al. (1992) baseado em coletas com cartões adesivos, e estudos de laboratório da capacidade de sobrevivência de $D$. maidis, e algumas de suas congêneres, na ausência da planta 
hospedeira e em condições que simulavam a estação chuvosa e seca no México, sugeriram que $D$. maidis é um migrante local. Esta cigarrinha abandonaria a cultura do milho no final da safra, início da estação seca, podendo sobreviver neste período em hábitats adjacentes apenas com água, voltando aos campos de milho na estação chuvosa, logo após o plantio da nova safra do milho.

A cigarrinha Empoasca fabae (Harris) é uma importante praga de diversas culturas no leste e meio oeste dos EUA (Hogg, 1985). Esta cigarrinha não sobrevive as baixas temperaturas do inverno nestas regiões e passa esta estação do ano no extremo sul do país. Alguns trabalhos, no entanto, têm mostrado que esta espécie pode sobreviver ao inverno em pinheiros na região norte. Quando se encontra no sul, durante o inverno, esta cigarninha atinge um grande crescimento populacional em meados de abril e começo de maio, quando então migram de volta para o leste e meio oeste dos EUA. O estímulo para a migração é a diminuição do suprimento de alimento com a maturação e colheita das plantas hospedeiras, principalmente hortaliças e legumes, associada com condições atmosféricas (Pienkowiski \& Medler, 1964). Carlson et al. (1992) investigaram o movimento de migração de $E$. fabae e concluíram que a distância de aproximadamente $1.000 \mathrm{~km}$, no caso estudado, foi coberta em um vôo contínuo de $24-36 \mathrm{~h}$, ou dois ou três sucessivos vôos noturnos, e a terminação deste vôo era causada por precipitação, diminuição das reservas de energia e abaixamento de temperatura.

$N$. lugens é uma cigarrinha que tem origem tropical, porém, em região temperada não consegue sobreviver a baixas temperaturas e a perda de sua planta hospedeira durante o inverno. Grandes infestações têm ocorrido no leste da Ásia, norte da China e Japão, por vôos migratórios de longas distâncias iniciados por estas cigarrinhas de regiões tropicais e subtropicais da Ásia onde estas passam o inverno, o que possibilita que explorem vastas regiões de plantio de arroz durante todo o verão, e os prejuízos causados por estas cigarrinhas podem chegar a 400 milhões de dólares anuais. Este movimento que pode chegar de 750 a $1.200 \mathrm{~km}$, é realizado com auxílio de correntes aéreas que no verão sopram no sentido sudoeste e oeste da Ásia, havendo evidências de vôos de retorno no outono através de ventos que sopram para o sul (Holt et al., 1996). De acordo com Wu et al. (1994) a proporção de braquípteros e macrópteros 
em $N$. lugens é um importante indicador da propensão da população para migrar, esta proporção por sua vez é dada em função da qualidade nutricional do hospedeiro. Durante a safra do arroz a maioria da população é composta por indivíduos braquípteros. $\mathrm{Na}$ senescência, com o decréscimo de aminoácidos essenciais como leucina e alanina, aumenta-se muito o número de indivíduos macrópteros os quais irão promover a migração. Ao estabelecerem-se em uma área, ao longo das gerações o número de braquípteros passa a ser maioria, só havendo uma reversão deste quadro no final da safra.

As vantagens do vôo para o escape de condições desfavoráveis e colonização de novos hábitats são óbvias, mas qual a vantagem da redução ou ausência das asas, que forçam o inseto a permanecerem sedentários? A vantagem é que com a ausência ou redução das asas e dos músculos de vôo, mais energia pode ser canalizada para a reprodução, e a ocorrência de histólise de músculos de vôo após a migração é congruente com isto. Estes benefícios reprodutivos podem ser comprovados pelo fato de que indivíduos com asas menores são mais fecundos e se reproduzem mais cedo (Zera, 1985). Assim, o polimorfismo de asas é uma síndrome de características resultando em "morfos" que são adaptados para a reprodução/sedentarismo versus diapausa/migração (Dingle, 1982).

Para a cigarrinha Prokelisia marginata (Van Duzze), estudada por Denno (1985), a maior fecundidade dos braquípteros em relação aos macrópteros não foi clara, como já havia sido relatado para pulgões (Dixon, 1972), porém diferença significativa foi observada no que tange ao período de pré-oviposição, que em braquípteros foi bem menor, e também a idade em que fềmeas iniciaram a reprodução. Outra observação foi de cunho comportamental, notou-se que indivíduos macrópteros eram mais "ativos" que os braquípteros, abandonando a planta hospedeira ao menor distúrbio. Portanto, estas duas características, imobilidade e início de reprodução mais cedo, levam a uma melhor exploração dos recursos oferecidos pela planta hospedeira por parte dos braquípteros em relação aos macrópteros. $\mathrm{O}$ fato das grandes explosões de populações desta cigarrinha $\mathrm{e}$ sérios danos estarem relacionados com indivíduos braquípteros é consistente com esta hipótese (Denno, 1985). Neste mesmo estudo, esse autor observou que a resposta 
migratória, ou seja a produção de indivíduos macrópteros propensos ao vôo, era mais dependente da condição nutricional da planta hospedeira do que da densidade populacional, sendo os indivíduos macrópteros altamente capazes de distinguir, em campo, plantas hospedeiras melhor nutridas o que resultaria em uma descendência maior e mais fecunda. A produção de indivíduos alados e braquípteros na cigarrinha $P$. marginata, com relação a qualidade da planta hospedeira, também foi estudada por Denno et al. (1980), que observaram que este dimorfismo de asas não era devido a uma simples regra genética. As condições ambientais as quais o estágio ninfal é submetido, e aqui se inclui a qualidade nutricional da planta hospedeira, guia os mecanismos que selecionam o aparecimento de asas ou não. Assim, estudos de laboratório mostraram que ninfas de $P$. marginata submetidas a uma alimentação de baixa qualidade dão origem a indivíduos macrópteros e a abundância destes em plantas de alto valor nutritivo e a rara presença em plantas pobres em nutrientes é resultado da migração.

Outro aspecto importante notado para cigarninhas em relação à planta hospedeira, foi observado por Teraguchi (1986), em estudos realizados com armadilhas adesivas e de sucção. Cigarrinhas associadas com plantas perenes seriam menos propensas a migração do que aquelas associadas com plantas anuais. Todos os cicadelídeos que apresentaram comportamento não migratório estavam associados a plantas perenes, e cigarrinhas associadas a plantas anuais amplamente distribuídas parecem ser migratórias. A classificação das 23 espécies de cicadelídeos coletadas, quanto ao status de migrante ou não-migrante, foi baseada em diversos aspectos, como o comportamento de vôo, ou seja a altura nas quais os mesmos foram capturados, status reprodutivo de fềmeas (Síndrome oogênese-vôo) e relação braquípteros/macrópteros ou a combinação de ambos (Teraguchi, 1986). Isto nos mostra que o entendimento do processo de migração requer uma visão mais globalizada dos aspectos que o envolvem.

A persistência do hábitat tem sido identificada como um fator crítico para a evolução da migração e do dimorfismo de asas em insetos (Denno \& Roderick, 1990; Harrison, 1980). Em insetos, as asas tem diversas funções como, a busca da cópula, localização de hábitat para alimentação, desenvolvimento ou diapausa. Denno et al. (1991) estudaram diversas espécies de cigarrinhas (Delphacidae), que apresentavam 
dimorfismo de asas, quanto a influência da densidade populacional e persistência do hábitat na expressão ou não de asas. Estes autores concluíram que para estas cigarrinhas a necessidade de asas para a busca da cópula é inversamente proporcional a densidade da população. No entanto, em relação a deterioração do hábitat esta é positivamente correlacionada, pois as asas são a melhor forma de escape desta condição. Em muitas espécies de cigarninhas em hábitats persistentes onde a cópula, mesmo sob baixos níveis populacionais, é obtenível, a maioria dos machos são braquípteros, enquanto que indivíduos da mesma espécie em hábitat temporário são macrópteros. Assim, a duração da estabilidade do hábitat e redução na disponibilidade para cópula, tem favorecido aos altos níveis de migração (macrópteros) em hábitats temporários. Em estudos com seis espécies de cigarrinhas do gênero Dalbulus, Heady \& Nault (1985) observaram que as espécies associadas a hospedeiros anuais, ou seja um hábitat mais instável, apresentaram maior resposta de fuga por vôo, do que aquelas que se alimentavam em plantas perenes. Assim a migração é provavelmente uma característica comportamental de espécies de Dalbulus, que como D. maidis, utilizam hospedeiros de crescimento estacional, uma vez que a resposta de fuga pode ser também uma medida da tendência migratória.

Os pulgões são conhecidos como sérias pragas de muitas culturas. Muito se comenta a respeito de sua capacidade de dispersão aérea, que segundo Hardie (1989) a curta ou a longa distância é regida por estímulos visuais. A proporção de indivíduos alados e ápteros é influenciada pela condição de agregação no estágio ninfal que influencia o desenvolvimento de asas, musculatura de vôo, acúmulo de reservas e desenvolvimento de gônadas (Dixon \& Howard, 1986). O estímulo para que os pulgões iniciem o vôo é uma resposta fototática positiva de adultos tenerais a curtos comprimentos de onda $(<500 \mathrm{~nm})$ emitidos pelo céu, gradualmente, durante o vôo os comprimentos de ondas maiores tomam-se mais atrativos (> $500 \mathrm{~nm}$ ) como os exibidos pelos vegetais, então eles cessam o vôo e descem sobre as plantas (David \& Hardie, 1988). Além da luminosidade, outro fator importante é a temperatura (Dry \& Taylor, 1970; Halgren \& Taylor, 1968). Evidências existem de que sobre certas condições, os afideos podem imprimir vôos de longas distâncias, centenas de quilômetros sobre desertos e oceanos. Tem-se argumentado que esta seja uma estratégia de colonização de 
áreas distantes, no entanto, a proporção do sucesso deste procedimento é desconhecido (Hardie, 1989). Porém, Loxdale et al. (1993) propuseram que os movimentos a curtas distâncias tem um maior impacto na população e na distribuição de genótipos do que os movimentos a longas distâncias que são infreqüentes.

O fenômeno da migração é um assunto extremamente complexo, sendo encontrado nos mais diversos organismos, desde diminutos insetos até aves, peixes e grandes mamíferos. Dentro da classe insecta, no entanto, encontramos uma enorme diversidade no modo e na escala da migração, que fornecem, sem dúvida, uma substancial gama de exemplos para o estudo deste fenômeno. Sabendo desta complexidade, de maneira alguma a migração pode ser encarada ou definida simplesmente sob o aspecto da fisiologia, ecologia, comportamento ou mesmo da genética, evolução dentre outras, pois é um fenômeno multidisciplinar, mostrando em cada um dos casos em que se estuda diferentes nuances destas diferentes áreas de estudo. A migração constitui-se num dos mais complexos e eficientes mecanismos utilizados pelos insetos para contornar as adversidades impostas pelo ambiente, como as condições climáticas desfavoráveis, ausência de plantas hospedeiras, competição intra e interespecífica, dentre outras, e esta habilidade de se dispersar dos insetos é também responsável pela ampla distribuição dos seus genes. Desta maneira, a migração não pode ser vista como um evento estanque dentro da história de vida dos insetos e sim como uma tentativa de sobrevivência e perpetuação da espécie. Portanto, o conhecimento mais profundo da migração em insetos poderá fornecer subsídios para um melhor entendimento do ciclo de vida dos mesmos e isto permitirá, no caso dos insetos considerados pragas, o delineamento de medidas preventivas de controle.

\subsection{DNA polimórfico amplificado a o acaso (RAPD-PCR)}

Marcadores eletroforéticos são poderosas ferramentas que têm facilitado o estudo de diversas áreas da biologia, pura ou aplicada, cobrindo questões de filogenia, 
evolução, ecologia e dinâmica de populações (Symondson \& Liddell, 1996). Inicialmente, técnicas com o uso de proteínas, especialmente aloenzimas, eram as mais empregadas, atualmente a aplicação desta técnica tem sido superada por aquelas baseadas em DNA (Avise, 1994). O campo da biologia molecular tem se expandido grandemente nos últimos anos e muitos entomologistas tem desejado utilizar esta ferramenta, já que esta trás um novo nível de resolução para estudos de ecologia e taxonomia de insetos (Loxdale \& Lushai, 1998) dentre outros.

A técnica da reação da polimerase em cadeia ("Polimerase Chain Reaction" PCR) (Saiki et al., 1988), um método que gera uma exponencial e seletiva amplificação de um fragmento de DNA, pode ser usada para detecção e diferenciação de um grande número de organismos. Todavia, requer o prévio conhecimento da seqüência de bases para a confecção de dois primers, o que muitas vezes requer um substancial investimento de tempo e recursos (Cenis et al., 1993). Por outro lado, a técnica de DNA polimórfico amplificado ao acaso ("Random Amplified Polymorphic DNA" - RAPD ou "Arbitrarily primed PCR - AP-PCR") (Welsh \& McClelland, 1990; Willians et al., 1990), uma técnica molecular baseada na PCR, utiliza um único primer com $\approx 10$ nucleotídeos de comprimento de seqüência arbitrária, que anela-se em regiões arbitrárias do genoma e sintetiza múltiplos produtos de amplificação, detectando polimorfismo na ausência de informação específica da seqüência de nucleotídeos do DNA molde (Willians et al., 1990). O primeiro passo para a utilização desta técnica refere-se a seleção dos primers a serem utilizados, cuja escolha deve basear-se na seguinte ordem: revelar diferenças, produzir bandas bem definidas e fornecer um padrão reproduzivel (Loxdale et al., 1996).

O RAPD-PCR é capaz de detectar a alteração de uma única base no DNA genômico, uma vez que a alteração em uma única base do primer gera produtos de amplificação totalmente diferentes, uma alteração em uma base do genoma pode levar a não amplificação de determinado fragmento. Mas isto não implica, no entanto, que todas as amplificações são resultado do perfeito pareamento entre o primer e o DNA molde (Williams et al., 1990; Thormann et al., 1994). Ponto importante refere-se ao comprimento e proporção dos nucleotídeos $\mathrm{G}+\mathrm{C}$ dos primers na amplificação gerada por 
RAPD-PCR. O mínimo comprimento para o primer são nove bases e a proporção mínima de $\mathrm{G}+\mathrm{C}$ em cada primer para gerar níveis detectáveis de amplificação é de $40 \%$ ou superior (Williams et al., 1990). As fontes de polimorfismo para marcadores RAPDPCR podem incluir deleções no sítio de anelamento do primer com o DNA genômico, inserções entre os sítios de anelamento dos primers colocando-os a uma distância maior do que aquela suportada pela PCR ou inserções que alterem o tamanho do segmento de DNA sem prevenir a amplificação (Willians et al., 1990). Marcadores moleculares do tipo RAPD-PCR comportam-se como dominantes, ou seja, não é possível distinguir se o segmento de DNA amplificado provém de um loco heterozigoto (1 cópia) ou homozigoto (2 cópias) (Carlson et al., 1991; Williams et al., 1990).

A técnica de RAPD-PCR oferece diversas vantagens sobre outros métodos para estudo de variabilidade genética. Um ilimitado número de marcadores RAPD-PCR podem ser gerados, ao contrário do que ocorre com marcadores isoenzimáticos que são limitados a poucas regiões do genoma e um limitado número de sistemas enzimáticos podem ser utilizados, além do fato de que um vasto número de primers RAPD-PCR podem ser sintetizados para análise de uma ampla variedade de espécies (Cenis et al., 1993; Williams et al., 1990); nenhum trabalho preliminar é requerido, como o isolamento de sondas clonadas de DNA, preparação de filtros para hibridização; marcadores RAPD-PCR podem simplificar a transferência de informação entre pesquisadores e é um método que permite automação (Williams et al., 1990). Com relação a técnica chamada polimorfismo no comprimento de fragmentos de restrição (Restriction Fragment Lenght polimorphisms - RFLP) (Grodzicker et al., 1974), RAPDPCR apresenta como vantagens a rapidez, simplicidade e a não utilização de materiais radioativos e equipamentos caros (Cenis et al., 1993) além de gerar um número maior de marcadores (Williams et al., 1990). No entanto, marcadores RFLP parecem ser mais confiáveis do que RAPD-PCR para comparações interespecíficas, o que também parece ser verdadeiro para casos de comparação intraespecífica que envolvam populações muito distintas (Thormann et al., 1994). Como desvantagens do método temos que em estudos filogenéticos não é possível distinguir a origem genômica (nuclear ou citoplasmática) dos fragmentos, a homologia das seqüências das bandas com mesma 
mobilidade no gel não é conhecida (Thomann et al., 1994; Tingey \& Tufo, 1993) não sendo possível dizer se bandas com mesmo peso molecular entre dois indivíduos representariam um caráter homólogo (herdado de um ancestral comum) ou homoplástico (caráter que se desenvolveu independentemente dentro da população) (Pornkulwat et al., 1998), não é possível distinguir alelos heterozigotos dos homozigotos (Carlson et al., 1991; Williams et al., 1990), são requeridas outras técnicas para a obtenção de dados Mendelianos (Loxdale \& Lushai, 1998) e a reproducibilidade do método pode ser influenciada pela enzima Taq DNA polimerase utilizada, quantidade de $\mathrm{MgCl}_{2}$, qualidade do DNA, o tipo de termociclador e método de extração (Cenis et. al, 1993; Loxdale \& Lushai, 1998; Loxdale et al., 1996; Suazo et al., 1998).

RAPD-PCR é uma técnica simples, que requer pequenas quantidades de material biológico (Chan et al., 1999), o que é uma grande vantagem quando se trabalha com insetos muito pequenos (Loxdale et al., 1996), sendo eficiente na detecção de polimorfismo (Lin et al., 1999). É capaz de discriminar indivíduos de uma população, populações ou clones de uma espécie ou espécies de um gênero (Cenis \& Beitia, 1994; Guirao et al. 1997). Pode ser aplicado a espécimes de insetos conservados por longos períodos, e é um método eficiente para se obter marcadores genéticos intraespecíficos sem qualquer conhecimento prévio de informações sobre a seqüência do DNA da espécie em estudo (Margaritopoulos et al., 1998). Tem sido utilizada em estudos de estrutura genética de populações (Infante-Malachias, 1999; Lin et al., 1999), para distinguir clones e biótipos em Auchenorrhyncha (Black et al., 1992; Cenis et al., 1993; Quintero et al., 1998), na direta evidência de fluxo gênico entre populações (Hoole et al., 1999), na deteç̧ão de espécimes puros em relação aqueles onde houve introgressão genética (DeVerno et al., 1998), em mapeamento genético (Hunt \& Page, 1995; Laurent et al., 1998), na deteç̧ão da origem geográfica de populações (Puterka et al., 1993; Reyes \& Ochando, 1998), em taxonomia (Cenis \& Beita, 1994), dentre outras áreas. 


\subsubsection{Utilização da técnica de RAPD-PCR em Entomologia}

Dentre as várias técnicas moleculares atualmente utilizadas em estudos biológicos, a técnica de RAPD-PCR tem tido grande impacto em entomologia (Loxdale \& Lushai, 1998; Loxdale et al., 1996), mostrando-se como uma importante ferramenta na análise de variabilidade genética em insetos (Haymer, 1994). Um extenso número de estudos tem sido realizados com os mais diversos grupos de insetos e nas mais variadas áreas.

Skinner \& Camacho (1995) estudaram a diversidade genética dentro de uma população da cigarrinha $E$. fabae e observaram um alto grau de heterogeneidade genética nesta espécie. Os campos de alfafa têm uma gama muito grande de genótipos individuais e esta praga tem superado os esforços da resistência de plantas. Isto provavelmente ocorreu pois $E$. fabae tem sido capaz de manter altos níveis de heterozigose em muitos locos através de acasalamentos ao acaso, conseguindo manter esta variabilidade genética por gerações durante o crescimento da cultura.

A forma de reprodução tem influência na estrutura genética das populações dos insetos. Puterka et al. (1993) relataram que em clones partenogenéticos de Diuraphis noxia (Mordvilko) a descendência não diferia geneticamente de suas mães. Estes mesmos autores observaram pouca variação intrapopulacional em $D$. noxia de indivíduos coletados no campo e não pertencentes a um mesmo clone, no entanto, a técnica de RAPD-PCR foi capaz de uma boa discriminação entre as populações. A ausência de variação genética dentro das populações poderia ser atribuída ao tipo de reprodução e efeito fundador, ou seja, os poucos genótipos que chegam em uma área, rapidamente dominariam este nicho através do seu bem desenvolvido mecanismo de migração pelo vôo e reprodução partenogenética (Puterka et al., 1993). Não foi encontrada relação entre a distância geográfica e a distância genética nas populações de D. noxia dos EUA, o que provavelmente estaria mais em função do estabelecimento ao acaso de clones através do comércio do que através da migração (Puterka et al., 1993). Ausência de relação entre origem geográfica e padrão RAPD-PCR para afideos também 
foram encontradas por Cenis et al. (1993). No entanto, o polimorfismo genético permite a identificação da origem de populações de insetos recentemente introduzidas (Powell et al., 1980). Puterka et al. (1993) sugeriram que as populações de D. noxia da França, África do Sul, México e EUA provavelmente têm a mesma origem, a Turquia. Shufram et al. (1997) não encontraram nenhuma diferença genética entre os 11 clones de $D$. noxia nos EUA submetidos a análise por RAPD-PCR, o que levou-os a sugerir que não há nenhum indicativo de alteração do status biotípico de $D$. noxia nos EUA.

Sunnucks et al. (1997) foram capazes de distinguir dois biótipos de Therioaphis trifolli (Monell) que se alimentam em alfafa e trevo na Austrália, utilizando além de variáveis como sobrevivência e reprodução em diferentes hospedeiros, morfologia, hidrocarbonetos presentes na cutícula, estudo dos cariótipos, o uso de RAPD-PCR e DNA mitocondrial (citocromo oxidase). T. trifolli que se alimenta de um determinado hospedeiro, alfafa ou trevo, apresenta pouca variação genética, e estes biótipos são geneticamente distintos.

Myzus persicae (Sulzer) e $M$. nicotianae Blackman não puderam ser separados com $100 \%$ de confiabilidade por RAPD-PCR em estudos realizados na Grécia. No entanto, a discriminação destas em relação a outras espécies de pulgões utilizados como grupos externos foi bastante satisfatória (Margaritopoulos et al., 1998). Estes estudos não revelaram importantes variações genéticas entre clones com diferentes origens, ciclo de vida ou planta hospedeira para o grupo $M$. persicae, sugerindo que as barreiras fisicas na Grécia podem não ter sido suficientes para promover o isolamento genético entre as populações (Margaritopoulos et al., 1998). Ao contrário, Black et al. (1992) trabalhando com outras espécies de pulgões encontraram variação genética entre biótipos, populações e indivíduos em uma mesma planta.

Black et al. (1992) identificaram diferenças entre e dentro de quatro espécies de pulgões, Schizaphis graminum (Rondani), D. noxia, Acyrthosiphon pisum (Harris) e Uroleucon ambrosiae (Thomas), mostrando diferenças genéticas entre biótipos destas espécies. Assim, RAPD-PCR poderia ser usado para rápida confirmação dos biótipos e para a procura de novos biótipos em nível de campo. A técnica de RAPD-PCR mostrouse extremamente útil para a rápida identificação de polimorfismo genético em afideos, o 
que provavelmente se deve ao fato desta técnica amplificar preferencialmente regiões altamente variáveis do genoma destes insetos (Black et al., 1992). Da mesma maneira, RAPD-PCR foi utilizada para estudo do grau de relação de diferentes grupos de afideos e separação de diferente taxa ou de espécies próximas, e até mesmo de clones, e mostrou-se como uma ferramenta muito útil para o estudo da estrutura populacional, diversidade genética entre e dentro de populações e migração em afideos (Cenis et al., 1993). A presença de parasitóides [Diaeretiella rapae (McIntosh) e Lysiphlebus testaceipes (Cresson)] em pulgões também puderam ser detectados através de RAPDPCR (Black et al., 1992).

Lin et al. (1999) estudaram através de RAPD-PCR populações naturais da cochonilha Daktulosphaira vitifolia (Fitch) coletadas em duas regiões distintas, uma no estado do Arizona onde avaliou-se três populações e outra em Nova York onde avaliouse seis populações. As populações de filoxera do Arizona se caracterizavam por serem geograficamente isoladas e pela ausência de migrantes alados. Estes dois fatores guiaram o grande grau de divergência genética observado entre as três populações e um baixo nível de variação dentro das populações, o que suporta a hipótese de que as barreiras geográficas têm restringido o fluxo gênico entre as populações. Em Nova York, as populações coletadas tinham relativa conexão pela distribuição de plantas hospedeiras e presença de migrantes alados com um alto grau de recombinação sexual, o que proporcionou em alguns casos maior similaridade entre indivíduos geograficamente mais distantes do que entre aqueles geograficamente mais próximos. No entanto, a magnitude do coeficiente de similaridade no Arizona foi similar ao de Nova York, sugerindo que a separação entre as duas regiões pode ter ocorrido em escala de tempo ecológica (décadas ou séculos). Os padrões RAPD-PCR foram completamente diferentes entre as duas regiões e o baixo coeficiente de similaridade $(0,62)$ entre as duas regiões, indicam que estas duas populações de filoxera são geneticamente distintas. Isto reflete a grande distância geográfica separando as populações, seleção hospedeira, e diferentes condições abióticas nas duas regiões (Lin et al., 1999).

$\mathrm{Na}$ Espanha, biótipos de Bemisia tabaci (Gennadius) puderam ser claramente distinguiveis por RAPD-PCR, mostrando a existência de dois diferentes tipos genéticos, 
biótipo A e B. Os dados de RAPD-PCR para todas as populações do biótipo B estudadas mostraram um alto grau de similaridade genética $(0,90)$, o que foi consistente com a hipótese de que o biótipo B de B. tabaci tem sido amplamente disseminado pelo mundo através de material de propagação contaminado (Guirao et al., 1997). Da mesma forma, estes dois biótipos puderam ser diferenciados na Colômbia através de RAPD-PCR, sendo este o primeiro registro do biótipo B de B. tabaci neste país (Quintero et al., 1998).

Marcadores moleculares do tipo RAPD-PCR foram utilizados para estudos genéticos de sete populações da mosca Cochliomyia hominivorax (Coquerel), seis do Brasil e uma da Argentina. Dos 209 locos gerados, 198 foram polimórficos, e estes foram submetidos a cinco metodologias de análise. Os índices de similaridade intrapopulacionais foram superiores a 0,7 e os interpopulacionais superiores a 0,5, indicando que as populações foram similares. $\mathrm{O}$ cálculo de heterozigosidade indicou que a diversidade genética nas populações é baixa e a análise de agrupamento não mostrou forte diferenciação entre as populações (Infante-Malachias et al., 1999). No entanto, o cálculo do $F_{(\mathrm{ST})}^{\prime}$ (Lynch \& Milligan, 1994) mostrou subdivisões genéticas nas populações $\left(F_{(\mathrm{ST})}^{\prime}=0,122\right)$ o que indica que $12 \%$ da variação genética nestas moscas é atribuída a moderada diferenciação entre as populações amostradas (Infante-Malachias et al., 1999). Ao contrário das populações da América do Norte, que são extremamente homogêneas, a variação encontrada entre as populações talvez se deva ao fato de que a América do Sul seja provavelmente o centro de origem desta mosca e conseqüentemente a variabilidade seja maior (Infante-Malachias et al., 1999).

A origem geográfica de três populações naturais da mosca-das-frutas Ceratitis capitata (Wiedemann) foi comparada a uma população de laboratório de origem conhecida através de RAPD-PCR, RFLP de mtDNA e isoenzimas. As duas primeiras técnicas proporcionaram o agrupamento da população de laboratório com uma das populações naturais cuja origem geográfica era a mesma, o que sugeriu que estas técnicas são mais confiáveis para a detecção da origem de populações dessa mosca. RAPD-PCR mostrou-se como uma técnica que permite fácil discriminação entre as populações, principalmente pela quantidade de marcadores obtidos (207) (Reyes \& 
Ochando, 1998). Haymer \& McInnis (1994) estudando populações de C. capitata observaram que populações de mesma origem geográfica (naturais e de laboratório) apresentavam o mesmo padrão RAPD-PCR, e também sugeriram a boa discriminação geográfica de populações por esta técnica. De acordo com Baruffi et al. (1995), para populações naturais de $C$. capitata de diversas partes do mundo, as técnicas de RAPDPCR e análise enzimática, forneceram resultados congruentes. No entanto, para análise de populações de laboratório, onde fatores interferem em fenômenos genéticos como a deriva, os resultados foram bastante diferentes entre estas duas técnicas. Estes autores observaram uma grande variabilidade genética para as populações de $C$. capitata através de RAPD-PCR, provavelmente causadas por deriva genética e seleção, no entanto um decréscimo desta variabilidade foi registrado na África Central em relação a regiões periféricas ao seu redor, o que reforçou a hipótese de que esta deve ser a população tropical ancestral.

Para a mosca-das-frutas Anastrepha suspensa (Loew) foi demonstrada a herdabilidade dos marcadores RAPD-PCR, que tem comportamento Mendeliano, e caso características comportamentais, como preferência hospedeira, estejam associadas a marcadores moleculares, a identificação de genes para determinado comportamento poderá ser possível. Assim, estes marcadores podem ser usados tanto para estudos de dinâmica populacional como para responder questões relacionadas com quarentena e raças geográficas (Schnell et al., 1996). Ainda em Diptera, visando a diferenciação entre espécies crípticas do gênero Drosophila Fallen do subgrupo pseudoobscura, Pascual \& Serra (1999) descreveram bandas RAPD-PCR espécie-específicas que puderam separar claramente D. pseudoobscura Frolowa, D. persimilis Dobzhansky \& Epling e D. miranda Dobzhansky.

Três ecotipos (univoltino, bivoltino e multivoltino) morfologicamente indiferenciáveis da mariposa Ostrinia nubilalis (Hübner), foram separados através de 21 bandas RAPD-PCR obtidas de 10 primers. Isto evidenciou uma possível variação genética entre estes ecotipos, e que esta técnica pode ser uma poderosa ferramenta para identificação de variação intraespecífica nesta mariposa, podendo ser usada até mesmo para se compreender se esta variação se deve a dispersão ou deriva genética (Pornkulwat 
et al., 1998). Xu et al. (1999) observaram extensa variabilidade genética entre e dentro de seis populações do gênero Ostrinia na China, no entanto, detectaram que uma população de $O$. furnacalis Guenée não mostrou significativa diferença genética das outras cinco populações de $O$. nubilalis. Isto pode ter ocorrido por uma falha na correta identificação taxonômica dos espécimes antes dos ensaios RAPD-PCR ou pelo fato de que um período relativamente curto tenha se passado desde o processo de especiação e nenhuma diferença genética entre as duas espécies tenha ocorrido.

Duas espécies simpátricas de mariposa, Choristoneura fumiferana (Clemens) e C. pinus Freeman, foram estudadas no Canadá com base em marcadores RAPD-PCR visando sua separação taxonômica. Foram utilizados espécimes de museu com idades variando entre 1 e 53 anos, e esta técnica permitiu a detecção de 9 bandas espécieespecífica para $C$. fumiferana e 8 para $C$. pinus. No entanto, alguns espécimes mostraram algumas bandas espécie-específica de ambas as espécies. Híbridos das duas espécies apresentariam todas as bandas das duas espécies, em função de um completo padrão aditivo, e isto não foi observado. Portanto, o que provavelmente ocorreu foi uma introgressão genética, ou seja, o cruzamento dos híbridos F1 com os parentais, o que levou alguns espécimes a exibirem mais bandas de uma espécie do que de outra. A ausência de barreiras reprodutivas espaciais, temporais, fisicas ou fisiológicas para estas duas espécies no Canadá foram requerimentos biológicos básicos para que a introgressão genética tenha ocorrido (DeVerno et al., 1998).

Schreiber et al. (1997) identificaram três marcadores RAPD-PCR específicos para discriminação de populações da mariposa Lymantria dispar L. da Ásia e da América do Norte, as quais foram introduzidas da Europa. Reineke \& Zebitz (1999) utilizaram estes marcadores (dentre outros) e também análise da região ITS-2, para verificação da possivel introdução ou migração de genótipos asiáticos para a Europa Central. Os resultados com as duas técnicas mostraram-se diferentes. A análise da região ITS-2 mostrou que esta migração ou introdução de $L$. dispar na Europa não ocorre, ao contrário do que revelou o RAPD-PCR, e isto pode estar em função, por exemplo, das diferentes regiões genômicas analisadas pelas duas técnicas. 
Para a borboleta Papilio machaon L., estudos com aloenzimas e RAPD-PCR revelaram um considerável fluxo gênico entre três populações deste lepidóptero em Broadland (Reino Unido). A análise de agrupamento, baseada em 109 locos gênicos RAPD-PCR encontrados, não permitiu a separação clara dos indivíduos dentro das populações as quais pertenciam. A hipótese de alto fluxo gênico como conseqüência de altas taxas de migração entre as populações foi suportada pelo baixo valor de distância genética e falta de correlação entre genética e distância geográfica encontrados (Hoole et al., 1999).

Vaughn \& Antolin (1998) demostraram através de RAPD-PCR que a vespa $D$. rapae mostra subdivisões genéticas em pequena escala espacial, ou seja, populações localizadas em áreas situadas a distâncias de $1 \mathrm{~km}$ ou menos são geneticamente distintas. Esta divergência foi mantida em avaliações no ano subseqüente, mostrando que cada uma destas populações estariam adaptadas a exploração de uma micro-condição ambiental e a migração entre locais poderia levá-las a perda desta adaptabilidade.

Segundo Landry et al. (1993) em Trichogramma spp. a técnica de RAPD-PCR poderia ser usada para rápida certificação e controle de qualidade destes insetos que são criados massalmente. Além de monitorar a deriva genética entre as populações e determinar o número mínimo de indivíduos para se começar uma criação massal, com um biótipo desejável, mantendo a integridade da criação por longo tempo.

Nos EUA, populações do himenóptero Cephus cinctus Norton de duas regiões, Montana e Dakota, foram avaliadas via RAPD-PCR para medida de variação genética dentro e entre as populações (Lou et al., 1998). Observou-se diferenças entre as populações e regiões e uma grande variação genética foi observada dentro das populações, sugerindo que isto aumentaria a chance de uma rápida adaptação às novas condições ambientais, o que seria particularmente importante para esta espécie que apresenta uma baixa longevidade e um limitado potencial de dispersão (Lou et al., 1998).

Visando diferenciar abelhas africanas e européias, Suazo et al. (1998) testaram 700 primers e obtiveram cinco deles capazes de detectar diferenças, embora nenhum deles tenha sido diagnóstico, ou seja, não estiveram presentes em todos os indivíduos da 
população testada. Esta pequena proporção de primers encontrados sugere que RAPDPCR não deve ser usado como um marcador genético diagnóstico em abelhas.

Aljanabi et al. (1998) observaram que a técnica de RAPD-PCR provê um eficiente método para diferenciação dos parasitóides Trissolcus teretis Johnson, $T$.urichi Crawford e T. basalis (Wollaston) encontrados em soja. Com relação ao parasitóide Telenomus podisi Asheamed a similaridade dentro da população avaliada foi superior 0,78 e o baixo polimorfismo genético observado sugere que as populações parecem ser muito homogêneas dentro de uma área de soja, podendo o RAPD-PCR ser usado para analisar populações geográficas e resolver eventuais questões taxonômicas a respeito da espécie (Aljanabi et al., 1998). Em Hymenoptera, RAPD-PCR também tem sido utilizado para construção de mapas genéticos, como para Trichogramma brassicae Bezdenko (Laurent et al., 1998) e para Apis mellifera L. (Hunt \& Page, 1995).

Silveira et al. (1998) estudaram populações do gafanhoto Schistocerca pallens (Thunberg) do Nordeste e do Brasil Central através de RAPD-PCR e encontraram uma alta variabilidade genética intrapopulacional, no entanto, a análise de agrupamento não permitiu uma distinta separação dos indivíduos destas regiões geográficas, também observaram baixo polimorfismo entre os isolados do fungo Metarhizium flavoviride Gams \& Rozspal utilizado no controle desta praga.

Estudos com RAPD-PCR e aloenzimas permitiram a separação de três espécies de besouros, Meligethes viridescens (Fabr.), M. czwalinai Reitter e uma nova espécie. A divergência genética obtida sugere um cenário evolutivo, através de isolamento geográfico, partindo de uma população polífaga ancestral, dando origem a duas linhagens com diferentes níveis de especialização da alimentação larval (Audisio et al., 2000).

RAPD-PCR tem se mostrado como uma das técnicas moleculares mais amplamente empregadas em Entomologia. Como uma importante ferramenta, tem ancorado diversas hipóteses e ajudado a elucidar inúmeras dúvidas nas mais variadas áreas. O sucesso desta técnica pode ser atribuído primariamente a rapidez para obtenção dos resultados e o baixo custo se comparado com outros métodos (Loxdale et al., 1996). 


\subsubsection{Preservação de DNA para análises genéticas}

Ácidos nucléicos, apesar de menos reativos quimicamente do que proteínas, são também vulneráveis a alterações oxidativas e hidrolíticas. Embora a taxa de reação seja relativamente lenta, alterações estruturais na molécula de DNA podem ocorrer extensivamente se este for estocado por longos períodos sob condições desfavoráveis (Dessauer et al., 1996). Segmentos de DNA altamente degradado tem sido isolado de amostras mumificadas, espécimes de museu, de amostras preservadas em álcool, tratadas com ácido picríco ou cloreto de mercúrio, fixados por longos períodos na ausência de tampão ou em excesso de formaldeído (Dessauer et al., 1996; Goelz et al., 1985). A quantidade de DNA extraído de espécimes mortos há muito tempo é da ordem de 5-20\% do que se pode extrair de espécimes frescos, sendo a maioria do DNA de fita simples e degradado em fragmentos de 200-300 pares de bases, embora alguns fragmentos com $>1 \mathrm{~Kb}$ de tamanho podem estar presentes (Houde \& Braun, 1988). Algumas das técnicas moleculares baseadas na PCR podem fazer uso de amostras de DNA com algum grau de degradação (Reiss et al., 1995), no entanto, técnicas como RAPD-PCR requerem um DNA íntegro, apesar de alguns autores terem relatado sucesso no uso desta técnica com espécimes de museu (DeVerno et al., 1998; Reineke \& Zebitz, 1999).

Devido a muitos obstáculos que freqüentemente limitam a possibilidade de se utilizar espécimes frescos em análises genéticas, e já que a extração do DNA e subseqüente amplificação via PCR podem ser drasticamente alterada pelo método utilizado para matar e preservar os espécimes em estudo (Austin \& Dillon, 1997), a importância de métodos adequados para a preservação de amostras tem aumentando muito (Dessauer et al., 1996; Post et al., 1993). No entanto, poucos estudos têm sido realizados visando a utilização de DNA extraído de insetos mantidos em algum método de preservação (Austin \& Dillon, 1997; Dillon et al., 1996; Logan, 1999; Post et al., 1993; Reiss et al., 1995). Em alguns outros organismos, como vertebrados, estes estudos também têm sido realizados (Bramwell \& Burns, 1988; Goelz et al., 1985; Oakenfull, 
1994; Smith et al., 1987), porém, os resultados nem sempre são aplicáveis a insetos (Logan, 1999; Post et al., 1993).

Post et al. (1993) estudaram alguns métodos de preservação para o díptero Simulium damnosum Theobald. Os melhores métodos foram nitrogênio líquido, etanol absoluto a $4^{\circ} \mathrm{C}$ e amostras dessecadas em sílica gel. Resultados semelhantes foram obtidos por Dillon et al. (1996) com as espécies de Hymenoptera, Venturia canescens (Gravenhorst) e Leptomastix dactylopii Howard. Outros métodos como formol salino (10\%) e espécimes de museu não forneceram quantidades de DNA detectáveis e o DNA de espécimes em solução de Carnoy (etanol: ácido acético - 3:1), metanol ou propanol mostrou-se muito degradado (Post et al., 1993).

No besouro Amara glacialis (Manner-heim), a estocagem dos espécimes a $-80^{\circ} \mathrm{C}$ foi a mais satisfatória, bons resultados também foram conseguidos em tampão de extração. Em etanol a temperatura ambiente, o DNA foi preservado por aproximadamente 73 dias, no entanto, em etil acetato e solução de Carnoy o mesmo não se preservou (Reiss et al., 1995).

Para duas espécies de Odonota, Enallagma civile (Hagen) e Hetaerina americana (F.), os espécimes receberam uma injeção de acetona no tórax e foram mantidos neste fixador por 24 horas antes de serem secos ao ar (Logan, 1999). Este método permitiu a preservação do DNA, não se observando efeitos da acetona ou tempo de preservação, na extração, amplificação e seqüenciamento posteriores (Logan, 1999). Alguns métodos químicos de secagem também foram utilizados com sucesso para $V$. canescens e L. dactylopii (Austin \& Dillon, 1997).

As alterações estruturais nos ácidos nucléicos podem ser prevenidas mantendo-se o DNA, ou as amostras do qual o mesmo será extraído, em baixas temperaturas e na ausência de oxigênio. A desidratação, altas concentrações de sais e EDTA para inibir as nucleases são fatores adicionais que estabilizam o DNA (Dessauer et al., 1996) e também a manutenção de um pH entre 8,0 e 9,0 para se evitar o pH ótimo para enzimas degradativas como as lipolíticas e lipoxigenases ( $\mathrm{pH}$ entre 5,0 e 6,0) e DNAses nucleares (pH em torno de 7,0) (Ferreira \& Grattapaglia, 1996). 


\section{MIGRAÇÃO COMO UMA ESTRATÉGIA DE SOBREVIVÊNCIA DE Dalbulus maidis (DeLONG \& WOLCOTT) (HEMIPTERA: CICADELLIDAE) DURANTE A ENTRESSAFRA DO MILHO NO BRASIL CENTRAL}

RESUMO - A cigarrinha-do-milho, Dalbulus maidis, é uma das principais pragas do milho (Zea mays L.) na América Latina por transmitir três patógenos associados ao enfezamento do milho: Spiroplasma kunkelii Withcomb et al., o fitoplasma do milho ("maize bushy stunt phytoplasma" - MBSP) e o vírus da risca ("maize rayado fino vírus" - MRFV). Por ser o milho o único hospedeiro conhecido de D. maidis no Brasil, esta cigarrinha parece ter duas alternativas para sua sobrevivência na entressafra da cultura, migração e/ou dormência em restos culturais ou áreas adjacentes. Para investigar estas possibilidades, populações de $D$. maidis foram monitoradas quinzenalmente através de cartões adesivos amarelos dupla face $(7 \times 12 \mathrm{~cm})$ por períodos que variaram de 15 a 29 meses, no município de Anastácio/MS. Esta região é caracterizada por áreas extensas de pastagens e por apresentar pequenas áreas de plantio de milho com um longo período de entressafra (6-7 meses). $\mathrm{O}$ monitoramento foi realizado em cinco áreas representando duas situações distintas: a) áreas (I e II) onde o milho era plantado anualmente a partir de outubro; e b) áreas (III, IV, Va e Vb) de pastagem, onde o milho não era plantado há pelo menos 5 anos. Simultaneamente, realizou-se um monitoramento também em Piracicaba/SP, em uma área onde o milho é plantado continuamente por todo ano (área VI). Em cada uma das áreas, foram colocados 16 a 18 cartões dentro da área onde o milho foi plantado (inclusive nas áreas de pastagem), em três alturas $(0,5,1,5$ e $2,5 \mathrm{~m})$, além de 4 outros cartões $(0,5$ e $1,5 \mathrm{~m})$ posicionados em 
vegetação arbórea adjacente ao plantio do milho (áreas I, II e Va) e 8 placas de metal amarelas adesivas $(30 \times 30 \mathrm{~cm}$ ) em alturas de 7, 13 e $16 \mathrm{~m}$ (área VI). Espécimes de $D$. maidis foram coletados em plantios de milho em todas as áreas estudadas, mas não na vegetação adjacente aos plantios (coletas com cartões, com rede de varredura ou succionador motorizado); espécimes também foram capturados nas alturas de 7, 13 e 16 $\mathrm{m}$, em Piracicaba/SP. Picos populacionais simultâneos foram observados no período de julho a outubro em todas as áreas de Anastácio/MS, quando não havia milho no campo; estes picos foram maiores nas áreas onde o solo encontrava-se exposto pela aração e/ou gradagem. Verificou-se inversão da razão sexual em favor das fềmeas no início e final da safra do milho, e em coletas de entressafra nas áreas de Anastácio/MS, mas não em Piracicaba/SP. A não captura de D. maidis na vegetação adjacente aos campos de milho e sua coleta em todos os plantios de Anastácio/MS, inclusive nas áreas de pastagem (III, $\mathrm{IV}$, Va e $\mathrm{Vb}$ ) onde o milho não era cultivado há vários anos, e também em alturas superiores a $7 \mathrm{~m}$, reforçam a hipótese de que adultos de $D$. maidis podem migrar longas distâncias, possivelmente através de correntes de vento, para localização de novos plantios e sobrevivência na entressafra do milho. $\mathrm{O}$ grande número de espécimes coletados em áreas onde o solo estava arado sugere que este pode ser um estímulo importante na escolha da área para o pouso por adultos migrantes de D. maidis.

PALAVRAS-CHAVE: cigarrinha-do-milho, vetor, Zea mays, ecologia.

\section{MIGRATION AS A STRATEGY FOR SURVIVAL OF Dalbulus maidis (DeLONG \& WOLCOTT) (HEMIPTERA: CICADELLIDAE) DURING CORN OVERSEASON IN CENTRAL BRAZIL}

SUMMARY - The corn leafhopper, Dalbulus maidis, is one of the main pests of maize (Zea mays L.) in Latin America, because it is the vector of three pathogens associated with the corn stunt disease: Spiroplasma kunkelii Withcomb et al. (corn stunt spiroplasma - CSS), maize bushy stunt phytoplasma (MBSP) and the maize rayado fno 
virus (MRFV). Because maize is the only known host of D. maidis in Brazil, this leafhopper might use two possible strategies for survival during crop overseason: migration or dormancy in cultural remains or adjacent areas. To investigate these possibilities, populations of $D$. maidis were monitored biweekly through two-sided yellow sticky card traps $(7 \times 12 \mathrm{~cm})$ for periods that varied from 15 to 29 months, in the region of Anastácio, State of Mato Grosso do Sul (MS). This region is characterized by extensive areas of pastures and small areas of maize plantings with a long overseason period (6-7 months). The survey was accomplished in five areas representing two different situations: a) areas (I and II) where a single maize crop is planted annually in the spring; and b) areas (III, IV, Va and Vb) of perennial pastures, where maize had not been planted in the previous 5 years. A similar and simultaneous survey was carried out in Piracicaba/SP, in one area where maize is grown year round (area VI). In each one of the areas, 16 to 18 yellow card traps were placed within the plot where maize was planted (including in the pasture areas), at three different heights $(0,5,1,5$ and 2,5 m). In addition, 4 other cards (at 0,5 and 1,5 m) were placed in arboreal vegetation adjacent to the maize plantings in Anastácio (areas I, II and Va) and 8 yellow sticky plates (30x30 $\mathrm{cm}$ ) were distributed at the heights of 7,13 and $16 \mathrm{~m}$ in Piracicaba (area VI). Specimens of $D$. maidis were collected in maize plantings in all areas studied, but not in the vegetation adjacent to the plantings (sampling with yellow sticky cards, sweeping net or portable suction trap); specimens were also captured at the heights of 7, 13 and $16 \mathrm{~m}$ in Piracicaba/SP. Simultaneous population peaks were observed in the period of July to October in all of the areas of Anastácio/MS, when there was no maize in the field; these peaks were higher in the areas where the soil had been plowed recently. Sexual ratio was inverted in favor of females both at the onset and at the end of the crop season, as well as during maize overseason in the areas of Anastácio/MS, but not in Piracicaba/SP. Some facts such as the absence of $D$. maidis in the vegetation adjacent to the maize fields and its capture in all of the plantings of Anastácio/MS, including in the pasture areas (III, IV, Va and Vb) where the maize had not been cultivated for several years, as well as trapping of flying adults at $16 \mathrm{~m}$, reinforce the hypothesis that adults of $D$. maidis migrate long distances, possibly through wind currents, for location of new 
plantings and survival in the corn overseason. The great number of specimens collected in areas where the soil had been plowed suggests that plowing can be an important cue in the choice of the area for landing by migratory adults of $D$. maidis.

KEY WORDS: corn leafhopper, vector, Zea mays, ecology

\subsection{INTRODUÇÃO}

A cigarrinha-do-milho, Dalbulus maidis (DeLong \& Wolcott), que tem como centro de origem o México (Nault \& DeLong, 1980), encontra-se amplamente distribuída desde o sul dos EUA até a Argentina (Nault, 1990; Oman, 1948), provavelmente em função de sua grande mobilidade (Gámez, 1983) e associação com o milho cultivado cuja distribuição pelas Américas foi guiada pelo homem (Triplehorn \& Nault, 1985). D. maidis tem sido relatada como a única espécie do gênero Dalbulus DeLong no Brasil (Oliveira, 1996) e como a espécie de cigarrinha mais abundante em milho (Oliveira, 1996; Waquil, 1997). A despeito de seus danos diretos pela suç̧ão de seiva (Bushing \& Burton, 1974; Waquil, 1997), sua grande importância está na capacidade de transmitir de forma persistente e propagativa três patógenos do milho, Spiroplasma kunkelii Whitcomb et al. ("corn stunt spiroplasma"- CSS) agente causal do enfezamento pálido, o fitoplasma do milho ("maize bushy stunt phytoplasma"- MBSP) agente causal do enfezamento vermelho e o vírus da risca ("maize rayado fino virus"MRFV), o que levou esta cigarrinha a ser considerada como a mais séria praga do milho na América Latina (Nault, 1980; 1990).

No Brasil, estudos com este vetor e patógenos associados são incipientes. Por outro lado, no México e América Central vários estudos têm sido realizados com $D$. maidis no que diz respeito à biologia, relações filogenéticas, comportamento, morfologia e transmissão de fitopatógenos. Especula-se que esta cigarrinha seja o único hospedeiro de entressafra para os patógenos por ela carregados (Ebbert \& Nault, 1994), porém 
curiosamente pouco se sabe a respeito de como D. maidis sobrevive na entressafra do milho (Larsen et al., 1992).

Mecanismos de sobrevivência de D. maidis a condições desfavoráveis, como o período de entressafra do milho, podem envolver três estratégias: hospedeiros altemativos, dormência e/ou migração. No inverno seco do México Central, D. elimatus (Ball) que também se alimenta de milho, estabelece populações em plantações de trigo irrigadas ou em algumas plantas daninhas como Bromus laciniatus Beal e B. inermis Leyss (Barnes, 1954). Em outras regiões do México, D. maidis pode ser encontrada em pequenas populações em teosintos (Zea spp.) perenes (Triplehorn \& Nault, 1985). Entretanto, esta não parece ser a estratégia adotada por D. maidis para sobrevivência na entressafra na maior parte da América Latina, uma vez que os teosintos são plantas restritas ao sul de Jalisco (México) e a cigarrinha-do-milho tem ampla distribuição pelas Américas. Além disso, a gama de plantas hospedeiras de reprodução e desenvolvimento relatada para $D$. maidis é restrita ao milho, teosintos e Tripsacum dactyloides (L.) (Barnes, 1954; Larsen et al., 1992; Nault, 1980; Pitre et al., 1966). A permanência em restos culturais do milho também é refutada (Larsen et al., 1992). A dormência, embora muitos a julguem como uma estratégia única de insetos de zona temperada, é também comum em insetos de regiões tropicais (Denlinger, 1986; Masaki, 1980); por exemplo, alterações qualitativas em plantas de milho podem induzir diapausa em Busseola fusca (Fuller) (Usua, 1973) e Chilo spp. (Scheltes, 1978). Para D. maidis e suas congêneres no México, no entanto, este fenômeno não ocorre (Larsen et al., 1992).

Algumas evidências apontam uma possível estratégia migratória para $D$. maidis. A migração e dispersão parecem ser mecanismos relevantes para espécies que, como D. maidis, exploram um hábitat não permanente como o milho (Nault, 1990). Estudos do comportamento de fuga têm demonstrado que D. maidis e D. elimatus, especialistas em milho, são mais sensíveis a distúrbios, estando mais propensas ao vôo do que outras espécies de Dalbulus, que utilizam gramíneas perenes, talvez em função de que as primeiras necessitem buscar hábitat alternativo na entressafra do milho (Heady \& Nault, 1985). Larsen et al. (1992) utilizaram cartões adesivos amarelos para o monitoramento de populações da cigarrinha-do-milho e capturaram altas populações de 
D. maidis no final da safra do milho, quando este já estava seco. Observaram também que a segunda geração de fềmeas, criadas em condições que simulavam o outono, poderiam sobreviver até dois meses sem alimento e tão somente com suprimentos de água, donde concluíram que esta espécie é uma migrante local, passando do milho para outro hábitat próximo, na entressafra, e retomando ao campo de milho no ano seguinte. Por outro lado, a migração a longas distâncias também parece ser possível. Esta hipótese é sustentada por episódios como a epidemia de CSS no sul da Flórida em 1979, supostamente ocasionada por cigarrinhas que teriam migrado das Ihas do Caribe (Bradfute et al, 1981). Taylor et al. (1993) estudaram a atividade de vôo da cigarinhado-milho e mais duas espécies do gênero Dalbulus, em condições de laboratório que simulavam diferentes fotoperíodos, condições de planta hospedeira e diferentes estações do ano no México Central. Observaram que $D$. maidis possui um comportamento de vôo consistente com vôos migratórios de inverno, o que coincidiria com correntes de vento ("El Norte") que levariam estas cigarrinhas das regiões altas do México Central, onde o inverno é frio e seco, para regiões de baixa altitude próximas ao Golfo, onde chuvas de inverno e primavera são comuns e onde o milho é plantado extensivamente. $\mathrm{O}$ aparecimento súbito de D. maidis no início da estação chuvosa, logo após o plantio do milho no México Central, por sua vez, coincidiria com a chegada da corrente de vento denominada Zona de Convergência Inter-Tropical, que traz as chuvas do golfo do México para as regiões centrais.

Se D. maidis possui hábito migratório, e se este é apenas local ou a longas distâncias, é algo que tem sido especulado e para o qual existem algumas evidências. Porém, evidências mais contundentes poderiam ser obtidas se algumas das seguintes perguntas pudessem ser respondidas:

- Considerando-se a hipótese de que as populações de D. maidis são todas locais (Larsen et al., 1992), seria esperada a ocorrência desse inseto logo após o plantio do milho em região isolada de grandes cultivos, em área onde esse cereal não era cultivado?

- Nesta mesma região, em áreas onde o milho é cultivado em pequenas lavouras, uma única vez por ano e onde a entressafra se extende por 6-7 meses, seria esperada a 
observação da cigarrinha-do-milho na entressafra, em vegetação adjacente ou hábitats próximos?

- Qual é a época exata em que D. maidis chega na cultura do milho, antes, durante ou após a germinação das plantas?

- D. maidis pode ser coletada em alturas maiores do que aquelas que as cigarrinhas geralmente utilizam para vôos triviais em busca de alimento e de um parceiro para cópula?

Buscando responder a essas perguntas, realizou-se um monitoramento extensivo da ocorrência e atividade de $D$. maidis na região de Anastácio/MS, onde predominam pastagens perenes e o milho é plantado em pequena escala, havendo uma entressafra prolongada, e também em Piracicaba/SP, em área onde o milho é cultivado o ano inteiro.

\subsection{MATERIAL E MÉTODOS}

O experimento teve duração de 29 meses, e foi instalado no município de Anastácio/MS (20⒉ $29^{\prime} 01^{\prime \prime} \mathrm{S} ; 55^{\circ} 48^{\prime} 25^{\prime \prime} \mathrm{W}$ e $160 \mathrm{~m}$ de altitude), com cinco áreas experimentais, sendo que duas das quais foram avaliadas por apenas 28 e 15 meses. Outro município envolvido neste estudo foi Piracicaba/SP (22 $43^{\prime} 31^{\prime \prime}$ S; $47^{\circ} 38^{\prime} 57^{\prime \prime}$ W e $547 \mathrm{~m}$ de altitude), contando com uma área experimental que foi avaliada por 28 meses.

\subsubsection{Características das áreas experimentais}

Em Anastácio/MS, foram escolhidas duas áreas (I e II) onde se fazia um único plantio anual de milho, e três áreas de pastagens perenes (III, IV e V) onde o milho não 
era cultivado há mais de 5 anos (Figuras 1 e 2; Apêndice 1). As áreas III, IV e V eram distantes pelo menos $20 \mathrm{~km}$ das áreas I e II (Figura 2).

a) área I: propriedade rural localizada $\mathrm{a} \approx 30 \mathrm{~km}$ do centro urbano, com área de $\approx 20$ ha. Aproximadamente 3-4 ha eram dedicados ao plantio anual do milho há pelo menos 5 anos. Vegetação nativa (principalmente gramíneas) com árvores de pequeno porte próximo à área do experimento, além de outras culturas como banana e capim elefante, e algumas áreas de pastagem. Após as duas safras do milho do experimento plantou-se o feijão;

b) área II: propriedade rural localizada $\mathrm{a} \approx 30 \mathrm{~km}$ do centro urbano, com área de $\approx 20$ ha, onde aproximadamente 3-4 ha eram dedicados ao plantio do milho em única safra anual, há pelo menos 5 anos. Presença de mata, com árvores de grande porte, próxima a área do experimento, além de pastagem. No primeiro ano do experimento plantou-se feijão após o milho e no segundo, melancia;

c) área III: propriedade rural $\mathrm{a} \approx 8 \mathrm{~km}$ do centro urbano, com área de $\approx 70$ ha utilizados para pastagem (braquiária). Plantio de milho mais próximo em um raio superior a $20 \mathrm{~km}$. Nesta área o milho foi plantado apenas no primeiro ano do experimento; a partir do segundo ano a área foi utilizada para pastagem (braquiária). Mata de médio porte próxima a área do experimento, com presença de algumas árvores $\mathrm{e}$ arbustos dentro da área experimental;

d) área IV: propriedade rural $\mathrm{a} \approx 10 \mathrm{~km}$ do centro urbano, com área de $\approx 70$ ha utilizados para pastagem (braquiária). Plantio de milho mais próximo em um raio superior a $20 \mathrm{~km}$. Nesta área o milho foi plantado nos dois anos do experimento; na entressafra a área permaneceu coberta por vegetação nativa (principalmente gramíneas). Plantios de melancia, tomate, beringela, pimentão, dentre outros, próximos à área do experimento;

e) área $\mathrm{V}$ : propriedade rural $\mathrm{a} \approx 5 \mathrm{~km}$ do centro urbano, com área de $\approx 70$ ha utilizados para pastagem (braquiária). Plantio de milho mais próximo em um raio superior a $20 \mathrm{~km}$. Esta área foi avaliada por 15 meses, sendo subdividida em duas áreas, $\mathrm{Va}$ e $\mathrm{Vb}$, distanciadas de $\approx 500 \mathrm{~m}$. Na área $\mathrm{Va}$, após o plantio do milho cultivou-se feijão 
de porco; a área $\mathrm{Vb}$ permaneceu coberta por pastagem (braquiária) durante todo $\mathrm{o}$ experimento. Plantio de banana e mandioca, além de uma área de mata de médio porte próximos à área $\mathrm{Vb}$; área $\mathrm{Va}$ era cercada por pastagem (braquiária).

Em Piracicaba/SP foi estabelecida a área VI no campo experimental do Departamento de Genética da ESALQ/USP, onde o milho é plantado de forma escalonada durante todo o ano, em áreas contíguas ao talhão experimental (Figura 2). No primeiro ano do experimento, após o plantio do milho, o solo permaneceu coberto por plantas daninhas; no segundo ano cultivou-se o feijão e milho em consórcio.

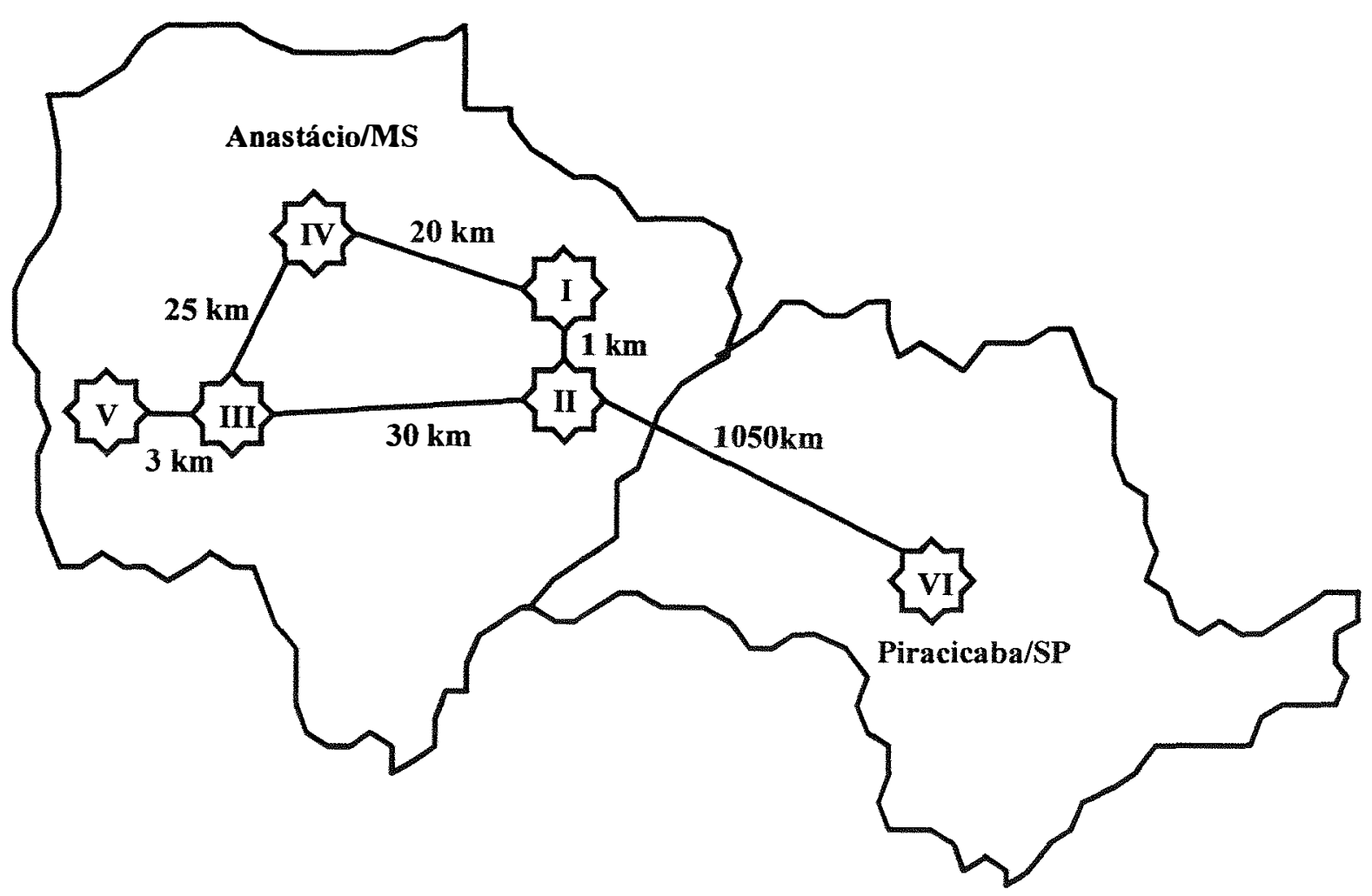

Figura 1. Localização das áreas experimentais em Anastácio/MS, e Piracicaba/SP, com a distância aproximada entre os municípios e entre as áreas. 


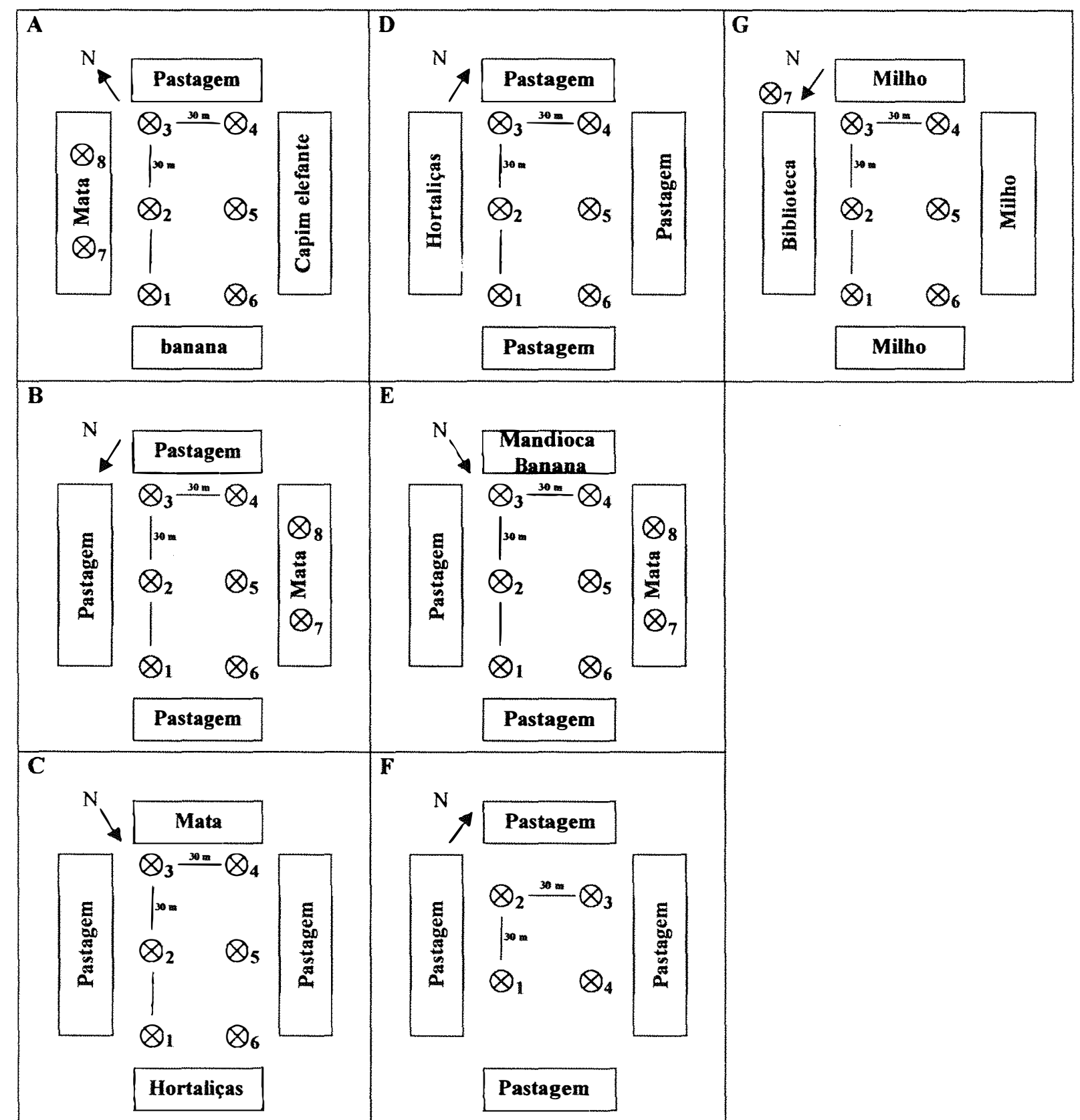

Figura 2. Croquis das áreas experimentais. A) área I, B) área II, C) área III, D) área IV, E) área $\mathrm{Va}, \mathrm{F}$ ) área $\mathrm{Vb}$, todas localizadas no município de Anastácio/MS e G) área VI, no município de Piracicaba/SP. Os números de 1-8 indicam a posição dos vergalhões onde foram colocados os cartões adesivos amarelos $(7 \times 12 \mathrm{~cm})$ e as placas de metal amarelas $(30 \times 30 \mathrm{~cm})$ com cola "sticky". Os cartões adesivos foram posicionados nas alturas de $0,5,1,5$ e 2,5 m nos vergalhões 1 , 3, 4, e 6 de A-E, 1 e 3 em F e 1-6 em G, e nas alturas de 0,5 e 1,5 m nos vergalhões $2,5,7$ e 8 de A-E e 2 e 4 em F. Em G, o número 7 indica a posição das placas de metal amarelas colocadas nas alturas de 7, 13 (2 placas) e $16 \mathrm{~m}$ (4 placas). $\mathrm{N}$ indica o Norte magnético. 


\subsubsection{Coletas com cartões adesivos}

Em cada uma das áreas experimentais foram colocados 16 cartões adesivos amarelos dupla face $(7 \times 12 \mathrm{~cm})$ (Olson Products, Medina, Ohio, EUA), uma vez que o amarelo é a cor mais atrativa para $D$ maidis (Todd et al., 1990a,b). Os cartões foram amarrados a hastes de metal $(20 \mathrm{~cm})$ soldadas a vergalhões de ferro $(1,2 \mathrm{~cm}$ de diâmetro), em alturas de 0,5, 1,5 e 2,5 m do nível do solo (Apêndice 1). As faces dos cartões foram posicionadas com orientação Norte-Sul, por ser essa a direção predominante dos ventos na região. Os vergalhões foram dispostos em duas linhas paralelas de 3 , distanciadas de $30 \mathrm{~m}$, sendo esta mesma distância respeitada entre os vergalhões na linha, formando um retângulo de $1800 \mathrm{~m}^{2}$, dentro das áreas destinadas ao plantio do milho (Figura 2). Nos vergalhões intermediários de cada uma das 2 linhas, foram colocados cartões adesivos apenas nas alturas de 0,5 e 1,5 m. Uma exceção foi a área $\mathrm{Vb}$ que conteve apenas 10 cartões dispostos em 4 vergalhões: dois com as alturas de 0,5, 1,5 e 2,5 $\mathrm{m}$ e dois com as alturas de 0,5 e 1,5 m. Nas áreas I, II e Va também foram colocados 4 cartões adesivos no interior das matas adjacentes, dispostos em dois vergalhões nas alturas de 0,5 e 1,5 m (Figura 2).

$\mathrm{Na}$ área VI (Piracicaba/SP), foram também colocadas 2-4 placas de metal amarelas (30x $30 \mathrm{~cm})$ com cola "sticky" nas duas faces, em alturas de 7, 13 e $16 \mathrm{~m} \mathrm{em}$ uma caixa d'água localizada próxima à área experimental.

Os cartões adesivos e as placas foram trocados a cada 15 dias durante todos os meses do experimento, inclusive na entressafra, sendo levados ao laboratório para triagem e contagem do número de espécimes de $D$. maidis coletados e determinação da razão sexual. 


\subsubsection{Plantio do milho}

A partir de outubro de cada ano, foi realizado o preparo convencional do solo, adubação (NPK 4:14:8) e plantio do milho (variedade BR-106) em todas as áreas, com exceção da área $\mathrm{Vb}$, nos locais onde estavam locadas as armadilhas adesivas, em área mínima de $2000 \mathrm{~m}^{2}$.

\subsubsection{Procedimentos de entressafra}

Após a safra do milho nas áreas $\mathrm{I}-\mathrm{V}$, foram efetuadas numerosas amostragens de cigarrinhas através de rede entomológica e succionador motorizado na vegetação (principalmente gramíneas) próxima às áreas experimentais, além de inspeção visual nos restos culturais, visando à detecção de possíveis hábitats ou hospedeiros alternativos de D. maidis. Todas as coletas com cartões adesivos foram mantidas na entressafra.

\subsection{RESULTADOS}

Um total de 21.709 espécimes de $D$. maidis (Apêndice 2) foram coletados em 6.034 cartões adesivos amarelos avaliados nas seis áreas experimentais no decorrer de todo o período de avaliação. Nas placas de metal amarelas com cola "sticky", colocadas em Piracicaba/SP, foram coletados 125 espécimes em um total de 392 placas avaliadas (Tabela 1). D. maidis foi coletada em todas as áreas experimentais (Figuras 3-6), inclusive nas áreas de pastagem (III, IV e V) onde o milho não havia sido cultivado por no mínimo 5 anos. Nas áreas I, II e VI a cigarrinha-do-milho foi coletada quase que 
Tabela 1. Número total e média de adultos de Dalbulus maidis coletados por cartão adesivo amarelo $(7 \times 12 \mathrm{~cm})$ e placa de metal amarela nas seis áreas experimentais, durante todo o estudo.

\begin{tabular}{ccccc}
\hline \hline Município & Armadilha & Area & $\begin{array}{c}\text { Total de } \\
\text { cigarrinhas }\end{array}$ & $\begin{array}{c}\text { Média por } \\
\text { cartão/placa }\end{array}$ \\
\hline Anastácio/MS & Cartão adesivo $(7 \times 12 \mathrm{~cm})$ & I & 5.184 & 4,5 \\
& & II & 5.725 & 4,96 \\
& & III & 578 & 0,63 \\
& & IV & 2.672 & 3,00 \\
& & Va & 1.096 & 1,79 \\
& & Vb & 55 & 0,18 \\
\hline Piracicaba/SP & Cartão adesivo $(7 \times 12 \mathrm{~cm})$ & VI & 6.399 & 6,39 \\
& Placas de metal $(30 \times 30 \mathrm{~cm})$ & VI & 125 & 0,32 \\
\hline
\end{tabular}

ininterruptamente durante todo o período do estudo (Figuras 3 e 6). Nas áreas III, IV e Va a coleta de $D$. maidis se concentrou durante o período em que o milho foi cultivado, havendo períodos de menor coleta quando não havia milho no campo, intercalado por períodos onde não se observou a presença desta cigarrinha (Figuras 4 e $5 \mathrm{~A}$ ). $\mathrm{Na}$ área $\mathrm{Vb}$ detectou-se apenas um pico de coleta (Figura 5B). Observou-se a coleta de D. maidis em alturas de 7,13 e $16 \mathrm{~m}$ através das placas de metal amarelas (Figura 7). 0 total de cigarrinhas coletadas foi maior nas áreas I, II e VI do que nas demais áreas, o que pode ser comprovado pela média de cigarrinhas coletadas por cartão adesivo (Tabela 1).

Em Anastácio/MS, simultaneamente em todas as áreas avaliadas, observou-se um aumento no número de cigarrinhas coletadas nos meses de julho e agosto de $1998 \mathrm{e}$ 1999. Em nenhuma das áreas havia milho plantado neste período, e estes picos de coleta foram extremamente altos na área II onde o solo, nos dois anos, se encontrava completamente preparado (arado e gradeado), sem nenhum tipo de cobertura vegetal (Figura 3B). Picos de coleta de D. maidis foram observados em praticamente todas as áreas todas as vezes que o solo foi preparado seja para o plantio do milho, de outra cultura como o feijão ou para a reforma de pastagem (Figuras 3-6), porém a quantidade de cigarrinhas foi variável dependendo da época do ano em que este preparo do solo foi feito. Em outubro de 1998, picos populacionais simultâneos da cigarninha-do-milho 
também foram observados em todas as áreas (com exceção da $\mathrm{Vb}$ ), quando também não havia milho no campo (com exceção da área $\mathrm{Va}$ ), e mais uma vez este pico foi maior nas áreas onde o solo se encontrava preparado (Figuras 3-6). $\mathrm{Na}$ área situada em Piracicaba/SP (área VI), onde o milho é plantado praticamente o ano todo, uma maior quantidade de cigarrinhas foi coletada em relação às demais áreas avaliadas; nesta área o preparo do solo também parece ter certa influência sobre o montante de espécimes coletados.

Diferenças nas coletas de machos e fềmeas da cigarrinha-do-milho foram observadas em todas as áreas. Nas áreas de I a V em Anastácio/MS, a quantidade de machos coletados foi superior a de fềmeas durante a safra do milho (Figuras 8-10). Entretanto, nos períodos que antecederam o plantio, no final da safra e durante os picos de coleta fora da safra do milho a quantidade de fềmeas coletadas foi maior ou muito próxima a de machos, com raras exceções (Figuras 8-10). Em Piracicaba/SP, no entanto, a quantidade de machos coletados foi sempre superior a de fềmeas, havendo algumas poucas datas de coleta em que estas capturas se igualassem (Figura 11). Nas placas de metal amarelas, o total de fềmeas coletadas foi maior que o de machos, e estas representaram $69 \%$ do total coletado, sendo que a maioria (75\%) dos espécimes foi capturada a $16 \mathrm{~m}$ de altura.

Com relação à altura de captura com cartões adesivos, a maioria dos espécimes de D. maidis foram coletados a $0,5 \mathrm{~m}$ do nível do solo (Figuras 12-15). Este padrão se manteve em todas as áreas e épocas do ano, exceto durante o cultivo do milho, onde a partir do meio da safra a captura a 1,5 m começou a aumentar e via de regra superou a captura a $0,5 \mathrm{~m}$, possivelmente devido ao crescimento das plantas de milho. A captura a 2,5 m manteve-se em níveis muito baixos durante todas as épocas avaliadas e em todas as áreas, nunca chegando a ser a altura de captura predominante. Os níveis de captura a 2,5 m só apresentaram algum aumento durante picos populacionais muito altos ou em algumas áreas no final da safra do milho (Figura 12). Em todos os picos populacionais fora da safra do milho, principalmente nos picos ocorridos nas datas em que o solo estava preparado, a captura a $0,5 \mathrm{~m}$ foi muito maior que nas outras alturas, em todas as áreas avaliadas (Figuras 12-15). 

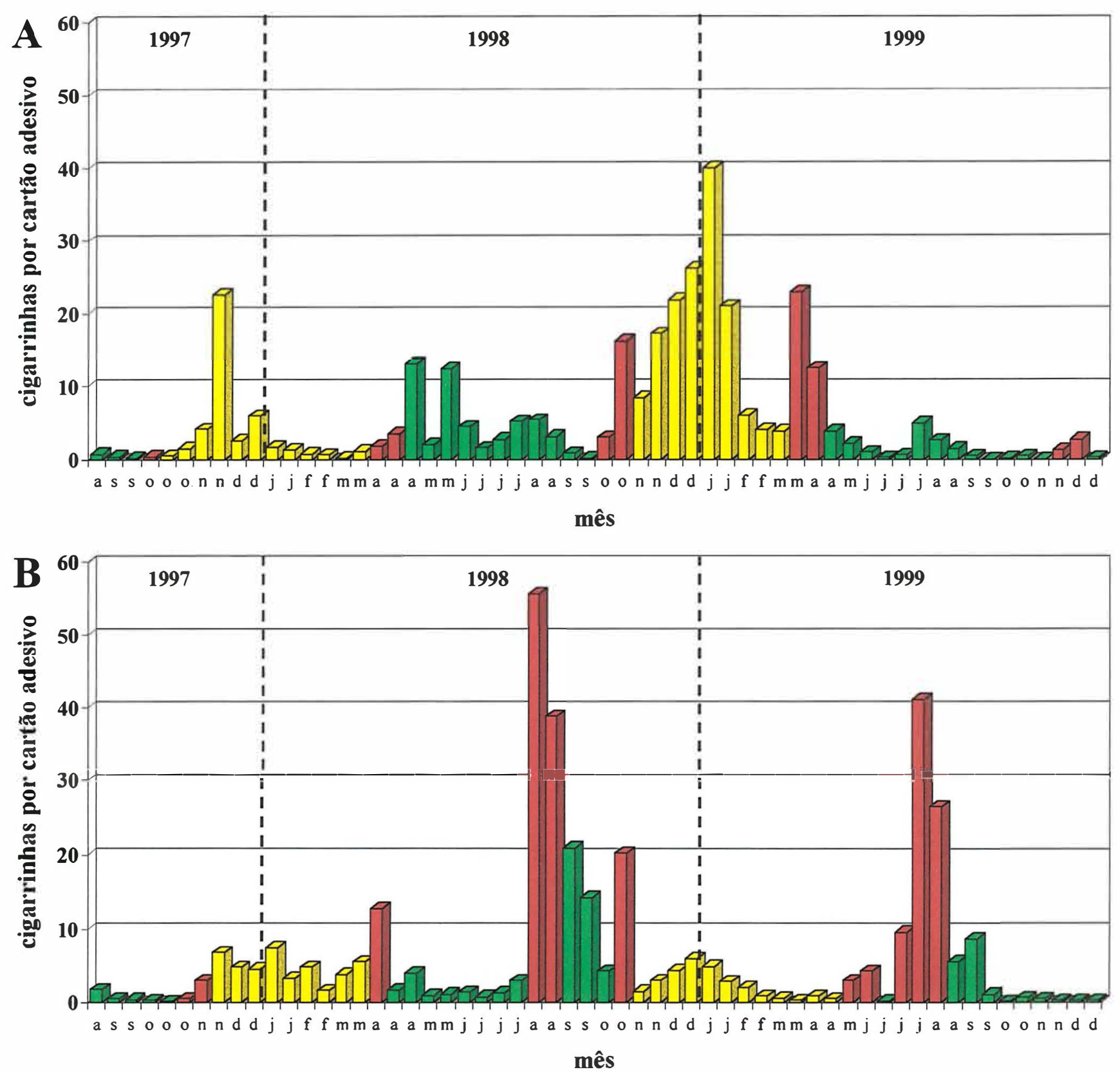

Figura 3. Número médio de adultos de Dalbulus maidis coletados por cartão adesivo amarelo no município de Anastácio/MS, em áreas onde o milho era plantado uma vez por ano: A) área I e B) área II (período de agosto/97 a dezembro/99). $\square$ cultura do milho, $\square$ outra cultura que não o milho ou plantas daninhas e $\square$ preparo do solo. 


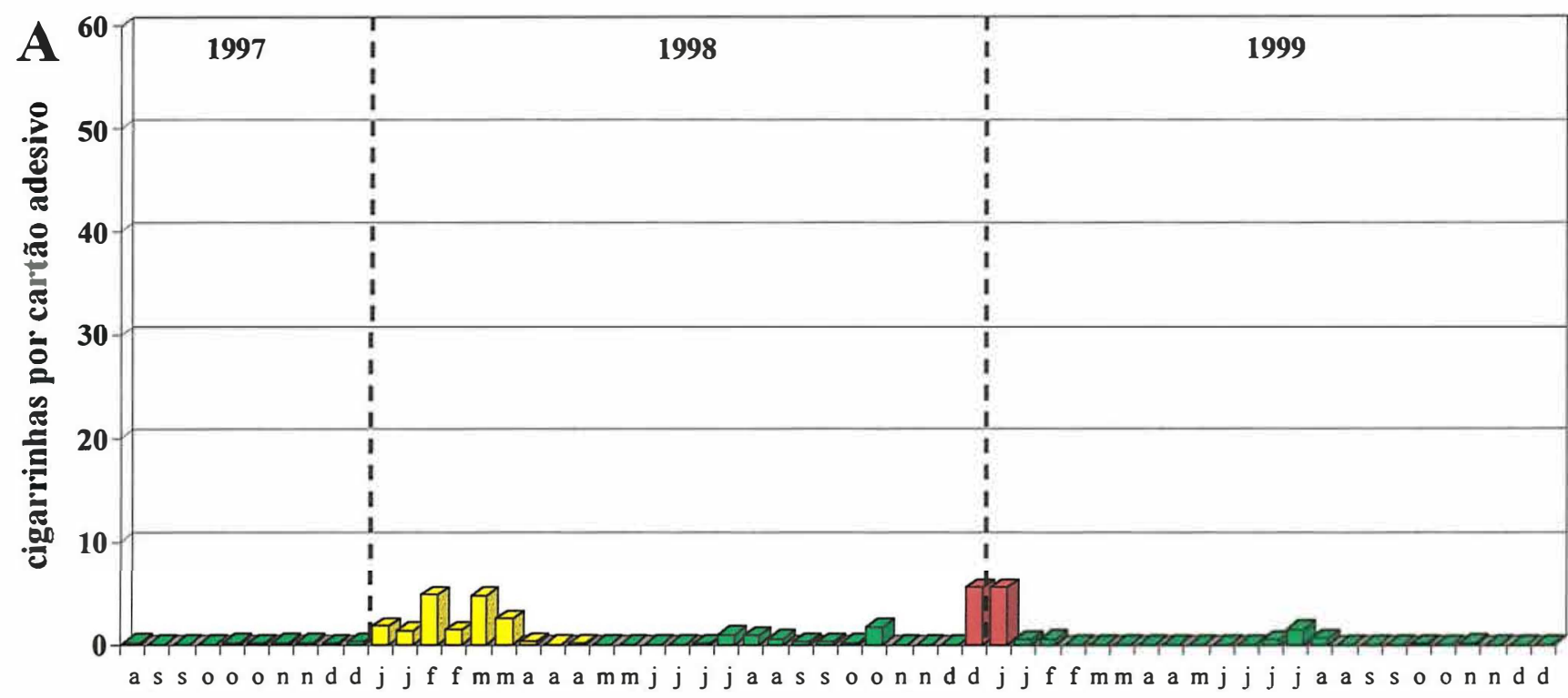
mês

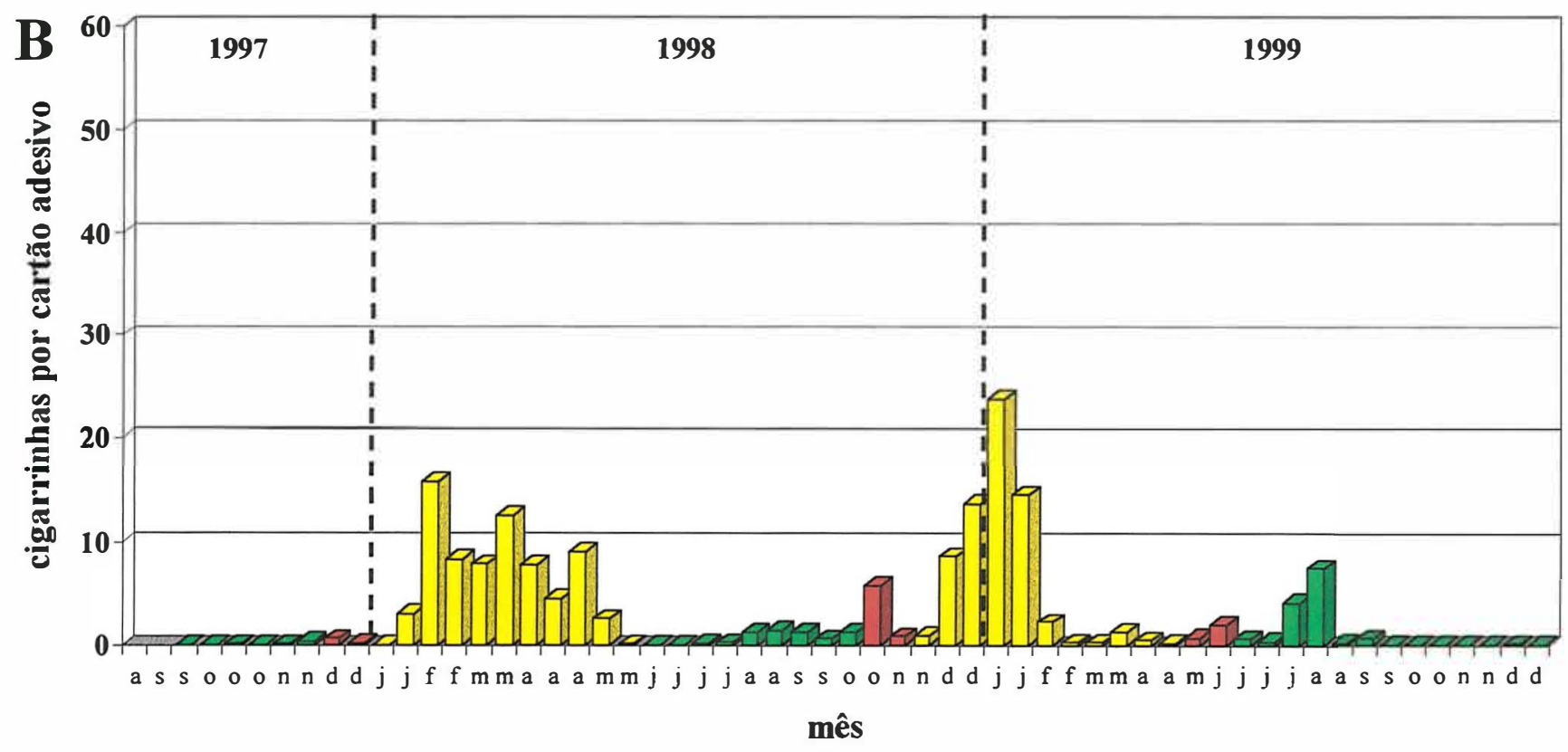

Figura 4. Número médio de adultos de Dalbulus maidis coletados por cartão adesivo amarelo no município de Anastácio/MS, em áreas onde o milho não era plantado há pelo menos 5 anos: A) área III (período de agosto/97 a dezembro/99) e B) área IV (período de setembro/97 a dezembro/99). $\square$ cultura do milho, $\square$ outra cultura que não o milho ou plantas daninhas e $\square$ preparo do solo. 


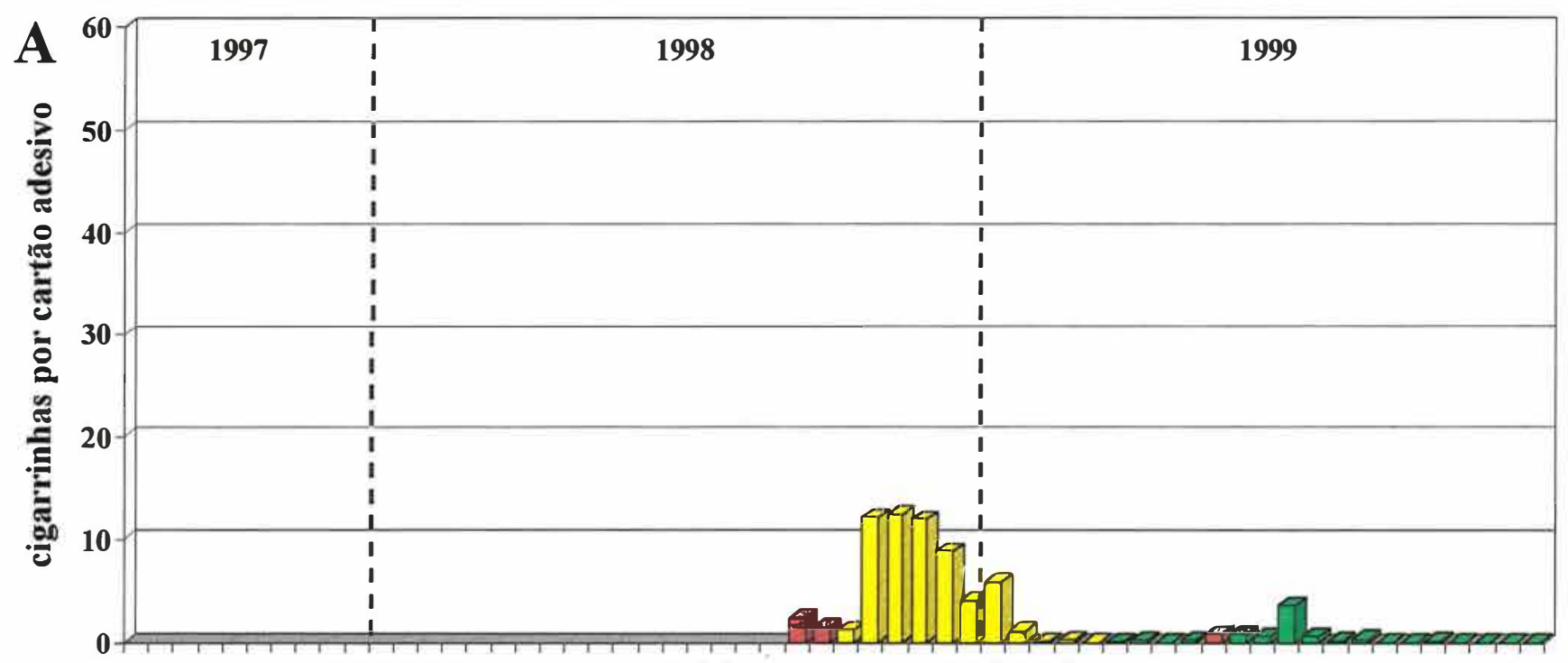

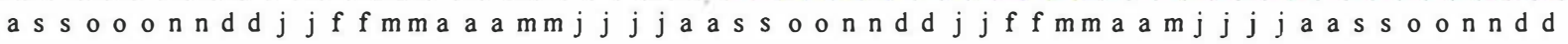
mês

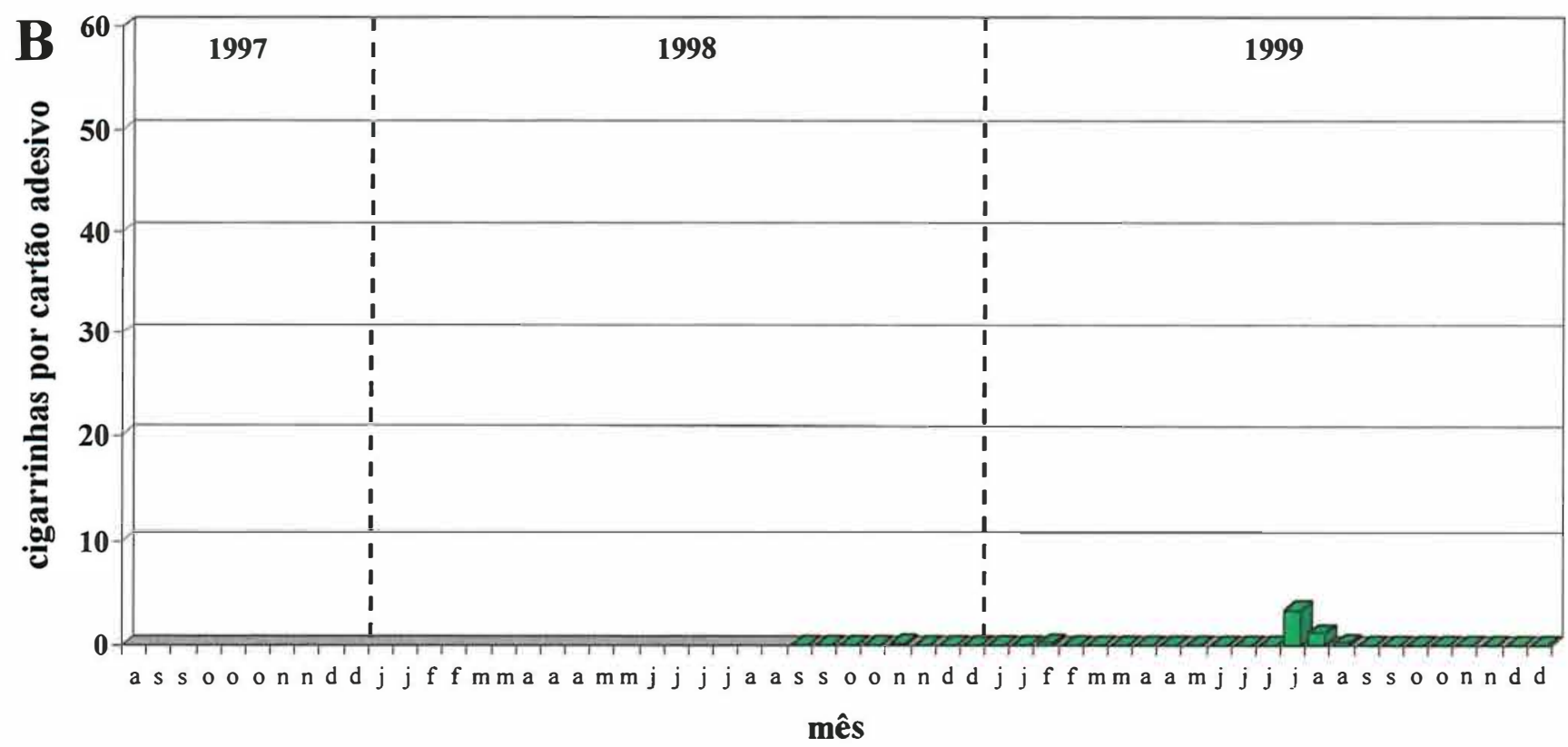

Figura 5. Número médio de adultos de Dalbulus maidis coletados por cartão adesivo amarelo no município de Anastácio/MS, em áreas onde o milho não era plantado há pelo menos 5 anos: $\mathrm{A}$ ) área $\mathrm{Va}$ e $\mathrm{B}$ ) área $\mathrm{Vb}$ (período de setembro/98 a dezembro/99). $\square$ cultura do milho, $\square$ outra cultura que não o milho ou plantas daninhas e $\square$ preparo do solo. 


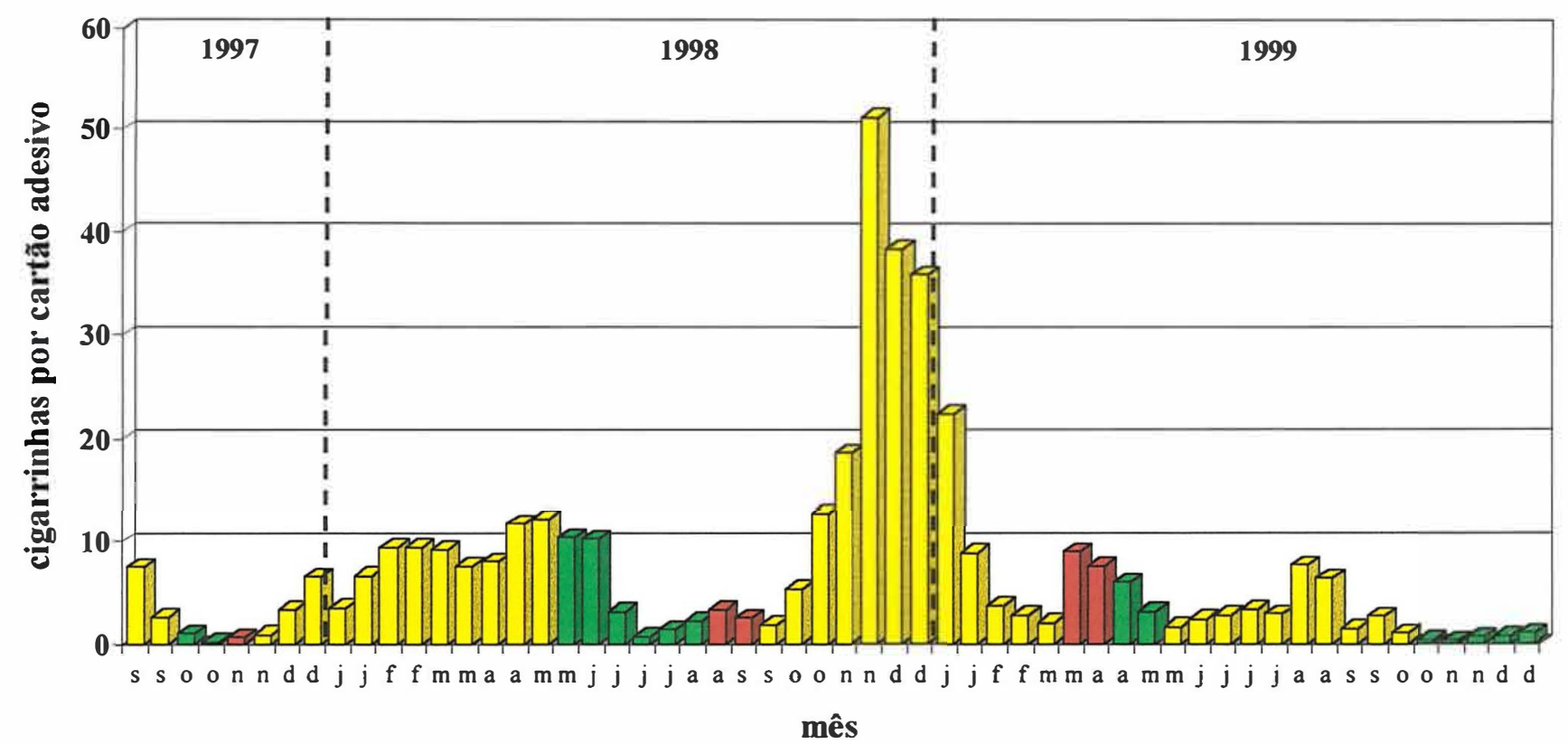

Figura 6. Número médio de adultos de Dalbulus maidis coletados por cartão adesivo amarelo no município de Piracicaba/SP, em área onde o milho era plantado continuamente. Área VI (período de setembro/97 a dezembro/99). $\square$ cultura do milho, $\square$ outra cultura que não o milho ou plantas daninhas e $\square$ preparo do solo. 

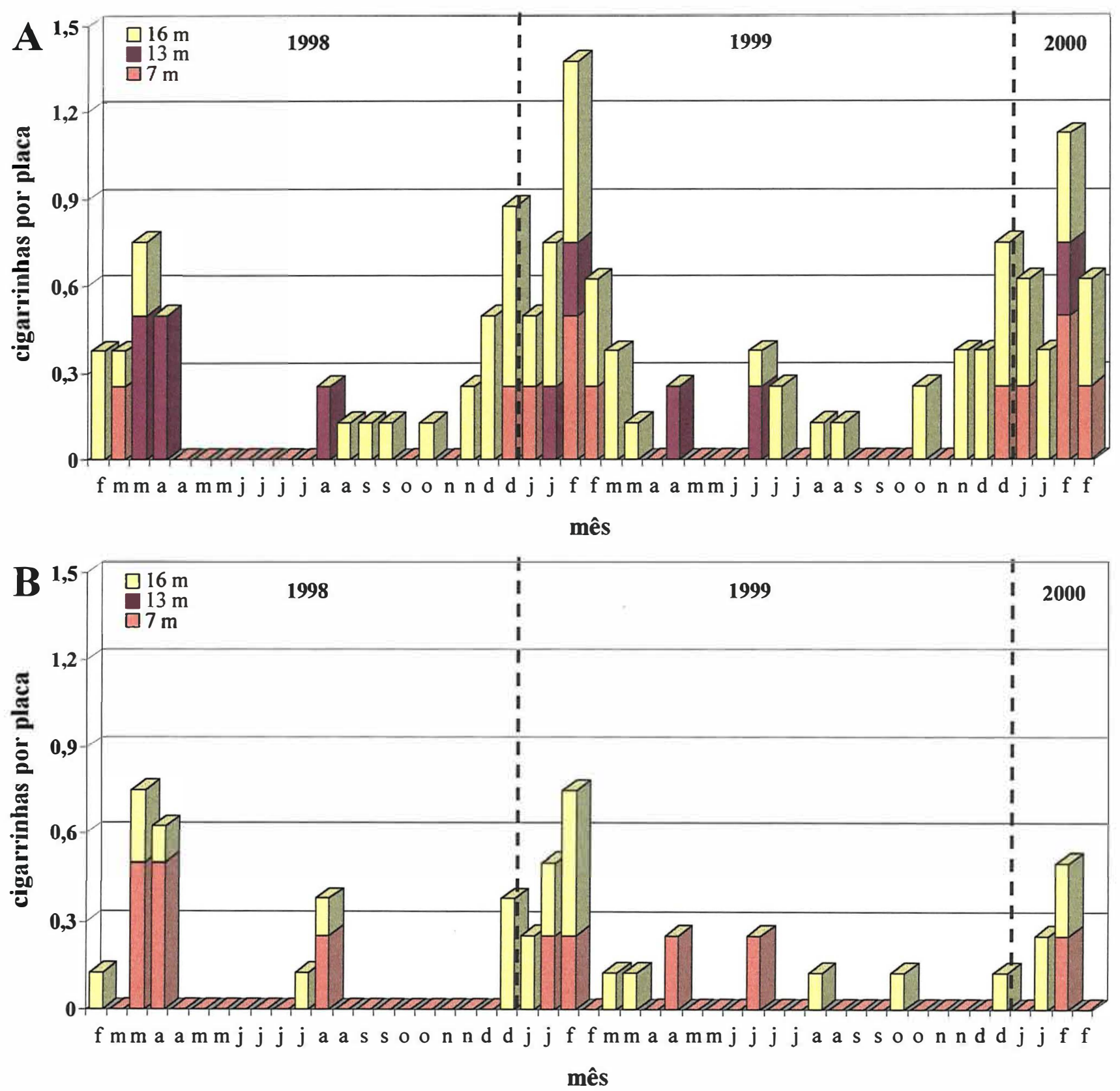

Figura 7. Número médio de adultos de Dalbulus maidis coletados por placa de metal amarelas com cola "sticky", no município de Piracicaba/SP, nas alturas de 7, 13 e $16 \mathrm{~m}$ (período de fevereiro/98 a fevereiro/00). A) fêmeas e B) machos. 


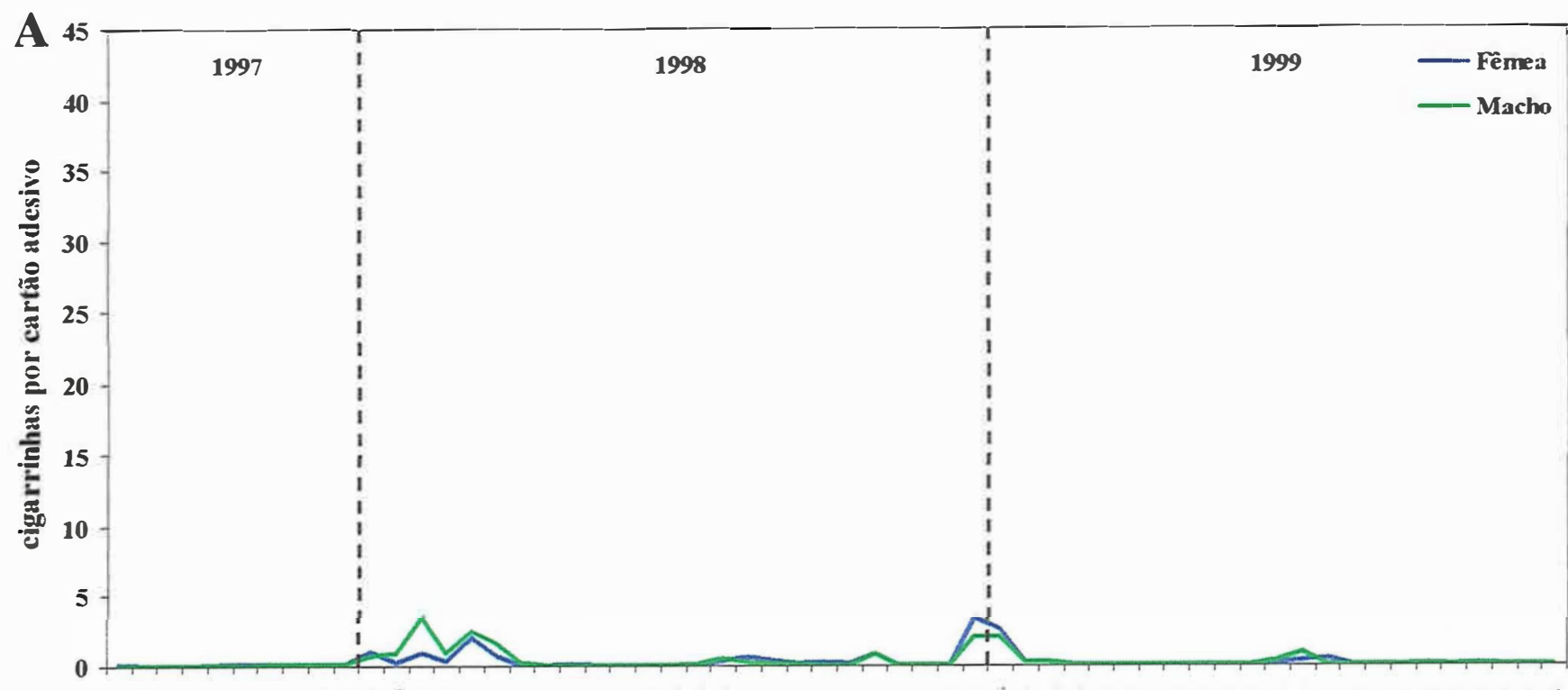

mês

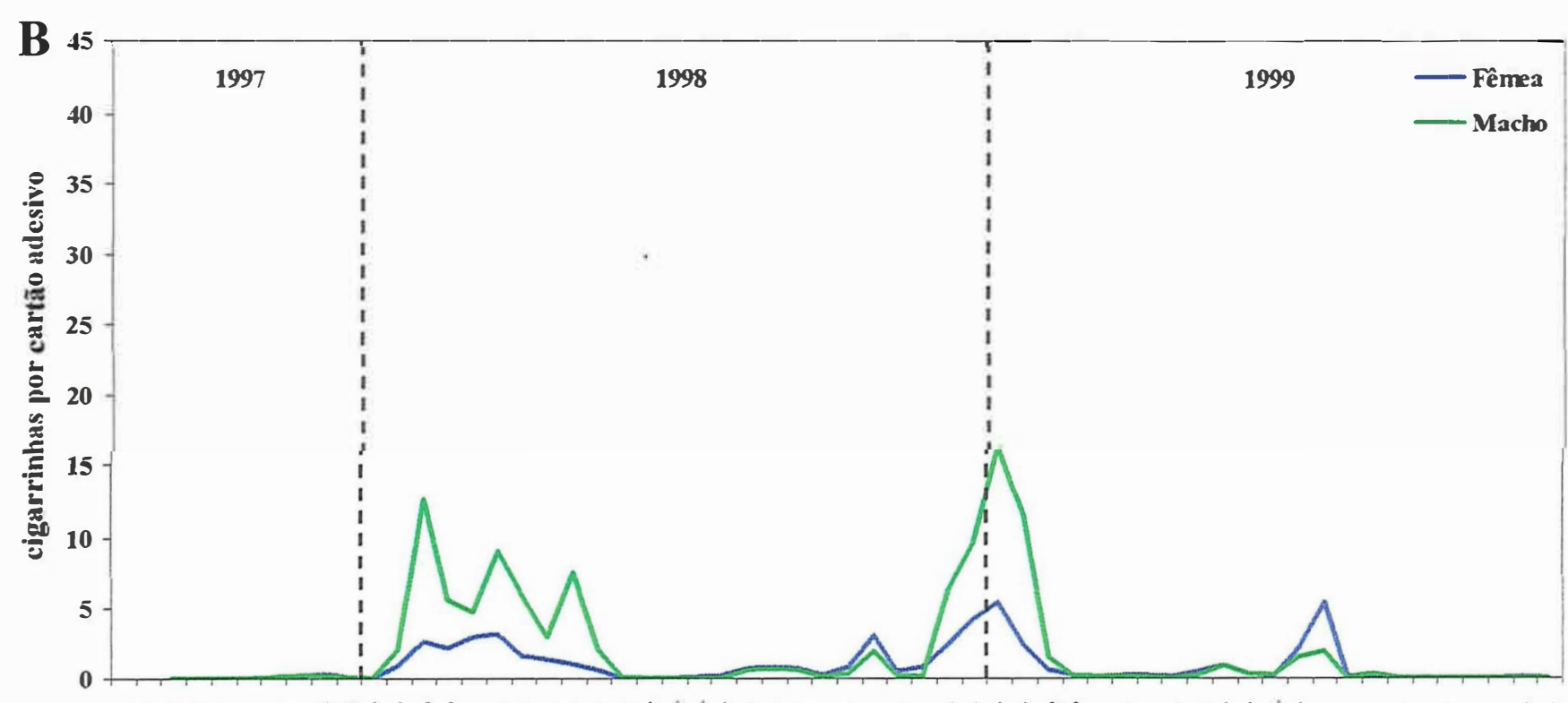

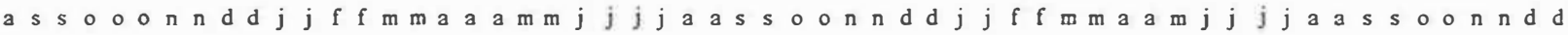

mês

Figura 9. Número médio de adultos fềmeas e machos de Dalbulus maidis coletados por cartão adesivo amarelo no município de Anastácio/MS, em áreas onde o milho não era plantado há pelo menos 5 anos: A) área III (período de agosto/97 a dezembro/99) e B) área IV (período de setembro/97 a dezembro/99). 


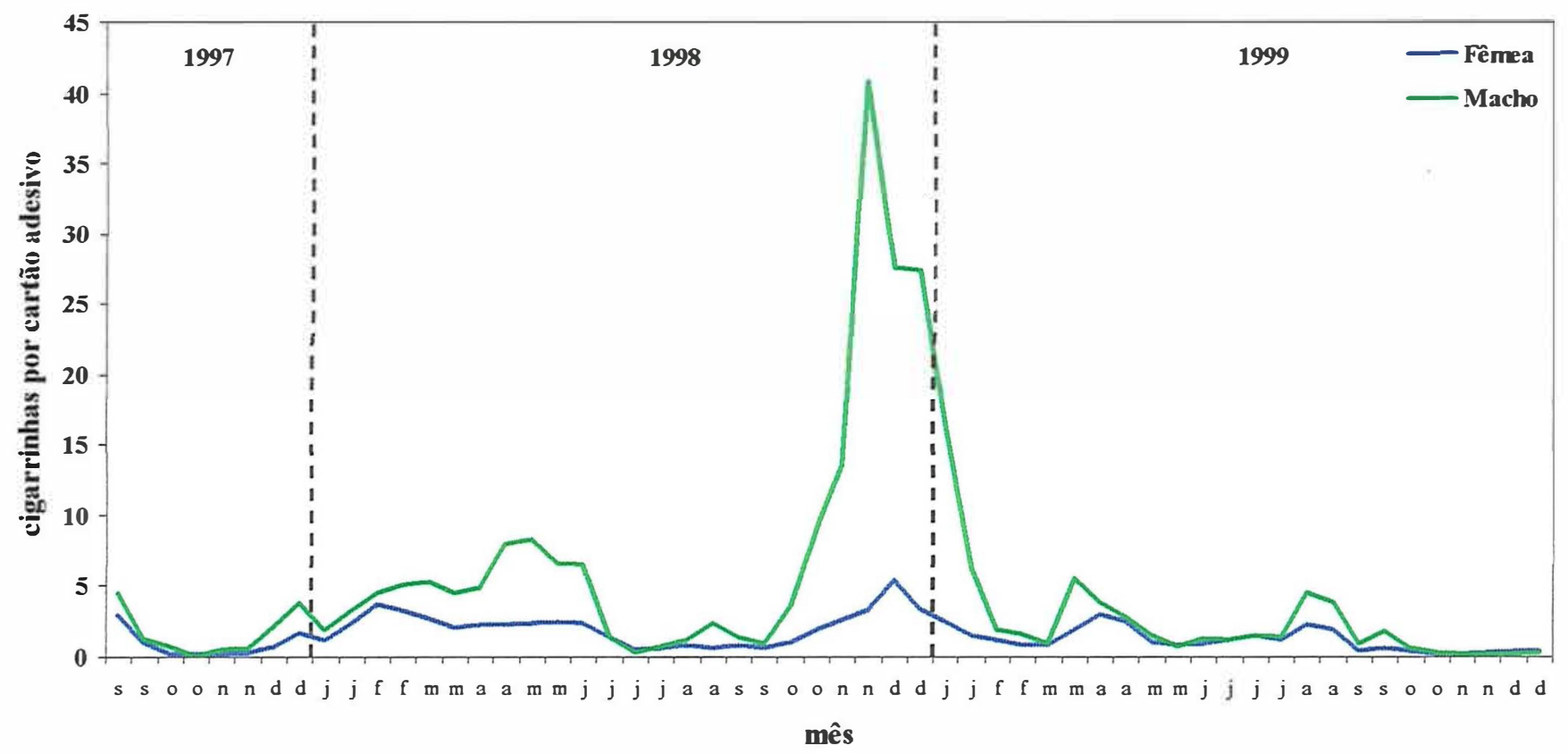

Figura 11. Número médio de adultos fêmeas e machos de Dalbulus maidis coletados por cartão adesivo amarelo no município de Piracicaba/SP, em área onde o milho era plantado continuamente. Área VI (período de setembro/97 a dezembro/99). 

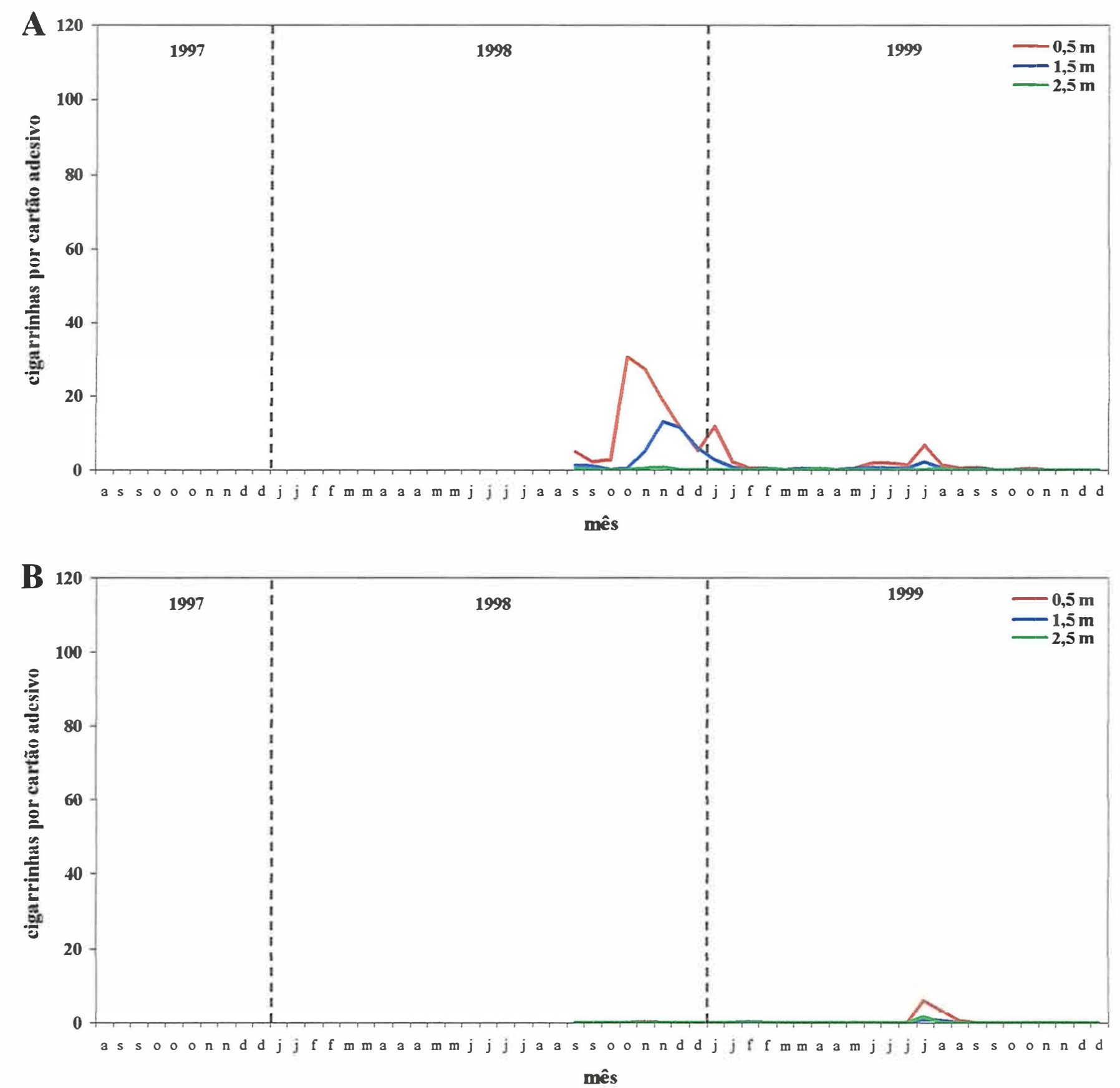

Figura 14. Número médio de adultos de Dalbulus maidis coletados por cartão adesivo amarelo nas alturas de 0,5, 1,5 e 2,5 m, no município de Anastácio/MS, em áreas onde o milho não era plantado há pelo menos 5 anos: A) área Va e B) área $\mathrm{Vb}$ (período de setembro/98 a dezembro/99). 


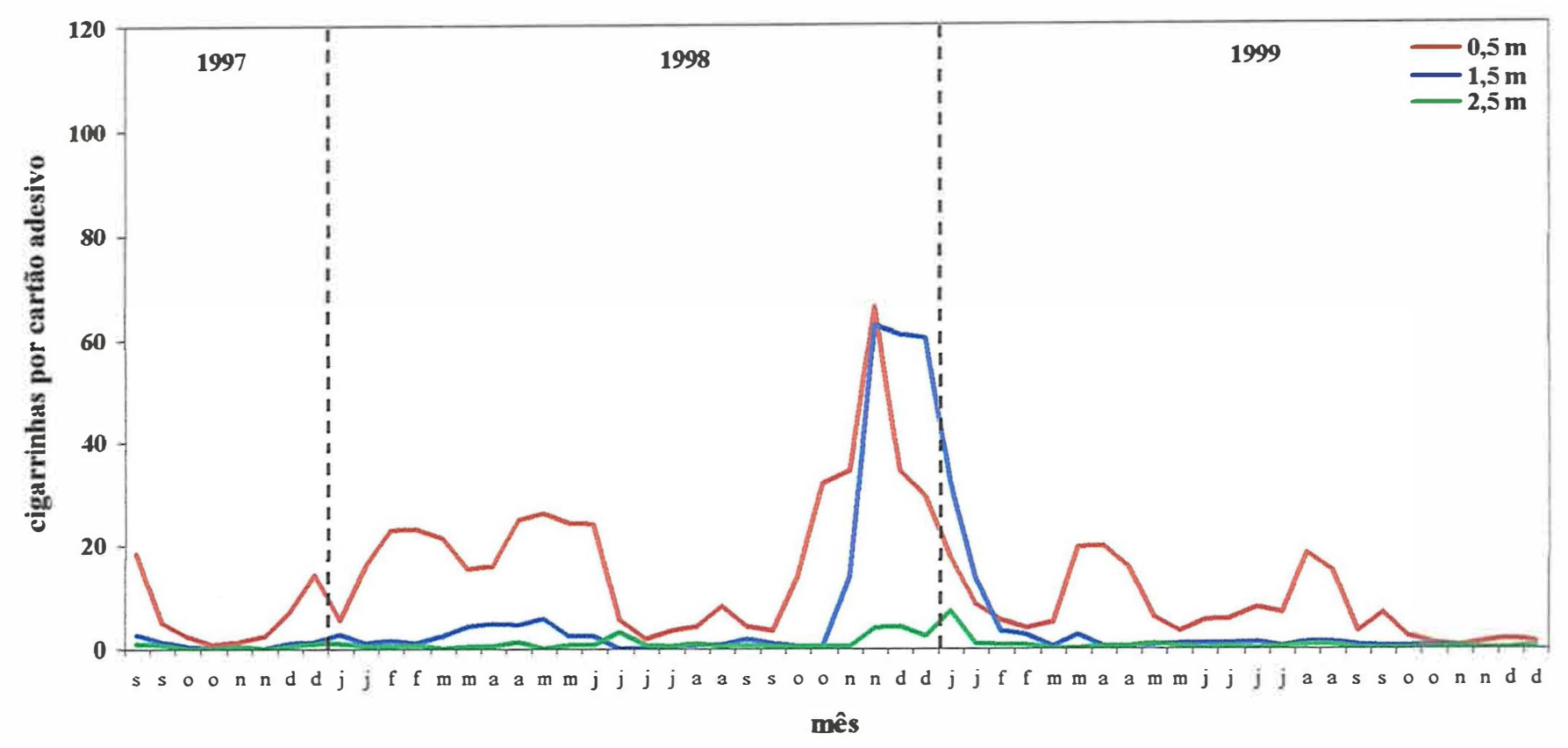

Figura 15. Número médio de adultos de Dalbulus maidis coletados por cartão adesivo amarelo nas alturas de $0,5,1,5$ e $2,5 \mathrm{~m}$, no município de Piracicaba/SP, em área onde o milho era plantado continuamente. Área VI (período de setembro/97 a dezembro/99).

A quantidade de espécimes de D. maidis coletados também variou em relação à posição em que as armadilhas foram dispostas nas áreas. Em certas áreas houve uma ou mais posições em que a coleta foi maior que nas outras; no entanto, esta maior captura não se deu somente nesta posição em determinado período, ou seja, sempre que houve o aumento na coleta de cigarrinhas nestas posições aumentou-se também a captura nas outras posições, comparativamente em níveis menores (Figuras 16-19). Com relação à orientação dos cartões, não foram observadas diferenças entre as coletas no lado norte ou lado sul (Figuras 20-23). 

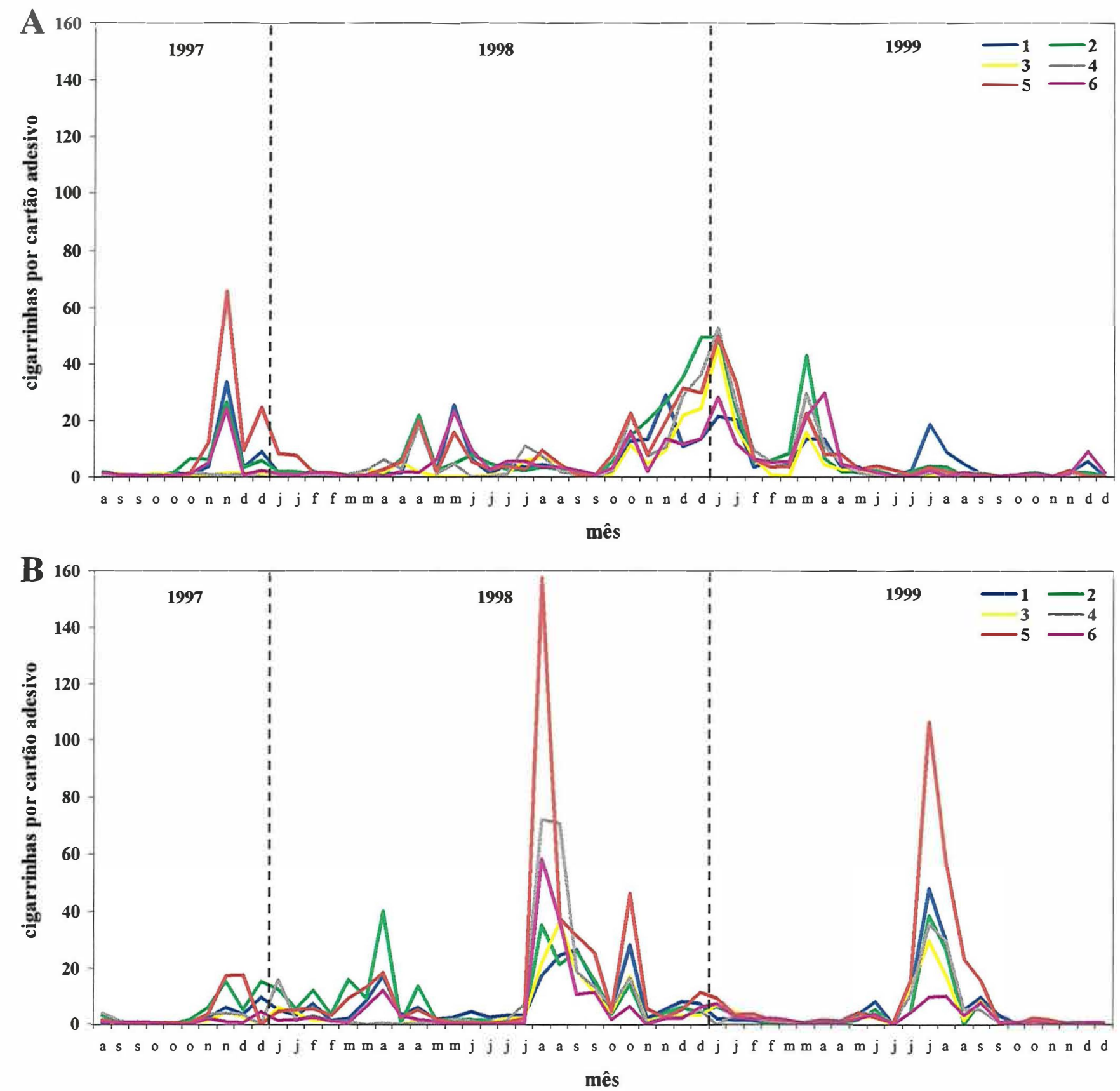

Figura 16. Número médio de adultos de Dalbulus maidis coletados por cartão adesivo amarelo em diferentes posições (ver Figura 2), no município de Anastácio/MS, em áreas onde o milho era plantado uma vez por ano: A) área I e B) área II (período de agosto/97 a dezembro/99). 


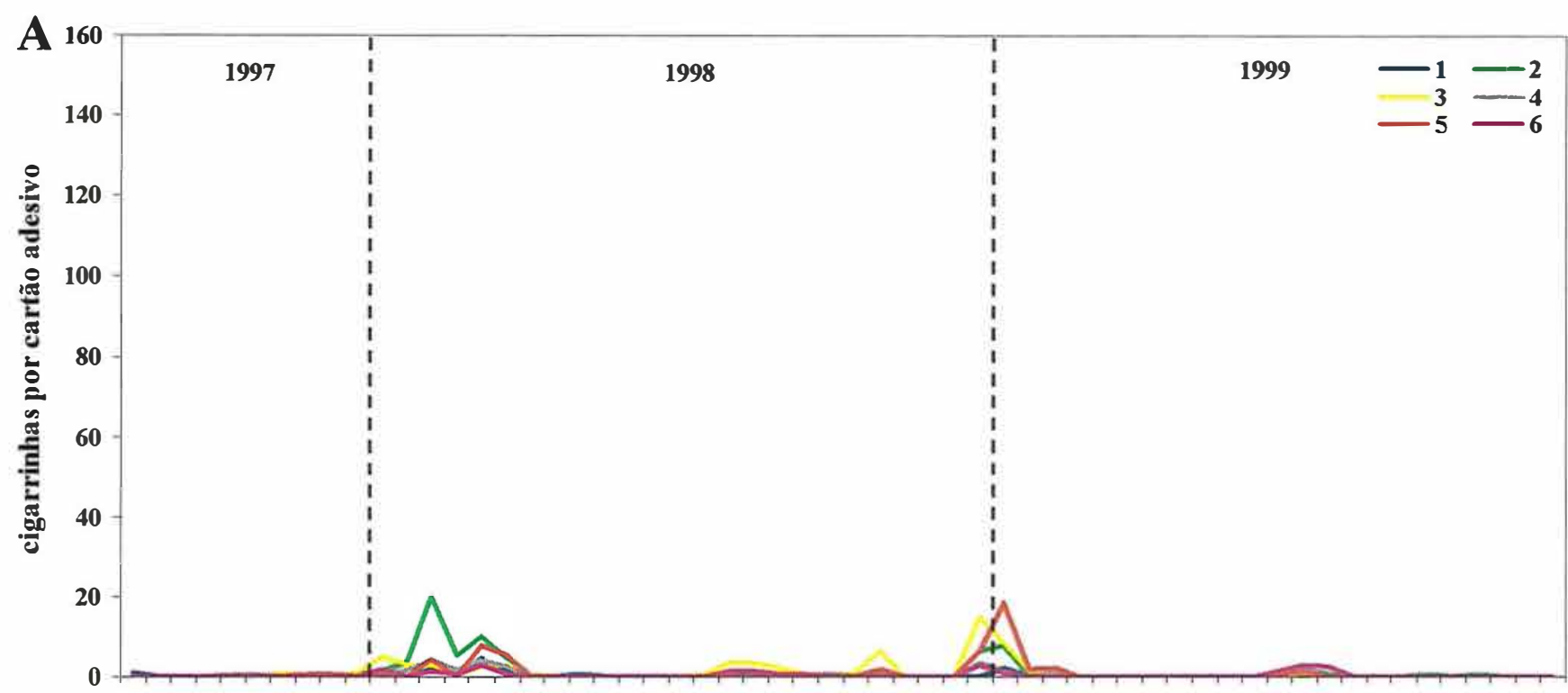

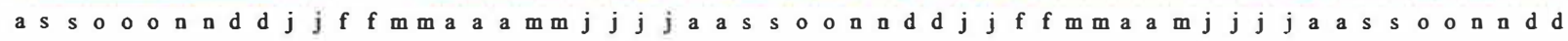
mês

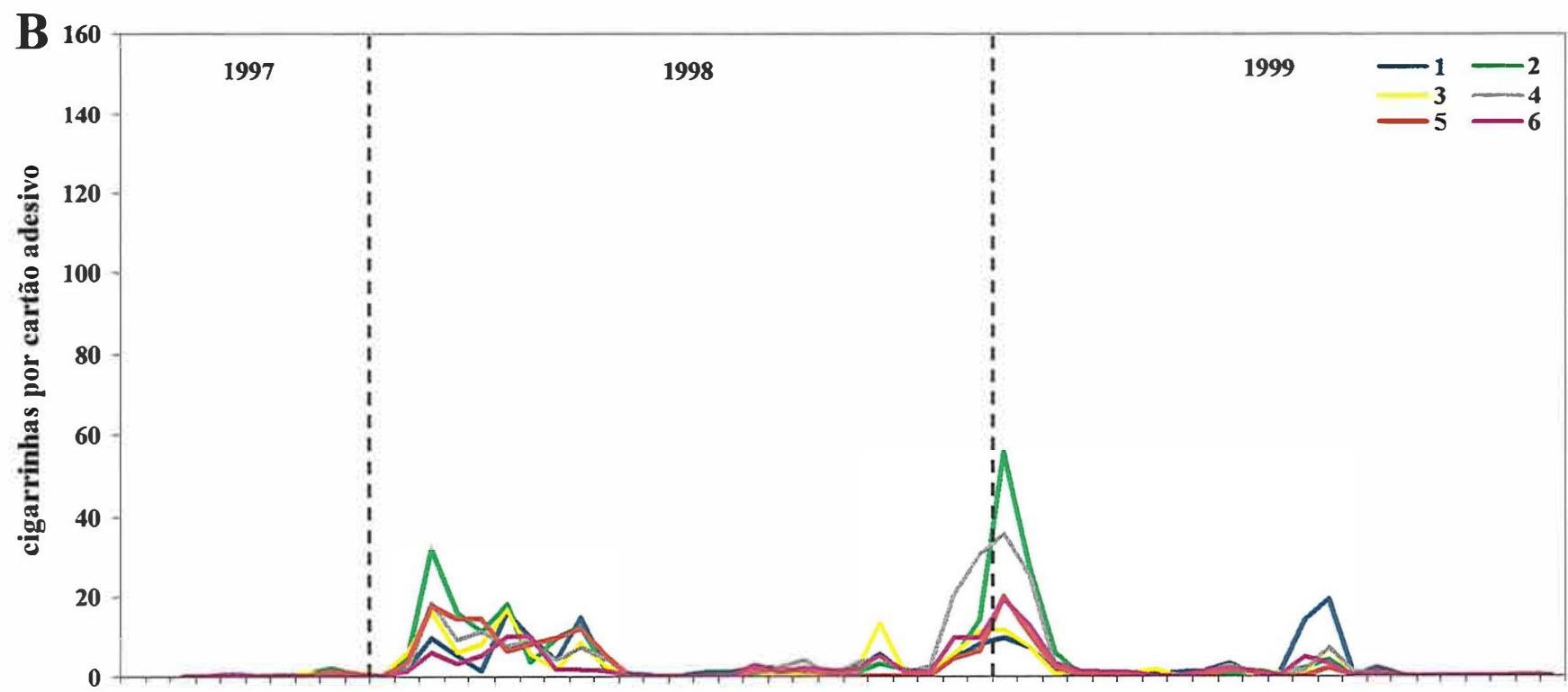

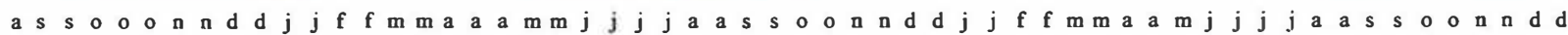

mês

Figura 17. Número médio de adultos de Dalbulus maidis coletados por cartão adesivo amarelo em diferentes posições (ver Figura 2), no município de Anastácio/MS, em áreas onde o milho não era plantado há pelo menos 5 anos: A) área III (período de agosto/97 a dezembro/99) e B) área IV (período de setembro/97 a dezembro/99). 

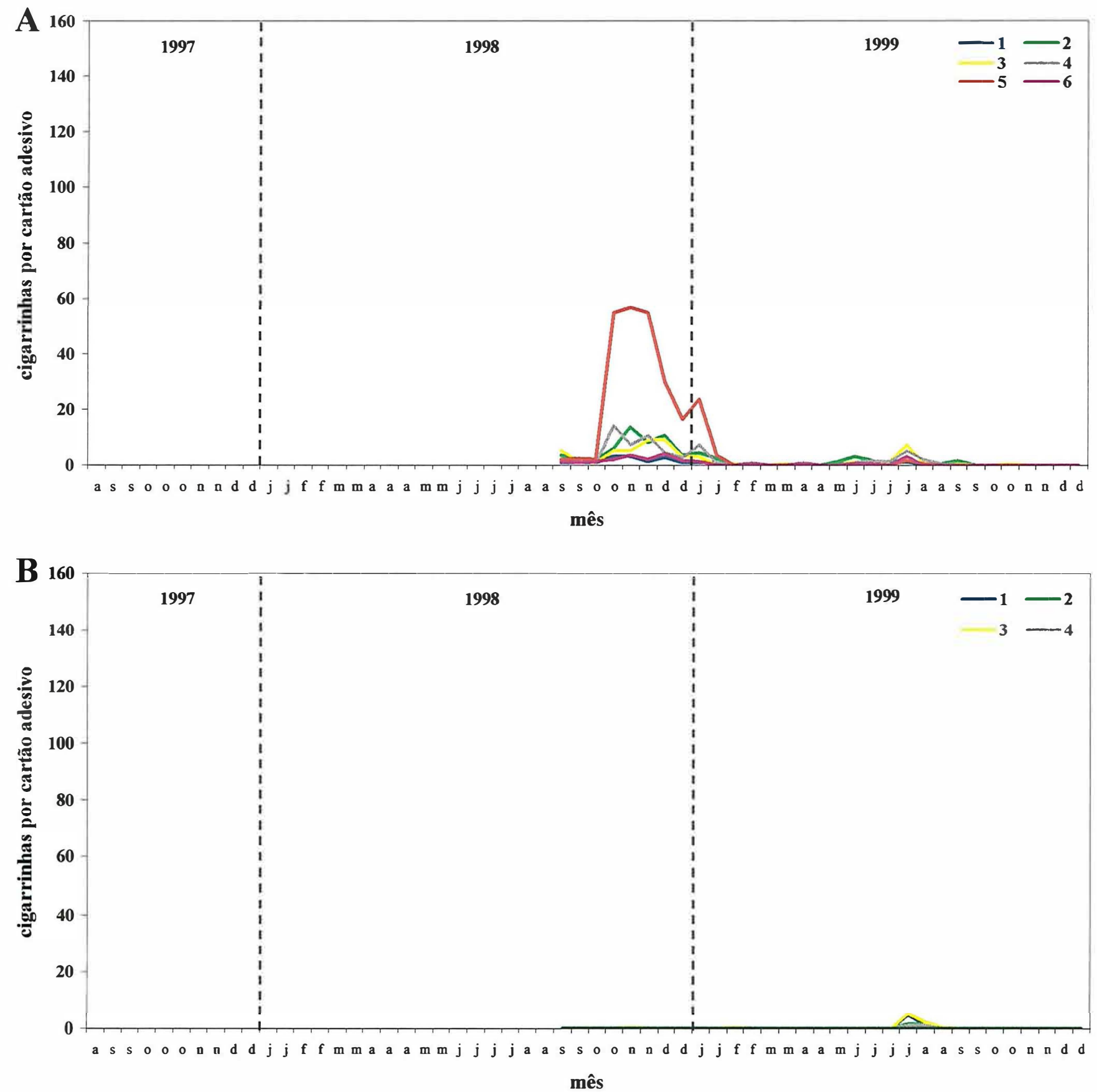

Figura 18. Número médio de adultos de Dalbulus maidis coletados por cartão adesivo amarelo em diferentes posições (ver Figura 2), no município de Anastácio/MS, em áreas onde o milho não era plantado há pelo menos 5 anos: $\mathrm{A})$ área $\mathrm{Va} \mathrm{e} \mathrm{B}$ ) área $\mathrm{Vb}$ (período de setembro/98 a dezembro/99). 


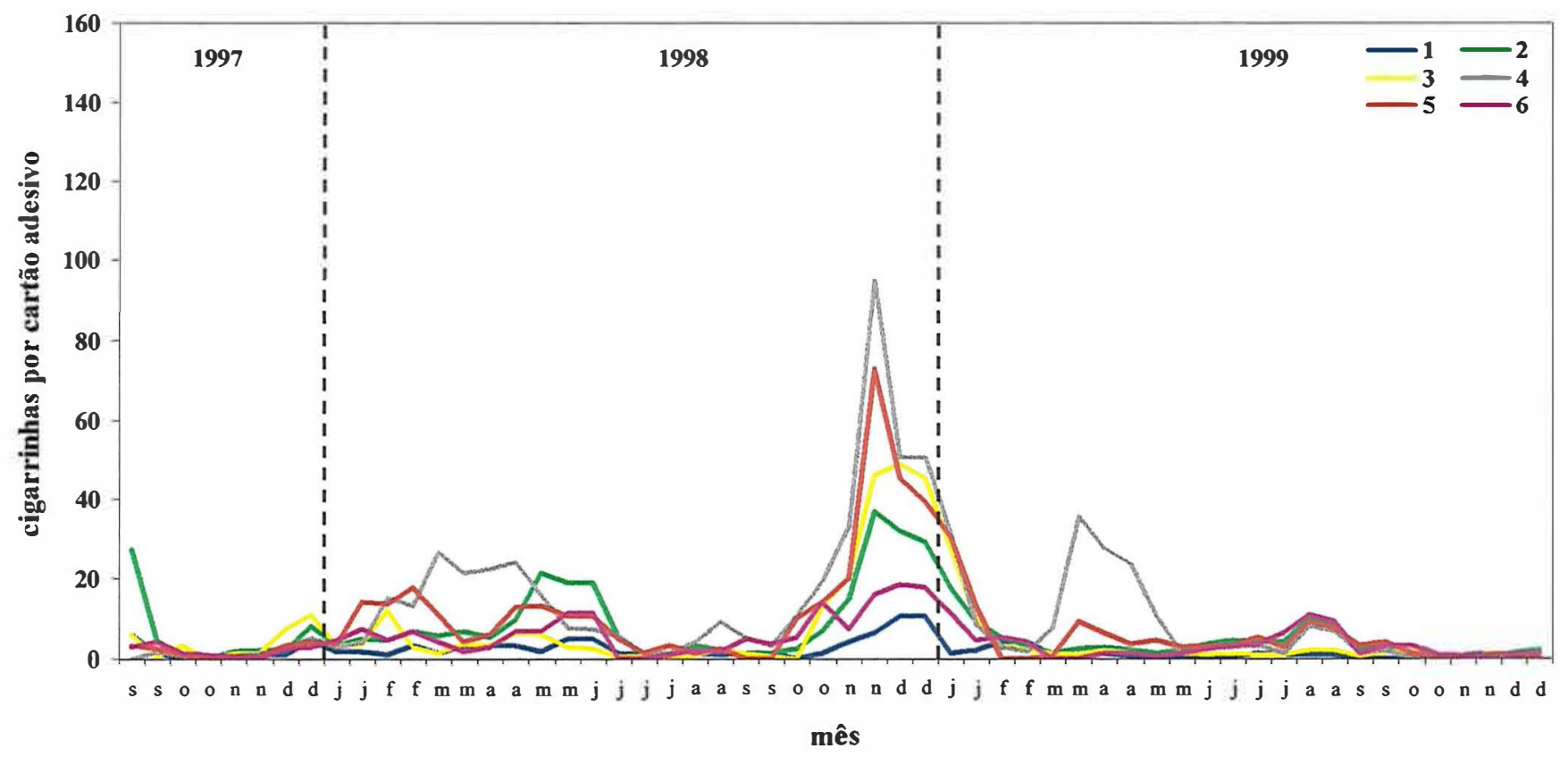

Figura 19. Número médio de adultos de Dalbulus maidis coletados por cartão adesivo amarelo em diferentes posições (ver Figura 2), no município de Piracicaba/SP, em área onde o milho era plantado continuamente. Área VI (período de setembro/97 a dezembro/99). 


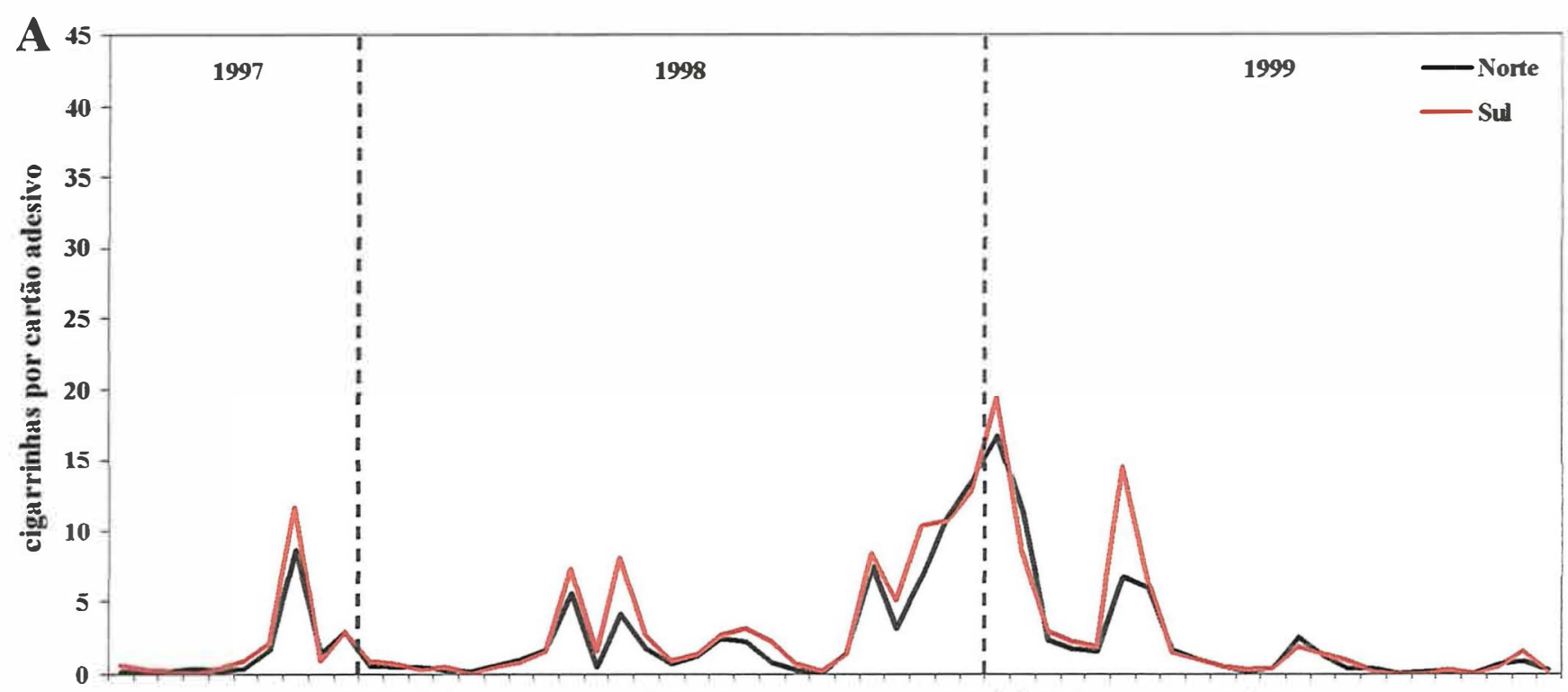

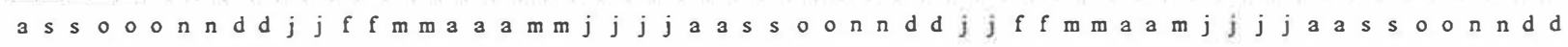
mês

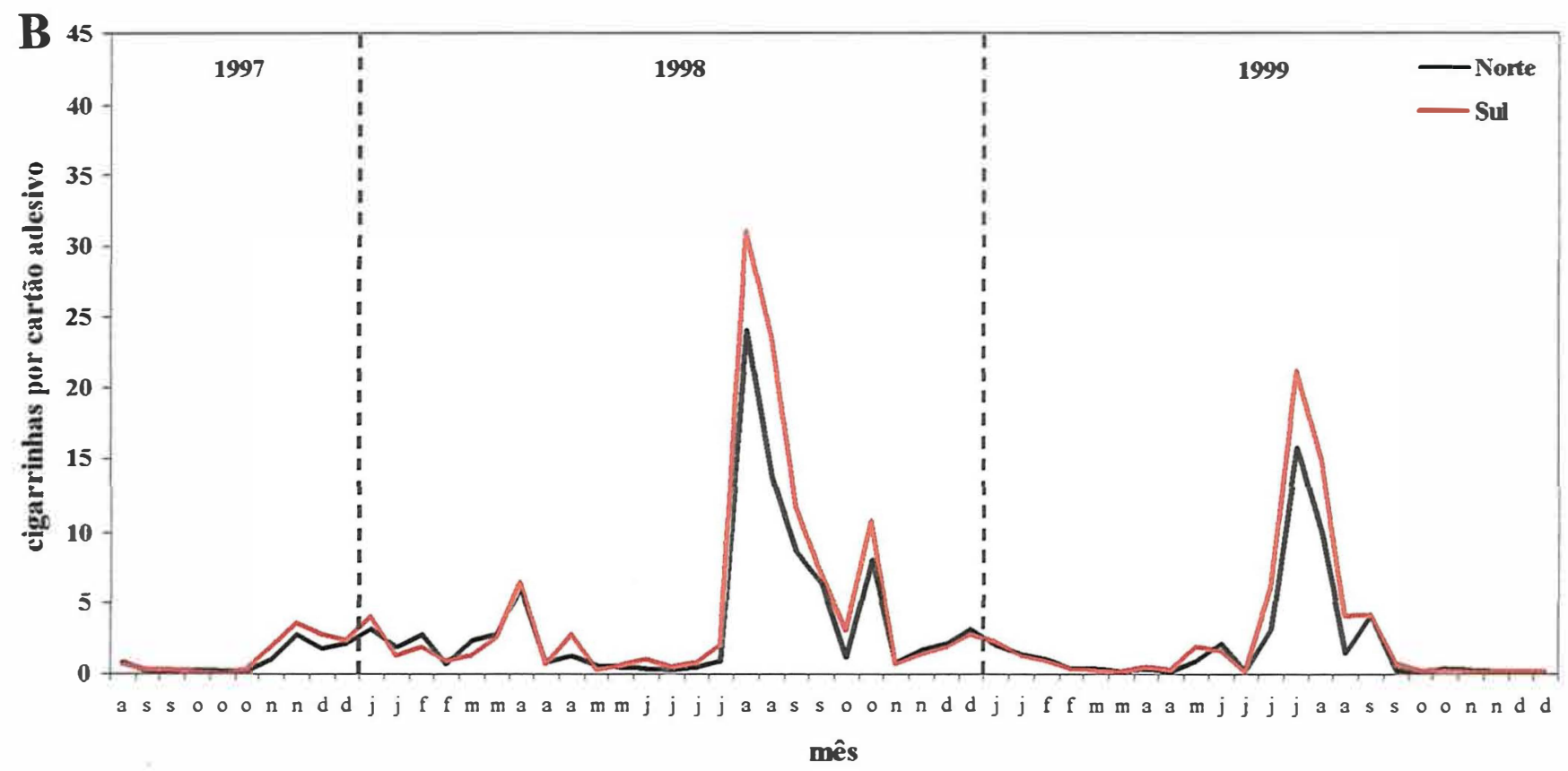

Figura 20. Número médio de adultos de Dalbulus maidis coletados nas faces norte e sul dos cartões adesivos amarelos, no município de Anastácio/MS, em áreas onde o milho era plantado uma vez por ano: A) área I e B) área II (período de agosto/97 a dezembro/99). 

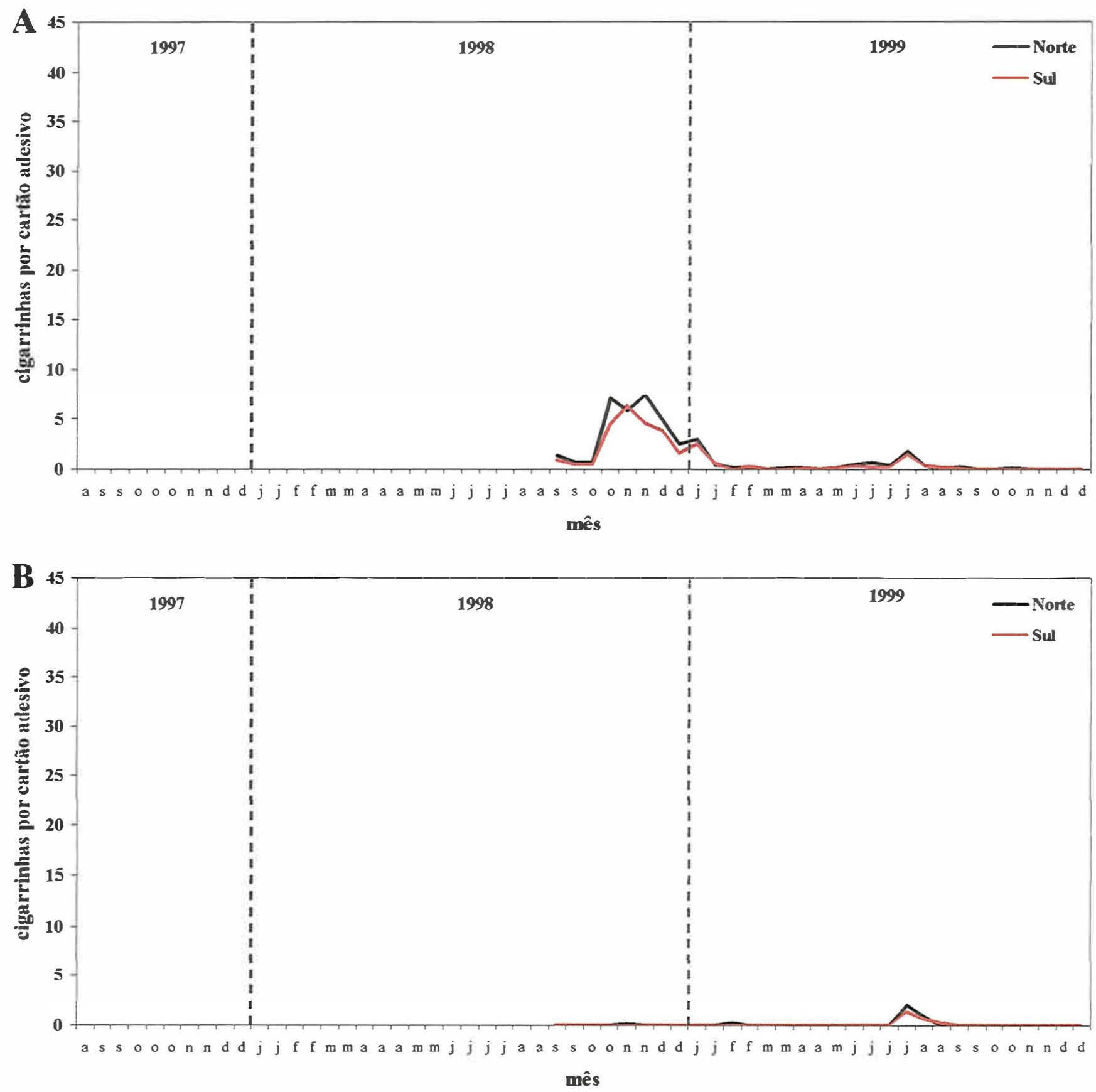

Figura 22. Número médio de adultos de Dalbulus maidis coletados nas faces norte e sul dos cartões adesivos amarelos, no município de Anastácio/MS, em áreas onde o milho não era plantado há pelo menos 5 anos: A) área Va e B) área $\mathrm{Vb}$ (período de setembro/98 a dezembro/99). 


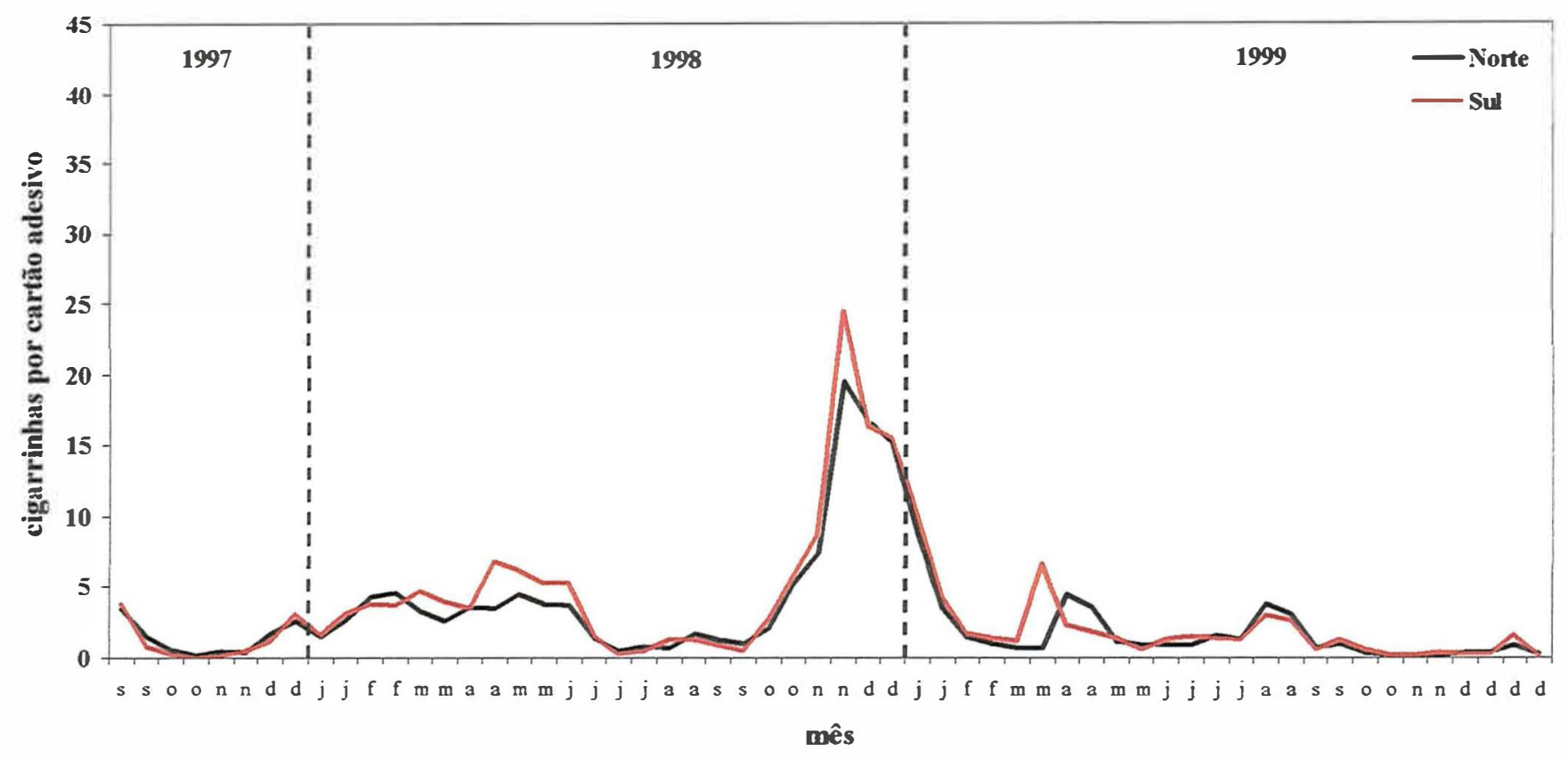

Figura 23. Número médio de adultos de Dalbulus maidis coletados nas faces norte e sul dos cartões adesivos amarelos, no município de Piracicaba/SP, em área onde o milho era plantado continuamente. Área VI (período de setembro/97 a dezembro/99).

Nas áreas I, II e Va, cartões adesivos amarelos foram também colocados em quatro pontos no interior de matas adjacentes às áreas experimentais (Figura 2), nas alturas de 0,5 e $1,5 \mathrm{~m}$. Um total de 584 cartões foram avaliados durante todo o estudo e apenas três espécimes da cigarninha-do-milho foram coletadas nestes pontos. Durante a entressafra do milho nas áreas situadas em Anastácio/MS, foram realizadas buscas minuciosas de possíveis hábitats alternativos, ou mesmo de outras plantas (principalmente gramíneas) que servissem como hospedeiros de D. maidis, pelo menos para a alimentação. A observação visual de locais próximos a cursos d'água, bem como o exame de restos culturais e de vegetação de grande porte adjacentes às áreas experimentais, não nos permitiu a observação de adultos ou ninfas de D. maidis. Coletas realizadas com rede de varredura e com succionador motorizado nas gramíneas e outros tipos de vegetação nas bordas dos talhões experimentais proporcionaram a coleta de $>1.800$ cicadelídeos, no entanto, nenhum espécime da cigarrinha-do-milho foi encontrado. Por outro lado, alguns espécimes de D. maidis foram coletados com rede de 
varredura na área II, em setembro de 1999, quando a cobertura vegetal (melancia) representava aproximadamente $6 \%$ da área e o restante (94\%) do solo descoberto.

\subsection{DISCUSSÃO}

O município de Anastácio/MS foi escolhido para a realização deste estudo por estar dezenas de quilômetros distante de grandes áreas produtoras de milho, e se caracterizar por um longo contínuo de pastagens, onde o milho, hospedeiro primário de D. maidis, é plantado em pequenas áreas, uma única vez ao ano, havendo um período prolongado de entressafra (6-7 meses). Além disso, a região apresenta muitas propriedades rurais onde o milho não é plantado há muitos anos, constituídas de pastagens perenes. Por outro lado, a área situada no município de Piracicaba/SP possui característica de um hábitat mais estável para a cigarrinha-do-milho, pois nela o milho vinha sendo cultivado durante todo ano, sob irrigação, em áreas vizinhas ao talhão experimental, propiciando uma fonte contínua de recurso alimentar.

O primeiro estudo de flutuação populacional de $D$. maidis foi realizado por Barnes (1954) em Jaloxtoc, México, em área onde o milho foi plantado em pequenas parcelas durante um ano. Amostragens semanais foram realizadas utilizando-se uma caixa de coleta e apenas as fêmeas foram computadas. Larsen et al. (1992) estudaram a flutuação populacional de D. maidis em Jalisco, México, através de coletas com cartões adesivos amarelos dupla face, trocados a cada 1-2 semanas, no período de um ano e meio, em três áreas com características distintas. Estes dois estudos mostraram que no México as maiores populações da cigarrinha-do-milho ocorrem quando se planta o milho nos meses de outubro a fevereiro (estação seca), com coletas muito baixas no período de março a setembro (estação chuvosa). Estes resultados mostraram uma certa sincronia do crescimento da população de $D$. maidis com o desenvolvimento da cultura do milho (Todd et al., 1991). 
No presente estudo, D. maidis pôde ser capturada durante todo ano, em algumas áreas em níveis populacionais bastante altos mesmo quando não havia milho no campo, como por exemplo no período de entressafra de abril a outubro dos anos de 1998 e 1999, nas áreas I e II de Anastácio/MS (Figuras 3A e B). A presença de D. maidis nestas áreas durante a entressafra pode ser atribuída, pelo menos em parte, à presença abundante de rebrotas de milho, que cresceram de sementes caídas ao solo depois da colheita, em meio à cultura subseqüente, no caso o feijão ou plantas daninhas. No cartucho destas rebrotas foi possível a observação de número significativo de $D$. maidis. Rebrotas de milho são comuns principalmente em áreas de pequenos agricultores, onde a utilização de herbicidas não é prática comum.

No caso da área VI, além das rebrotas, o fato de haver sempre plantios de milho próximos à área do experimento pode ter contribuído para a coleta da cigarrinhado-milho no curto período de entressafra. Na região de Anastácio/MS, o período de entressafra (abril a outubro) se caracteriza por baixa precipitação (principalmente de junho a agosto), e ao contrário do que ocorre no México, as temperaturas médias neste período, apesar de mais baixas do que as de novembro a março, são superiores a $20^{\circ} \mathrm{C}$; essas características fornecem uma condição climática favorável para D. maidis no caso da presença do milho. O maior número de espécimes coletados nas áreas I, II e III (Tabela 1) foi provavelmente devido ao maior tamanho de suas áreas de cultivo ( $>4$ ha); nas áreas III, IV e Va o talhão de cultivo se restringiu a $\approx 2000 \mathrm{~m}^{2}$. No caso da área VI, a presença contínua de milho nos talhões adjacentes também pode ter contribuído para 0 maior nível de coleta dentre todas as áreas estudadas.

Se as populações de $D$. maidis em Anastácio/MS são mantidas no período de entressafra as custas de rebrotas, como se explica o fato da cigarninha-do-milho ter aparecido na área $\mathrm{Vb}$ (Figura 5B), onde não se plantou o milho (portanto não havia rebrotas), e em número elevado em todas as áreas por ocasião do preparo do solo (Figuras 3-6), quando as rebrotas são eliminadas? A resposta para esta pergunta pode ser a migração a longas distâncias. Alguns estudos têm apontado uma possível estratégia migratória para $D$. maidis. Nault (1990) salientou que a migração pode desempenhar papel importante no ciclo de vida de espécies que utilizam hospedeiros efêmeros como é 
o milho para $D$. maidis. As cigarninhas adultas que aparecem subitamente em plântulas de milho no México Central provavelmente tenham origem em milho irrigado plantado em regiões de baixa altitude durante a entressafra da cultura (Nault, 1985). Taylor et al. (1993) estudaram a atividade de vôo da cigarrinha-do-milho e observaram que fềmeas respondem diretamente à condição da planta hospedeira e machos ao nível de luminosidade. Segundo estes autores, a cigarrinha $D$. maidis possui um comportamento consistente com vôos migratórios de inverno coincidindo com correntes de vento que poderiam levá-la para regiões onde se cultiva milho de inverno.

Os nossos resultados sustentam a hipótese de uma estratégia migratória para D. maidis, fornecendo algumas evidências adicionais, tais como o aparecimento súbito da cigarrinha-do-milho em Anastácio/MS, em áreas de pastagens onde o milho não havia sido plantado há anos e localizadas a dezenas de $\mathrm{km}$ de pequenas áreas de milho no município, como por exemplo as áreas I e II. Os picos populacionais que ocorreram simultaneamente em todas as áreas em Anastácio/MS nos meses de julho e agosto de 1998 e 1999, inclusive na área $\mathrm{Vb}$ onde o milho não chegou a ser plantado e cuja área permaneceu coberta por pastagem, representa outra evidência. Vale salientar que no ano de 1999 procurou-se fazer um controle das rebrotas na entressafra do milho em todas as áreas, mas mesmo assim quantidades apreciáveis de cigarninhas foram coletadas. $\mathrm{O}$ fenômeno de migração a longas distâncias tem sido bem documentado para outras cigarrinhas como Empoasca fabae (Harris) (Carlson et al., 1992; Pienkowiski \& Medler, 1964), Nilaparvata lugens Stål (Holt et al., 1996) e Macrosteles quadrilineatus Forbes (Hoy et al., 1992).

Os meses de julho e agosto marcam a época de colheita do milho safrinha, que é plantado nos meses de fevereiro a abril, após a colheita da safra convencional em diversas regiões como norte de São Paulo, Triângulo Mineiro, Paraná, Goiás e Mato Grosso. Nós especulamos que as populações de D. maidis capturadas em Anastácio/MS, nos meses de inverno (julho/agosto) podem estar vindo de regiões produtoras de milho safrinha situadas a dezenas ou centenas de quilômetros, após a perda de seu hospedeiro. Estas evidências concordam com as conclusões de Taylor et al. (1993) de que D. maidis é um migrante de inverno, cuja atividade de vôo, principalmente de fềmeas, está 
relacionada à condição da planta hospedeira, e de Larsen et al. (1992) que observaram picos de coleta da cigarrinha-do-milho no inverno, logo após a seca do milho, concluindo que estes eram vôos de exôdo.

Alguns autores têm relatado o aparecimento súbito de adultos D. maidis em plântulas de milho, logo após a germinação, no México (Nault, 1985) e América Central (Gámez \& León, 1985). É de relevante importância o fato de termos registrado o aparecimento de populações desta cigarrinha antes das plantas de milho terem germinado, e com raras exceções, aumento significativo no número de ciganinhas capturadas sempre que o solo esteve exposto por práticas como a aração ou gradagem (Figuras 2A e B). Prokopi \& Owens (1983) ressaltaram que o processo de deteç̧ão visual da planta hospedeira por insetos, depende da distância relativa do inseto em relação à fonte de recursos. Para insetos que estejam sendo levados por correntes de vento, distantes da planta hospedeira, o campo visual logo abaixo é perceptível como um padrão de claro e escuro bastante diferente do padrão de intensidade e espectro emitido pelo céu, e este pode lhe proporcionar uma noção de velocidade e direção do movimento. O contraste entre regiões cobertas por vegetação e regiões onde o solo está exposto pode ser detectado por regiões específicas do olho composto de insetos que estejam voando; conseqüentemente, o contraste entre o comprimento de ondas emitido pelo solo e o da vegetação pode ser um importante estímulo para os insetos detectarem à distância, regiões vegetadas e solo exposto (Prokopi \& Owens, 1983). Para muitos afideos, mosca branca e lepidópteros, o pouso na planta hospedeira é mais freqüente quando esta encontra-se rodeada por solo exposto do que por outro tipo de vegetação (Rausher, 1981; Smith, 1976). Para D. maidis este contraste entre a vegetação e solo exposto (aração e/ou gradagem) parece ser um ponto decisivo que determina o local onde as cigarninhas devem pousar. Este fenômeno é particularmente importante quando o contraste entre solo exposto e vegetação coincide com épocas que a cigarrinha-domilho supostamente apresenta grandes fluxos de migração (meses de agosto e julho), o que pode ser confirmado pelo número extremamente alto de cigarrinhas coletadas na área II (Figura 3B) neste período nos anos de 1998 e 1999. Embora o contraste solovegetação potencialize a propensão das cigarrinhas ao pouso em determinada área, este 
não deve ser o único fator condicionante, uma vez que a captura de $D$. maidis aumentou em todas as áreas, inclusive em $\mathrm{Vb}$ (Figura 5B) onde o solo não esteve exposto e o milho não foi plantado.

Já que a migração é um processo onde o dispêndio de energia é grande, o pouso em áreas onde o solo está exposto sem a deteç̧ão visual da planta hospedeira, parece ser uma estratégia de risco para $D$. maidis, que aparentemente envolve enormes populações da cigarrinha para maximizar a possibilidade de encontro de plantas de milho. Por outro lado, resultados encontrados por Larsen et al. (1992) sugerem que $D$. maidis criadas em condições que simularam o final da safra do milho no México, principalmente fềmeas, podem sobreviver um período apreciável de tempo na ausência da planta hospedeira, tendo apenas como recurso disponível a água. Este pode ser um dos mecanismos utilizados por $D$. maidis a espera do surgimento da planta hospedeira adequada, no caso o milho.

A atração de insetos fitófagos diumos pelo amarelo pode ser explicado pela capacidade que estes insetos têm em discriminar o comprimento de onda dominante emitido pela vegetação (com pico entre $500-580 \mathrm{~nm}$ ) de outros objetos (picos menores $500 \mathrm{~nm}$ ou maiores que $580 \mathrm{~nm}$ ) (Kennedy et al., 1961), sendo que o amarelo seria um super estímulo semelhante ao da vegetação, emitindo um pico de energia em um mesmo comprimento de onda em que o espectro visível dos insetos reconhece a vegetação, porém em intensidade muito maior (Prokopi, 1972). Desta forma, o processo de localização da planta hospedeira por $D$. maidis parece seguir o modelo exposto por Prokopi \& Owens (1983), em que durante o vôo, o contraste entre região vegetada e não vegetada seria o estímulo para o pouso do inseto, e estando no solo a uma pequena distância da planta hospedeira, o comprimento de onda dominante de luz refletida seria o fator mais importante de atração. Todd et al. (1990a) estudaram a importância da cor como estímulo para a cigarrinha-do-milho encontrar a planta hospedeira, e observaram que a cor amarela foi a mais atrativa para $D$. maidis. No entanto, outros fatores como compostos químicos voláteis e/ou de contato podem ser necessários para manter a cigarrinha na planta hospedeira e estimular comportamento de alimentação e oviposição (Backus, 1985). Assim, a coleta de um número elevado de D. maidis nas épocas em que 
o solo estava exposto, pode dever-se ao fato de que nesta situação os cartões adesivos amarelos mostravam-se como a única fonte de atração para a cigarrinha-do-milho, levando-as a congregarem maciçamente para os mesmos.

De todas as áreas avaliadas em Anastácio/MS, a área II foi a que apresentou os maiores picos populacionais durante o preparo do solo (Figura 3B). Em relação às áreas de pastagem (III, IV e V), este local teve uma dimensão de área cultivada muito maior, ou seja, maior quantidade de solo esteve exposto sendo o contraste entre área vegetada e não vegetada conseqüentemente maior. Entretanto, em relação à área I que se encontrava relativamente próxima (Figura 1), esta diferença no tamanho da área cultivada praticamente não existiu. Então como se explicaria a diferença de coleta entre as áreas I e II durante os picos populacionais por ocasião do preparo do solo? A resposta pode estar no tipo de preparo do solo. Na área I, o solo para o plantio era preparado incorporando-se restos culturais, onde muita matéria orgânica ficava sobre o solo, enquanto que na área II o preparo deixava o solo completamente nu, possivelmente acentuando a situação de contraste criada (solo nu/vegetação adjacente); o tipo de solo, principalmente a cor, também pode ter exercido alguma influência. Por outro lado, a área III foi a que apresentou os menores níveis de coleta de cigarrinhas durante todo o estudo. Esta área se caracterizou por ser mais "fechada", com presença de árvores de grande porte ao redor e de algumas árvores e arbustos no interior da área experimental, o que possivelmente tenha dificultado a localização da mesma por D. maidis.

Outra evidência de que a migração é parte integrante do ciclo vital de $D$. maidis foi a captura de espécimes em alturas de 7, 13 e $16 \mathrm{~m}$ em Piracicaba/SP. Cigarninhas geralmente voam em velocidade máxima de $1 \mathrm{~m} / \mathrm{s}$, o que é suficiente para sua dispersão local, sendo carregadas pelo vento todas as vezes que atingem zonas onde a velocidade do vento excede a sua velocidade de vôo (Taylor, 1974). Alguns insetos utilizam os ventos como meio de transporte durante a migração, cruzando deliberadamente a interface onde sua velocidade de vôo é menor que a velocidade do vento para o início da migração, mantendo-se nesta corrente de vento por atividade continua de vôo e voando para baixo ou cessando a atividade de vôo para voltar à camada de ar onde possa voar por esforço próprio (Teraguchi, 1986). Portanto, a coleta 
de $D$. maidis em alturas superiores a $7 \mathrm{~m}$, sugere que estas cigarrinhas estavam sendo carregadas pelo vento. A sua captura foi causada provavelmente por interceptação ao acaso pelas placas adesivas amarelas, já que nesta situação as cigarrinhas não conseguem controlar a direção do vôo e a atração pela cor amarela não poderia ter sido o fator preponderante na coleta; assim, supõe-se que o número de cigarrinhas dispersas nestas correntes de vento seja elevado. A maior proporção de captura de cigarrinhas nestas alturas se deu entre os meses de dezembro e março, e os maiores picos ocorreram nos meses de março de 1998 e fevereiro de 1999 e 2000, épocas que coincidiram com o final da primeira safra do milho.

A mudança na razão sexual de captura de cigarrinhas no decorrer das diferentes épocas do ano funciona como um indicativo do status de migrante. Com relação a isso, observou-se um certo padrão para $D$. maidis em todas as áreas de Anastácio/MS. Durante a safra do milho, o número de machos coletados foi sempre maior que o de fềmeas (Figuras 8-11). Isto provavelmente se explica pelo fato de que machos de cigarrinhas apresentam uma tendência de maior movimentação entre plantas, em função de seu comportamento de côrte (Teraguchi, 1986, Hunt \& Nault, 1991), tendo então maiores probabilidades de serem atraídos e capturados pelos cartões adesivos do que as fềmeas, as quais tendem a permanecer mais tempo sobre as plantas executando atividades como a postura. Estudos sobre o comportamento de fuga de D. maidis indicaram que os machos exibem, através do vôo, maior resposta a distúrbios mecânicos do que fêmeas, possivelmente devido ao menor tamanho apresentado pelo machos (Heady \& Nault, 1985). Mesmo logo após a emergência dos adultos, quando estas diferenças de tamanho não são tão acentuadas, as fêmeas parecem ser menos móveis. No entanto, a proporção de fềmeas nas coletas aumentou nos períodos que antecederam o plantio do milho, no final da safra do milho ou nos picos populacionais por ocasião do preparo do solo (Figuras 8-11). Esta inversão na razão sexual em relação ao período da cultura do milho é congruente com a hipótese de migração. Os primeiros indivíduos que chegam na cultura (os migrantes), ou sobre o solo exposto pela aração e gradagem, seriam em sua maioria fêmeas, as principais responsáveis pela colonização inicial da cultura; por outro lado, no final da safra do milho as fêmeas estariam em maior número e 
com maior atividade para empreender o vôo migratório. Larsen et al. (1992) sugeriram que fềmeas de $D$. maidis seriam mais bem adaptadas do que machos para enfrentar a entressafra, podendo sobreviver utilizando apenas água, ao menos por um período de tempo e, se a cópula ocorre antes da entressafra, apenas fêmeas seriam necessárias para suportar este período. Estes autores registraram que 18 de um total de 25 adultos de $D$. maidis coletados no México na entressafra do milho, eram fềmeas. Da mesma forma, Flinn et al. (1990) propuseram que a diferença na razão sexual pode ser função da capacidade de sobrevivência diferenciada entre os sexos durante a migração. Fêmeas de E. fabae, entre 4,4 e $15,6^{\circ} \mathrm{C}$, podem sobreviver de $30-50 \%$ mais tempo do que machos na ausência de alimento ou água (Decker \& Cunningham, 1967). Para Taylor et al. (1993), fềmeas potencialmente emigrantes se acasalariam antes do êxodo, atrasando deste modo a emigração, aumentando a proporção de fềmeas durante este período. Nas coletas realizadas em alturas superiores a $7 \mathrm{~m}$ em Piracicaba/SP, verificou-se que $69 \%$ dos espécimes de D. maidis coletados eram fềmeas; este fato é consistente com as observações de Teraguchi (1986) de que fêmeas de muitas espécies de cigarninhas são mais capturadas por armadilhas em maiores alturas do que machos, pois estas armadilhas capturam mais migrantes do que não migrantes.

Um fato interessante é que na área VI situada em Piracicaba/SP, em quase todo o período amostrado (exceto julho 1998 e novembro a dezembro de 1999), a proporção de fềmeas coletadas foi sempre inferior à de machos, não havendo inversão na razão sexual. Heady \& Nault (1985) observaram que populações de D. maidis de áreas onde o milho é plantado continuamente demostraram significativamente menor resposta de fuga do que as de áreas onde o milho cresce estacionalmente. Estes autores sugeriram que a permanência do hábitat tem papel decisivo no grau de resposta de fuga, sendo este comportamento de vôo um possível indicativo da tendência migratória de $D$. maidis. Baseado na hipótese proposta por Heady \& Nault (1985), nós sugerimos que a não inversão na razão sexual ocorrida em Piracicaba/SP, se deveu ao fato de que nesta área o plantio contínuo do milho proporcionou a cigarrinha-do-milho um hábitat mais estável do que nas áreas situadas em Anastácio/MS, tendo as fềmeas uma menor 
resposta de fuga, ou uma menor tendência migratória, sendo assim menos capturada que os machos.

Em relação à altura de coleta, esperava-se que as coletas a 0,5 e $1,5 \mathrm{~m}$ representassem os indivíduos que estivessem desempenhando atividades terrestres (vegetativas ou triviais) como a busca de um parceiro para a cópula, ou a passagem de uma planta a outra na busca de sítios de alimentação e oviposição, e que as coletas a 2,5 $\mathrm{m}$ representassem os possíveis migrantes. No entanto, observou-se que a maioria dos indivíduos foram coletados a $0,5 \mathrm{~m}$ em todas as áreas e épocas; as exceções ocorreram a partir do meio safra do milho em que, via de regra, a coleta a $1,5 \mathrm{~m}$ superou a coleta a $0,5 \mathrm{~m}$. No início da safra do milho, enquanto as plantas estão pequenas, as cigarrinhas são mais atraídas pelos cartões situados a $0,5 \mathrm{~m}$; a medida que as plantas crescem, os vôos realizados entre uma planta e outra passam a colocar os cartões situados a $1,5 \mathrm{~m}$ dentro do campo visual de $D$. maidis e estes passam a coletar mais espécimes. A coleta a 2,5 m permaneceu em baixos níveis em todas as áreas e todas as épocas (Figuras 12-15). Desta forma, o baixo nível de coleta a $2,5 \mathrm{~m}$ contraria a hipótese migratória para $D$. maidis ? Como discutido anteriormente, o principal estímulo para os possíveis migrantes que estão em vôo parece ser o contraste entre regiões vegetadas e não vegetadas (Prokopi \& Owens, 1983), e não a direta detecção visual da planta hospedeira. Hipoteticamente, indivíduos migrantes de D. maidis executariam um vôo vertical direcionado para o solo e a partir daí, na busca da planta hospedeira, passariam a ser atraídos visualmente pela coloração amarela dos cartões adesivos, estando aqueles situados a $0,5 \mathrm{~m}$ mais próximos do campo visual destes insetos. Ao que parece, os vôos empreendidos pela cigarrinha-do-milho excedem os $7 \mathrm{~m}$, como verificado em Piracicaba/SP, e talvez a altura de $2,5 \mathrm{~m}$ não seja adequada à captura de possíveis migrantes.

Larsen et al. (1992) propuseram que D. maidis é um migrante local que voa para hábitats adjacentes aos campos de milho no final da safra, retornando a estes campos no ano seguinte, e que os adultos podem sobreviver à entressafra utilizando-se de hospedeiros alternativos ou apenas de água por um certo período. Entretanto, os resultados obtidos em Anastácio/MS sugerem que esta espécie pode utilizar-se de 
migração para localização e colonização de novos cultivos de milho em locais distantes. Durante os 29 meses em que este estudo foi desenvolvido, observou-se a captura de apenas três espécimes da cigarrinha-do-milho em vegetação adjacente às áreas I e II, nas quais o milho é plantado anualmente. Além disso, as observações visuais em hábitats contíguos as áreas experimentais, bem como a coleta com rede entomológica e succionador motorizado em gramíneas nestas mesmas áreas no período de entressafra, não permitiram observar nenhum espécime de D. maidis. Registrou-se ainda o aparecimento de D. maidis em todas as áreas de pastagem (áreas III, IV e V) onde o milho não havia sido plantado em anos anteriores, o que não seria esperado caso as populações de D. maidis fossem todas locais. A utilização de plantas hospedeiras alternativas como outras espécies de Zea L. e também de Tripsacum L., que são comuns no México e América Central (Nault, 1990; Pitre et al., 1966; Triplehom \& Nault, 1985), é uma hipótese remota já que estas não são plantas amplamente distribuídas no Brasil.

A migração é provavelmente uma característica comportamental necessária às espécies de Dalbulus que, como D. maidis, utilizam milho onde este é cultivado estacionalmente (Heady \& Nault, 1985). A instabilidade e sazonalidade do hábitat parecem condicionar este comportamento, pois espécies de cigarrinhas associadas a culturas anuais amplamente distribuídas tendem a ser mais migratórias (Teraguchi, 1986). As evidências reunidas no presente estudo permitem inferir que a migração a longas distâncias é uma possível estratégia de $D$. maidis para a sobrevivência na entressafra do milho, particularmente em regiões do Brasil onde não se cultiva o milho fora de época, na "safrinha" ou no inverno (irrigado). Estudos genéticos com algumas populações de D. maidis através de marcadores moleculares do tipo RAPD-PCR também apoiam esta hipótese (Capítulo 4).

As informações obtidas neste estudo são particularmente importantes quando se pensa no delineamento de estratégias de manejo da cigarrinha-do-milho. $\mathrm{O}$ fato de que espécimes dessa praga chegam às áreas antes do plantio da cultura e já se encontram infectivos com molicutes (Capítulo 6), e que o tipo de preparo do solo e as rebrotas têm efeito significativo na colonização inicial e manutenção de populações de cigarrinhas na 
área durante a entressafra, já indica algumas variáveis que poderiam ser manejadas visando diminuir a população inicial desse inseto vetor, que é considerado um dos principais problemas em milho na América Latina. 


\section{VARIAÇÃO GENÉTICA ENTRE E DENTRO DE ALGUMAS POPULAÇÕES DE Dalbulus maidis (DeLONG \& WOLCOTT) (HEMIPTERA: CICADELLIDAE) NO BRASIL}

RESUMO - Para cigarrinha-do-milho, Dalbulus maidis, uma das mais importantes pragas do milho (Zea mays L.) da América Latina e cuja importância no Brasil vem apresentando aumento crescente, alguns estudos têm sugerido que a migração a longas distâncias pode ser uma estratégia de sobrevivência na entressafra do milho. Estudos prévios revelaram significativas diferenças morfológicas entre populações do Nordeste e do Centro-Sul do Brasil. Nesta pesquisa, padronizou-se a metodologia RAPD-PCR para estudos com $D$. maidis e utilizou-se desta técnica para se avaliar a estrutura genética de populações desta cigarrinha de uma microregião do Brasil Central, município de Anastácio/MS, coletadas nas safras 1997/98 e 1998/99 em dois sistemas distintos: a) áreas onde se faz um único plantio anual de milho há pelo menos 5 anos e b) áreas de pastagem onde o milho não era plantado há pelo menos 5 anos; e também de cinco populações de uma macroregião, quatro municípios do Centro-Sul (Chapecó/SC, Bom Jardim da Serra/SC, Anastácio/MS e Piracicaba/SP) e um do Nordeste (Mossoró/RN) do Brasil. Foram avaliados 10 espécimes por população e 10 primers foram utilizados para a realização dos três ensaios RAPD-PCR, sendo que cada primer mostrou um padrão diferente. Para as sete populações de Anastácio/MS da safra 1997/98 foram obtidos 134 locos sendo 105 polimórficos (78,36\%); o índice de similaridade tanto dentro como entre as populações foi superior a 0,72 . Na safra 1998/99, em seis populações avaliadas, 181 locos foram registrados com 148 polimórficos $(81,77 \%)$ e índices de similaridade, inter e intrapopulacionais, superiores a 0,71 . A análise de agrupamento não permitiu a 
união dos espécimes dentro de suas populações originais, havendo uma distribuição aleatória dos mesmos, independente da safra, área ou data em que foram coletados. Para as cinco populações do Centro-Sul/Nordeste foram gerados 163 locos com 125 dos quais polimórficos $(76,69 \%)$, sendo a similaridade entre e dentro das populações superior a 0,73. Entretanto, a análise de agrupamento separou os espécimes da população do Nordeste em um grupo único, enquanto que os do Centro-Sul misturaram-se aleatoriamente. A técnica de RAPD-PCR mostrou-se bastante útil no estudo da estrutura genética de populações de $D$. maidis. Nossos resultados sugerem que o fluxo gênico entre as populações de $D$. maidis do Centro-Sul, mediado pela migração a longas distâncias, é bastante alto e que a população do Nordeste, apesar da alta similaridade com as populações do Centro-Sul, encontra-se geneticamente isolada destas populações por algum tipo de barreira geográfica ou ausência de correntes de vento, e que esta divergência genética pode ser um dos componentes da diferença morfológica observada entre populações destas duas regiões.

PALAVRAS-CHAVE: Cigarrinha-do-milho, marcador molecular, RAPD-PCR, fluxo gênico, migração.

\section{GENETIC VARIATION AMONG AND WITHIN SOME POPULATIONS OF Dalbulus maidis (DeLONG \& WOLCOTT) (HEMIPTERA: CICADELLIDAE) IN BRAZIL}

SUMMARY - For the corn leafhopper, Dalbulus maidis, one of the most important pests of maize (Zea mays L.) in Latin America and whose importance in Brazil is increasing, some studies have suggested that migration can be a survival strategy in the corn overseason. Previous studies revealed significant morphologic differences among populations of the Northeast and of the Center-South of Brazil. In this research, RAPDPCR was used to evaluate the genetic structure of $D$. maidis populations of a microregion of Central Brazil, in Anastácio locality of, State of Mato Grosso do Sul 
populations were sampled in crop seasons of 1997/98 and 1998/99, in two different systems: a) areas where a single annual planting of maize had been done in the same plot in the previous 5 years and $b$ ) isolated pasture areas where maize had not been planted in the previous 5 years. Five populations of a macroregion, collected from different localities in the Center-South (Chapecó/SC, Bom Jardim da Serra/SC, Anastácio/MS and Piracicaba/SP) and Northeast (Mossoró/RN) of Brazil. were also compared ten specimens were evaluated for population and 10 primers were used for the accomplishment of three RAPD-PCR assays, where each primer showed a different pattern. In the crop season of 1997/98, 134 loci were obtained for the seven populations of Anastácio/MS 105 (78.4\%) were polymorphic; the similarity index within as well among the populations was $>0.72$. In 1998/99, 181 loci were registered in six evaluated populations, and $148(81.8 \%)$ were polymorphic; similarity indexes, within and among populations, were $>0.71$. The grouping analysis did not allow the union of the specimens within their original populations; specimens from different populations were all mixed and no pattern related to crop season, collection dates or location was detected. For the five populations of the macroregion, 163 loci were generated and $125(76.7 \%)$ were polymorphic; the similarity among and within populations was $>0.73$. However, the grouping analysis separated the specimens of the population from the Northeast in a single group, while the ones of the Center-South region were mixed randomly. The technique of RAPD-PCR was shown to be quite useful in the study of genetic structure of $D$. maidis populations. Our results suggest that the gene flow among the populations of $D$. maidis of the Center-South, mediated by the migration at long distances, is rater high. The population of the Northeast, in spite of its high similarity with the populations of the Center-South, appears to be genetically isolated by some type of geographical barrier or absence of wind currents. This genetic divergence might be one of the factors underlying the morphologic difference reported for populations of these two regions in a previous study.

KEY WORDS: Corn leafhopper, molecular marker, RAPD-PCR, gene flow, migration. 


\subsection{INTRODUÇĀO}

O fenômeno de variação morfológica entre populações de uma mesma espécie de regiões geograficamente distintas tem sido documentado para muitos insetos (McNab, 1971; Murphy, 1985; Oliveira, 1996). Estudos de laboratório têm demonstrado que fatores como temperatura, comprimento do dia e idade da planta hospedeira concorrem para diferenças no tamanho, peso e pigmentação de adultos de cigarrinhas, como demostrado para Empoasca fabae (Harris) (Simonet \& Pienkowski, 1980) e Graminella nigrifrons (Forbes) (Larsen et al., 1990). Estes fatores podem variar muito de uma região geográfica para outra, podendo contribuir significativamente para diferenças morfológicas observadas entre populações. Entretanto, o componente genético também pode estar atuando nestas diferenças morfológicas. Neste contexto, torna-se importante analisar as estratégias usadas pelos insetos para enfrentar uma condição adversa como a ausência da planta hospedeira. A utilização de plantas hospedeiras alternativas, a permanência em restos culturais e a dormência, têm sido apontadas como possíveis estratégias para cigarrinhas e outros insetos (Bames, 1954; Delinger, 1986; DeLong \& Caldwell, 1935). A migração a longas distâncias é uma outra alternativa que tem sido observada em algumas espécies de cigarrinhas como E. fabae (Harris) (Carlson et al., 1992), Nilaparvata lugens Stål (Holt et al., 1996) Sogatella furcifera Horváth (Kisimoto \& Sogawa, 1995) e Macrosteles quadrilineatus Forbes (Hoy et al., 1992). A migração parece ser especialmente importante para cigarrinhas que utilizam hospedeiros anuais e que são monófagas ou oligófagas (Heady \& Nault, 1985; Teraguchi, 1986). Portanto, variações morfológicas entre populações podem ter um componente genético e estratégias como a migração podem ter um impacto significativo neste componente genético, dentro destas populações.

Dalbulus maidis (DeLong \& Wolcott) é uma espécie amplamente distribuída pelas Américas, alimentando-se principalmente de milho (Zea mays L.) (Nault, 1990). Por ser vetora de importantes patógenos da cultura, tem sido considerada como a mais importante praga do milho na América Latina (Nault, 1980; 1990). Em estudos com 
diversas populações de D. maidis no Brasil, Oliveira (1996) observou diferenças morfológicas significativas entre populações coletadas no Nordeste e Centro-Sul, sendo as populações do Nordeste menores, menos pesadas e com menor pigmentação do exoesqueleto. Diferenças morfológicas em laboratório para esta espécie também foram registradas por Larsen et al. (1994). Pouco se sabe a respeito das estratégias de sobrevivência desta cigarrinha na entressafra do milho no México ou no Brasil, mas existem evidências de que ocorre migração a longas distâncias (Taylor et al., 1993; Capítulo 3).

A biologia molecular tem se expandido grandemente nos últimos anos e para a entomologia, assim como para outras áreas biológicas, tem proporcionado um novo nível de resolução para estudos envolvendo diversas áreas do conhecimento (Loxdale \& Lushai, 1998). Para o estudo genético de populações existe hoje uma poderosa ferramenta, a técnica de DNA polimórfico amplificado ao acaso ("Random Amplified Polymorphic DNA" - RAPD ou "Arbitrarily primed PCR" - AP-PCR) (Welsh \& McClelland, 1990; Willians et al., 1990) que utiliza um único primer curto $(\approx 10$ nucleotídeos), que anela-se em regiões arbitrárias do genoma e sintetiza múltiplos produtos de amplificação através da reação da polimerase em cadeia ("Polimerase Chain Reaction" - PCR) (Saiki et al., 1988). O método permite a deteç̧ão de um grande número de polimorfismos de DNA, na ausência de informação específica da seqüência de nucleotídeos do DNA molde (Willians et al., 1990). RAPD-PCR é uma técnica simples, que requer pequenas quantidades de material biológico (Chan et al., 1999), o que é uma grande vantagem quando se trabalha com organismos pequenos, como são muitos insetos (Loxdale et al., 1996). Esta técnica tem sido amplamente empregada em entomologia em estudos de populações (Black et al., 1992; Cenis et al., 1993; Guirao et al., 1997; Infante-Malachias et al., 1999; Lin et al., 1999; Puterka et al., 1993; Skinner \& Camacho, 1995). Para D. maidis, estudos anteriores com marcadores moleculares visaram principalmente a busca de informações a respeito da filogenia do gênero, como nos trabalhos com isoenzimas (Triplehorn et al., 1990) e DNA mitocondrial (Dietrich et al., 1998). 
Neste trabalho padronizou-se a metodologia de RAPD-PCR para estudos com D. maidis e utilizou-se a técnica para avaliar a estrutura genética de populações dessa cigarrinha de uma microregião do Brasil Central e também de cinco municípios de uma macroregião (Centro-Sul e Nordeste), visando-se obter informações do nível de fluxo gênico entre populações e subsídios para embasamento de estudos de migração (Capítulo 3) e variação morfológica (Oliveira, 1996) dessa espécie.

\subsection{MATERIAL E MÉTODOS}

\subsection{1. Áreas em estudo}

O estudo em nível de microregião foi realizado no município de Anastácio/MS em cinco locais com as seguintes características: a) áreas I e II: propriedades rurais de $\approx 20$ ha, com cerca de 3-4 ha dedicados ao plantio do milho em única safra anual há pelo menos 5 anos; b) áreas III, IV e V: propriedades rurais com áreas de $\approx 70$ ha ocupados por pastagem (braquiária), sem plantio de milho há mais de 5 anos. O milho foi plantado nestas áreas nos anos de 1997/98 e 1998/99 (Tabela 2, Figura 24). No estudo macroregional, cinco municípios de quatro regiões do Brasil foram envolvidos: Chapecó/SC e Bom Jardim da Serra/SC da região Sul, Anastácio/MS da região Centro-Oeste, Piracicaba/SP da região Sudeste e Mossoró/RN da região Nordeste (Tabela 2, Figura 24). 
Tabela 2. Locais e datas de amostragem de populações de Dalbulus maidis em milho em cinco municípios Brasileiros e em Anastácio/MS nas safras 1997/98 e 1998/99.

\begin{tabular}{|c|c|c|c|c|c|c|c|c|}
\hline \multicolumn{5}{|c|}{ Brasil } & \multicolumn{4}{|c|}{ Anastácio/MS } \\
\hline \multirow[t]{2}{*}{ Municípios } & \multirow[b]{2}{*}{ Lat. (S) } & \multirow[b]{2}{*}{ Lon. (W) } & \multirow[b]{2}{*}{ Alt. (m) } & \multirow[b]{2}{*}{ Data } & \multicolumn{2}{|c|}{ Safra $1997 / 98$} & \multicolumn{2}{|c|}{ Safra 1998/99 } \\
\hline & & & & & Área ${ }^{1,2}$ & Data & Área $^{1,2}$ & Data \\
\hline Chapecó/SC & $27^{\circ} 05^{\prime} 47^{\prime \prime}$ & $52^{\circ} 37^{\prime} 06^{\prime \prime}$ & 674 & $17 / 03 / 98$ & IA & $15 / 12 / 97$ & IA & $09 / 12 / 98$ \\
\hline Bom J. Serra, SC & $28^{\circ} 20^{\prime} 13^{\prime \prime}$ & $49^{\circ} 37^{\prime} 29^{\prime \prime}$ & 1.245 & $04 / 01 / 99$ & IB & $20 / 05 / 98$ & IB & 08/02/99 \\
\hline Anastácio/MS & $20^{\circ} 29^{\prime} 01^{\prime \prime}$ & $55^{\circ} 48^{\prime} 25^{\prime \prime}$ & 160 & $09 / 12 / 98$ & IIA & $15 / 12 / 97$ & IIB & $08 / 02 / 99$ \\
\hline Piracicaba/SP & $22^{\circ} 43^{\prime} 31^{\prime \prime}$ & $47^{\circ} 38^{\prime} 57^{\prime \prime}$ & 547 & $22 / 03 / 99$ & IIB & $07 / 03 / 98$ & IVA & $09 / 12 / 98$ \\
\hline \multirow[t]{3}{*}{ Mossoró/RN } & $05^{\circ} 11^{\prime} 15^{\prime \prime}$ & $37^{\circ} 20^{\prime} 39^{\prime \prime}$ & 16 & $11 / 06 / 99$ & IIIA & $15 / 01 / 98$ & IVB & 08/02/99 \\
\hline & & & & & IVA & $15 / 01 / 98$ & VB & $09 / 12 / 98$ \\
\hline & & & & & IVB & $20 / 05 / 98$ & & \\
\hline
\end{tabular}

Áreas I e II - plantio do milho em única safra anual há pelo menos 5 anos; áreas III, IV e V - áreas de pastagem sem plantio de milho há mais de 5 anos, nas quais o milho foi plantado nos anos de 1997/98 e 1998/99;

${ }^{2}$ As letras ao lado da identificação das áreas indicam A - ínicio da safra do milho e Bmeio ou final da safra.

\subsubsection{Obtenção de cigarrin has}

No município de Anastácio/MS, sete populações de D. maidis foram amostradas na safra do milho de $1997 / 98$ nas áreas I, II, III e IV e seis na safra 1998/99 nas áreas I, II, IV e V, em duas fases distintas da cultura: início da safra e meio ou final da safra (Tabela 2). Para os municípios de Chapecó/SC, Bom Jardim da Serra/SC, Anastácio/MS, Piracicaba/SP e Mossoró/RN apenas uma amostragem foi realizada durante a safra, totalizando cinco populações. As cigarrinhas foram coletadas com 


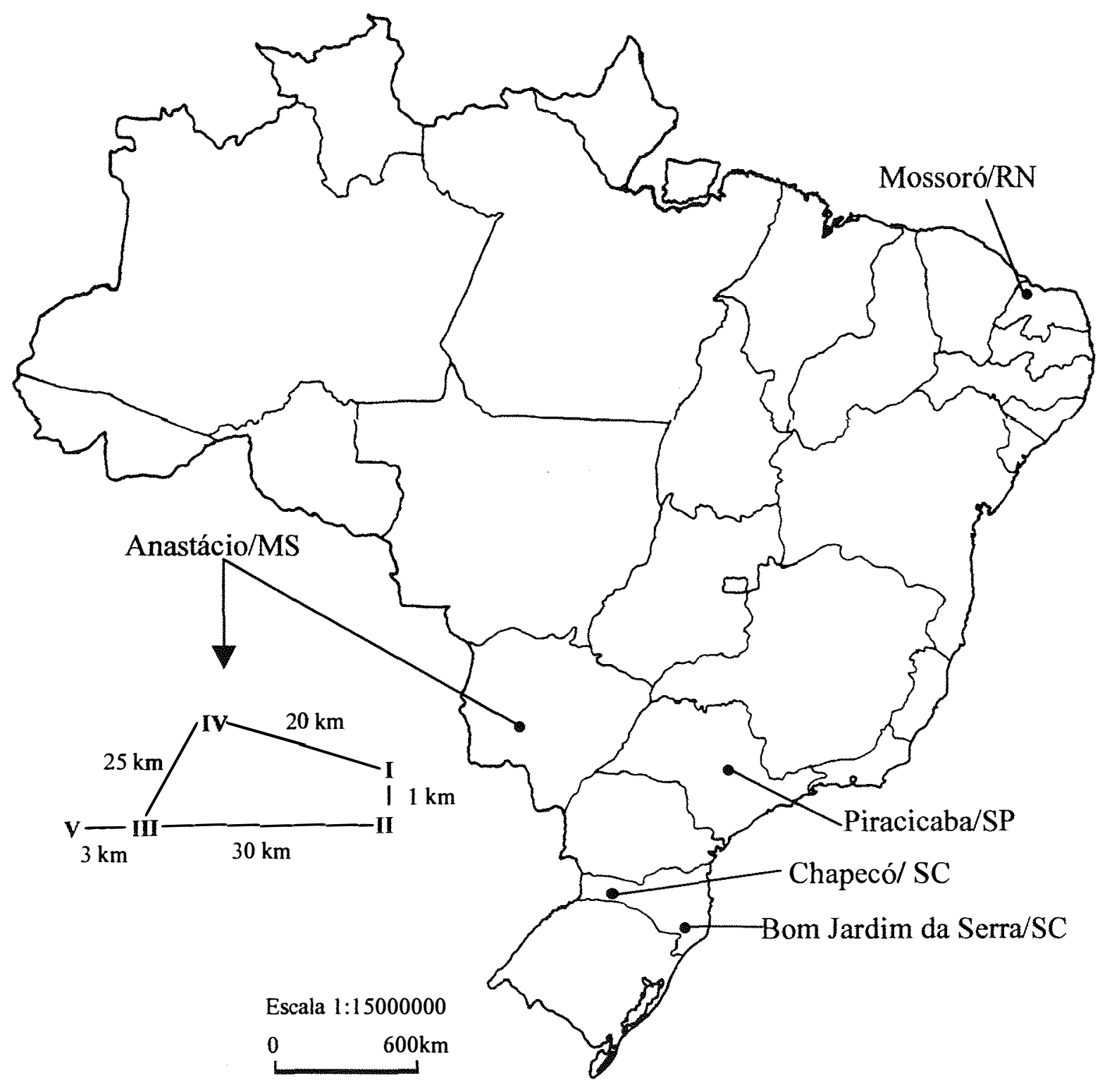

Figura 24. Localização geográfica dos municípios de coleta de populações de Dalbulus maidis no Brasil e das áreas localizadas em Anastácio/MS, com a distância aproximada entre as mesmas. 
aspirador bucal diretamente do cartucho das plantas de milho e transportadas vivas ao laboratório, onde foram mortas e mantidas a $-20^{\circ} \mathrm{C}$ até o momento da extração do DNA. Uma exceção foi a população de Mossoró/RN, cujos espécimes foram mantidos em álcool 70\% no transporte ao laboratório e, após uma pré-lavagem em água destilada por 5 min e em TE (10 mM de Tris e $1 \mathrm{~m} \mathrm{M}$ de EDTA; pH 8,0) por 1,5 h sob agitação, também foram armazenados a $-20^{\circ} \mathrm{C}$. Para os ensaios foram tomados, aleatoriamente e sem sexagem, 10 espécimes de $D$. maidis por população.

\subsubsection{Extração do DNA}

Três ensaios foram realizados separadamente, o primeiro com as sete populações coletadas na safra $1997 / 98$ em Anastácio/MS, o segundo com as seis populações da safra 1998/99 de Anastácio/MS e o terceiro com as cinco populações coletadas nas quatro regiões brasileiras (Chapecó/SC, Bom Jardim da Serra/SC, Anastácio/MS, Piracicaba/SP e Mossoró/RN). Em cada um dos ensaios, 10 espécimes de cada população foram submetidos individualmente à extração do DNA genômico total, seguindo-se o protocolo modificado de Raeder \& Broda (1985). Os espécimes foram colocados em tubos de microcentrífuga $(1,5 \mathrm{ml})$, macerados em presença de $300 \mu \mathrm{l}$ de tampão de extração e incubados a $65^{\circ} \mathrm{C}$ por $30 \mathrm{~min}$. Em seguida, foram feitas três extrações orgânicas com: fenol, fenol:clorofórmio:álcool isoamílico (25:24:1) e clorofórmio:álcool isoamílico (24:1). Nas três extrações, acrescentou-se $300 \mu \mathrm{l}$ de cada solvente, centrifugou-se a 14.800 g por $10 \mathrm{~min}$ e recolheu-se o sobrenadante. O DNA foi precipitado da fase aquosa, ao final da extração, pela adição de igual volume de álcool isopropilico e de $\mathrm{NaCl}$ para uma concentração final de 0,3 $\mathrm{M}$. As amostras foram mantidas em freezer $\left(-20^{\circ} \mathrm{C}\right)$ por no mínimo $12 \mathrm{~h}$. A sedimentação foi feita por centrifugação a $14.800 \mathrm{~g}$ por $10 \mathrm{~min}$. O DNA foi lavado com álcool etílico $70 \%$, seco ao ar, ressuspendido em $20 \mu \mathrm{l}$ de TE e armazenado em freezer $\left(-20^{\circ} \mathrm{C}\right)$ até a quantificação. 
O DNA total de cada espécime foi quantificado pela fluorescência de uma alíquota de $2 \mu \mathrm{l}$ de DNA extraído após mistura com o pigmento Hoescht 33258 Dye (Cesarone et al., 1979), utilizando-se fluorímetro Versa Fluor (Bio-Rad Laboratories, Hercules, CA 94547, USA) ou pela comparação com lambda DNA (20 ng/ $\mu$ l) (Gibco BRL) em gel de agarose $0,8 \%$ (Sambrook et al., 1989).

\subsubsection{Otimização das condições de amplificação}

Visando determinar a condição ótima para amplificação do DNA de D. maidis via RAPD-PCR, foram realizados testes com os seguintes componentes da reação: a) quantidade de DNA molde, variando de 3 a $21 \mathrm{ng}$ com incremento de $3 \mathrm{ng}$; b) concentração de cloreto de magnésio $\left(\mathrm{MgCl}_{2}\right)$, variando de 0,5 a $5 \mathrm{mM}$ com incremento de $0,5 \mathrm{mM}$; c) nucleotídeos (dNTP's) (Pharmacia), variando de 100 a 400 $\mu \mathrm{M}$ com incremento de $50 \mu \mathrm{M}$; d) primer, variando de 0,10 a $0,40 \mu \mathrm{M}$ com incremento

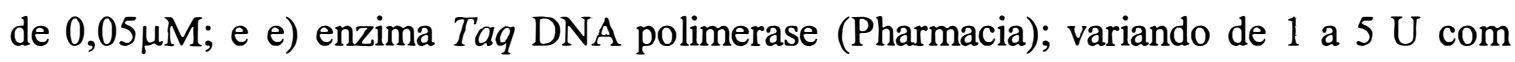
incremento de $1 \mathrm{U}$. Os valores acima referem-se a concentração final de cada reagente para uma reação RAPD-PCR.

\subsubsection{Amplificação via RAPD-PCR}

A amplificação foi realizada em um volume final de $20 \mu \mathrm{l}$ contendo $6 \mathrm{ng}$ de DNA; 4 mM de $\mathrm{MgCl}_{2} ; 0,25 \mathrm{mM}$ de dNTP; 0,3 $\mu \mathrm{M}$ do primer e 1 unidade de Taq DNA polimerase, adicionando-se ao final $30 \mu \mathrm{l}$ de óleo mineral. Como controle negativo foi utilizada uma amostra que continha todos os reagentes, exceto DNA de cigarrinha. As reações foram realizadas em termociclador PTC-100 (MJ Research, Inc., Watertown, 
MA 02172, USA) nas seguintes condições de amplificação: $92^{\circ} \mathrm{C}$ por $5 \min (1 \mathrm{ciclo}$ ), $92^{\circ} \mathrm{C}$ por $40 \mathrm{~s}, 40^{\circ} \mathrm{C}$ por $1,5 \min$ e $72^{\circ} \mathrm{C}$ por $2 \min \left(40\right.$ ciclos) e $72^{\circ} \mathrm{C}$ por $5 \min (1$ ciclo). Vinte e quatro primers foram testados inicialmente para a seleção daqueles que proporcionassem amplificações mais robustas e reproduzíveis; 10 primers selecionados foram utilizados para o estudo com D. maidis nos três ensaios (Tabela 3).

Tabela 3. Seqüência de bases de todos os primers testados e daqueles que foram efetivamente utilizados nos estudos com populações de Dalbulus maidis.

\begin{tabular}{|c|c|c|c|c|c|}
\hline Primer $^{1}$ & Seqüência & No bases & Primer $^{2}$ & Seqüência & $\begin{array}{c}\mathrm{N}^{\mathbf{0}} \\
\text { bases }\end{array}$ \\
\hline OPA- $01^{*}$ & 5'-AGACGGCTCC-3' & 10 & CK-06 & 5'-GCTTCGATACG-3' & 11 \\
\hline OPA- $04 *$ & 5'-AATCGGGCTG-3' & 10 & CK-09 & 5'-TCACGATGCA-3' & 10 \\
\hline OPA-07* & 5'-GAAACGGGTG-3' & 10 & CK-12 & 5'-CGACGTTCAA-3' & 10 \\
\hline OPA-11* & 5'-CAATCGCCGT-3' & 10 & CK-16 & 5'-ATCGATCGAG-3' & 10 \\
\hline OPA-16* & 5'-AGCCAGCGAA-3' & 10 & F-06 & 5'-GGGAATTCGG-3' & 10 \\
\hline OPA-18* & 5'-AGGTGACCGT-3' & 10 & F-07 & 5'-CCGATATCCC-3' & 10 \\
\hline OPC-02* & 5'-GTGAGGCGTC-3' & 10 & $F-08$ & 5'-GGGATATCGG-3' & 10 \\
\hline OPC-05* & 5'-GATGACCGCC-3' & 10 & $F-10$ & 5'-GGAAGCTTGG-3' & 10 \\
\hline OPE-11* & 5'-GAGTCTCAGG-3' & 10 & $\mathrm{H}-01$ & 5'-GGTCGGAGAA-3' & 10 \\
\hline OPE-14* & 5'-TGCGGCTGAG-3' & 10 & $\mathrm{H}-02$ & 5'-TCGGACGTGA-3' & 10 \\
\hline OPC-01 & 5'-TTCGAGCCAG-3' & 10 & & & \\
\hline OPC-04 & 5'-CCGCATCTAC-3' & 10 & & & \\
\hline OPC-06 & 5'-GAACGGACTC-3' & 10 & & & \\
\hline OPC-18 & 5'-TGAGTGGGTG-3' & 10 & & & \\
\hline
\end{tabular}

* Pimers selecionados para os estudos com a cigarinha-do-milho;

${ }^{1}$ Primers sintetizados pela Gibco BRL do Brasil;

${ }^{2}$ Primers sintetizados pela MWG-Biotech (Miami FL, EUA);

Após a adição de $3 \mu \mathrm{l}$ do tampão de corrida, $20 \mu$ das amostras amplificadas foram aplicados em gel de agarose $1,4 \%$ e submetidas à eletroforese em tampão TBE (100 mM Tris, $83 \mathrm{mM} \mathrm{H}_{3} \mathrm{Bo}_{3}$ e $1 \mathrm{mM}$ EDTA). A eletroforese foi conduzida a 3,5 V/cm por 3,5 h. O gel foi corado em solução de brometo de etídio $(1 \mu \mathrm{g} / \mathrm{ml}$ de solução) por aproximadamente $1 \mathrm{~h}$, fotografado sob luz U.V.com filme branco e preto NeoPan ASA 100 (Fuji Photo Film da Amazônia Ltda, Manaus, AM 69075-000, Brasil), sendo a foto 
revelada e ampliada em papel Kodabrome II RC (Kodak da Amazônia Ind. Com. Ltda, Manaus, AM 69075-000, Brasil). Realizou-se também captura pelo sistema de documentação de gel "Eagle Eye II" (Stratagene, La Jolla, CA 92037, USA), para a estimativa dos pesos moleculares dos locos amplificados. Para se evitar problemas relacionados com a variação no número e intensidade dos produtos de amplificação, a comparação entre a mobilidade das bandas foi feita somente dentro de um mesmo gel e baseados em uma mesma reação de RAPD-PCR.

\subsubsection{Análise dos dados}

Baseando-se nas fotografias dos géis, apenas as bandas mais visíveis e reproduzíveis foram usadas como marcadores (Roderick, 1996), sendo que bandas com mobilidade similar àquelas detectadas no controle negativo não foram registradas (Thormann et al., 1994). Em cada um dos três ensaios foi gerada uma matriz binária (1, presença de banda e 0, ausência de banda) (Apêndices 3, 4 e 5) e, utilizando-se o programa NTSYS-pc versão 1.7 (Exeter Software, Setauket, New York) (Rolf, 1992), foram construídas matrizes de similaridade utilizando-se o índice de Jaccard (J) (Sneath \& Sokal, 1973). Este índice não considera a ausência simultânea de marcador em dois indivíduos como medida de similaridade e é dado pela fórmula $J=A /(N-D)$, onde $A$ representa o número de presenças simultâneas dos marcadores em dois indivíduos, $\mathrm{N}$ significa o total de presença ou ausência de marcadores e $\mathrm{D}$, o número de ausências simultâneas dos marcadores em dois indivíduos. Baseado nestas matrizes foi feita uma análise de agrupamento via UPGMA ("unweighted pair group method of arithmetic means") utilizando-se o NTSYS-pc versão 1.7. 


\subsection{RESULTADOS}

Amplificações bastante visíveis e robustas foram conseguidas com todas as concentrações de DNA de D. maidis testadas, entre 3 e $21 \mathrm{ng}$. Estabeleceu-se nesse estudo uma quantidade de 6 ng por reação como padrão para a execução de todos os ensaios. Amplificações marginais foram obtidas com concentrações de $\mathrm{MgCl}_{2}$ inferiores a $3 \mathrm{mM}$ e o melhor padrão de amplificação foi com $4 \mathrm{mM}$. Com relação às dNTPs, a melhor concentração foi de $250 \mu \mathrm{M}$; acima deste valor o número de bandas foi reduzido, não havendo amplificação com $400 \mu \mathrm{M}$. Para o primer, concentrações acima de $0,30 \mu \mathrm{M}$ mostraram-se satisfatórias. Com relação a enzima Taq DNA polimerase as amplificações foram adequadas para todas as concentrações testadas, tendo sido selecionada a concentração de $1 \mathrm{U}$.

Todos os 24 primers testados mostraram-se capazes de amplificação do DNA de $D$. maidis e destes, 10 primers foram selecionados para o estudo das populações por apresentarem um grande número de produtos de amplificação distinguíveis $\mathrm{e}$ reproduzíveis (Tabela 3), sendo que cada um dos primers produziu um único perfil RAPD-PCR. Um mesmo DNA foi amplificado em diferentes reações RAPD-PCR com os 10 primers selecionados e a reproducibilidade foi alta, não havendo grandes diferenças nos perfis gerados, exceto por algumas bandas de alto peso molecular que variaram de uma reação a outra; porém, estas não foram consideradas neste estudo. Muitos locos gênicos foram amplificados de forma consistente, com pesos moleculares estimados entre 200 e 2.600 pares de bases (Figuras 25-27). Locos população-específico não foram encontrados para nenhuma das populações de $D$. maidis estudadas, e em nenhuma das populações foram encontradas duas cigarrinhas com genótipo idêntico. 

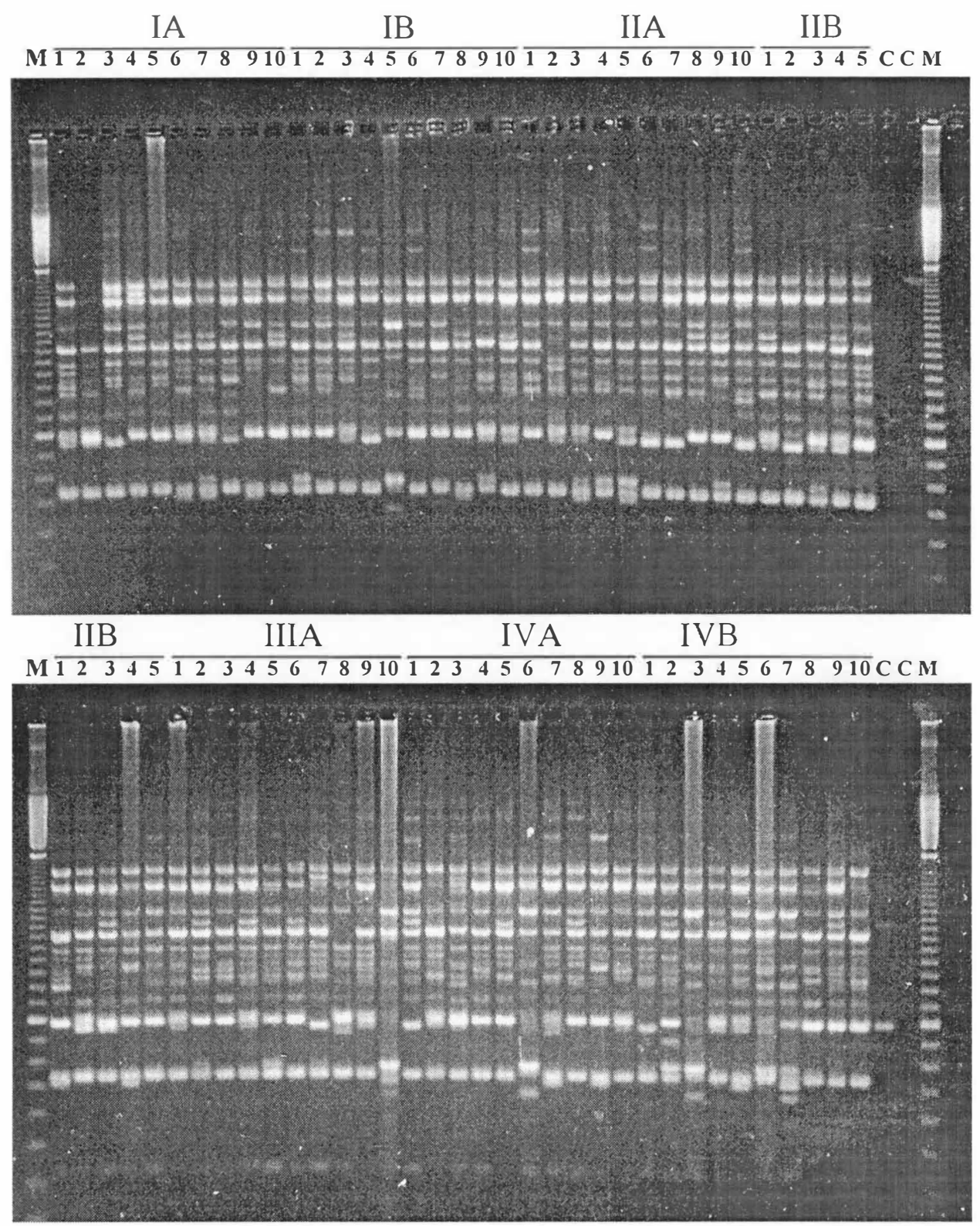

Figura 25. Produtos da amplificação de DNA de Dalbulus maidis via RAPD-PCR pelo primer OPA-07, em gel de agarose 1,4\%. Dez espécimes avaliados de cada uma das 7 populações amostradas no município de Anastácio/MS (áreas IA, IB, IIA, IIB, IIIA, IVA e IVB), na safra 1997/98. M - marcador (100 base-pair Ladder) (Pharmacia) e C - controle negativo (todos os componentes da reação menos o DNA). 

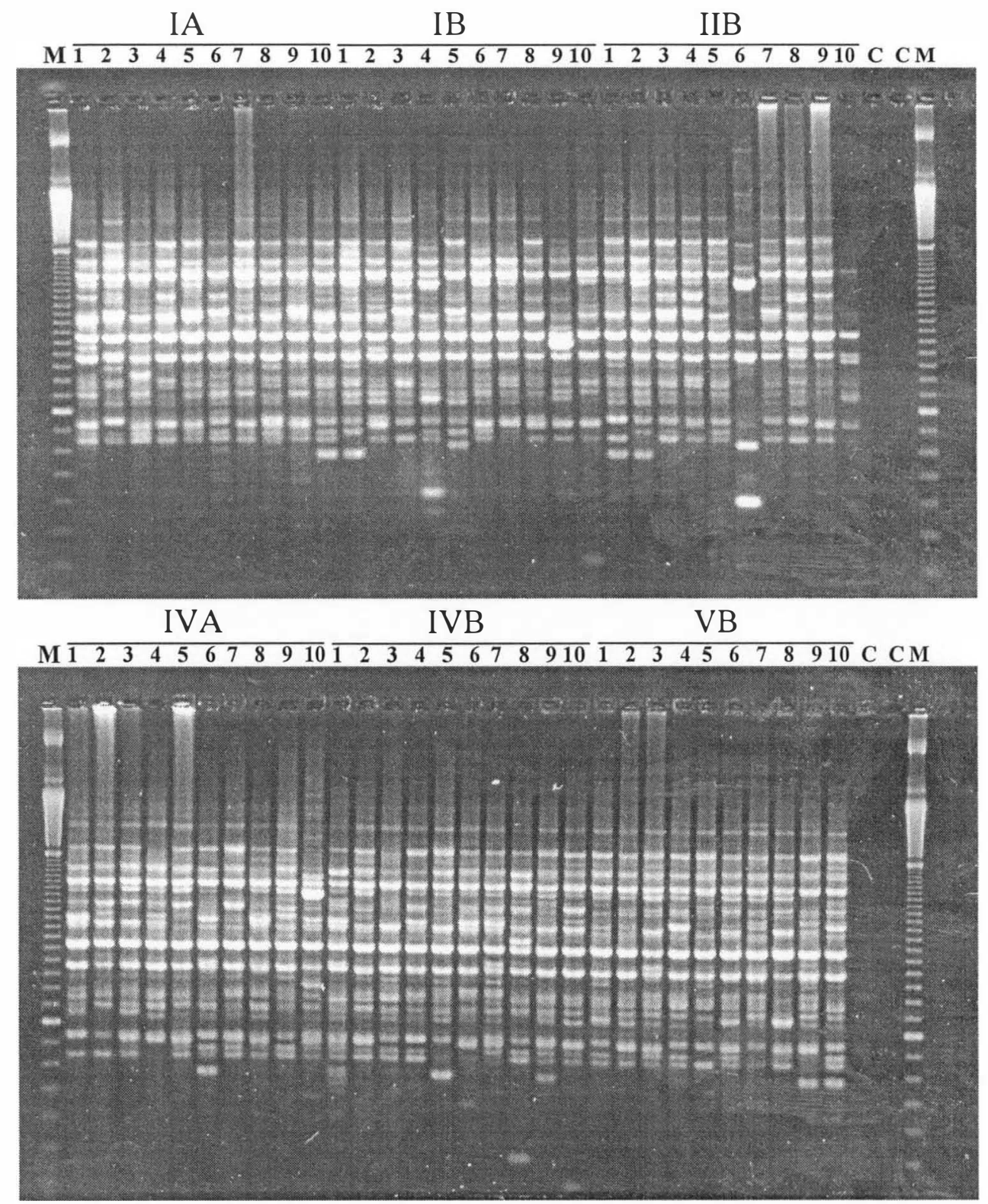

Figura 26. Produtos da amplificação de DNA de Dalbulus maidis via RAPD-PCR pelo primer OPE-14, em gel de agarose 1,4\%. Dez espécimes avaliados de cada uma das 6 populações amostradas no município de Anastácio/MS (áreas IA, IB, IIB, IVA, IVB e VB), na safra 1998/99. M - marcador (100 base-pair Ladder) (Pharmacia) e $\mathrm{C}$ - controle negativo (todos os componentes da reação menos o DNA). 
Chapecó,SC Bom J. Serra, SC Anastácio, MS

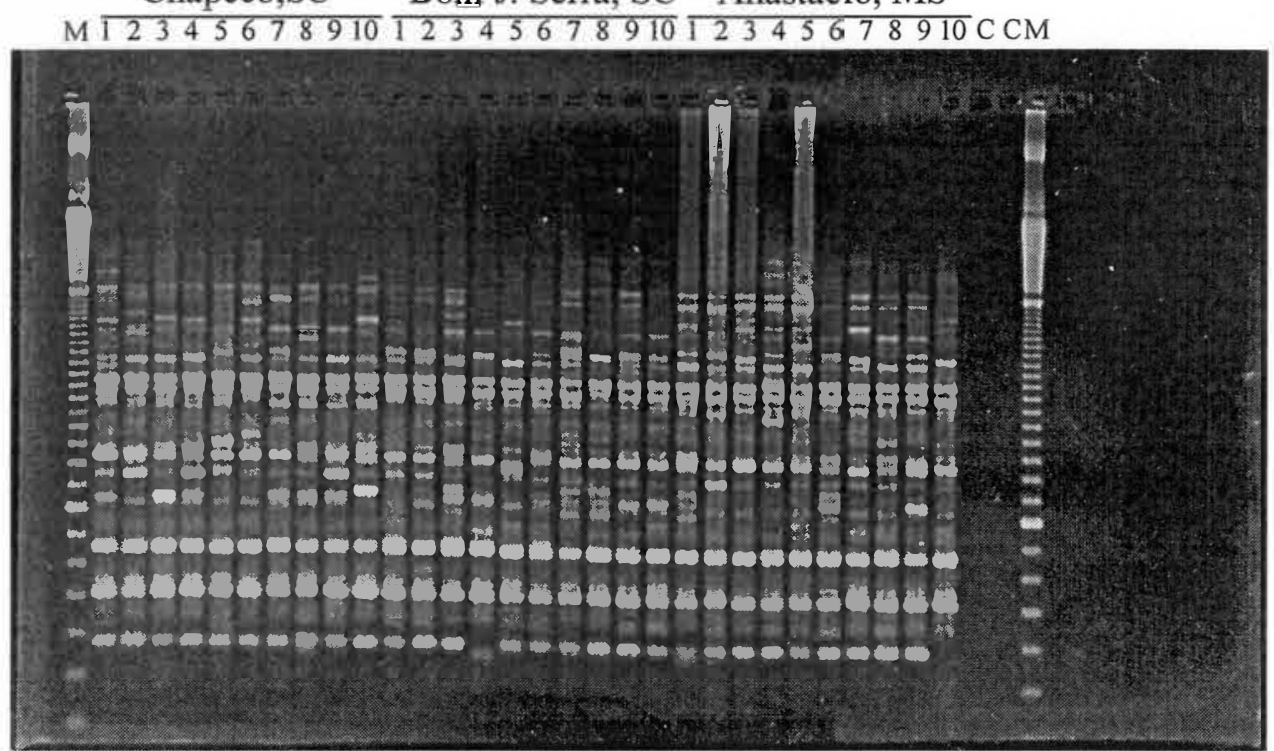

Piracicaba,SP Mossoró, $\mathrm{RN}$

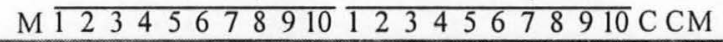

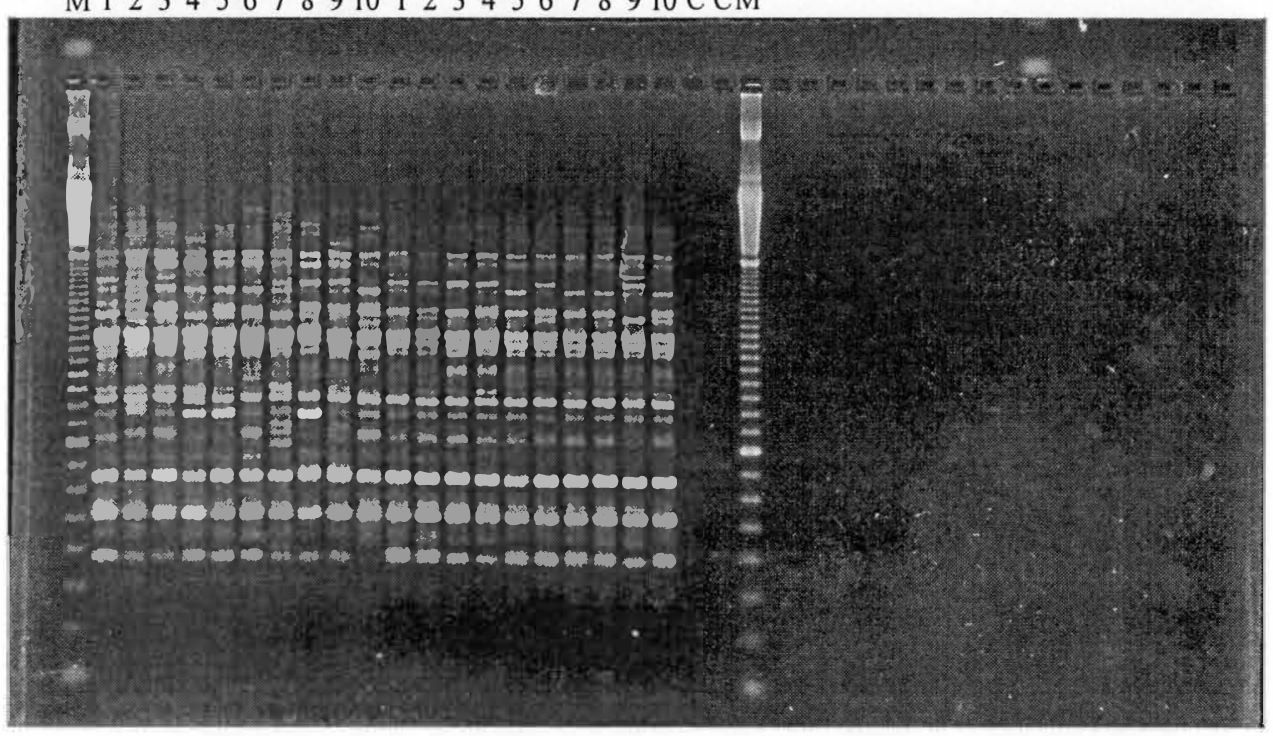

Figura 27. Produtos da amplificação de DNA de Dalbulus maidis via RAPD-PCR pelo primer OPC-05, em gel de agarose 1,4\%. Dez espécimes avaliados de cada uma das 5 populações amostradas nos municípios de Chapecó/SC, Bom Jardim da Serra/SC, Anastácio/MS, Piracicaba/SP e Mossoró/RN. M marcador (100 base-pair Ladder) (Pharmacia) e C - controle negativo (todos os componentes da reação menos o DNA). 
Os 10 primers utilizados geraram 134 locos para as populações coletadas em Anastácio/MS na safra 1997/98, dos quais 105 foram polimórficos (78,36\%). O índice de similaridade entre os espécimes destas populações variou de 0,606 (entre os espécimes IIA-5 e IIA-9) a 0,918 (entre os espécimes IIB-1 e IIB-2), sendo a média de 0,769. A similaridade média dentro de cada população variou de 0,723 (IIA) a 0,802 (IVB) (Tabela 4) e a similaridade interpopulacional variou de 0,743 (IIA x IIIA) a 0,787 (IB x IVB) (Tabela 5). Na safra 1998/99, 181 locos foram registrados e $148(81,77 \%)$ foram polimórficos; a similaridade entre os espécimes destas populações foi de 0,525 (entre os espécimes VB-6 e VB-7) a 0,881 (entre os espécimes IB-4 e IIB-2) com uma média de 0,737, a similaridade média intrapopulacional variou de 0,719 (VB) a 0,795 (IIB) (Tabela 4) e a similaridade entre as populações foi de 0,714 (IB x VB) a 0,765 (IIB x IVA) (Tabela 5). Finalmente, para as cinco populações coletadas em diferentes regiões do Brasil registraram-se 163 locos, sendo 125 polimórficos (76,69\%). Entre os espécimes das populações o índice de similaridade variou de 0,616 (entre os espécimes Anastácio-6 e Piracicaba-10) a 0,894 (entre os espécimes Mossoró-2 e Mossoró-6); dentro das populações foram observadas similaridades entre 0,750 (Anastácio/MS) e 0,807 (Mossoró, RN) (Tabela 4), e entre as populações este índice variou de 0,735 (Anastácio/MS x Mossoró/RN) a 0,763 (Chapecó/SC x Bom Jardim da Serra/SC) (Tabela 5).

Para as populações coletadas em Anastácio nas safras 1997/98 e 1998/99, a análise de agrupamento não permitiu a união dos espécimes em suas populações originais (Figuras 28 e 29). Observou-se uma distribuição aleatória dos espécimes em agrupamentos que não tiveram relação com a área ou data de coleta das populações. Quando estas áreas foram agrupadas entre si (Figura 31A e B), a união também foi aleatória, não havendo agrupamento nem mesmo de populações coletadas na mesma área e safra em datas diferentes. Para as populações coletadas em diversas regiões do Brasil, a análise de agrupamento reuniu claramente os espécimes coletados em Mossoró/RN em um único grupo (Figura 30), enquanto que nas outras populações os espécimes formaram grupos aleatórios contendo espécimes das várias localidades de coleta. Quando o agrupamento foi feito em relação à população como um todo (Figura 
31C), as localidades do Sul (Chapecó/SC e Bom Jardim da Serra/SC) formaram um primeiro grupo, seguido por Piracicaba/SP, Anastácio/MS, e por último, a população de Mossoró/RN.

Tabela 4. Valores médios do índice de similaridade de Jaccard (J), baseado em marcadores RAPD-PCR, pela comparação dos padrões RAPD-PCR dos indivíduos, dentro de cada população de Dalbulus maidis amostrada em diferentes municípios Brasileiros e na região de Anastácio/MS.

\begin{tabular}{lccccc}
\hline \multirow{2}{*}{ Brasil } & & \multicolumn{5}{c}{ Anastácio/MS } \\
\cline { 2 - 6 } \multicolumn{1}{c}{ Municípios } & J & Área $^{1,2}$ & J & Área ${ }^{1,2}$ & J \\
\hline Chapecó/SC & 0,769 & IA & 0,771 & IA & 0,730 \\
Bom J. Serra, SC & 0,779 & IB & 0,780 & IB & 0,723 \\
Anastácio/MS & 0,750 & IIA & 0,723 & IIB & 0,795 \\
Piracicaba/SP & 0,769 & IIB & 0,776 & IVA & 0,756 \\
Mossoró/RN & 0,807 & IIIA & 0,769 & IVB & 0,726 \\
& & IVA & 0,777 & VB & 0,719 \\
& & IVB & 0,802 & & \\
\hline
\end{tabular}

7 Áreas I e II - plantio do milho em única safra anual há pelo menos 5 anos; áreas III, IV e V - áreas de pastagem sem plantio de milho há mais de 5 anos, nas quais o milho foi plantado nos anos de 1997/98 e 1998/99;

${ }^{2}$ As letras ao lado da identificação das áreas indicam A - ínicio da safra do milho e Bmeio ou final da safra. 
Tabela 5. Valores médios do índice de similaridade de Jaccard (J), baseado em marcadores RAPD-PCR, pela comparação dos padrões RAPD-PCR dos indivíduos, entre as populações de Dalbulus maidis amostrada em diferentes municípios Brasileiros e na região de Anastácio/MS.

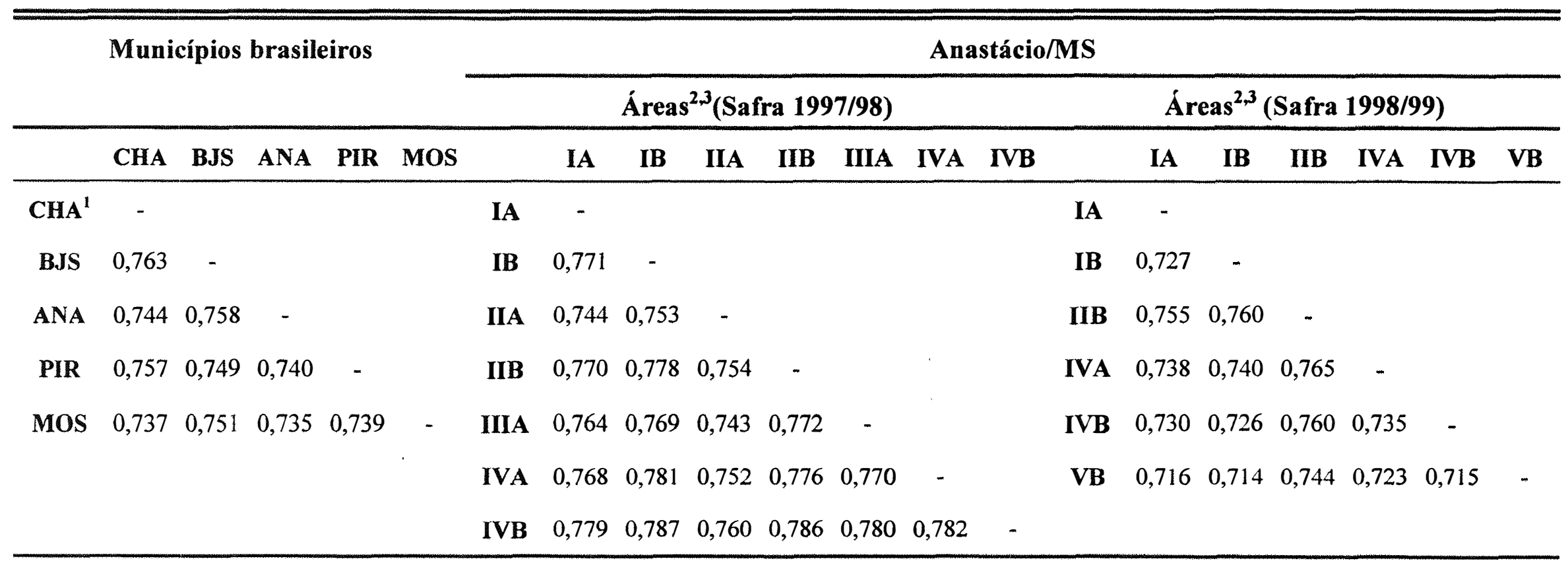

${ }^{1}$ Municípios: CHA - Chapecó/SC; BJS - Bom Jardim da Serra/SC; ANA - Anastácio/MS; PIR - Piracicaba/SP e MOS Mossoró/RN

${ }^{2}$ Áreas I e II - plantio do milho em única safra anual há pelo menos 5 anos; áreas III, IV e V - áreas de pastagem sem plantio de milho há mais de 5 anos, nas quais o milho foi plantado nos anos de 1997/98 e 1998/99;

${ }^{3}$ As letras ao lado da identificação das áreas indicam A - ínicio da safra do milho e B- meio ou final da safra. 


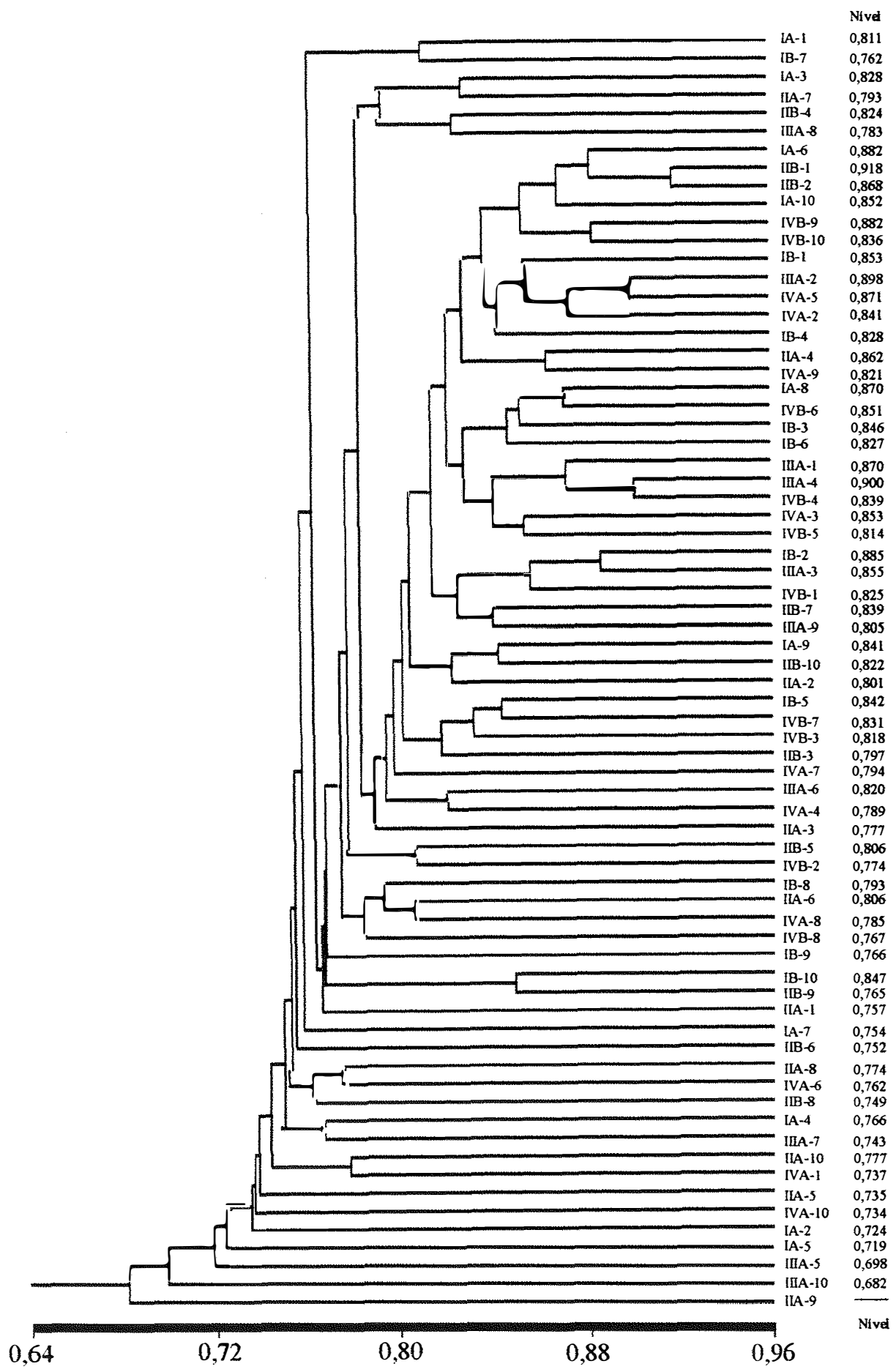

Figura 28. Dendrograma UPGMA baseado no coeficiente de similaridade de Jaccard (J), gerado a partir de marcadores RAPD-PCR de 10 espécimes de Dalbulus maidis de cada uma das 7 populações amostradas no município de Anastácio/MS (áreas IA, IB, IIA, IIB, IIIA, IVA e IVB), na safra 1997/98. 


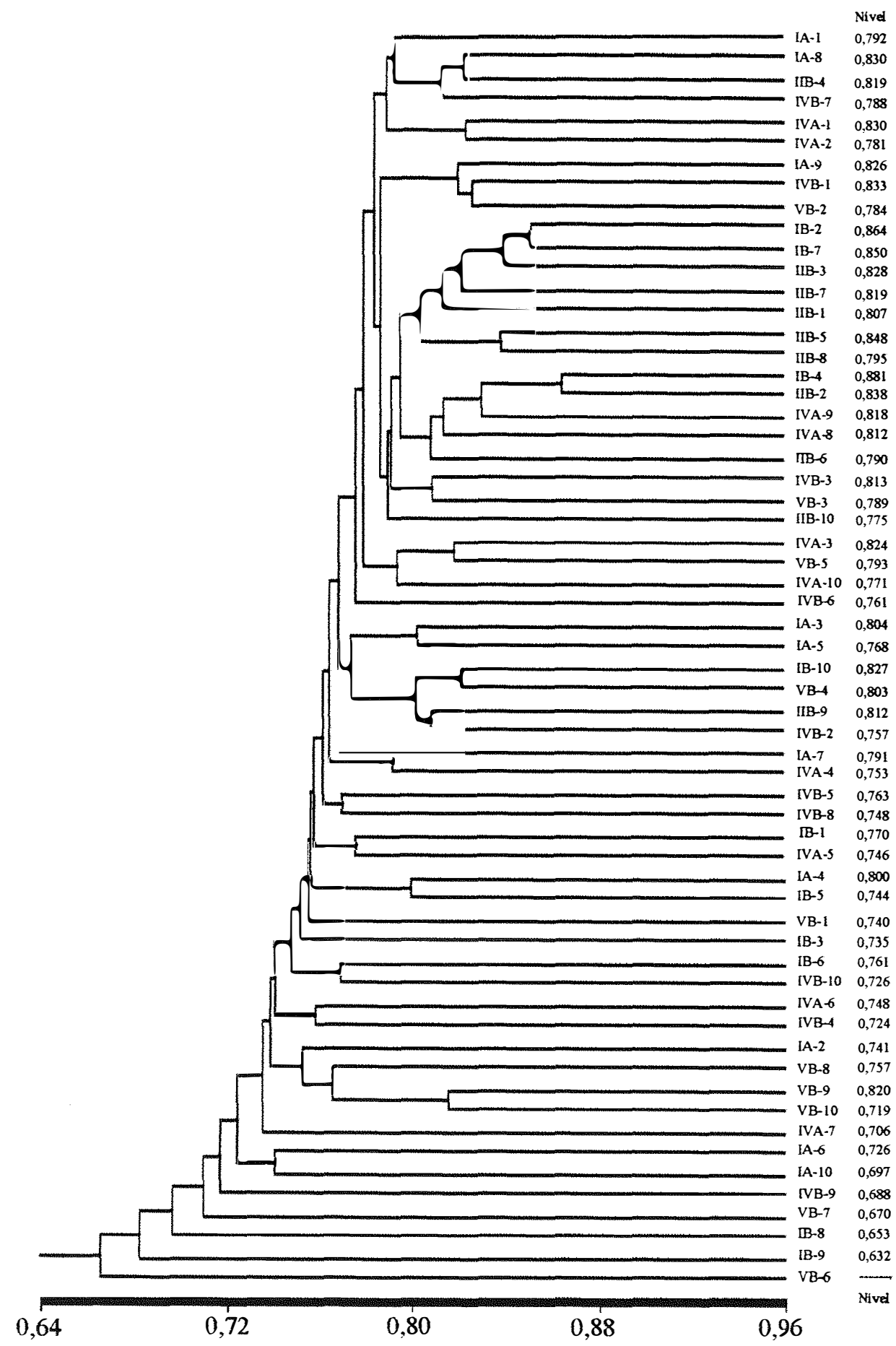

Figura 29. Dendrograma UPGMA baseado no coeficiente de similaridade de Jaccard (J), gerado a partir de marcadores RAPD-PCR de 10 espécimes de Dalbulus maidis de cada uma das 6 populações amostradas no município de Anastácio/MS (áreas IA, IB, IIB, IVA, IVB e VB), na safra 1998/99. 


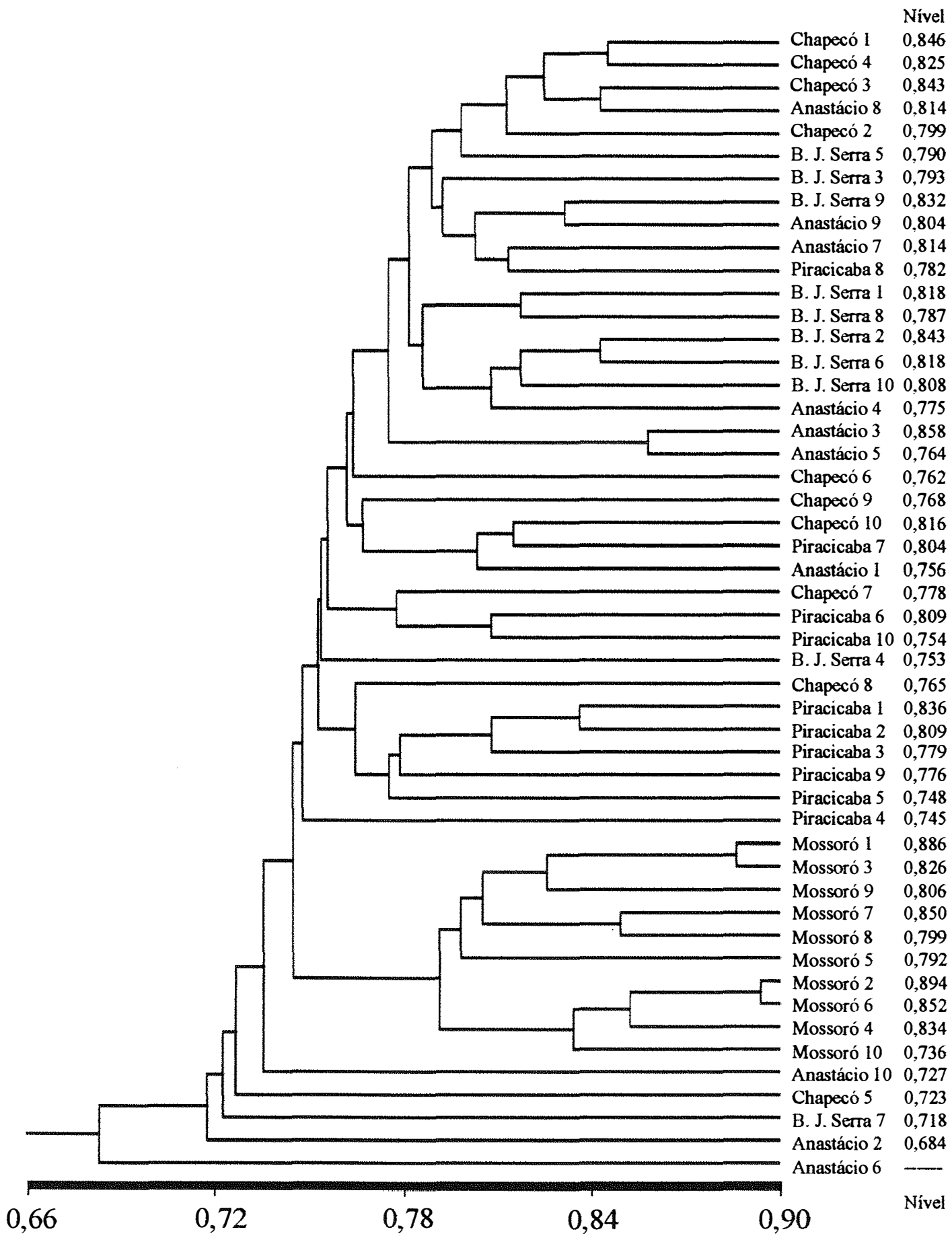

Figura 30. Dendrograma UPGMA baseado no coeficiente de similaridade de Jaccard (J), gerado a partir de marcadores RAPD-PCR de 10 espécimes de Dalbulus maidis de cada uma das 5 populações amostradas nos municípios de Chapecó/SC, Bom Jardim da Serra/SC, Anastácio/MS, Piracicaba/SP e Mossoró/RN. 
A

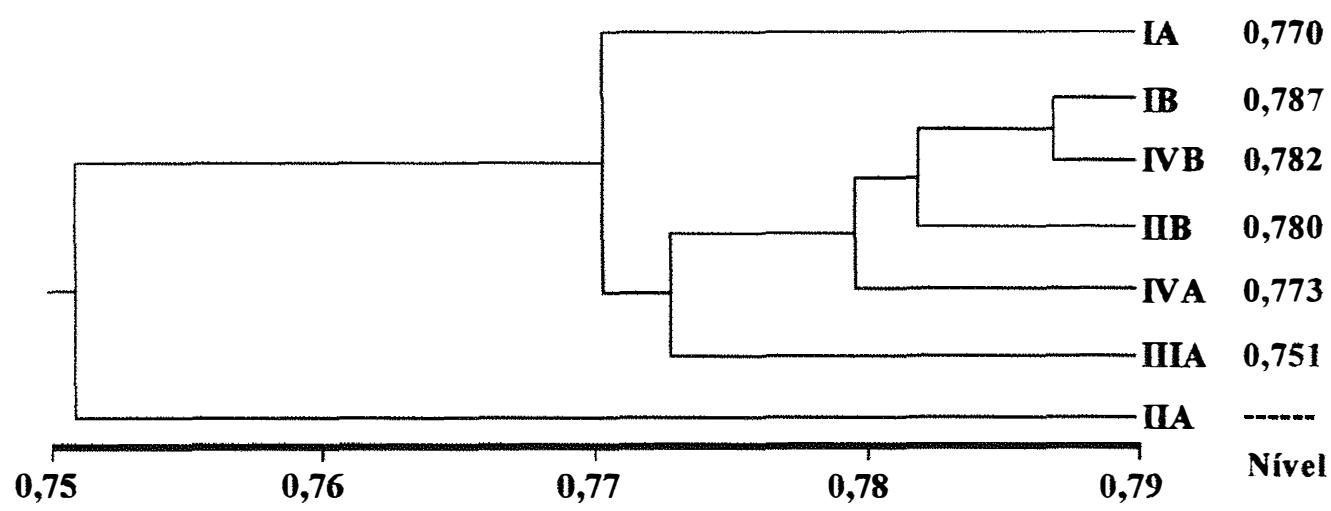

B

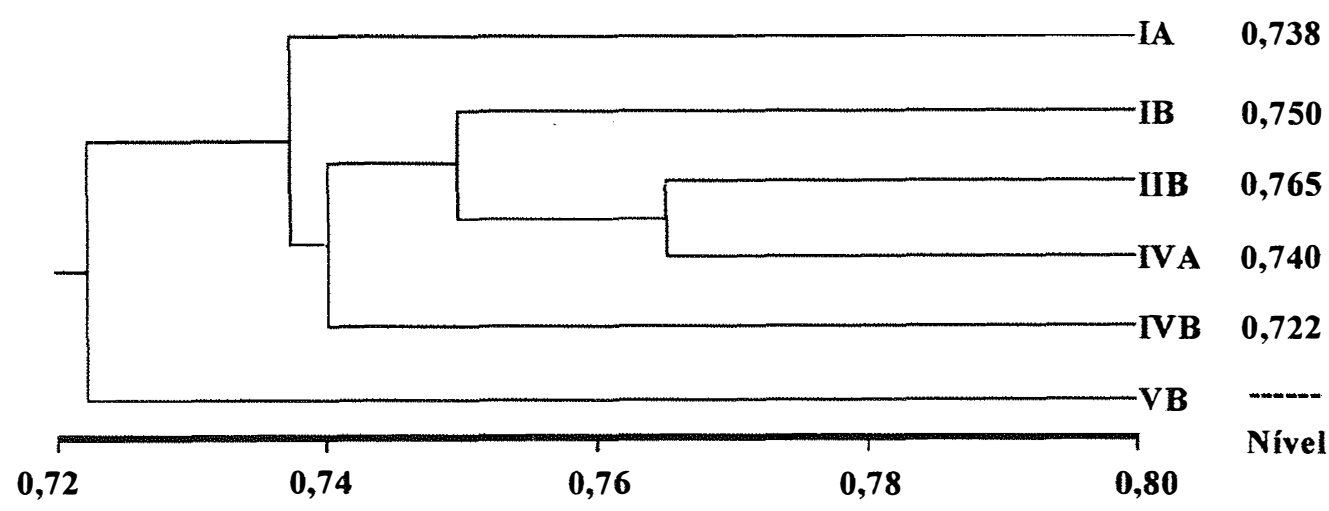

C

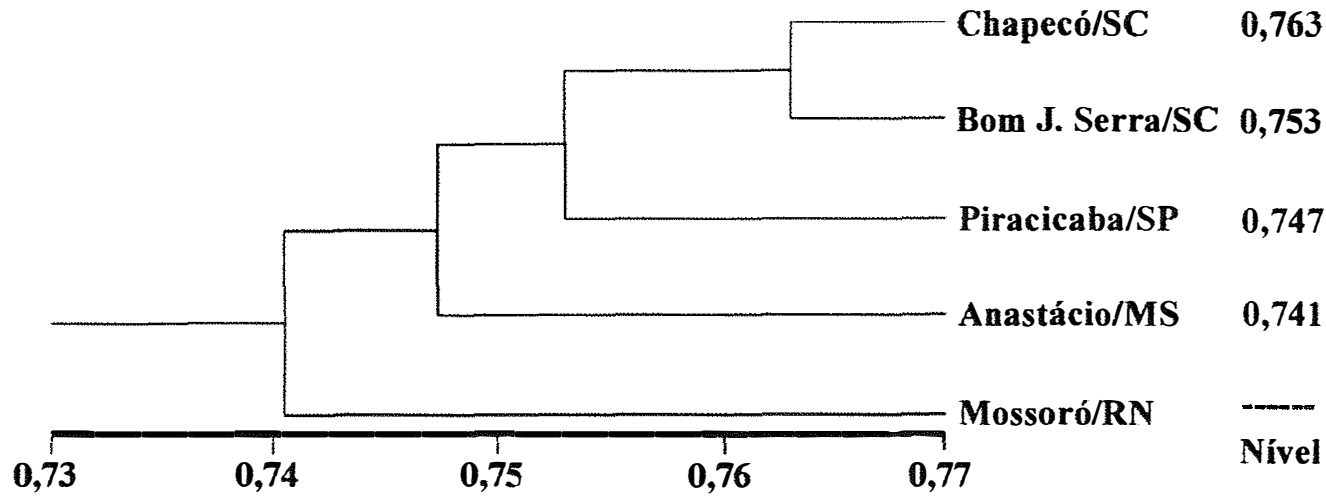

Figura 31. Dendrograma UPGMA baseado no coeficiente de similaridade de Jaccard ( $)$, gerado a partir de marcadores RAPD-PCR para populações de Dalbulus maidis. (A) sete populações coletadas em Anastácio/MS na safra 1997/98; (B) seis populações coletadas em Anastácio/MS na safra 1998/99; e (C) cinco populações coletadas nos municípios de Chapecó/SC, Bom Jardim da Serra/SC, Anastácio/MS, Piracicaba/SP e Mossoró/RN. 


\subsection{DISCUSSÃO}

Embora a técnica RAPD-PCR através do polimorfismo de DNA apresenta-se como uma importante ferramenta para o estudo populacional de insetos, diversos fatores podem alterar a reproducibilidade de produtos RAPD-PCR (Loxdale \& Lushai, 1998; Infante-Malachias et al.,1999). Portanto, a padronização de metodologia para análise do DNA é um passo decisivo para obtenção de resultados confiáveis. Observou-se para $D$. maidis que as diferentes concentrações de DNA utilizadas não diferiram quanto a quantidade e intensidade dos locos amplificados, assim como também observaram Hodge et al. (1995) com o fungo Zoophthora radicans e Koller et al. (1993) com cultivares de maçã. No entanto, para a mosca Cochliomyia hominivorax (Coquerel), houve um decréscimo na intensidade de bandas em concentrações acima de $40 \mathrm{ng}$ e padrões não reproduzíveis abaixo de 0,2 ng (Infante-Malachias et al., 1999). A concentração de $\mathrm{MgCl}_{2}$ afetou significativamente os produtos de amplificação, e mostrou-se como um fator importante na reproducibilidade dos ensaios RAPD-PCR (Infante-Malachias et al., 1999); influência na quantidade de locos amplificados também foi observada para dNTPs e primer. As concentrações de Taq DNA polimerase não mostraram influência significativa na amplificação do DNA de D. maidis. O DNA de cada organismo parece receber influência diferenciada das concentrações dos reagentes utilizados em reações RAPD-PCR. Assim, a otimização desses reagentes deve ser o primeiro passo no estudo de um determinado organismo via RAPD-PCR, bem como a seleção dos primers a serem utilizados (Loxdale et al., 1996).

Neste estudo observou-se que a proporção de locos polimórficos nos três ensaios ficou entre 76,69 e $81,77 \%$ o que demonstra que a variabilidade genética existente dentro da espécie $D$. maidis é relativamente alta. A forma de reprodução tem influência na estrutura genética das populações de insetos (Puterka et al., 1993). Para a cigarrinha $E$. fabae, que tem reprodução sexuada, a proporção de locos polimórficos em estudos com marcadores RAPD-PCR foi de 88\% (Skinner \& Camacho, 1995), por outro lado, em populações partenogenéticas da cochonilha Daktulosphaira vitifoliae (Fitch) no 
Arizona (EUA), esta proporção foi de 14,5\% (Lin et al., 1999). A exemplo do que ocorre em E. fabae (Skinner \& Camacho, 1995), a reprodução sexuada com acasalamentos aleatórios parece ser um dos fatores responsáveis pela manutenção da alta variabilidade genética encontrada em $D$. maidis.

Com relação aos ensaios em nível de microregião, realizados com as populações coletadas em Anastácio/MS, os índices de similaridade foram superiores a 0,71 não havendo uma maior similaridade dentro ou entre as populações, tanto na safra de 1997/98 como em 1998/99. A análise de agrupamento mostrou que os espécimes, independente da área ou data de coleta, agruparam-se aleatoriamente. A região de Anastácio/MS caracteriza-se por um longo contínuo de pastagens, onde o milho, hospedeiro primário de D. maidis, é plantado uma vez por ano em pequenas áreas; este município está localizado a uma distância significativa de grandes regiões produtoras de milho. Nas duas safras, das áreas escolhidas para o estudo em Anastácio/MS, haviam duas onde o milho era plantado uma vez por ano a partir de outubro e duas áreas isoladas onde o milho nunca havia sido plantado. $\mathrm{O}$ aparecimento de $D$. maidis em todas as áreas após o plantio do milho e em outras ocasiões, em grandes picos populacionais, até mesmo quando não havia milho no campo (Capítulo 3), sugere que esta espécie migra a longas distâncias. A ocorrência de migração pode ser um fator detenninante para a grande homogeneidade observada entre as populações de D. maidis coletadas em diferentes áreas em Anastácio/MS. A migração tende a aumentar o fluxo gênico entre populações, contribuindo para a manutenção da variabilidade genética e a perda da correlação entre genética e origem geográfica (Hoole et al., 1999), particularmente onde a ausência de barreiras geográficas permite a chegada de populações de outras regiões. A hipótese de Larsen et al. (1992) de que D. maidis é um migrante local cujas as populações voam para hábitats adjacentes aos campos de milho ao final da safra, retornando a estes campos na safra seguinte, não parece se aplicar a região de Anastácio/MS. A alta similaridade observada entre as populações de Anastácio/MS é mais consistente com a hipótese de migração, já que populações locais e isoladas tendem a apresentar maior divergência genética entre si (Vaughn \& Antolin, 1998). 
No estudo em nível de macroregião, nas cinco populações coletadas em quatro grande regiões brasileiras, a similaridade média dentro das populações foi maior que 0,75, o que sugere que indivíduos de uma mesma população representariam um certo estreitamento genético (Haymer et al., 1997). Os valores de similaridade média entre as populações foram bastante altos e sempre superiores a 0,73 , com exceção da população de Anastácio/MS, em que o índice intrapopulacional em alguns casos foi inferior aos interpopulacionais. Apesar da grande similaridade entre e dentro das populações a análise de agrupamento permitiu a separação dos espécimes de Mossoró/RN em um único grupo, sendo que a média de similaridade dentro desta população mostrou-se a mais alta $(0,81)$, enquanto que os espécimes das outras populações se misturaram. Por outro lado, o agrupamento das populações como um todo mostrou uma certa união das populações por distância geográfica. Oliveira (1996) estudou populações de D. maidis de 27 localidades e quatro regiões brasileiras (Sul, Sudeste, Centro-Oeste e Nordeste), incluindo populações de Piracicaba/SP, Anastácio/MS e Chapecó/SC, tendo constatado diferenças morfológicas significativas entre as populações do Nordeste e do Centro-Sul. O fato de termos observado a separação da população de Mossoró/RN, proveniente do Nordeste do Brasil, das demais populações do Centro Sul, é congruente com as diferenças morfológicas observadas entre as populações destas regiões. Assim, o componente genético parece estar contribuindo para estas diferenças morfológicas, além de fatores ambientais como temperatura, umidade relativa, precipitação e outros (Oliveira et al., 1996). Em relação às outras populações, o fato de os espécimes terem se misturado, não se agrupando em suas populações originais, mais uma vez reforça a hipótese de que a migração a longas distâncias através de correntes de vento seja parte da estratégia de sobrevivência desta espécie, como tem sido sugerido por alguns autores (Taylor et al., 1993; Capítulo 3), proporcionando uma maior troca gênica entre estas populações. Talvez exista algum tipo de barreira geográfica, ou mesmo ausência de correntes de vento específicas entre a região Nordeste e o Centro Sul, impedindo que estas populações se misturem, o que levaria a diferenciações genéticas entre as mesmas. Triplehorn et al.(1990), através de estudos com isoenzimas, encontraram maior similaridade entre duas populações de $D$. maidis, uma próxima à cidade do México e 
outra mais ao sul do México, do que com as demais populações, e sugeriram que a similaridade era devido ao fato desta ser uma possível rota migratória para a cigarrinhado-milho na entressafra da cultura.

A cigarninha-do-milho tem como centro de origem o México (Nault \& DeLong, 1980) e de lá espalhou-se pelas Américas acompanhando a própria disseminação do milho, seu hospedeiro primário. Maior heterogeneidade são esperadas entre as populações dentro de seus centros de origem (Baruffi et al., 1995; InfanteMalachias et al., 1999). O fato das populações do Brasil analisadas apresentarem índices de similaridade altos pode ser também conseqüência de que todas as populações aqui existentes são descendentes de populações vindas do México as quais trouxeram apenas parte da variabilidade genética lá existente.

A técnica de RAPD-PCR mostrou-se bastante promissora para estudos com populações de $D$. maidis, provendo de forma rápida e eficiente uma grande quantidade de informações que podem servir de base para explicar variações morfológicas entre populações e dar sustentação à hipótese migratória para esta espécie. Estudos mais abrangentes envolvendo um maior número de populações, principalmente da região Nordeste do Brasil, são necessários para que se possa afimar que estas populações são realmente isoladas das do Centro-Sul, bem como investigar as possíveis causas deste isolamento como, por exemplo, a existência de algum tipo de barreira geográfica ou mesmo a ausência de correntes de vento, as quais são primordiais para movimentos de longas distâncias por insetos diminutos como D. maidis. 


\section{COMPARAÇÃO DE MÉTODOS DE PRESERVAÇÃO DE Dalbulus maidis (DeLONG \& WOLCOTT) (HEMIPTERA: CICADELLIDAE) PARA USO EM RAPD-PCR}

RESUMO - A preservação adequada do DNA de um determinado organismo é um dos pontos cruciais para o sucesso no uso de técnicas moleculares como RAPD-PCR. Foram avaliados oito métodos de preservação da cigarninha-do-milho, Dalbulus maidis: congelamento $\left(-20^{\circ} \mathrm{C}\right)$, álcool etílico $70 \%\left(-20^{\circ} \mathrm{C}\right.$ e temperatura ambiente); álcool etílico absoluto $\left(-20^{\circ} \mathrm{C}\right.$ e temperatura ambiente); secagem ao ar; e preservação em tampão de extração (inseto inteiro e macerado). A intervalos de 10-30 dias, o DNA foi extraído, quantificado e amplificado via RAPD-PCR pelo primer OPA-04, sendo a qualidade do DNA extraído observada em gel de agarose $0,8 \%$. Após 210 dias de preservação, o congelamento $\left(-20^{\circ} \mathrm{C}\right)$ mostrou ser a melhor técnica, não diferindo significativamente do método padrão, DNA extraído de material fresco, em nenhuma das datas avaliadas. Quantidades satisfatórias de DNA também foram obtidas dos insetos conservados em álcool etílico absoluto $\left(-20^{\circ} \mathrm{C}\right)$, álcool etílico $70 \%\left(-20^{\circ} \mathrm{C}\right)$ e tampão de extração (inseto inteiro e macerado). Insetos conservados em álcool etílico absoluto (temperatura ambiente), em álcool etílico 70\% (temperatura ambiente) e secos ao ar mostraram-se impróprios para RAPD-PCR após 120, 60 e 10 dias de armazenamento, respectivamente.

PALAVRAS-CHAVE: cigarrinha-do-milho, marcador molecular, conservação de DNA, técnica de armazenamento. 


\section{COMPARISON OF PRESERVATION METHODS OF Dalbulus maidis (DeLONG $\&$ WOLCOTT) (HEMIPTERA: CICADELLIDAE) FOR USE IN RAPD-PCR}

SUMMARY - The appropriate preservation of DNA of a certain organism is one of the crucial points for the success in the use of molecular techniques like RAPD-PCR. Eight methods of preservation of the corn leafhopper, Dalbulus maidis were tested: freezing $\left(-20^{\circ} \mathrm{C}\right)$, ethyl alcohol $70 \%\left(-20^{\circ} \mathrm{C}\right.$ and room temperature); absolute ethyl alcohol $\left(-20^{\circ} \mathrm{C}\right.$ and room temperature); air-dry; and preservation in extraction buffer (whole and homogenized insect). At intervals of 10 to 30 days, the leafhopper DNA was extracted, quantified and amplified through RAPD-PCR by the primer OPA-04; the quality of extracted DNA was observed on a $0,8 \%$ agarose gel. After 210 days of preservation, freezing $\left(-20^{\circ} \mathrm{C}\right)$ showed to be the best method, not differing significantly from the control (extracted DNA of fresh specimens) on any of the evaluation dates. Satisfactory quantities of DNA were also obtained from insects conserved in absolute ethyl alcohol $\left(-20^{\circ} \mathrm{C}\right)$, ethyl alcohol $70 \%\left(-20^{\circ} \mathrm{C}\right)$ and extraction buffer (whole and homogenized insect). Insects conserved in absolute ethyl alcohol (room temperature), ethyl alcohol $70 \%$ (room temperature) or air-dry conditions were inappropriate for RAPD-PCR after 120,60 and 10 days of storage, respectively.

KEY WORDS: Corn leafhopper, molecular marker, DNA conservation, storage technique.

\subsection{INTRODUÇÃO}

Técnicas moleculares tornaram-se ferramentas importantes no estudo genético de populações naturais de vários organismos. Entre elas está a técnica de DNA polimórfico amplificado ao acaso ("Random Amplified Polymorphic DNA" - RAPD), desenvolvida de forma independente por dois grupos de pesquisadores nos EUA (Welsh 
\& McClelland, 1990; Willians et al., 1990). Embora algumas técnicas baseadas na reação da polimerase em cadeia ("Polimerase Chain Reaction" - PCR) (Saiki et al., 1988) produzam resultados satisfatórios utilizando-se DNA em pequenas quantidades e com algum grau de degradação (Reiss et al., 1995), outras, como RAPD, exigem um DNA íntegro, sendo que espécimes frescos constituem a melhor fonte de material genético para este tipo de estudo. É comum em Entomologia o intercâmbio de materiais entre pesquisadores e também a coleta de espécimes em regiões distantes. No entanto, a manutenção de espécimes vivos até o momento do processamento visando análise genética é inviável na maioria dos casos. Assim, torna-se necessário que estes insetos sejam mortos e convenientemente conservados até o momento de sua manipulação em laboratório.

Alguns estudos têm sido realizados para determinar o efeito de diferentes métodos de preservação na quantidade e qualidade do DNA (Bramwell \& Burns 1988; Goelz et al., 1985; Smith et al., 1987); entretanto, a maioria deles foi realizada com tecidos de vertebrados, sendo que os resultados não são necessariamente aplicáveis a insetos (Logan, 1999; Post et al., 1993). Alguns métodos de preservação têm sido testados para insetos, como solução de Carnoy, silica gel, etanol, metanol, propanol, etil acetato, etileno glicol, formalina, secagem ao ar, amil acetato, xileno, congelamento, acetona, tampão de extração, entre outros (Austin \& Dillon, 1997; Dillon et al., 1996; Logan, 1999; Post et al., 1993; Reiss et al., 1995), mas os resultados mostraram certas diferenças dependendo do grupo de insetos ou mesmo do estádio de desenvolvimento estudado, o que dificulta e torna questionável uma extrapolação de resultados entre diferentes grupos taxonômicos (Dillon et al., 1996).

O presente estudo teve por objetivo comparar alguns métodos simples de preservação da cigarrinha-do-milho, Dalbulus maidis (DeLong \& Wolcott), visando estudos de variabilidade genética em populações desse inseto, a partir de espécimes coletados em regiões distantes. Avaliou-se a eficiência quantitativa e qualitativa de preservação do DNA dos espécimes por cada um dos métodos, após sucessivos períodos de armazenamento, bem como a performance das amostras em relação à técnica de RAPD-PCR. 


\subsection{MATERIAL E MÉTODOS}

Os espécimes de $D$. maidis utilizados neste estudo foram obtidos de uma colônia formada a partir de indivíduos coletados em Piracicaba/SP e mantida sobre plântulas de milho, em laboratório, por mais de 15 gerações. Todos os espécimes foram avaliados previamente quanto a uma possível contaminação por parasitóides.

\subsubsection{Métodos de preservação}

Oito métodos de preservação foram utilizados neste estudo. Espécimes de $D$. maidis foram coletados vivos e submetidos, simultaneamente, a cada um dos seguintes métodos de preservação: (A) congelamento dos insetos em freezer $\left(-20^{\circ} \mathrm{C}\right)$; (B) álcool etílico $70 \%$ (temperatura ambiente); (C) álcool etílico $70 \%\left(-20^{\circ} \mathrm{C}\right)$; (D) álcool etílico absoluto (temperatura ambiente); (E) álcool etílico absoluto $\left(-20^{\circ} \mathrm{C}\right) ;(\mathrm{F})$ insetos mantidos a seco em placa de Petri (temperatura ambiente); $(G)$ insetos inteiros mantidos individualmente em tubos de microcentrífuga com $300 \mu \mathrm{l}$ de tampão de extração (200 $\mathrm{mM}$ Tris- $\mathrm{HCl}, \mathrm{pH} 8,0 ; 250 \mathrm{mM} \mathrm{NaCl} ; 25 \mathrm{mM}$ EDTA e 1\% SDS) (temperatura ambiente); e (H) insetos macerados mantidos individualmente em tubos de microcentrífuga com $300 \mu$ l de tampão de extração (temperatura ambiente).

\subsubsection{Extração do DNA}

A intervalos de tempo de 10 a 30 dias, três espécimes de $D$. maidis de cada um dos oito métodos de preservação foram retirados e submetidos à extração do DNA genômico total, seguindo-se o protocolo modificado de Raeder \& Broda (1985). Como 
padrão de comparação foi extraído, ao final do ensaio (210 dias), o DNA de três espécimes frescos. Os espécimes foram colocados em tubos de microcentrífuga (1,5 ml), macerados em presença de $300 \mu \mathrm{l}$ de tampão de extração e incubados a $65^{\circ} \mathrm{C}$ por $30 \mathrm{~min}$. Em seguida, foram feitas três extrações orgânicas com fenol, fenol:clorofórmio:álcool isoamílico (25:24:1) e clorofórmio:álcool isoamílico (24:1). Nas três extrações acrescentou-se $300 \mu \mathrm{l}$ de cada solvente, centrifugou-se a $14.800 \mathrm{~g}$ por $10 \mathrm{~min}$ e recolheu-se o sobrenadante. O DNA foi precipitado da fase aquosa ao final da extração, pela adição de igual volume de álcool isopropílico e de $\mathrm{NaCl}$ para uma concentração final de $0,3 \mathrm{M}$. As amostras foram mantidas em freezer $\left(-20^{\circ} \mathrm{C}\right)$ por no mínimo $12 \mathrm{~h}$. A sedimentação foi feita por centrifugação a 14.800 g por $10 \mathrm{~min}$. O DNA foi lavado com álcool etílico 70\%, seco ao ar, ressuspendido em $20 \mu \mathrm{l}$ de TE (10 mM de Tris e $1 \mathrm{mM}$ de EDTA; pH 8,0) e armazenado em freezer $\left(-20^{\circ} \mathrm{C}\right)$ até a quantificação. No caso dos métodos de preservação que envolveram o uso de álcool como fixador, os espécimes foram submetidos a um pré-tratamento para reidratação antes da extração, que consistiu na lavagem dos espécimes em água destilada por 5 min e em TE por no mínimo $1,5 \mathrm{~h}$ sob agitação.

O DNA total de cada espécime foi quantificado pela fluorescência de uma alíquota de $2 \mu \mathrm{l}$ de DNA extraído após mistura com o pigmento Hoescht 33258 Dye (Cesarone et al., 1979), utilizando-se fluorímetro Versa Fluor (Bio-Rad Laboratories, Hercules, CA 94547, USA). Após a quantificação, as amostras de DNA foram diluídas em TE para $3 \mathrm{ng} / \mu \mathrm{l}$. Quantidades muito pequenas de DNA nas amostras (geralmente $<1$ ng) não puderam ser medidas com precisão pelo fluorímetro e ocasionalmente foram obtidas leituras negativas. Nestes casos, a quantidade de DNA foi corrigida para zero. Para a observação da integridade do DNA extraído, uma alíquota de $1 \mu 1$ do DNA total das amostras, diluída em $6 \mu \mathrm{l}$ de tampão de corrida, foi analisada por eletroforese em tampão TBE (100 mM Tris; $83 \mathrm{mM} \mathrm{H}_{3} \mathrm{Bo}_{3}$ e $1 \mathrm{mM}$ EDTA). A eletroforese foi conduzida a $3,5 \mathrm{~V} / \mathrm{cm}$ por $1 \mathrm{~h}$, em gel de agarose $0,8 \%$ corado com brometo de etídio ( 1 $\mu \mathrm{g} / \mathrm{ml}$ de gel) e fotografado sob luz U.V. com filme branco e preto NeoPan ASA 100 (Fuji Photo Film da Amazônia Ltda, Manaus, AM 69075-000, Brasil). 


\subsubsection{Amplificação via RAPD-PCR}

Nas reações RAPD utilizou-se o primer OPA-04 (5'-AATCGGGCTG-3') (Operon Technologies, Alameda, CA 94501, USA). A amplificação foi realizada em um volume final de $20 \mu \mathrm{l}$ contendo $6 \mathrm{ng}$ de DNA; $4 \mathrm{mM}$ de $\mathrm{MgCl}_{2} ; 0,25 \mathrm{mM}$ de dNTP; 0,3 $\mu \mathrm{M}$ do primer e 1 unidade de Taq DNA polimerase, adicionando-se ao final $30 \mu \mathrm{d}$ de óleo mineral. Como controle negativo foi utilizada uma amostra que continha todos os reagentes, exceto DNA de cigarrinha. As reações foram realizadas em termociclador PTC-100 (MJ Research, Inc., Watertown, MA 02172, USA) nas seguintes condições de amplificação: $92^{\circ} \mathrm{C}$ por $5 \min \left(1\right.$ ciclo), $92^{\circ} \mathrm{C}$ por $40 \mathrm{~s}, 40^{\circ} \mathrm{C}$ por $1,5 \min$ e $72^{\circ} \mathrm{C}$ por 2 $\min \left(40\right.$ ciclos) e $72^{\circ} \mathrm{C}$ por $5 \min (1$ ciclo $)$.

Após a adição de $3 \mu \mathrm{l}$ do tampão de corrida, $20 \mu \mathrm{l}$ das amostras amplificadas foram aplicados em gel de agarose $1,4 \%$, procedendo-se a eletroforese em tampão TBE por 3,5 h. A eletroforese e a captura fotográfica foram efetuadas como descrito anteriormente. Realizou-se também a captura pelo sistema de documentação de gel "Eagle Eye II" (Stratagene, La Jolla, CA 92037, USA), para estimativa dos pesos moleculares dos locos amplificados.

\subsubsection{Análise dos dados}

Com os dados de quantidade de DNA total de cada espécime, para cada uma das datas de extração, realizou-se análise de variância (ANOVA); as médias foram comparadas pelo teste de Tukey ( $\mathrm{P} \leq 0,05)$, através do programa "Statistical Analysis System" V. 6.08 (SAS Institute, 1993). Devido à heterogeneidade de variância, os dados de cada data de extração foram submetidos a um tipo de transformação que melhor os ajustassem ao modelo normal; as transformações utilizadas foram: $\log (x+1), \sqrt{x+1}$, 
$1 / x+1,(x+1)^{-2}$ e $1 / \sqrt{x+1}$. Para a comparação de cada um dos métodos de preservação com o método padrão (quantidade de DNA obtida de espécimes frescos), utilizou-se o teste de Dunnett $(\mathrm{P} \leq 0,05)$ (SAS Institute, 1993).

\subsection{RESULTADOS}

Baseando-se nas leituras obtidas pelo fluorímetro (Tabelas 6 e 7), o método de extração utilizado neste estudo mostrou-se eficiente para $D$. maidis, já que as quantidades de DNA obtidas foram suficientes para realização de análises por RAPDPCR.

A análise de variância (ANOVA), seguida do teste de Tukey, mostrou que após 1 dia do início do armazenamento todos os tratamentos forneceram quantidades de DNA semelhantes ao padrão (Tabela 6). A partir dos 10 dias, a quantidade de DNA extraído de material seco ao ar, em álcool etílico absoluto e álcool etílico $70 \%$, ambos à temperatura ambiente, mostraram-se significativamente inferiores ao método padrão. $\mathrm{O}$ método de congelamento não apresentou diferença significativa em relação ao método padrão durante todo o experimento. Os demais métodos mostraram certa irregularidade e diferiram significativamente do método padrão em algumas datas de extração: álcool etílico $70 \%\left(-20^{\circ} \mathrm{C}\right)$ aos $10,80,120$ e 210 dias; álcool etílico absoluto $\left(-20^{\circ} \mathrm{C}\right)$ aos 10,60 e 80 dias; tampão de extração (inseto inteiro) aos 20, 40, 60, 70, 80, 90, 100 e 210 dias e tampão de extração (inseto macerado) aos 80 e 100 dias. O teste de Dunnett, que apenas compara os tratamentos com o padrão, confirmou estes resultados. 
Tabela 6. Quantidades médias ( \pm desvio padrão da média) de DNA genômico total (ng DNA/ $\mu \mathrm{l} \mathrm{TE}$ ) extraída por espécime de $D$. maidis, após períodos de armazenamento de 1 a 70 dias, sob diferentes métodos de preservação.

\begin{tabular}{|c|c|c|c|c|c|c|c|c|}
\hline \multirow[b]{2}{*}{ Método } & \multicolumn{8}{|c|}{ Periodo de armazenamento (dias) } \\
\hline & 1 & 10 & 20 & 30 & 40 & 50 & 60 & 70 \\
\hline Padrão-espécimes frescos & $105 \pm 5 a^{3}$ & $105 \pm 5 a^{3}$ & $105 \pm 5 a^{3}$ & $105 \pm 5 a^{3}$ & $105 \pm 5 a^{3}$ & $105 \pm 5 a^{3}$ & $105 \pm 5 a^{3}$ & $105 \pm 5 \mathrm{a}^{3}$ \\
\hline Congelamento $\left(-20^{\circ} \mathrm{C}\right)$ & $76 \pm 5 a^{*}$ & $71 \pm 16 \mathrm{ab}^{*}$ & $65 \pm 8 \mathrm{ab}^{*}$ & $84 \pm 15 \mathrm{ab}^{*}$ & $101 \pm 1 a^{*}$ & $57 \pm 23 \mathrm{ab}^{*}$ & $118 \pm 2 a^{*}$ & $90 \pm 20 a^{*}$ \\
\hline T. E. (ambiente) ${ }^{1}$ & $54 \pm 9 a^{*}$ & $58 \pm 5 \mathrm{ab}^{*}$ & $79 \pm 9 a^{*}$ & $38 \pm 15 \mathrm{abc} *$ & $79 \pm 25 \mathrm{ab}^{*}$ & $45 \pm 6 \mathrm{ab}^{*}$ & $95 \pm 16 \mathrm{ab}^{*}$ & $76 \pm 25 a^{*}$ \\
\hline T. E. (ambiente) ${ }^{2}$ & $60 \pm 11 a^{*}$ & $56 \pm 20 \mathrm{ab}^{*}$ & $35 \pm 16 b c$ & $33 \pm 10 \mathrm{abc}^{*}$ & $31 \pm 11 \mathrm{bcd}$ & $49 \pm 15 \mathrm{ab}^{*}$ & $28 \pm 2 \mathrm{dc}$ & $30 \pm 8 b c$ \\
\hline Álcool absoluto $\left(-20^{\circ} \mathrm{C}\right)$ & $73 \pm 15 a^{*}$ & $39 \pm 4 b$ & $60 \pm 4 \mathrm{ab}^{*}$ & $117 \pm 3 \mathrm{a}^{*}$ & $72 \pm 18 a b c^{*}$ & $80 \pm 17 a^{*}$ & $33 \pm 9 \mathrm{bcd}$ & $50 \pm 1 \mathrm{ab}^{*}$ \\
\hline Álcool $70 \%\left(-20^{\circ} \mathrm{C}\right)$ & $78 \pm 7 a^{*}$ & $39 \pm 5 b$ & $52 \pm 3 \mathrm{ab}^{*}$ & $95 \pm 33 \mathrm{ab}^{*}$ & $43 \pm 7 \mathrm{abcd}^{*}$ & $81 \pm 38 \mathrm{ab}^{*}$ & $79 \pm 35 \mathrm{abc} *$ & $44 \pm 4 \mathrm{ab}^{*}$ \\
\hline Álcool absoluto (ambiente) & $97 \pm 3 a^{*}$ & $36 \pm 11 \mathrm{~b}$ & $14 \pm 2 \mathrm{c}$ & $27 \pm 6 \mathrm{bc}$ & $20 \pm 6 \mathrm{~cd}$ & $15 \pm 8 \mathrm{bc}$ & $22 \pm 4 \mathrm{~cd}$ & $12 \pm 3 \mathrm{~cd}$ \\
\hline Álcool 70\% (ambiente) & $68 \pm 8 a^{*}$ & $24 \pm 6 b c$ & $11 \pm 1 \mathrm{c}$ & $13 \pm 3 \mathrm{~cd}$ & $15 \pm 5 d$ & $8 \pm 1 \quad b c$ & $21 \pm 1 \mathrm{~cd}$ & $4 \pm 2 d$ \\
\hline Seco ao ar & $110 \pm 2 a^{*}$ & $5 \pm 4 \quad c$ & $0 \mathrm{~d}$ & $0 \mathrm{~d}$ & 0 & $\mathrm{c}$ & $0 \mathrm{~d}$ & 0 \\
\hline $\mathbf{P}$ & 0,0001 & 0,0001 & 0,0001 & 0,0001 & 0,0003 & 0,0001 & 0,0001 & 0,0001 \\
\hline $\mathbf{F}$ & 9,5 & 28,7 & 18,9 & 17,2 & 7,0 & 10,8 & 39,8 & 124,5 \\
\hline Graus de liberdade & 8 e 18 & 8 e 18 & 8 e 18 & 8 e 18 & 8 e 18 & 8 e 18 & 8 e 18 & 8 e 18 \\
\hline
\end{tabular}

${ }^{1}$ Tampão de extração (inseto macerado).

${ }^{2}$ Tampão de extração (inseto inteiro).

${ }^{3}$ Médias seguidas de mesma letra na coluna não diferem entre si pelo teste de Tukey $(\mathrm{P} \leq 0,05)$.

* Indica nenhuma diferença significativa em relação ao método padrão (DNA extraído de espécimes frescos) pelo teste de Dunnett $(\mathrm{P} \leq 0,05)$ 
Tabela 7. Quantidades médias ( \pm desvio padrão da média) de DNA genômico total (ng DNA/ $\mu$ l TE) extraída por espécime de $D$. maidis, após períodos de armazenamento de 80 a 210 dias, sob diferentes métodos de preservação.

\begin{tabular}{|c|c|c|c|c|c|c|c|c|}
\hline \multirow[b]{2}{*}{ Método } & \multicolumn{8}{|c|}{ Período de armazenamento (dias) } \\
\hline & 80 & 90 & 100 & 120 & 140 & 160 & 180 & 210 \\
\hline Padrão-espécimes frescos & $105 \pm 5 a^{3}$ & $105 \pm 5 \mathrm{a}^{3}$ & $105 \pm 5 \mathrm{ab}^{3}$ & $105 \pm 5 a^{3}$ & $105 \pm 5 \mathrm{a}^{3}$ & $105 \pm 5 \mathrm{a}^{3}$ & $105 \pm 5 \mathrm{a}^{3}$ & $105 \pm 5 \mathrm{a}^{3}$ \\
\hline Congelamento $\left(-20^{\circ} \mathrm{C}\right)$ & $73 \pm 8 \mathrm{ab}^{*}$ & $128 \pm 1 \mathrm{a}^{*}$ & $131 \pm 1 \mathrm{a}^{*}$ & $94 \pm 18 \mathrm{ab}^{*}$ & $140 \pm 2 a^{*}$ & $96 \pm 11 \mathrm{a}^{*}$ & $100 \pm 1 a^{*}$ & $102 \pm 4 a^{*}$ \\
\hline T. E. (ambiente) $)^{1}$ & $37 \pm 9 \mathrm{~cd}$ & $73 \pm 15 a^{*}$ & $28 \pm 3 \mathrm{dc}$ & $67 \pm 15 \mathrm{ab}^{*}$ & $34 \pm 7 a^{*}$ & $61 \pm 8 a^{*}$ & $92 \pm 18 a^{*}$ & $64 \pm 3 \mathrm{ab}^{*}$ \\
\hline T. E. (ambiente) $)^{2}$ & $34 \pm 3 \mathrm{~cd}$ & $23 \pm 9 b$ & $19 \pm 6 \mathrm{~d}$ & $67 \pm 16 \mathrm{ab}^{*}$ & $41 \pm 5 a^{*}$ & $62 \pm 12 a^{*}$ & $53 \pm 5 a^{*}$ & $37 \pm 5 \mathrm{c}$ \\
\hline Álcool absoluto $\left(-20^{\circ} \mathrm{C}\right)$ & $46 \pm 4$ bc & $65 \pm 31 a^{*}$ & $59 \pm 17 b^{*}$ & $59 \pm 3 \mathrm{ab}^{*}$ & $44 \pm 3 a^{*}$ & $68 \pm 13 a^{*}$ & $88 \pm 9 a^{*}$ & $82 \pm 4 a^{*}$ \\
\hline Álcool $70 \%\left(-20^{\circ} \mathrm{C}\right)$ & $43 \pm 14 \mathrm{bcd}$ & $66 \pm 3 a^{*}$ & $49 \pm 4 \mathrm{bc}^{*}$ & $40 \pm 1 \mathrm{~b}$ & $64 \pm 25 a^{*}$ & $59 \pm 19 a^{*}$ & $68 \pm 7 a^{*}$ & $43 \pm 10 b c$ \\
\hline Álcool absoluto (ambiente) & $20 \pm 1 \mathrm{~d}$ & $13 \pm 3 b$ & $14 \pm 3 d$ & $8 \pm 1 \quad c$ & $4 \pm 2 \quad b c$ & $3 \pm 2 \quad b c$ & $4 \pm 2 \quad b$ & $3 \pm 1 \quad d$ \\
\hline Álcool 70\% (ambiente) & $3 \pm 2$ e & $2 \pm 1 \quad c$ & $2 \pm 2 \mathrm{e}$ & $3 \pm 1 \quad d$ & $2 \pm 2 \quad b$ & $4 \pm 1 \quad b$ & $2 \pm 1 \quad c$ & $2 \pm 1 \quad d$ \\
\hline Seco ao ar & $0 \mathrm{e}$ & $0 \mathrm{~d}$ & $0 \quad \mathrm{e}$ & $\mathrm{e}$ & 0 & $\mathrm{c}$ & $0 \quad \mathrm{c}$ & $\mathrm{d}$ \\
\hline $\mathbf{P}$ & 0,0001 & 0,0001 & 0,0001 & 0,0001 & 0,0001 & 0,0001 & 0,0001 & 0,0001 \\
\hline $\mathbf{F}$ & 64,3 & 80,5 & 633,3 & 32,5 & 44,9 & 55,9 & 68,2 & 452,4 \\
\hline Graus de liberdade & 8 e 18 & 8 e 18 & 8 e 18 & 8 e 18 & 8 e 18 & 8 e 18 & 8 e 18 & 8 e 18 \\
\hline
\end{tabular}

${ }^{1}$ Tampão de extração (inseto macerado).

${ }^{2}$ Tampão de extração (inseto inteiro).

${ }^{3}$ Médias seguidas de mesma letra na coluna não diferem entre si pelo teste de Tukey $(\mathrm{P} \leq 0,05)$.

* Indica nenhuma diferença significativa em relação ao método padrão (DNA extraído de espécimes frescos) pelo teste de Dunnett $(\mathrm{P} \leq 0,05)$. 
Um exemplo representativo da qualidade do DNA extraído pode ser observado na Figura 32. Com 1 dia após o início do estudo, observou-se uma boa qualidade do DNA extraído em todos os tratamentos (colunas 7-14). Entretanto, nenhuma banda pôde ser visualizada no gel para os tratamentos álcool etílico $70 \%$ (colunas 16, 24 e 32) e álcool etílico absoluto (colunas 18, 26 e 34) sob temperatura ambiente, bem como para espécimes secos ao ar (colunas 20, 28 e 36), após 70, 120 e 210 dias, devido à baixa quantidade de DNA obtida ou à degradação total do ácido nucléico nesses tratamentos.

Com exceção do tratamento em que os espécimes foram conservados a seco, onde a partir dos 10 dias não foram observados produtos de amplificação (Figura 33B, C e D coluna 8), todos os tratamentos mostraram amplificação via RAPD-PCR bastante satisfatória (Figura 33). Foram amplificados de forma consistente um número razoável de locos gênicos, cujos pesos moleculares foram estimados entre 200 e 2.600 pares de base. 
A

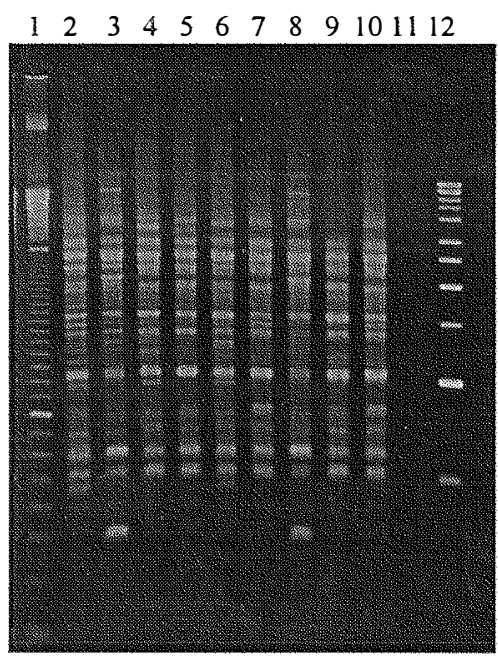

$\mathrm{C}$

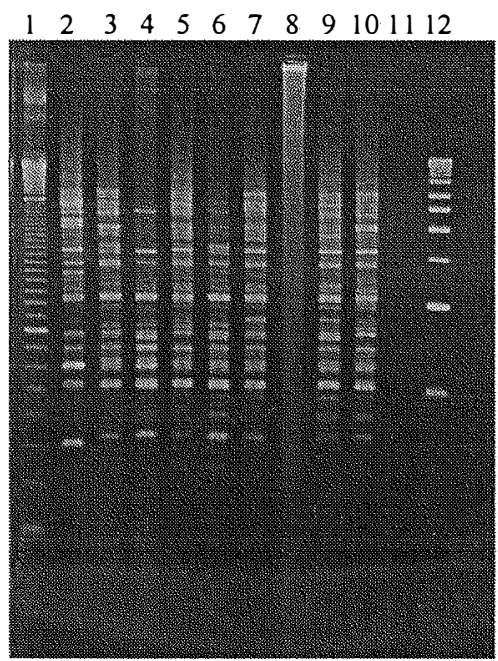

B

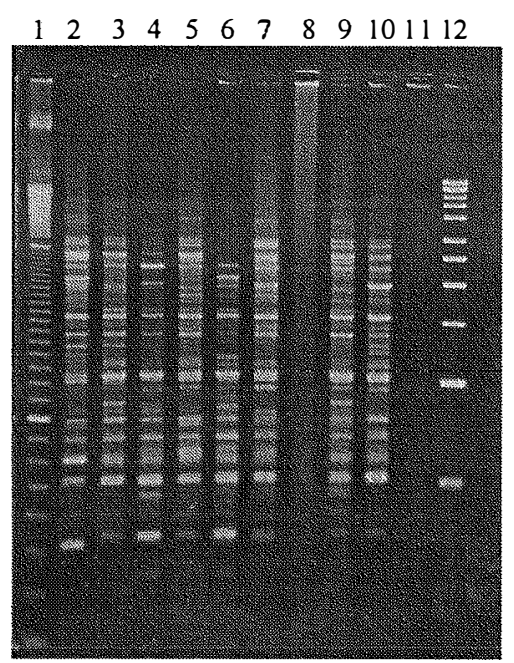

D

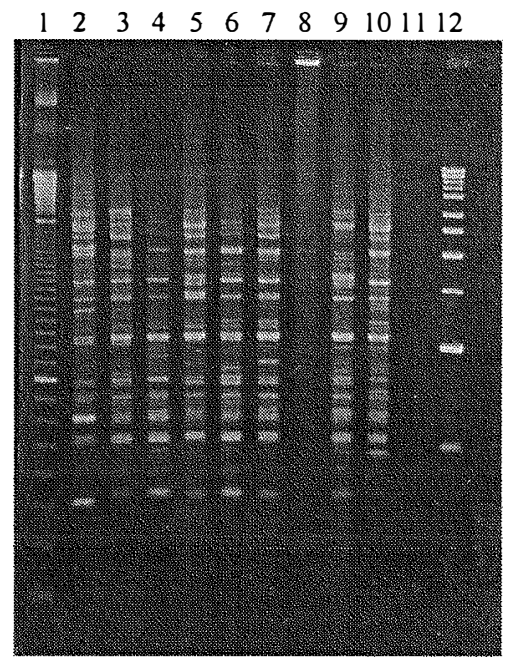

Figura 33. Produtos da amplificação de DNA de Dalbulus maidis via RAPD-PCR pelo primer OPA-04 em gel de agarose 1,4\%, a partir de indivíduos armazenados por períodos sucessivos sob diferentes condições. (A) 1 dia; (B) 70 dias; (C) 120 dias e (D) 210 dias. Coluna 1, marcador (100 base-pair Laedder) (Pharmacia); 2, material fresco; 3, congelamento; 4, álcool etílico 70\% (ambiente); 5, álcool etílico $70 \%\left(-20^{\circ} \mathrm{C}\right) ; 6$, álcool etílico absoluto (ambiente); 7, álcool etílico absoluto $\left(-20^{\circ} \mathrm{C}\right) ; 8$, seco ao ar; 9 , tampão de extração (inseto inteiro) (ambiente); 10, tampão de extração (inseto macerado) (ambiente); 11, controle negativo (todos os componentes da reação menos o DNA) e 12, marcador (Kilobase ${ }^{\mathrm{TM}}$ DNA marker) (Pharmacia). 


\subsection{DISCUSSÃO}

A técnica de RAPD-PCR é uma importante ferramenta na análise da estrutura e diversidade genética em populações naturais (Ferreira \& Grattapaglia, 1996). Diversos estudos baseados em marcadores RAPD-PCR com populações de insetos oriundos do campo têm sido realizados, como por exemplo, análise da diversidade genética entre e dentro de populações do pulgão Diuraphis noxia (Mordivilko) (Puterka et al., 1993), dentro de populações da cigarninha Empoasca fabae (Harris) (Skinner \& Camacho 1995), entre as espécies Myzus persicae (Sulzer) e M. nicotianae Blackman (Margaritopoulos et al., 1998) e detecção de polimorfismo genético em diversas espécies de pulgões (Black et al., 1992). Mas nem sempre é possível obter material fresco para tais estudos, como por exemplo quando se coleta materiais de regiões distantes (Reiss et al., 1995), ou mesmo quando a análise do material não pode ser realizada imediatamente. Muitas técnicas de preservação comumente utilizadas podem não conservar a integridade do DNA, que é um ponto crítico em muitas técnicas de análise genética.

Para ensaios RAPD-PCR utilizando-se D. maidis, quantidades mínimas de DNA, da ordem de $3 \mathrm{ng} / \mu \mathrm{l}$, são suficientes para uma amplificação consistente (Capítulo 2). No entanto, sabendo que estes estudos requerem a utilização de vários primers e computando-se as perdas durante a manipulação das amostras de DNA, neste estudo só foram consideradas satisfatórias as extrações que forneceram no mínimo $160 \mathrm{ng} / 20 \mu \mathrm{l}$. A variação na quantidade de DNA obtida de espécime para espécime dentro dos tratamentos em cada uma das datas de extração pôde, em parte, ser explicada pelo fato de que os indivíduos foram tomados ao acaso, e como as fềmeas nesta espécie são significativamente maiores que os machos (Oliveira, 1996), maiores quantidades de DNA são esperadas para as mesmas, como demonstraram Post et al. (1993) estudando o díptero Simulium damnosum Theobald.

A exemplo de resultados negativos obtidos da extração de DNA de insetos de museu (Dillon et al., 1996; Post et al., 1993), a manutenção de espécimes secos ao ar 
mostrou-se pouco apropriada como método de conservação de $D$. maidis, ocorrendo uma drástica degradação do DNA genômico total nos primeiros 10 dias após a morte dos espécimes, com degradação total após esse período (Tabela 1; Figura 32 colunas 20, 28 e 36).

A preservação em álcool etílico $70 \%$ sob temperatura ambiente propiciou quantidades satisfatórias de DNA até os 60 dias, enquanto que o armazenamento em álcool etílico absoluto, também à temperatura ambiente, mostrou-se adequado até os 120 dias (Tabelas 6 e 7). Para tecido de mamíferos, Smith et al. (1987) relataram a conservação do DNA em álcool etilico por mais de 5 anos, mas este não parece ser o comportamento do DNA de insetos preservados em álcool (Post et al., 1993). Reiss et al. (1995) constataram para o coleóptero Amara glacilis (Mannerheim), fixado em álcool etílico 95\%, um período de preservação do DNA de 73 dias. Para os espécimes de $D$. maidis preservados em álcool etílico à temperatura ambiente, observou-se um gradiente de degradação ao longo do tempo, função da atividade contínua de nucleases (Dessuer et al., 1996), sendo este mais acentuado para álcool etílico 70\%. Algumas variáveis têm se mostrado importantes na quantidade e qualidade de DNA extraído de materiais preservados em álcool etílico, tais como a concentração do álcool, temperatura e tempo de armazenamento (Dillon et al., 1996).

Os métodos álcool etilico $70 \%$ e álcool etílico absoluto a $-20^{\circ} \mathrm{C}$ e espécimes conservados em tampão de extração (insetos inteiros e macerados), apesar de em algumas datas de extração terem apresentado diferenças significativas em relação ao material fresco, permitiram a extração de quantidades satisfatórias de DNA (> 160 ng/20 $\mu$ l) de alta qualidade em todas as datas de extração. A preservação de material em álcool etílico a baixas temperaturas tem sido apontada por alguns autores como um método eficiente de preservação do DNA de diversos grupos de insetos por longos períodos de tempo (Dillon et al., 1996; Post et al., 1993). Reiss et al. (1995) afirmaram que tampão de extração é um método adequado de preservação de DNA, desde de que o inseto seja bem homogeneizado. Neste estudo, observou-se que espécimes homogeneizados quase sempre forneceram quantidades superiores de DNA do que os mantidos inteiros, porém 
este último procedimento mostrou-se também satisfatório como método de preservação de DNA de D. maidis (Tabelas 6 e 7).

$\mathrm{O}$ método do congelamento $\left(-20^{\circ} \mathrm{C}\right)$ foi a forma mais eficiente de armazenamento de espécimes de $D$. maidis, preservando a integridade e fornecendo quantidades de DNA semelhantes ao do material fresco durante todo o estudo (Tabelas 6 e 7). Resultados semelhantes foram obtidos em outros estudos envolvendo os mais diferentes grupos de insetos, como Diptera (Post et al., 1993), Coleoptera (Reiss et al., 1995) e Hymenoptera (Dillon et al., 1996).

As amostras de DNA extraídas nas diferentes datas permitiram, com exceção do material seco ao ar a partir dos 10 dias de armazenamento, a amplificação via RAPDPCR (Figura 33). Para os tratamentos álcool etilico $70 \%$ e absoluto à temperatura ambiente, a não observação de banda correspondente ao DNA genômico total no gel de agarose $0,8 \%$ aos 70, 120 e 210 dias (Figura 32, colunas 16, 18, 24, 26, 32 e 34) foi devido as baixas quantidades de DNA extraído, que a despeito disto foram detectadas pelo fluorímetro (Tabelas 6 e 7) e permitiram amplificação (Figura 33B, C e D). Porém, para álcool etílico $70 \%$ a partir dos 60 dias e álcool etílico absoluto a partir dos 120 dias, a quantidade de DNA extraído $(<160 \mathrm{ng} / 20 \mu \mathrm{l})$, apesar de permitir amplificação, mostrou-se inviável para um ensaio de RAPD-PCR pelo baixo volume de DNA ressuspendido.

De forma prática, para o intercâmbio de espécimes de $D$. maidis visando análise genética ou mesmo quando da coleta de espécimes em locais remotos, pode-se recomendar a preservação em álcool etílico absoluto por um curto espaço de tempo, que mostrou-se um método bastante simples, de baixo custo e que pode ser utilizado diretamente no campo (Reiss et al., 1995). Outra possibilidade é a preservação dos espécimes em tampão de extração (inseto macerado ou inteiro), que permitiu a conservação do DNA por longo período de tempo sem a necessidade de refrigeração. A desvantagem, porém, é que materiais assim preservados não permitiriam estudos dos aspectos morfológicos ou a verificação da presença de parasitóides (Post et al., 1993), uma vez que o material é homogeneizado. Mesmo com o inseto inteiro, devido à ocorrência de lise das células, os espécimes tornariam-se inadequados para tais estudos, 
que via de regra são auxiliares à análise genética e permitem a correta identificação taxonômica do inseto.

No caso de necessidade de conservação dos espécimes em laboratório, sem dúvida, a prática mais recomendada é o congelamento $\left(-20^{\circ} \mathrm{C}\right.$ ou menos) (Dillon et al., 1996; Reiss et al., 1995), por manter a integridade e propiciar quantidades de DNA comparáveis às obtidas de material fresco, por longo período de tempo. Entretanto, outros métodos como álcool etílico absoluto e $70 \%$ à $-20^{\circ} \mathrm{C}$, ou a conservação em tampão de extração também podem ser utilizados. 


\section{EVIDÊNCIA DE DISSEMINAÇÃO DE MOLICUTES DO MILHO A LONGAS DISTÂNCIAS PELO VETOR Dalbulus maidis (DeLONG \& WOLCOTT) (HEMIPTERA: CICADELLIDAE)}

RESUMO - Dalbulus maidis é vetor de dois molicutes associados ao enfezamento do milho, Spiroplasma kunkelii Whitcomb et al. e o fitoplasma do milho. Pelo desconhecimento de plantas hospedeiras alternativas desses patógenos no Brasil, supõese que os mesmos possam se utilizar do vetor para sua sobrevivência e disseminação a longas distâncias na entressafra do milho. Para investigar esta hipótese avaliou-se a infectividade natural de imigrantes de $D$. maidis em plantios de primavera na região de Anastácio/MS, onde não se cultiva o milho na entressafra (outono/inverno), em duas situações distintas: a) áreas onde o milho é plantado anualmente a partir de outubro, e b) áreas onde o milho não era cultivado há vários anos. A avaliação foi realizada em cinco áreas distintas nas safras 1997/98 e 1998/99. Após a emergência do milho foram coletadas cigarrinhas vivas para análise da infectividade por $S$. kunkelii e fitoplasma, através de bioensaios de transmissão. Essas foram confinadas em plântulas sadias de milho, para um período de acesso à inoculação de 4 dias. Posteriormente, as plantas foram avaliadas quanto a sintomas diagnósticos de $S$. kunkelii e por PCR para detecção de fitoplasma. Detectou-se $S$. kunkelii e fitoplasma em 1,6 a $19,7 \%$ e 1,1 a 3,6\% dos indivíduos coletados, respectivamente. $\mathrm{O}$ aparecimento de adultos infectivos logo após a germinação da cultura, inclusive nas áreas onde o milho não era cultivado há vários anos, sugere que os molicutes foram transportados na entressafra por indivíduos migratórios de D. maidis. 
PALAVRAS-CHAVE: enfezamento pálido, enfezamento vermelho, cigarninha-domilho, ecologia.

\section{EVIDENCE OF LONG-DISTANCE SPREAD OF MAIZE MOLLICUTES BY Dalbulus maidis (DeLONG \& WOLCOTT) (HEMIPTERA: CICADELLIDAE)}

SUMMARY-Dalbulus maidis is the vector of two mollicutes associated with corn stunting diseases, Spiroplasma kunkelii Whitcomb et al. and maize bushy stunt phytoplasma. Because alternative host plants are unknown in Brazil, these mollicutes possibly depend on the leafhopper vector for survival and spread during the corn overseason. To investigate this hypothesis, the natural infectivity of $D$. maidis immigrants was evaluated in spring plantings of 1997 and 1998 in the region of Anastácio/MS, where maize is not cultivated in the overseason (autumn/winter), in two different situations: a) areas where maize is planted annually in the spring, and b) areas where maize had not been cultivated for several years. After the crop emergency, live leafhoppers were collected from the plants and tested for infectivity by $S$. kunkelii and phytoplasma, through transmission bioassays. In the lab, the insects were confined on healthy maize seedlings for an inoculation access period of 4 days. Two months later, the test plants were rated for diagnostic symptoms of $S$. kunkelii and tested by PCR for phytoplasma infection. S. kunkelii and phytoplasma were detected in 1.6 to $19.7 \%$ and 1.1 to $3.6 \%$ of the collected individuals, respectively. The appearance of infective adults soon after maize germination, even in the areas where the maize had not been cultivated for several years, suggests that the mollicutes were transported in the overseason by migratory individuals of $D$. maidis.

KEY WORDS: corn stunt spiroplasma, maize bushy stunt phytoplasma, corn leafhopper, overseasoning ecology. 


\subsection{INTRODUÇÃO}

A cigarrinha-do-milho, Dalbulus maidis (DeLong \& Wolcott), única espécie do gênero Dalbulus DeLong relatada em milho (Zea mays L.) no Brasil (Oliveira, 1996), é considerada uma das pragas mais importantes e amplamente distribuídas em milho na América Latina. Embora possa causar danos diretos pela intensa sucção de seiva (Bushing \& Burton, 1974; Waquil, 1997), seu status de praga se deve à capacidade de transmitir, de forma persistente e propagativa, o vírus da risca do milho ("maize rayado fino virus"-MRFV) e os molicutes associados ao enfezamento do milho, Spiroplasma kunkelii Whitcomb et al. ("corn stunt spiroplasma"-CSS) e fitoplasma ("maize bushy stunt phytoplasma"-MBSP) (Nault 1980; 1990).

O enfezamento pálido foi primeiramente relatado na década de 40 no estado americano do Texas (Alstatt, 1945), no entanto, o agente causal só foi identificado na década de 70 como sendo $S$. kunkelli, um procarionte habitante do floema (Davis et al., 1972). O enfezamento vermelho, doença observada pela primeira vez no México na década de 50, teve o seu agente causal identificado na década de 80 como sendo um fitoplasma, também um procarionte habitante do floema (Gordon et al., 1981).

Em muitas regiões, as perdas ocasionadas pela incidência de doenças transmitidas por D. maidis podem ser esporádicas. Entretanto, os danos podem ser bastante severos em áreas cultivadas com variedades suscetíveis e, em especial, onde o milho é cultivado durante todo o ano, principalmente se as plantas forem infectadas ainda no estágio de plântulas. Desde de o sul dos EUA e em toda América Latina, em países como México, El Salvador, Nicarágua e Peru, são registradas relevantes quebras de produção que, em alguns casos, podem chegar a 100\% (Gámez \& León, 1985; Nault, 1990; Nault et al., 1981).

No Brasil, as doenças do milho associadas a vírus e molicutes disseminadas por D. maidis eram consideradas de pouca importância (Kitajima \& Nazareno, 1985; Kitajima et al., 1984). Nos últimos anos, entretanto, a incidência dos enfezamentos do milho aumentou consideravelmente na região Centro-Sul, especialmente em plantios 
tardios (Fernandes \& Balmer, 1990; Silva et al., 1991), havendo relatos de incidências elevadas dos enfezamentos e de MRFV, com perdas expressivas de produção, principalmente nos Estados de São Paulo, Minas Gerais, Goiás e Paraná (Folegatti et al., 1997; Oliveira et al., 1998; Waquil et al., 1996).

Estudos da atividade de vôo e comportamento de fuga de $D$. maidis têm indicado um alto potencial de migração e dispersão para esta espécie (Heady \& Nault, 1985; Taylor et al., 1993), podendo a mesma se deslocar por longas distâncias, como sugere o surto de CSS na Flórida em 1979, provavelmente resultado da migração de cigarrinhas vindas de ilhas do Caribe (Bradfute et al., 1981). A capacidade de migração parece ser especialmente importante para insetos que, como a cigarrinha-do-milho, utilizam apenas milho e teosintos (Zea spp.) como hospedeiro (Barnes, 1954; Nault, 1990). Milho e alguns teosintos são também os únicos hospedeiros naturais relatados para S. kunkelii e MBSP (Nault, 1980). Assim, postula-se que esses molicutes sobrevivam no vetor em áreas e épocas em que o milho não é cultivado, podendo ser disseminados a longas distâncias nessas circunstâncias.

Para investigar a hipótese de sobrevivência dos molicutes $(S$. kunkelii e fitoplasma do milho) em $D$. maidis durante a entressafra do milho, avaliou-se a infectividade natural de indivíduos imigrantes dessa espécie de cigarrinha em plantios de primavera em região onde se cultiva pouco milho, com predominância de pastagens e entressafra prolongada (6-7 meses).

\subsection{MATERIAL E MÉTODOS}

\subsubsection{Características das áreas experimentais e coleta de cigarrinhas}

O estudo foi realizado nas safras 1997/98 e 1998/99 no município de Anastácio/MS, onde não se cultiva o milho no outono/inverno, em duas situações 
distintas: a) áreas I e II: pequenas propriedades ( $\approx 20 \mathrm{ha})$ de subsistência, onde o milho era plantado anualmente a partir de outubro, após a colheita do feijão; e b) áreas III, IV e $\mathrm{V}$ : propriedades $(\approx 70 \mathrm{ha}$ ) cobertas por pastagens perenes, onde o milho não era cultivado há pelo menos 5 anos. As áreas de pastagens (II, IV e V) eram distantes pelo menos 20 $\mathrm{km}$ das áreas com plantio anual de milho (I e II). O município em estudo localiza-se na região oeste do Estado do Mato Grosso do Sul, cuja principal atividade agrícola é a pecuária e fruticultura, estando afastado de grandes áreas produtoras de milho por uma distância superior a $50 \mathrm{~km}$ (Figura 34).

Nos meses de novembro e dezembro de cada safra, o solo foi preparado e adubado (NPK 4:14:8), plantando-se em todas as áreas a variedade de milho BR-106 em talhões de aproximadamente $2000 \mathrm{~m}^{2}$, com exceção da área $\mathrm{V}$, que só foi avaliada na safra 1998/99.

Utilizando-se aspirador bucal, foram coletadas amostras de mais de 50 adultos de $D$. maidis diretamente das plantas de milho, em cada uma das áreas, logo após a emergência da cultura (<30 dias), no meio (60-90 dias) e no final da safra ( $>90$ dias). Os espécimes foram colocados em caixas plásticas contendo uma camada de gesso umedecida no fundo e pedaços de folhas de milho. Este procedimento permitiu o transporte de espécimes vivos até o laboratório em Piracicaba/SP, onde procedeu-se a análise de infectividade natural pelos molicutes através de bioensaios de transmissão.

\subsubsection{Bioensaios de transmissão}

Os insetos coletados foram confinados sobre plantas-teste em gaiolas teladas (D'Arcy \& Nault, 1982), em grupos de 4-7 indivíduos por planta, durante um período de acesso à inoculação (PAI) de 4 dias. Como plantas-teste foram usadas plântulas sadias de milho híbrido XL 330, no estádio de 3-4 folhas, obtidas em potes plásticos de $10 \mathrm{~cm}$ de diâmetro. Após o PAI, as plantas-teste foram transplantadas individualmente para potes plásticos maiores ( $22 \mathrm{~cm}$ de diâmetro), sendo mantidas em casa de vegetação livre 


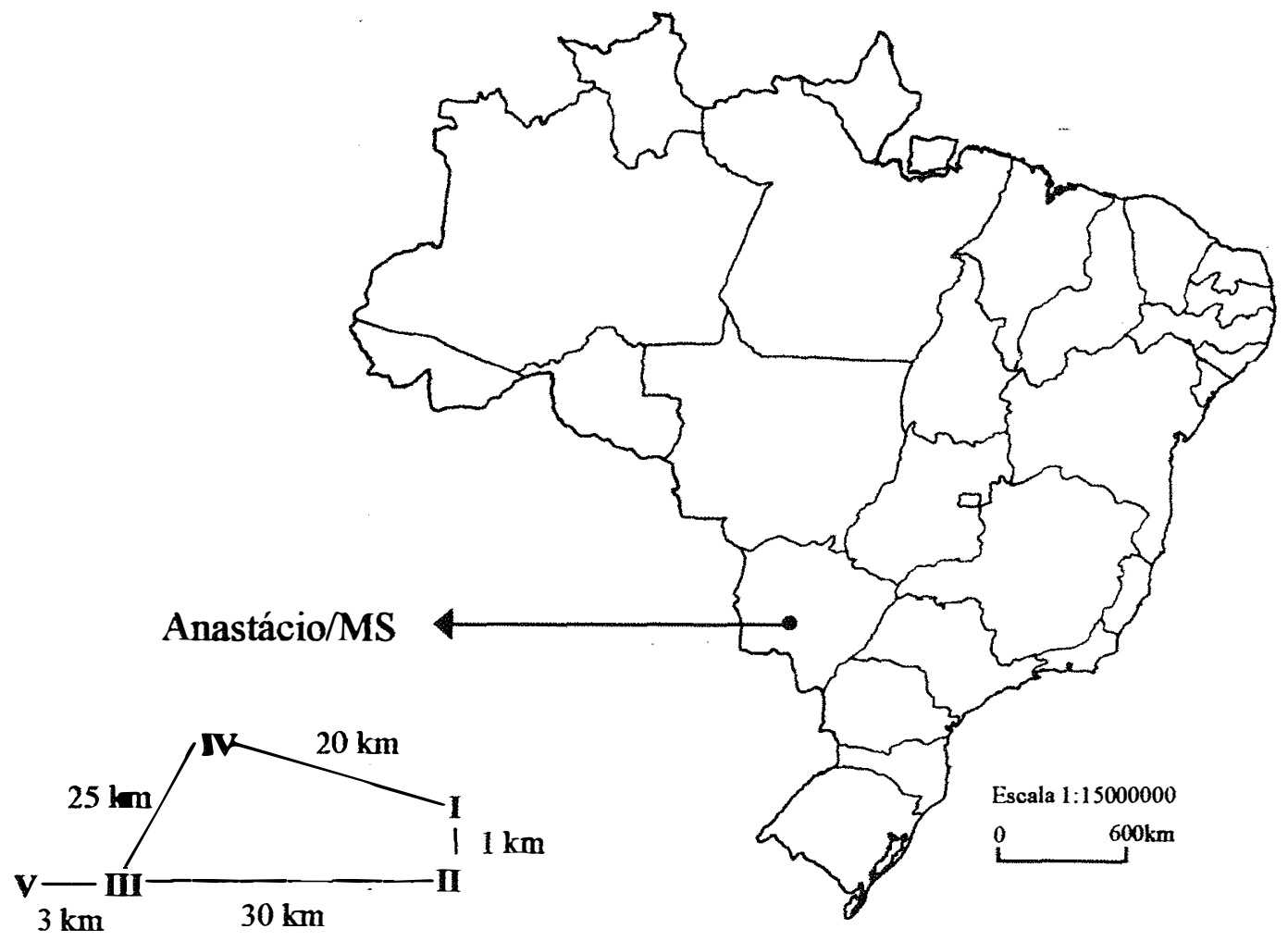

Figura 34. Localização do municipio de Anastácio/MS e das cinco áreas experimentais e distância aproximada entre as mesmas.

de cigarrinhas para desenvolvimento de sintomas. Grupos de três a cinco plantas-teste não inoculadas foram usadas como controle negativo em cada bioensaio de transmissão. As plantas foram pulverizadas com inseticida (mevinfós, $2,5 \mathrm{mi} / 1$ de calda) para se eliminar ninfas de $D$. maidis que eventualmente eclodissem, sendo fertilizadas periodicamente com nitrocálcio. Semanalmente as plantas-teste foram avaliadas quanto à presença de sintomas diagnósticos de $S$. kunkelii (estrias cloróticas no limbo foliar) (Nault, 1980). Testes preliminares indicaram que a infecção por $S$. kunkelii induz estrias cloróticas no híbrido XL 330 em casa de vegetação (dados não publicados). A presença do espiroplasma em plantas com estrias cloróticas foi confirmada pelo teste PTA-ELISA 
("plate-trapped antigen enzyme-linked immunosorbant assay") (Mowat \& Dawson, 1987) com antissoro policlonal para S. kunkelii, utilizando-se a fosfatase alcalina como enzima e o fosfato de nitro-fenil como substrato. $\mathrm{O}$ antissoro foi gentilmente cedido pelo Dr. Donald Gordon (Ohio State University, Wooster, OH, USA).

Para se detectar infecções por fitoplasma, amostras de folhas das plantas-teste com sintomas de enfezamento ou descoloração de folhas (com ou sem estrias cloróticas) foram coletadas após 50-60 dias do PAI, e submetidas ao teste de PCR (Polimerase Chain Reaction). A extração e amplificação de DNA das amostras foram conduzidas conforme descrito por Lee et al. (1995), utilizando-se os primers R16F2N (5'-ACG ACT GCT AAG ACT GG-3') e R16R2 (5'-TGA CGG GCG GTG TGT ACA AAC CCC G$3 ')$, que amplificam o gene $16 \mathrm{~S}$ do rDNA de fitoplasmas.

Pelo fato dos espécimes terem sido testados em grupos sobre as plantas-teste, a taxa individual de infectividade das cigarrinhas para os dois molicutes foi estimada com base na fórmula proposta por Swallow (1985), I = 1-(1-p $)^{1 / k}$, sendo $p$ a proporção de plantas infectadas no bioensaio de transmissão e $k$ o número de cigarrinhas confinadas por planta-teste.

\subsection{RESULTADOS E DISCUSSÃO}

Adultos de $D$. maidis foram observados e coletados em milho em todos os talhões experimentais, inclusive nas áreas (III, IV e V) onde não se cultivava milho. Foram realizados 11 bioensaios de transmissão com um total de 797 cigarrinhas coletadas e 158 plantas-teste avaliadas (Tabela 8). Estrias cloróticas diagnósticas de $S$. kunkelii (Nault, 1980) puderam ser observadas em 97,5\% de um total de 40 plantas com sintomas de enfezamento nos bioensaios de transmissão, aos 50-60 dias após o PAI. A análise por PCR de todas as plantas sintomáticas (enfezamentos pálido ou vermelho), revelou que apenas $12,5 \%(n=5)$ estavam infectadas com fitoplasma, sendo que $10 \%$ $(n=4)$ apresentaram infecção pelos dois molicutes. 
Tabela 8. Estimativas de infectividade natural por Spiroplasma kunkelii e fitoplasma em adultos de Dalbulus maidis amostrados na região de Anastácio/MS, em diferentes áreas e fases da cultura do milho, na safra 1997/98 e 1998/99.

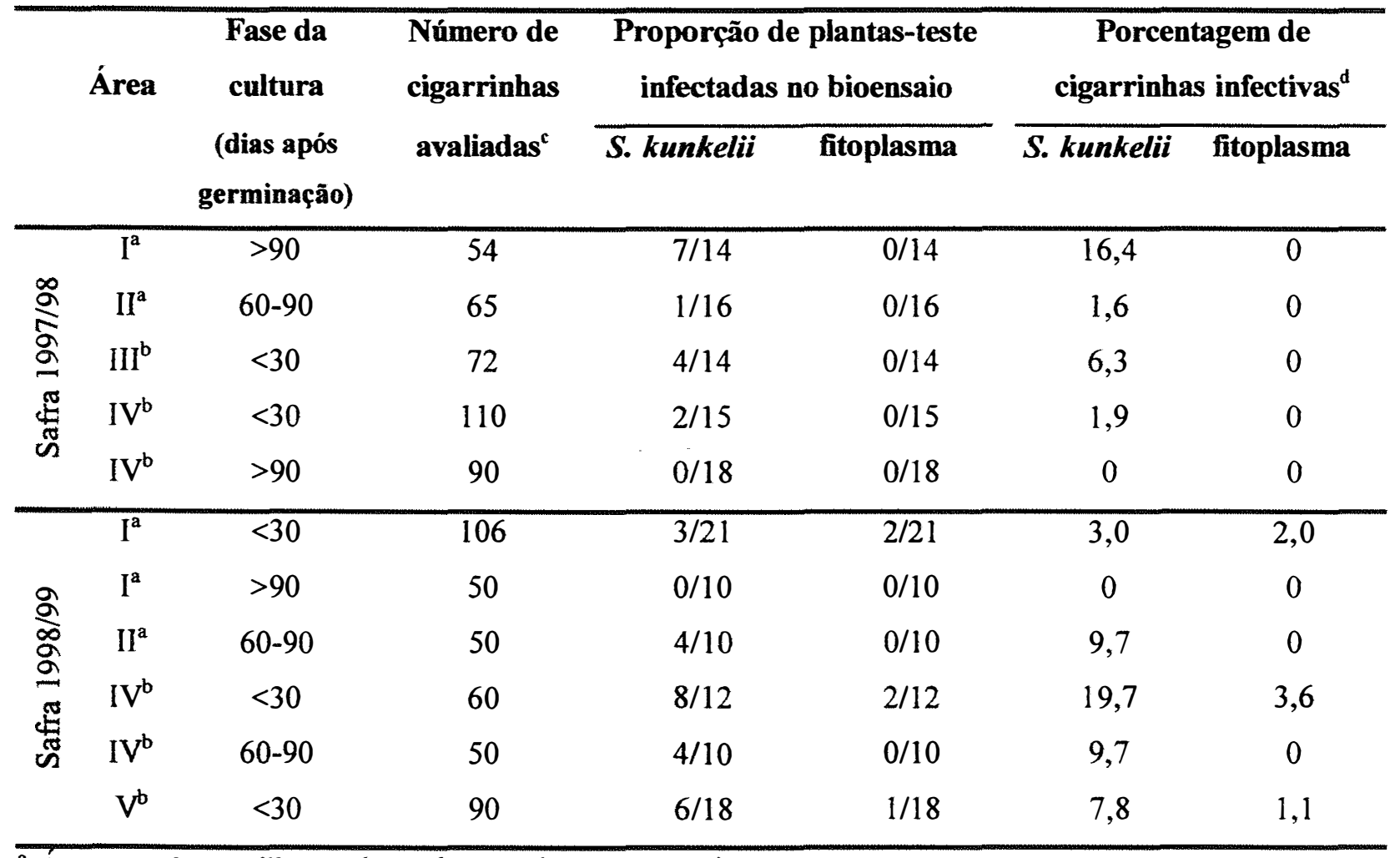

${ }^{a}$ Áreas onde o milho é plantado anualmente na primavera;

b Áreas de pastagens perenes onde não se cultivava milho há pelo menos 5 anos;

${ }^{\mathrm{c}}$ Espécimes foram avaliados em grupos de 4-7 por planta-teste, dependendo do bioensaio;

d Estimativa da \% de espécimes infectivos baseando-se na fórmula de Swallow (1985), $\mathrm{I}=1-(1-p)^{1 / k}$, sendo $p$ a proporção de plantas infectadas no bioensaio de transmissão e $k$ o número de cigarrinhas confinadas por planta-teste.

A porcentagem de cigarninhas infectivas ( $S$. kunkelii e/ou fitoplasma) nas diferentes áreas avaliadas e nas duas safras variou de 1,1 a 19,7\% (Tabela 8). Na safra 1997/98, a porcentagem de cigarrinhas infectivas com $S$. kunkelii variou de 1,6 a 16,4\%, não se detectando nenhum espécime infectivo com fitoplasma. Na safra 1998/99, a porcentagem de espécimes de $D$. maidis infectivos com espiroplasma ficou entre 3,0 a 19,7\%; para fitoplasma esta porcentagem variou de 1,1 a 3,6\%. As freqüências de 
espécimes positivos para $S$. kunkelii foram maiores do que para fitoplasma em todas as áreas.

As cigarrinhas imigrantes, coletadas logo após a germinação do milho ( $<30$ dias), mostraram taxas relativamente altas de infectividade por S. kunkelii nas safras 1997/98 $(1,9-6,3 \%)$ e 1998/99 (3,0 - 19,7\%), mesmo em áreas de pastagens perenes (III, IV e V), onde o milho não havia sido cultivado há pelo menos 5 anos. A área IV, que anteriormente era pastagem, apresentou uma porcentagem elevada $(19,7 \%)$ de espécimes infectivos por $S$. kunkelii, e relativamente alta para fitoplasma (3,6\%) na safra 1998/99, o que talvez tenha sido devido ao fato de que nesta área o milho passou a ser plantado de forma escalonada a partir de 1997/98, aumentando, assim, a quantidade de inóculo.

Estudos conduzidos nas Américas do Norte e Central têm indicado que tanto $D$. maidis como os molicutes, $S$. kunkelii e fitoplasma, apresentam uma gama restrita de plantas hospedeiras naturais para reprodução, constituída basicamente de milho e teosintos (Barnes, 1954; Larsen et al., 1992; Nault, 1980), embora já tenha sido relatada a criação de D. maidis em Tripsacum dactyloides (L.) (Pitre et al., 1966), bem como a transmissão experimental de $S$. kunkelii para algumas dicotiledôneas (Markham et al., 1977). Assim, pouco se sabe a respeito de como D. maidis e esses molicutes sobrevivem na entressafra do milho, em regiões onde teosintos não ocorrem ou são raros. Esta cigarrinha que é abundante durante a cultura do milho, desaparece dos campos após sua seca. Nault (1990) e Larsen et al. (1992) sugerem como possíveis estratégias para esta espécie no México, a sobrevivência em plantios de milho irrigado ou em hábitats adjacentes aos campos de milho, ou a hibernação de adultos nos restos culturais ou vegetação próxima de plantios. Alternativamente, a migração e dispersão parecem ser estratégias importantes para a sobrevivência de insetos que utilizam hospedeiros de ciclo curto como o milho. Em países como o México e Guatemala, adultos de D. maidis podem ser encontrados em todas as espécies de teosintos amostradas, inclusive em plantas perenes do gênero Tripsacum L. (Nault \& DeLong, 1980). No entanto, somente depois que os campos de milho maturam e suas folhas secam é que as cigarrinhas procuram as folhas verdes de Tripsacum spp. (Nault, 1990). No Brasil, as condições para sobrevivência da cigarninha-do-milho na entressafra parecem ser mais drásticas, pelo 
menos com relação a hospedeiros alternativos, pois plantas como teosintos e Tripsacum são muito pouco comuns. Assim, na ausência de outras plantas hospedeiras, D. maidis estaria em completa dependência de seu hospedeiro primário, o milho, podendo utilizar a migração ou dispersão para a localização de novos cultivos ao final de cada safra.

A região de Anastácio/MS tem como característica a presença de um extenso contínuo de pastagens perenes com cultivo do milho apenas em pequenas áreas de subsistência, sendo que áreas de cultivo intensivo de milho estão distantes mais de 50 $\mathrm{km}$, e a entressafra estende-se por cerca de 6-7 meses. Especulamos, portanto, que as cigarrinhas que primeiro chegam às áreas de pastagens perenes, advém, por meio de migração, de locais distantes. Esta hipótese vem sendo sustentada por estudos populacionais e genéticos de D. maidis conduzidos nesta mesma região (Capítulos $1 \mathrm{e}$ 2). Por exemplo, nenhum espécime de D. maidis foi coletado nas áreas de pastagens perenes (III, IV e V) em vegetação adjacente aos talhões experimentais, especialmente gramineas, com uso de rede de varredura, antes do plantio do milho. Esta hipótese de migração é congruente com estudos realizados por Taylor et al (1993) que, avaliando a atividade de vôo de $D$. maidis em diferentes temperaturas de criação, luminosidade e condição de planta hospedeira, sugeriram um possivel comportamento migratório para esta espécie. Estudos de comportamento de fuga de D. maidis em laboratório demonstraram a sua pronta aptidão para o vôo (Heady \& Nault, 1985), que é particularmente importante para espécies que utilizam hospedeiros sazonais, onde pequenos vôos poderiam levá-los para culturas próximas (Nault, 1990).

A coleta de cigarrinhas infectadas com S. kunkelii e fitoplasma nas áreas de pastagens perenes (III, IV e V), logo após a germinação do milho, sugere que os molicutes foram transportados na entressafra por espécimes migratórios de D. maidis, possivelmente oriundos de áreas distantes. Os dados também reforçam a hipótese de que S. kunkelii pode sobreviver no vetor na ausência da planta hospedeira, durante períodos de entressafra (Ebbert \& Nault, 1994).

A relação entre D. maidis e os molicutes, $S$. kunkelii e fitoplasma, é do tipo persistente e propagativa, ou seja uma vez tendo adquirido o patógeno este multiplica-se no vetor, permanecendo este último infectivo durante toda a vida (Nault, 1997). Neste 
tipo de relação, os vetores, e não as plantas, parecem estar mais bem adaptados como hospedeiros para estes patógenos, sendo raros os casos em que patógenos propagativos causam efeitos adversos em seus vetores (Nault, 1997). Uma longa associação entre um vetor e um patógeno de planta geralmente evolui para compatibilidade, onde o patógeno é pouco ou não patogênico ao vetor (Madden $\&$ Nault, 1983). Observou-se neste estudo que em praticamente todas as áreas e épocas avaliadas infecções por $S$. kunkelii em $D$. maidis foram maiores que por fitoplasma. Madden et al. (1984) mostraram que $S$. kunkelii não é patogênico à cigarrinha-do-milho, não afetando a longevidade ou fecundidade de adultos em temperaturas entre 20 e $29^{\circ} \mathrm{C}$, enquanto que o MBSP afetou significativamente estes parâmetros biológicos do vetor. Além disso, Ebbert \& Nault (1994) observaram que infecções por $S$. kunkelii propiciam alguns benefícios a $D$. maidis, como por exemplo, o aumento da sobrevivência, principalmente de fềmeas, em temperaturas entre 10 e $20^{\circ} \mathrm{C}$, que chegou a ser de 2,2 vezes, comparando-se com espécimes sadios. Isto pode ser particularmente importante na estratégia de sobrevivência dessa cigarrinha e do espiroplasma, na entressafra do milho. Portanto, a maior freqüência de espécimes de D. maidis infectados por $S$. kunkelli do que por fitoplasma nas áreas estudadas pode estar associada à relação de mútuo benefício existente entre o espiroplasma e o vetor.

Os resultados deste estudo são relevantes para se delinear estratégias de manejo visando minimizar os prejuízos causados por esses molicutes em milho na América Latina, uma vez que as primeiras cigarrinhas colonizando a cultura podem trazer consigo quantidades relativamente altas de inóculo, mesmo após um período de pousio de vários meses. Para melhor compreender os mecanismos de sobrevivência e disseminação dos molicutes na entressafra do milho, são necessários estudos mais abrangentes da gama de hospedeiros alternativos desses patógenos e do vetor, $D$. maidis. 


\section{CONCLUSÕES}

- Dalbulus maidis (DeLong \& Wolcott) coloniza o milho logo após sua germinação na região de Anastácio/MS, mesmo em áreas onde esse cereal não é plantado há muitos anos.

- Adultos da cigarrinha-do-milho são capturados por cartões adesivos amarelos em áreas com o solo preparado para o plantio, antes mesmo da germinação da cultura.

- Picos de captura de D. maidis ocorrem também durante a entressafra do milho, simultaneamente em áreas isoladas, sendo maiores em locais de solo descoberto por aração e/ou gradagem.

- Em áreas onde o milho é plantado estacionalmente, a proporção de fềmeas é maior entre os indivíduos coletados nos picos de entressafra ou no início e final da cultura, do que no meio da safra do milho.

- Adultos da cigarrinha-do-milho são capturados em vôo em alturas superiores a $13 \mathrm{~m}$.

- Rebrotas de milho favorecem a manutenção de populações da cigarrinha-domilho na entressafra. 
- A técnica de RAPD-PCR é uma ferramenta útil para análise da estrutura genética de populações de $D$. maidis.

- Populações de D. maidis coletadas em Anastácio/MS em diferentes áreas em uma mesma safra são geneticamente semelhantes.

- A população de D. maidis coletada em Mossoró/RN é geneticamente isolada das populações coletadas na região Centro-Sul do Brasil.

- Dos métodos testados para a conservação do DNA de D. maidis para uso em RAPD-PCR, o congelamento a $-20^{\circ} \mathrm{C}$ foi o mais adequado.

- Os métodos álcool etilico absoluto e $70 \%\left(-20^{\circ} \mathrm{C}\right)$ e tampão de extração (inseto inteiro e macerado) preservam satisfatoriamente o DNA de D. maidis.

- Os métodos álcool etilico absoluto e $70 \%$ (temperatura ambiente) e secagem ao ar preservam o DNA de D. maidis por 120,60 e 10 dias, respectivamente.

- Uma porcentagem significativa de imigrantes de D. maidis que colonizam plantios de milho em Anastácio/MS encontra-se com Spiroplasma kunkelii Whitcomb et al. ou fitoplasma do milho, sendo mais freqüentes as infecções pelo primeiro patógeno. 


\section{REFERÊNCIAS BIBLIOGRÁFICAS}

ALJANABI, S. M.; LOIÁCONO, M. S.; LOURENÇO, R. T.; BORGES, M.; TIGANO,

M. S. RAPD analysis revealing polymorfism in egg parasitoids of soybean stink bugs (Hemiptera: Pentatomidae). Anais da Sociedade Entomológica do Brasil, v. 27, n. 3, p. 413-420, 1998.

ALMEIDA, T. C. Utilização do milho e do sorgo no Brasil. In: BÜLL, L. T. ; CANTARELlA, H. (Ed.) Cultura do milho - fatores que afetam a produtividade. Associação Brasileira para pesquisa da potassa e do fosfato, Piracicaba: POTAFÓS, 1993. cap. 2, p. 11-21.

ALSTATT, G. E. A new corn disease in the Rio Grande Valley. Plant Disease Reporter, v. 29, n. 20, p. 533-534, 1945.

ANUÁRIO ESTATÍSTICO DO BRASIL-1979, v. 39, p. 362, 1979.

AUDISIO, P.; DE BIASE, A.; ROMANELLI, P.; ANGELICI, M. C.; KETMAIER, V.; DE MATTHAEIS, E. Molecular re-examination of the taxonomy of the Meligethes viridescens species complex (Coleoptera: Nitidulidae). Biochemical. Systematics and Ecology, v. 28, n. 1, p. 1-13, 2000. 
AUSTIN, A. D.; DILLON, N. Extraction and PCR of DNA from parasitoid wasps that have been chemically dried. Australian Journal of Entomology, v. 36, n. 3, p. 241-244, 1997.

AVISE, J. C. Molecular markers, natural history and evolution. New York: Chapman \& Hall, 1994. 511p.

BACKUS, E. A. Anatomical and sensory mechanisms of leafhopper and planthopper feedin behavior. In: Nault, L. R.; Rodriguez, J. G (Ed.), The leafhoppers and planthoppers. New York: John Wiley, 1985. p. 163-194.

BARNES, D. Biologia, ecologia, y distribucion de las chicharritas, Dalbulus elimatus (Ball) y Dalbulus maidis (Del. \& W.). Mexico: Secretaria de Agricultura y Ganaderia, Oficina de Estudios Especiales, 1954. 112 p. (Folleto Tecnico, 11).

BARUFFI, L.; DAMIANI, G.; GUGLIELMINO, C. R.; BANDIS, C.; MALACRIDA, A. R.; GASPERI, G. Polymorphism within and between populations of Ceratitis capitata: comparison between RAPD and multilocus enzyme eletrophoresis data. Heredity, v. 74, n. 4, p. 425-437, 1995.

BLACK, W. C. IV; DUTEAU, N. M.; PUTERKA, G. J.; NECHOLS, J. R.; PETTORINI, J. M. Use of the randon amplified polymorphic DNA polimerase chain reaction (RAPD-PCR) to detect DNA polymorphisms in aphids (Homoptera: Aphididae). Bulletin of Entomological Research, v. 82, n. 2, p. 151-159, 1992.

BLACKMER, J. L.; BYRNE, D. N. Environmental and physiological factors influencing phototactic flight of Bemisia tabaci. Physiological Entomology, v. 18, n. 4, p. 336-342, 1993.

BRADFUTE, O. E.; TSAI, J. H.; GORDON, D. T. Spiroplasma and viruses association with maize epidemic in southem Florida. Plant Disease, v. 65, n. 10, p. 837-841, 1981. 
BRAMWELL, N. H.; BURNS, B. F. The effects of fixative type and fixation time on the quantity and quality of extractable DNA for hybridization studies on lymphoid tissue. Experimental Hematology, v. 16, p. 730-732, 1988.

BUSHING, R. W.; BURTON, V. E. Leafhoppers damage to silage corn in California. Journal of Economic Entomology, v. 67, n. 5, p. 656-658, 1974.

CARLSON, J. D.; WHALON, M. E.; LANDIS, D. A.; GAGE, S. H. Springtime weather patters coincident with long-distance migration of potato leafhopper into Michigan. Agricultural and Forest Meteorology, v. 59, n. 3-4, p. 183-206, 1992.

CARLSON, J. E.; TULSIERAM, L. K.; GLAUBITZ, J.C.; LUK, V. W. K.; KAUFFELDT, C.; RUTLEDGE, R. Segregation of random amplified DNA markers in FI progeny of conifers. Theoretical and Applied Genetics, v. 83, n. 2, p. 194-200, 1991.

CENIS J. L.; PEREZ, P.; FERERES, A. Identification of aphid (Homoptera: Aphididade) species and clones by random amplified polymorphic DNA. Annals of the Entomological Society of America, v. 85, n. 5, p. 545-550, 1993.

CENIS, J. L.; BEITIA, F. Aplicacion de la tecnica RAPD-PCR (ADN polimorfico amplificado al azar) a la identificacion de insectos. Investigacion Agraria: Produccion y Proteccion Vegetales, v. 9, n. 2, p. 289-297, 1994.

CESARONE, C. F.; BOLOGNESI, C.; SANTI, L. Improved microfluorometric DNA determination in biological material using Hoescht 33258. Analytical Biochemistry, v. 100, n. 1, p. 188-197, 1979.

CHAN, C. K.; PETERSEN, D. J.; VRAIN, T. C. DNA fingerprinting of single aphid embryos by random amplified polymorphic DNA polymerase chain reaction (RAPD-PCR). The Canadian Entomologist, v. 131, n. 2, p. 229-230, 1999. 
COSTA, A. S. Alguns insetos e ácaros usados na transmissão de moléstias de vírus das plantas. Bragantia, v. 16, p. XV-XXI, 1957.

D'ARCY, C. J.; NAULT, L. R. Insect transmission of plant viruses and mycoplasmalike and rickettsialike organisms. Plant Disease, v. 66, n. 2, p. 99-104, 1982.

DAVID, C. T.; HARDIE, J. The visual responses of free-flying summer and autumn forms of the black bean aphid, Aphis fabae, in an automated flight chamber. Physiological Entomology, v. 13, n. 3, p. 277-284, 1988.

DAVIS, R. E.; WORLEY, J. F.; WHITCOMB, R. F.; ISHIMA, T.; STEERE, R. L. Helicidal filaments produced by a micoplasma-like organism associated with corn stunt disease. Science, v. 176, n. 4034, p. 521-523, 1972.

DECKER, G. C.; CUNNINGHAM, H. B. The mortality rate of the potato leafhopper and some related species when subjected to prolonged exposure at various temperatures. Journal of Economic Entomology, v. 60, n. 2, p. 373-379, 1967.

DeLONG, D. M.; CALDWELL, J. S. Hibernation studies of the potato leafhopper (Empoasca fabae Harris) and related species of Empoasca occurring in Ohio. Journal of Economic Entomology, v. 28, n. 2, p. 442-444, 1935.

DENLINGER, D. L. Dormancy in tropical insects. Annual Review of Entomology, v. 31, p.239-264, 1986.

DENNO, R. F. Fitness, population dynamics and migration in planthoppers: the role of hosts plants. In: RANKIN, M. A. (Ed.) Migration: mechanisms and adptative significance. Port Aransas: Marine Science Institute, 1985. p. 623-640. 
DENNO, R. F.; RAUPP, M. J; TALLAMY, D. W.; REICHELDERFER, C. F. Migration in heterogeneous environments: differences in habitat selection between the wing forms of the dimorphic planthopper, Prokelisia marginata (Homoptera: Delphacidae). Ecology, v. 61, n. 4, p. 859-867, 1980.

DENNO, R. F.; RODERICK, G. K.; OLMSTEAD, K. L.; DÖBEL, H. G. Densityrelated migration in planthoppers (homoptera: Delphacidae): the role of habitat persistence. The American Naturalist, v. 138, n. 6, p. 1513-1541, 1991.

DENNO, R. F.; RODERICKG. K. Population biology of planthopper. Annual Review of Entomology, v. 35, p. 489-520, 1990.

DESSAUER, H. C.; COLE, C. J.; HAFNER, M. S. Colletion and storage of tissues. In: HILLIS, D. M.; MORTIS, C.; MABLE, B. K. (Ed.) Molecular Systematics. Sunderland: Sinauer, 1996. p.29-47.

DeVERNO, L. L.; SMITH, G. A.; HARRISON, K. J. Randomly Amplified Polymorphic DNA evidence of introgression in two closely related sympatric species of coniferophagous Choristoneura (Lepidoptera: Tortricidae) in Atlantic Canada. Annals of the Entomological Society of America, v. 91, n. 3, p. 248-259, 1998.

DIETRICH, C. H.; FITZGERALD, S. J.; HOLMES, J. L.; BLACK IV, W. C.; NAULT, L. R. Reassessment of Dalbulus leafhopper (Homoptera: Cicadellidae) phylogeny based on mitocondrial DNA sequences. Annals of the Entomological Society of America, v. 91, n. 5, p. 590-597, 1998.

DILLON, N.; AUSTIN, A. D.; BARTOWSKY, E. Comparison of preservation techniques for DNA extration from hymenopterous insects. Insect Molecular Biology, v. 5, n. 1, p. 21-24, 1996.

DINGLE, H. Migrations strategies of insects. Science, v. 175, n. 4028, p. 1327-1335, 1972. 
DINGLE, H. Ecology and evolution of migration. In: GAUTHREAUX JR., S. A. (Ed.) Animal migration, orientation, and navigation. New York: Academic Press, 1980. p.1-101.

DINGLE, $H$. Function of migration in the seasonal syncronization of insects. Entomologia Experimentalis et Appicata, v. 31, n. 1, p. 36-48, 1982.

DINGLE, H. Migration and life histories. In: RANKIN, M. A. (Ed.) Migration: mechanisms and adptative significance. Port Aransas: Marine Science Institute, 1985a. p. $27-42$.

DINGLE, H. Insect migration In: RANKIN, M. A. (Ed.) Migration: mechanisms and adptative significance. Port Aransas: Marine Science Institute, 1985b. p. 619621.

DIXON, A. F. G. Fecundity of brachypterous and macropterous alatae in Drepanosiphum dixoni (Callaphididae, Aphididae). Entomologia Experimentalis et Applicata, v. 15, n. 3, p. 335-340, 1972.

DIXON, A. F. G.; HOWARD, M. T. Dispersal in aphids, a problem in resource allocation. In: DANTHANARAYANA, W. (Ed.) Insect flight: dispersal and migration. Berlin: Spring-Verlag, 1986. cap. 10, p. 145-151.

DRAKE, V. A. Collective orientation by nocturnally migrating Australian plague locust, Chortoicetes terminifera (Walker) (Orthoptera: Acrididae): a radar study. Bulletin of Entomological Research, v. 73, n. 4, p. 679-692, 1983.

DRAKE, V. A.; FARROW, R. A. The influence of atmospheric structure and motions of insect migration. Annual Review of Entomology, v. 33, p. 183-210, 1988.

DREISIG, $\mathrm{H}$. The importance of illumination level in daily onset of flight activity in nocturnal moths. Physiological Entomology, v. 5, n. 4, p. 327-342, 1980. 
DRY, W. W.; TAYLOR, L. R. Light and temperature thresholds for take-off by aphids. Journal of Animal Ecology, v. 39, p. 493-504, 1970.

EBBERT, A. M.; NAULT, L. R.. Improved overwintering ability in Dalbulus maidis (Homoptera: Cicadellidae) vector infected with Spiroplasma kunkelii (Mycoplasmatales: Spiroplasmatacea). Environmental Entomology, v. 23, n. 3, p. 634-644, 1994.

FANCELLI, A. L. Influência do desfolhamento no desempenho de plantas e de sementes de milho (Zea moys L.). Piracicaba, 1988. 172 p. Tese (Doutorado) Escola Superior de Agricultura "Luiz de Queiroz", Universidade de São Paulo.

FANCELli, A. L.; NETO, D. D. 2000. Produção de milho. Guaiba: Agropecuária, 2000. 360p.

FERNANDES, F. T.; BALMER, E. Situação das doenças de milho no Brasil. Informe Agropecuário, v. 14, n. 165, p. 35-37, 1990.

FERREIRA, E. F.; GRATTAPAGLIA, D. Introdução ao uso de marcadores moleculares em análise genética. 2.ed. Brasília: EMBRAPA-CENARGEM, 1996. $220 \mathrm{p}$.

FLINN, P. W.; HOWER, A. A.; TAYLOR, R. A. J. Immigration, sex ratio, and local movement of the potato leafhopper (Homoptera: Cicadellidae) in a Pennsylvania alfafa field. Journal of Economic Entomology, v. 83, n. 5, p. 1858-1862, 1990.

FNP CONSULTORIA \& COMÉRCIO. Agrianual 2000: anuário de agricultura brasileira. São Paulo, 2000. 546p. 
FOLEGATTI, M. E. G.; LOPES, J. R. S.; AMORIN, L.; SILVA, W. J.; SOLFERINO, O. B.; SILVA, H. P.; PEREIRA, O. A. P. Incidência de enfezamento do milho e população do vetor, Dalbulus maidis em diferentes localidades e épocas de plantio, na safra 95/96. In: CONGRESSO BRASILEIRO DE FITOPATOLOGIA, 30, Poços de Caldas, 1997. Resumos. Fitopatologia Brasileira, v. 22, ago., 1997. p. 347. Supl.

GÁMEZ, R.. Maize rayado fino disease: the virus. In: GORDON, D. T.; KNOKE, K. J.; NAULT, R. L.; RITTER, R. M. (Ed.) Proccedings, international mayze virus disease colloquium and workshop, Aug. 2-6, 1982. The Ohio State Universite, Wooster, 1983. p. 62-68.

GÁMEZ, R.; LEÓN, P. Ecology and evolution of a neotropical leafhoppers virus-maize association. In: NAULT, L. R. ; RODRIGUEZ, J. G. (Ed.) The leafhoppers and planthoppers. New York: John Wiley, 1985. p. 331-350.

GARCIA, J. C. Evolução da área e produtividade do milho "safrinha" por estado. In: SEMINÁRIO SOBRE A CULTURA DO MILHO "SAFRINHA", 4, Assis, 1997. Anais. Assis: IAC/CDV, 1997. p. 11-14.

GATEHOUSE, A. G. Behavior and ecological genetics of wind-borne migration by insects. Annual Review of Entomology, v. 42, p. 475-502, 1997.

GLADSTONE, S. M.; LA LLANA, A.; RIOS, R. ; LOPEZ, L. Egg parasitoids of the com leafhopper, Dalbulus maidis (DeLong; wolcott) (Homoptera: Cicadellidae) in nicaraguan maize. Proceedings of the Entomological Society of Washington, $v$. 96, n. 1, p., 143-146, 1994.

GOELZ, S. E.; HAMILTON, S. R.; VOGELSTEIN, B. Purification of DNA from formaldehyde fixed and paraffin embedded human tissue. Biochemical and Biophysical Research Communications, v. 130, n. 1, p. 118-126, 1985. 
GORDON, D. T.; NAULT, L. R.; GORDON, N. H. ; HEADY, S. E. Serological detection of com stunt spiroplasma and maize rayado fino virus in field collected Dalbulus spp. from Mexico. Plant Disease, v. 69, n. 2, p. 108-111, 1985.

GORDON, D. T.; KNOKE, J. K.; SCOTT, G. E. Virus and viruslike diseases of maize in the United State. Wooster, Ohio: Ohio Agricultural Research and Development Center, 1981.210p.

GRODZICKER, T.; WILLIANS, J.; SHARP, P.; SAMBROOK, J. Physical mapping of temperature-sensitive mutations of adenovirus. Cold Spring Harbor Symposia on Quantitative Biology, v. 39, p. 439-446, 1974.

GUIRAO, P.; BEITIA, F.; CENIS, J. L. Biotype determination of Spanish populations of Bemisia tabaci (Hemiptera: Aleyrodidae). Bulletin of Entomological Research, v. 87, n. 6, p. $587-593,1997$.

GUNN, A.; GATEHOUSE, A. G. The migration syndrome in the african armyworm moth, Spodoptera exempta: allocation of resources to flight and reproduction. Physiological Entomology, v. 18, n. 2, p. 149-159, 1993.

HALGREN, L. A.; TAYLOR, L. R. Factors affecting flight responses of alienicolae of Aphis fabae Scop. and Schizaphis graminum Rondani (Homoptera: Aphididae). Journal of Animal Ecology, v. 32, p. 583-593, 1968.

HARDIE, J. Spectral specificity for targeted flight in the black bean aphid Aphis fabae. Journal of Insect Physiology, v. 35, n. 8, p. 619-626, 1989.

HARRISON, R. G. Dispersal polymorphisms in insects. Annual Review of Ecology and Systematics, v. 11, p. 95-118, 1980.

HAYMER, D. S. Arbitrary (RAPD) primer sequences used in insect studies. Insect Molecular Biology, v. 3, n. 3, p. 191-194, 1994. 
HAYMER, D. S.; McINNIS, D. O. Resolution of populations of the Mediterraean fruit fly at the DNA level using random primers for the polymerase chain reaction. Genome, v. 37, n. 2, p. 244-248, 1994.

HAYMER, D. S.; MEI, H.; McINNIS, D. O. Genetic marker analysis of spatial and temporal relationships among existing populations and new infestations of the mediterranean fruit fly (Ceratitis capitata). Heredity, v. 79, n. 3, p. 302-309, 1997.

HEADY, S. E.; NAULT, L. R. Escape behavior of Dalbulus and Baldulus leafhoppers (Homoptera: Cicadellidae). Environmental. Entomology, v. 14, n. 2, p. 154-158, 1985.

HODGE, K. T.; SAWYER, A. J.; HUMBER, R. A. RAPD-PCR for identification of Zoophthora radicans isolates in biological control of the potato leafhopper. Journal of Invertebrate Pathology, v. 65, n. 1, p. 1-9, 1995.

HOGG, D. B. Potato leafhopper (Homoptera: Cicadellidae) inmature development, life tables and populations dynamics under fluctuating temperature regimes. Environmental Entomology, v., 14, n. 3, p. 249-355, 1985.

HOLT, J.; CHANCELlOR, T. C. B.; REYNOLDS, D. R.; TIONGCO, E. R. Risk assessment for rice planthopper and tungro disease outbreaks. Crop Protection, v. 15, n. 4 , p. $359-368,1996$.

HOOLE J. C.; JOICE, D. A.; PULliN, A. S. Estimates of gene flow between populations of the swallowtail butterfly, Papilio machaon in Broadland, UK and implications for conservations. Biological Conservation, v. 89, n. 3, p. 293-299, 1999.

HOUDE, P.; BRAUN, M. J. Museum collections as a source of DNA for studies of avian phylogeny. AUK: A Journal of Ornithology, v. 105, n. 4, p. 773-736, 1988. 
HOY, C. W.; HEADY, S. E.; KOCH; T. A. Species composition, phenology, and possible origins of leafhoppers (Cicadellidae) in Ohio vegetable crops. Journal of Economic Entomology, v. 85, n. 6, p. 2336-2343, 1992.

HUNT, E. R.; NAULT, L. R. Roles of interplant movement, acoustic communication, and phototaxis in mate-location behavior of the leafhopper Graminella nigrifrons. Behavioral Ecology and Sociobiology, v. 28, n. 5, p. 315-320, 1991.

HUNT, G. J.; PAGE, R. E. JR. Linkage map of honey bee, Apis mellifera, based on RAPD markers. Genetics, v. 139, n. 3, p. 1371-1382, 1995.

INFANTE-MALACHIAS, M. E., YOTOKO, K. S. C.; AZEREDO SPIN, A. M. L. Random amplified popymorphic DNA of screwworm fly populations (Diptera: Calliphoridae) from Southeastern Brazil and Northern Argentina. Genome, v. 42, n. 4, p. 772-779, 1999.

JOHNSON, C. G. Physiological factors in insect migration by flight. Nature, v. 198, n. 4879, p. 423-427, 1963.

JOHNSON, C. G. Migration and dispersal of insects by flight. London: Methuen, 1969. $763 \mathrm{p}$.

KENNEDY, J. S. A tuming point in the study of insect migration. Nature, v. 189, n. 4767, p. 785-791, 1961.

KENNEDY, J. S. Migration, behavioral and ecological. In: RANKIN, M. A. (Ed.) Migration: mechanisms and adptative significance. Port Aransas: Marine Science Institute, 1985. p. 5-26.

KENNEDY, J. S.; BOOTH, C. O.; KERSHAW, W. J. S. Host finding by aphids in the field. III. Visual atraction. Annals of Applied Biology, v. 49, n. 1, p. 1-21, 1961. 
KISIMOTO, R.; SOGAWA, K. Migration of the brown planthopper Nilapavarta lugens and white-backed planthopper Sogatella furcifera in East Asian: the role of weather and climate. In: DRAKE, V. A.; GATEHOUSE, A. G. (Ed.) Insect migration. Cambridge: University Press, 1995. p.67-92.

KITAJIMA, E. W.; NAZARENO, N. R. X. Levantamento de virus e Mollicutes do milho, no Estado do Paraná. Fitopatologia Brasileira, v. 10, n. 3, p. 613-625, 1985.

KITAJIMA, E. W.; RIBEIRO, R. L. D.; LIN, M. T.; RIBEIRO, M. I. S. D.; KIMURA, O.; COSTA, C. L.; PIMENTEL, J. P. Lista comentada de vírus e organismos do tipo micoplasma em plantas cultivadas e silvestres do Estado do Rio de Janeiro. Fitopatologia Brasileira, v. 9, n. 3, p. 607-625, 1984.

KOLLER, B.; LEHMANN, A.; McDERMOTT, J. M.; GESSLER, C. Identification of apple cultivars using RAPD markers. Theoretical and Applied Genetics, v. 85, n. 6-7, p. 901-904, 1993.

LANDRY, B. S.; DEXTRAZE, L.; BOIVIN, G. Random amplified polymorphic DNA markers for DNA fingerprinting and genetic variability assessment of minute parasitic wasp species (Hymenoptera: Mymaridae and Trichogrammatidae) used in biological control programs of phytophaguos insects. Genome, v. 36, n. 3, p. 580$587,1993$.

LARSEN, K. J.; NAULT, L. R. ; MOYA-RAYAGOSA, G. Overwintering biology of Dalbulus leafhoppers (Homoptera: Cicadellidae): adult population and drought hardiness. Environmental Entomology, v. 21, n. 3, p. 566-577, 1992.

LARSEN, K. J.; NAULT, L. R. Seasonal polymorphism of adult Dalbulus maidis (Homoptera: Cicadellidae). Annals of the Entomological Society of America, v. 87, n. 3, p. 356-362, 1994. 
LARSEN, K. J.; MADDEN, V. L. ; NAULT, L. R. Effect of temperature and host plant on the development of the blackfaced leafhopper. Entomologia Experimentalis et Applicata, v. 55, n. 3, p. 285-294, 1990.

LAURENT V.; WAJNBERG, E.; MANGIN, B.; SCHIEX, T.; GASPIN, C.; VANLERBERGHE-MASUTTI, F. A composite genetic map of the parasitoid wasp Trichogramma brassicae based on R APD markers. Genetics, v. 150, n. 1, p. 275-282, 1998.

LEE, I. M; BERTACCINI, A; VIBIO, M; GUNDERSEN, D. E. Detection of multiple phytoplasmas in perennial fruit trees with decline symptoms in Italy. Phytopathology, v. 85, n. 6, n. 728-735, 1995.

LIN, H.; DOWNE, D. A.; WALKER, M. A.; GRANETT, J.; ENGLISH-LOEB, G. Genetic structure in native populations of grape phylloxera (Homoptera: Phylloxeridae). Annals of the Entomological Society of America, v. 92, n. 3, p. 376-381, 1999.

LINGREN, P. D.; RAULSTON, J. R.; POPHAM, T. W.; WOLF, W. W.; LINGREN, P.S.; ESQUIVEL, J. F. Flight behaviour of corn-earworm (Lepidoptera, Noctuidae) moths under low wind-speed conditions. Environmental Entomology, v.24, n. 4, p. 851-860, 1995.

LOGAN, J. A. Extraction, polymerase chain reaction, and sequencing of a 440 base pair region of the mitocondrial cytochrome oxidase I gene from two species of acetonepreserved damselflies (Odonata: Coenagrionidae, Agrionidae). Environmental Entomology, v. 28, n. 2, p. 143-147, 1999.

LOU, K. F.; WEISS, M. J.; BRUCKNER, P. L.; MORRILL, W. L.; TALBERT, L. E.; MARTIN, J. M. RAPD variation within and among geografic populations of wheat stem sawfly. (Cephus cinctus Norton). Journal Heredity, v. 89, n. 4, p. 329-335, 1998. 
LOXDALE, H. D.; HARDIE, J.; HALBERT, S.; FOOTTIT, R.; KIDD, N. A. C.; CARTER, C. I. The relative importance of short-and long-range movement of flying aphids. Biological Reviews of the Cambridge Philosophical Society, v. 68, n. 2, p. 291-311, 1993.

LOXDALE, H. D.; LUSHAI, G. Molecular markers in entomology. Bulletin of Entomological Research, v. 88, n. 6, p. 577-600, 1998.

LOXDALE, H. D.; BROOKES, C. P.; DE BARRO, P. J. Application of novel molecular markers (DNA) in agricultural entomology. In: SYMONDSON, W. O. C.; LIDDELL, J. E. (Ed.) The ecology of agricultural pests: biochemical approaches. London: Chapman and Hall, 1996. p. 149-212.

LYNCH, M.; MILLIGAN, B. G. Analysis of population genetic structure with RAPD markers. Molecular Ecology, v. 3, n. 2, p. 91-99, 1994.

MADDEN, L. V.; NAULT, L. R. Differential pathogenecity of com stunting mollicutes to leafhopper vectors in Dalbulus and Baldulus species. Phytopathology, v. 73, $\mathrm{n}$. 12, p. 1608-1614, 1983.

MADDEN, L. V.; NAULT, L. R.; HEADY, S. E. ; STYER, W. E. Effect of maize stunting mollicutes on survival and fecundity of Dalbulus leafhoppers vectors. Annals of Applied Biology, v. 105, n. 3, p. 431-441, 1984.

MAGAlhãeS, P. C.; DURÃES, F. O. M.; PAIVA, E. Fisiologia da planta de milho. Sete Lagoas: Empresa Brasileira de Pesquisa Agropecuária - EMBRAPA, 1995. (EMBRAPA. Circular Técnica, 20).

MARGARITOPOULOS, J. T.; MAMURIS, Z; TSITSIPIS, J. A. Attempted discrimination of Myzus persicae and Myzus nicotianae (Homoptera: Aphididae) by randon amplified polymorphic DNA polimerase chain reaction technique. Annals of the Entomological Society of America, v. 91, n. 5, p. 602-607, 1998. 
MARÍN, R. Bilogia y comportamiento de Dalbulus maidis (Homoptera-Cicadellidae). Revista Peruana de Entomologia, v. 30, p. 113-117, 1987.

MARKHAM, P. G; TOWNSEND, R.; PLASKITT, K.; SAGLIO, P. Transmission of corn stunt to dicotyledonous plants. Plant Disease Reporter, v. 61, n. 5, p. 342345, 1977.

MASAKI, S. Summer diapause. Annual Review of Entomology, v. 25, p. 1-25, 1980.

MASSOLA JÚNIOR, N. S.; BEDENDO, I. P.; AMORIM, L.; LOPES, J. R. S. Quantificação de danos causados pelo enfezamento vermelho e enfezamento pálido do milho em condições de campo. Fitopatologia Brasileira, v. 24, n. 2, p. 136-142, 1999.

McNAB, B. K. On the ecological significance of Bergmann's rule. Ecology, v. 52, n. 5, p. $845-854,1971$.

MENDES, L. O. T. Observações sobre alguns insetos coletados sobre algodoeiro durante os anos de 1936 e 1937. Boletim técnico do Instituto Agrônomico, v. 45, p. $1-15,1938$.

MENEZES, M. Contribuição ao estudo da subfamilia Deltocephalinae (Homoptera: Cicadellidae) no Estado de São Paulo. Piracicaba, 1972. 146p. Tese (Doutorado) - Escola Superior de Agricultura "Luiz de Queiroz", Universidade de São Paulo.

MOWAT, W. P.; DAWSON, S. Detection of plant viruses by ELISA using crude sap extracts and unfractioned antisera. Journal of Virological Methods, v. 15, p. 233-247, 1987.

MURPHY, E. C. Bergmann's rule, seasonality, and geographic variation in body size of house sparrows. Evolution, v. 39, n. 6, p. 1327-1334, 1985. 
NCGA NATIONAL CORN GROWERS ASSOCIATION. The world of corn. Pioneer Hi-Bred International, Inc., 1997. 39p.

NAULT, L. R. Mayze bushy stunt and corn stunt a comparison of disease symptoms, pathogens host ranges, and vectors. Phytophatology, v. 70, n. 7, p.659-662, 1980.

NAULT, L. R. Evolutionary relationships between maize leafhoppers and their host plants In: NAULT, L. R. ; RODRIGUEZ, J. G. (Ed.) The leafhoppers and planthoppers. New York: John Wiley, 1985. p. 309-330.

NAULT, L. R. Evolution of insect pest: maize and leafhopper, a case study. Maydica, v. 35, n. 2 , p. $165-175,1990$.

NAULT, L. R. Arthropod transmission of plant viruses: a new synthesis. Annals of the Entomological Society of America, v.90, n. 5, p. 521-541, 1997.

NAULT, L. R.; BRADFUTE, O. E. Corn stunt: involvement of a complex of leafhopper-borne pathogens In: MARAMOROSCH, K.; HARRS, K. F. (Ed.) Leafhopper vectors and plant disease agents. New York: Academic Press, 1979. p.561-586.

NAULT, L. R; DeLONG, D. M. Evidence for co-evolution of leafhoppers in the genus Dalbulus (Cicadellidae: Homoptera) with maize and its ancestors. Annals of the Entomological Society of America, v. 73, n. 4, p. 349-353, 1980.

NAULT, L. R. ; STYER, W. E. High elevation gamagrassis host two new endemic Dalbulus species in Mexico (Homoptera: Cicadellidae). Annals of the Entomological Society of America, v. 87, n. 3, p. 257-262, 1994.

NAULT, L. R.; GORDON, D. T.; CASTILLO-LOYAZA, J. Maize virus and mycoplasma disease in Peru. Tropical Pest Managenment, v. 27, n. 3, p. 363-369, 1981. 
OAKENFULL, E. A. Vodka, meths and DNA. Trends in Ecology and Evolution, v. 9, p. $26,1994$.

OLIVEIRA, C. M. Variação morfológica entre populações de Dalbulus maidis (DeLong \& Wolcott, 1923) (Hemiptera: Cicadellidae) de algumas localidades do Brasil. Piracicaba, 1996. 69p. Dissertação (Mestrado) - Escola Superior de Agricultura "Luiz de Queiroz", Universidade de São Paulo.

OLIVEIRA, E.; WAQUIL, J. M.; FERNANDES, F. T.; PAIVA, E.; RESENDE, R. O.; KITAJIMA, E. W. "Enfezamento pálido" e "Enfezamento vermelho" na cultura do milho no Brasil Central. Fitopatologia Brasileira, v. 23, n. 1, p. 45-47, 1998.

OLIVEIRA, E.; WAQUIL, J. M.; PINTO, N. F. J. A. Doenças causadas por patógenos transmitidos por insetos: complexo enfezamento/mosaico In: SEMINÁRIO SOBRE A CULTURA DO MLLO "SAFRINHA", 4, Assis, 1997. Anais. Assis: IAC/CDV, 1997. p. 87-94.

OMAN, P. W. Distribuition of Baudulus maidis (DeLONG \& WOLCOTT). Proceedings of the Entomological Society of Washington, v. 50, n. 2, p. 34, 1948.

PASCUAL, M.; SERRA, L. RAPD diagnosis of the obscura group species sympatric with $D$. subobscura in North America. Journal of Heredity, v. 90, n. 5, p 580-582, 1999.

PEDIGO, L. P. Entomology and pest management. New York: Macmillan Publishing Company, 1989. cap. 5, p.167-192: Insect Ecology.

PIENKOWISKI, R. L.; MEDLER, J. T. Synoptic weather conditions associated with long-range movement of the potato leafhopper, Empoasca fabae, into Wisconsin. Annals of the Entomological Society of America, v. 57, n. 5, p. 588-591, 1964. 
PITRE, H. N.; COMBS, R. L.; DOUGLAS, W. A. Gamagrass, Tripsacum dactyloides: a new host of Dalbulus maidis, vector of corn stunt virus. Plant Disease Reporter, v. 50, n. 8 , p. $570-571,1966$.

PORNKULWAT, S.; SKODA, S. R.; THOMAS, G. D.; FOSTER, J. E. Random amplified polymorphic DNA used to identify genetic variation in ecotypes of the european corn borer (Lepidoptera: Pyralidae). Annals of the Entomological Society of America, v. 91, n. 5, p. 719-725, 1998.

POST, R. J.; FLOOK, P. K.; MILLEST, A. L. Methods for the preservation of insects for DNA studies. Biochemical Systematics and Ecology, v. 21, n. 1, p. 85-92, 1993.

POWELL, J. R.; TABACHNICK, W. J.; ARNOLD, J. Genetics and the origin of a vector population: Aedes aegypti, a case study. Science, v. 208, n. 4450, p. 1385$1387,1980$.

PROKOPI, R. J. Response of apple maggot flies to rectangles of differents colors and shades. Environmental Entomology, v. 1, n. 6 , p. 720-726, 1972.

PROKOPI, R.J.; OWENS, E.D. Visual detection of plants by herbivorous insects. Annual Review of Entomology, v. 28, p. 337-364, 1983.

PUTERKA, G. J.; BLACK, W. C. IV.; STEINER, W M.; BURTON, R. L. Genetic variation and phylogenetic relationships among worldwide colletions of the Russian wheat aphid, Diuraphis noxia (Mordvilko), inferred from allozyme and RAPD-PCR markers. Heredity, v. 70, n. 6, p. 604-618, 1993.

QUINTERO, C.; CARDONA, C.; RAMÍREZ, D.; JIMÉNEZ, N. Primer registro del biotipo B de Bemisia tabaci (Homoptera: Aleyrodidae) en Colombia. Revista Colombiana de Entomologia, v. 24, n. 1-2, p. 23-28, 1998. 
RAEDER, U.; BRODA, P. Rapid preparation of DNA from filamentous fungi. Letters in Applied Microbiology, v. 1, n. 1, p. 17-20, 1985.

RAUSHER, M. D. The effect of native vegetation on the susceptibility of Aristolochia reticulata (Aristolochiaceae) to herbivore attacks. Ecology, v. 62, n. 5, p. 1187$1195,1981$.

REINEKE, A.; ZEBITZ, C. P. W. Suitabilidade of polymerase chain reaction-based approaches for identification of different gypsy moth (Lepidoptera: Lymantriidae) genotypes in Central Europe. Annals of the Entomological Society of America, v. 92, n. 5, p. 737-741, 1999.

REISS, R. A.; SCHWERT, D. P.; ASHWORTH, A. C. Field preservation of Coleoptera for molecular genetic analyses. Environmental Entomology, v. 24, n. 3, p. 716$719,1995$.

REYES, A.; OCHANDO, M. D. Use of molecular markers of detecting the geografical origin of Ceratitis capitata (Diptera: Tephritidae) populations. Annals of the Entomological Society of America, v. 91, n. 2, p. 222-227, 1998.

RILEY, J. R.; REYNOLDS, D. R.; FARROW, R. A. The migration of Nilaparvata lugens (Stål) (Delphacidae) and other Hemiptera associated with rice during the dry season in the Philippines: a study using radar, visual observations, aerial neting and ground trapping. Bulletin of Entomological Research, v. 77, n. 1, p. 145-169, 1987.

RILEY, J. R.; REYNOLDS, D. R.; SMITH A. D.; EDWARDS, A. S.; ZHANG, X. X.; CHENG, X. N.; WANG, H. K.; CHENG, J. Y.; ZHAI, B. P. Observation of the autumn migration of the rice leaf roller Cnaphalocrocis medinalis (Lepidoptera: Pyralidae) and others moths in eastern China. Bulletin of Entomological Research, v. 85, n. 3, p. 397-414, 1995. 
RODERICK, G. K. Geographic structure of insect populations: gene flow, phylogeography, and the uses. Annual Review of Entomology, v. 41, p. 325-352, 1996.

ROLF F. J. NTSYS-pc Numerical taxonomy and multivariate analysis system version 1.7. Owner Manual, 1992, $101 \mathrm{p}$.

SAIKI, R. K.; GELFAND, D. H.; STOFFEL, S.; SCHARF, S.; HIGUSHI, R. H·; HORN, G. T.; MULLIS, K. B.; ERLICH, H. A. Primer-directed enzymatic amplification of DNA with a thermostable DNA polymerase. Science, v. 239, n. 4839, p. 487-491, 1988.

SAMBROOK, J.; FRITSCH, E. F.; MANIATIS, T. Molecular Cloning: a laboratory manual. 2nd ed., New York, Cold Spring Harbor Laboratory Press, 1989.

SAS Institute. SAS/STAT user's guide: release 6.088 ed. Cary, 1993.

SCHELTES, P. The condition of the host plant during aestivation-diapause of the stalks borers Chilo partellus and Chilo orichalcociliella (Lepdoptera, Pyralidae) in Kenya. Entomologia Experimentalis et Applicata, v. 24, n. 3, p 679-688, 1978.

SCHNELL, R. J.; MADEIRA, P. M.; HENNESSEY, M. K.; SHARP, J. L. Inherintace of random amplified polymorphic DNA markers in Anastrepha suspensa (Diptera: Tephritidae). Annals of the Entomological Society of America, v. 89, n. 1, p. 122$128,1996$.

SCHREIBER, D. E.; GARNER, K. J.; SLAVICEK, J. M. Identification of three randomly amplified polymorphic DNA - polimerase chain reaction markers for distinguishing Asian and North American gypsy moths (Lepidoptera: Lymantriidae). Annals of the Entomological Society of America, v. 90, n. 5, p. 667-674, 1997. 
SHUFRAM, K. A.; BURD, J. D.; WEBSTER, J. A. Biotypic status of russian wheat aphid (Homptera: Aphididade) populations in the United States. Journal of Economic Entomology, v. 90, n. 6, p. 1684-1689, 1997.

SILVA, A. G. d'A.; GONÇALVES, C. R.; GALVÃO, D. M.; GONÇALVES, A. J. L.; GOMES, J.; SILVA, M. N.; SIMONI, L. Quarto catálogo dos insetos que vivem nas plantas do Brasil, seus parasitos e predadores. Parte II - $1^{o}$ Tomo- Insetos, hospedeiros e inimigos naturais. Rio de Janeiro: Ministério de Agricultura, Departamento de Defesa e Inspeção Agropecuária, 1968. 662 p.

SILVA, H. P.; PEREIRA, O. A. P.; MACHADO, J.; MONELLI, V. L. Identificação e controle das doenças do milho. Informativo Coopercitrus, v. 6, n. 61, p. 18-24, 1991.

SILVEIRA, E. B.; ALJANABI, S. M. ; MAGAlhãES, B. P. ; CARVALHO, L. J. C. B.; TIGANO, M. S. Polymorphism of the grasshopper Schistocerca pallens (Thunberg) (Orthoptera: Acrididae) and its natural patogen Metarhizium flavoviride Gams \& Rozsypal (Hyphomycetes), revealed by RAPD analysis. Anais da Sociedade Entomológica do Brasil, v. 27, n. 1, p. 91-99, 1998.

SIMONET, D. E.; PIENKOWISKI, R. L. Temperature effect on development and morphometrics of the potato leafhopper. Environmental Entomology, v. 9, n. 6, p. 798-800, 1980.

SKINNER, D. Z.; CAMACHO, R. F. Genetic diversity within a potato leafhopper (Homoptera: Cicadellidae) population infesting alfafa. Journal of the Kansas Entomological Society, v. 68, n. 1, p. 35-42, 1995.

SMITH, J. G. Influence of crop background on aphids and other phytophagus insects on brussel sprouts. Annals of Applied Biology, v. 83, n. 1,p. 1-13, 1976. 
SMITH, L. J.; BRAYLAND, R. C.; NUTKIS, J. E.; EDMUNDSON, K. B.; DOWNING, J. R.; WAKELAND, E. K. Extraction of cellular DNA from human cells and tissues fixed in ethanol. Analytical Biochemistry, v. 160, n. 1, p. 135-138, 1987.

SNEATH, P. H. A.; SOKAL, R. R. Numerical Taxonomy. San Francisco: W. H. Freeman, 1973. $573 \mathrm{p}$.

SOLBRECH, C. Insect migration strategies and populations dynamics. In: RANKIN, M. A. (Ed.) Migration: mechanisms and adptative significance. Port Aransas: Marine Science Institute, 1985. p. 641-662.

SOUTHWOOD, T. R. E. Migration of terrestrial arthropods in relation to habitat. Biological Reviews of the Cambridge Philosophical Society, v. 37, n. 2, p. 171$214,1962$.

SOUTHWOOD, T. R. E. The role and measurement of migration in the population system of a insect pest. Tropical Science, v. 13, n. 4, p. 275-278, 1971.

SOUTHWOOD, T. R. E. Habitat, the templet for ecological strategies? Journal of Animal Ecology, v. 46, p. 337-365, 1977.

SOUTHWOOD, T. R. E. Ecologicals aspects of insect migration. In: AIDLEY, D. J. (Ed.) Animal migration. Cambridge: Cambridge University Press, 1981. p. 196208 .

SUAZO, A.; McTIERNAM, R.; HALL. H. G. Differences between african and european honey bee (Apis mellifera L.) in Random Amplified Polymorphic DNA (RAPD). Journal of Heredity, v. 89, n. 1, p. 32-36, 1998. 
SUNNUCKS, P.; DRIVER, F.; BROWN, W. V.; CARVER, M.; HALES, D. F.; MILNE, W. M. Biological and genetic characterization of morphologically similar Therioaphis trifolli (Hemiptera: Aphididae) with different host utilization. Bulletin of Entomological Research, v. 87, n. 4, p. 425-436, 1997.

SWALLOW, W. H. Group testing for estimating infection rates and probalities of disease transmission. Phytopathology, v. 75, n. 8, p. 882-889, 1985.

SYMONDSON, W. O. C.; LIDDELL, J. E. The ecology of agricultural pests: biochemical approaches. 1 sd ed., London, Chapman \& Hall, 1996. 517p.

TAYLOR, L. R. Insect migration flight periodicity, and boundary layer. Journal of Animal Ecology, v. 43, p. 225-238, 1974.

TAYLOR, L. R.; TAYLOR, R. A. J. Aggregation, migration and population mechanisms. Nature, v. 265, n. 5593, p. 415-421, 1977.

TAYLOR, L. R.; TAYLOR, R. A. J. Insect migration as a paradigm for survival by movement. In: SWINGLAND, I. R.; GREENWOOD, P. J. (Ed.) The ecology of animal movement. Oxford: Claredon Press, 1983 p., 181-214.

TAYLOR, R. A. J. Migratory behavior in the Auchenorrhyncha. In: NAULT, L. R. ; RODRIGUEZ, J. G. (Ed.) The leafhoppers and planthoppers. New York: John Wiley, 1985. p. 259-288.

TAYLOR, R. A. J.; NAULT, L. R.; STYER, W. E. Experimental analysis of flight activity of three Dalbulus leafhoppers (Homoptera: Auchenorrhyncha) in relation to migration. Annals of the Entomological Society of America, v. 86, n. 5, p. 655$667,1993$.

TERAGUCHI, S. E. Migration patterns of leafhoppers (Homoptera: Cicadellidae) in an Ohio old field. Environmental Entomology, v. 15, n. 6, p. 1199-1211, 1986. 
THORMANN, C. E.; FERREIRA, M. E.; CAMARGO, L. E. A.; TIVANG, J. G.; OSBORN, T. C. Comparison of RFLP and RAPD markers to estimating genetic relationships within and among cruciferous species. Theoretical and Applied Genetics, v. 88, n. 8, p. 973-980, 1994.

TINGEY, S. V.; TUFO, J. P. DEL. Genetic analysis with random amplified polymorphic DNA markers. Plant Physiology, v. 101, n. 2, p. 349-352, 1993.

TODD, J. L.; HARRIS, M. O. ; NAULT, L. R. Importance of color stimuli in hostfinding by Daubulus leafhoppers. Entomologia Experimentalis et Applicata, v. 54 , n. 3, p. 245-255, 1990a.

TODD, J. L.; MADDEN, L. V. ; NAULT, L. R. Comparative growth and spatial distribution of Dalbulus leafhoppers populations (Homopetra: Cicadellidae) in relation to maize phenology. Environmental Entomology, v. 20, n. 2, p. 556-564, 1991.

TODD, J. L.; PHELAN, P. L.; NAULT, L.R. Orientation of the leafhopper, Dalbulus maidis (Homoptera: Cicadellidae), to different wavelengths of reflected light. Journal of Insect Behavior, v. 3, n. 4, p. 567-571, 1990 b.

TRIPLEHORN, B. W. ; NAULT, L. R. Phylogenetic classification of the genus Dalbulus (Homoptera: Cicadellidae), and notes on the phylogeny of the Macrostelini. Annals of the Entomological Society of America, v. 78, n. 3, p. 291-315, 1985.

TRIPLEHORN, B. W.; SHAMBAUGH, G. F.; HAMILTON, D. F.; NAULT, L. R. Isoenzyme analysis of the genus Dalbulus (Homoptera: Cicadellidae). Annals of the Entomological Society of America, v. 83, n. 4, p. 694-704, 1990. 
TSAI, J. H. Bionomics of Dalbulus maidis (DeLong \& Wolcott): a vector of mollicutes and virus (Homoptera: Cicadellidae) In: MARAMOROSCH, K.; RAYCHAUDHURI, S. P. (Ed.) Mycoplasma diseases of crops: basic and applied aspects. New York: Springer-Verlag, 1988. p. 209-221.

USUA, E. J. Induction of diapause in the maize stemborner, Busseola fusca. Entomologia Experimentalis et Applicata, v. 16, n. 2, p. 322-328, 1973.

VAUGHN, T. T.; ANTOLIN, M. F. Population genetics of an opportunistic parasitoid in an agricultural landscape. Heredity, v. 80, n. 2, p. 152-162, 1998.

WAQUIL, J. M. Amostragem e abundância de cigarrinhas e danos de Dalbulus maidis (DeLong e Wolcott) (Homoptera: Cicadellidae) em plântulas de milho. Anais da Sociedade Entomológica do Brasil, v. 26, n. 1, p. 27-33, 1997.

WAQUIL, J. M.; VIANA, P. A.; CRUZ, I.; SANTOS, J. P. Aspectos da biologia da cigarrinha-do-milho, Dalbulus maidis (DeLong \& Wolcott) (Hemiptera: Cicadellidae). Anais da Sociedade Entomológica do Brasil, v. 28, n. 3, p. 413$420,1999$.

WAQUIL, J. M.; OLIVEIRA, E.; PINTO, N. F. J. A.; FERNANDES, F. T.; CORREA, L. A. Efeito na produção e incidência de viroses em híbridos comerciais de milho. Fitopatologia Brasileira, v. 21, n. 4, p.460-463, 1996.

WELSH, J; MCCLELLAND, M. Fingerprinting genomes using PCR with arbitrary primers. Nucleic Acids Research, v. 18, n. 22, p. 7213-7218, 1990.

WILLIAMS, J. G. K.; KUBELIK, A.R.; LIVAK, K. J.; RAFALSKI, J. A.; TINGEY, S. V. DNA polymorphism amplified by arbitrary primers are useful as genetics markers. Nucleic Acids Research, v. 18, n. 22, p. 6531-6535, 1990. 
WU, G. R.; YU, P. X.; TAO, L. Y.; REN, Z. J. Wing dimorphism and migration in the brown planthopper, Nilaparvata lugens Stål. In: DANKS, H. V. (Ed.) Insect lifecicle polymorphism. Dordrecht: Kluwer Academic, 1994. p. 263-276.

XU, M.; SUN, S.; WANG, R.; LI, S. Genetic variation and phylogenetic relationships among six populations of corn borers in China. Biochemical Genetics, v. 36, $n$. 7/8, p. 289-297, 1999.

ZERA, A. J. Wing polymorphism in waterstriders (Gerridae: Hemiptera): mechanism of morph determination and fitness diferences between morphs. In: RANKIN, M. A. (Ed.) Migration: mechanisms and adptative significance. Port Aransas: Marine Science Institute, 1985. p. 674-686. 
APÊNDICES 


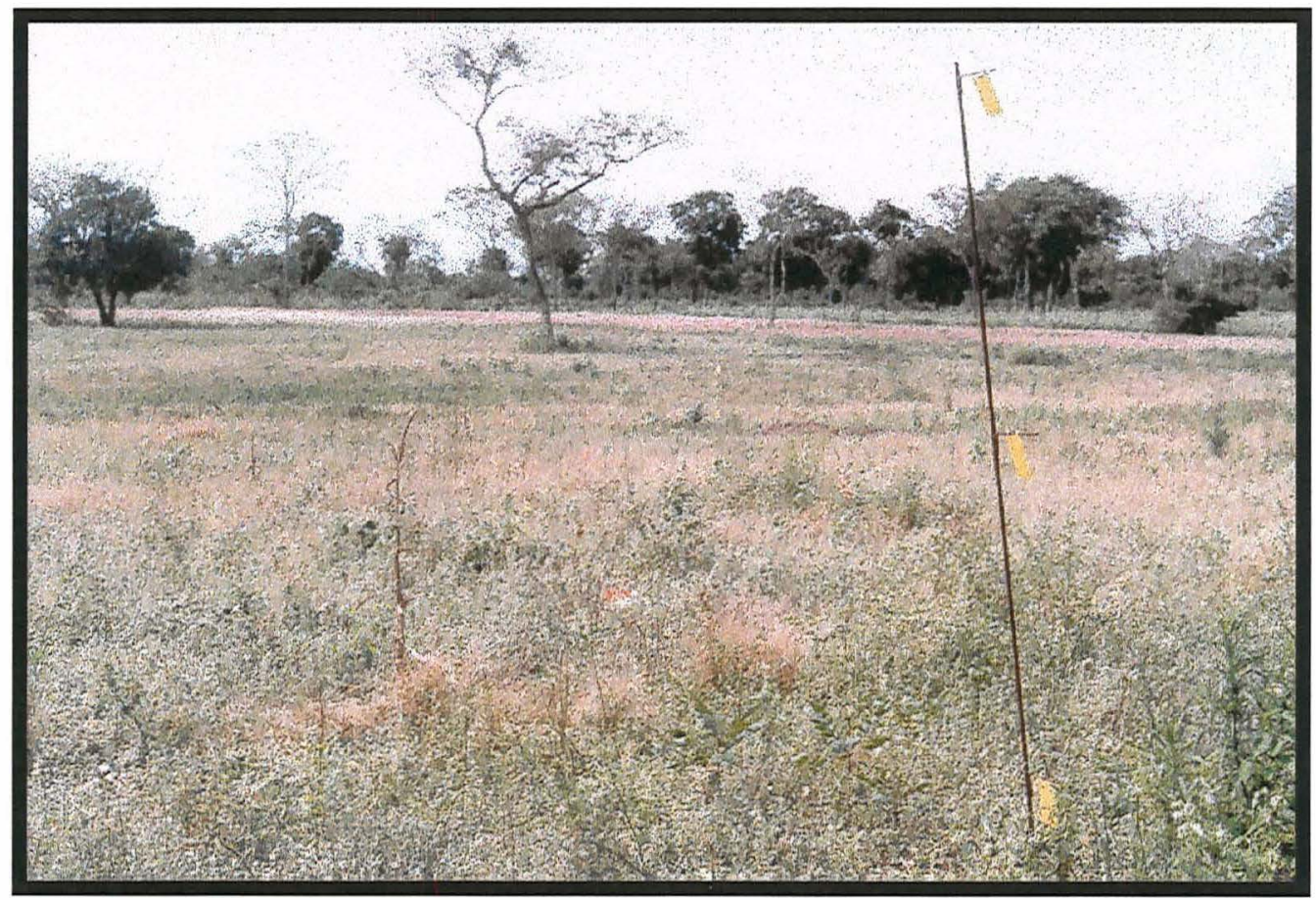

Apêndice 1. Visão geral de uma das áreas experimentais em Anastácio/MS (área IV), após o cultivo do milho, mostrando o vergalhão contendo cartões adesivos amarelos dupla face nas alturas de $0,5,1,5$ e $2,5 \mathrm{~m}$. 


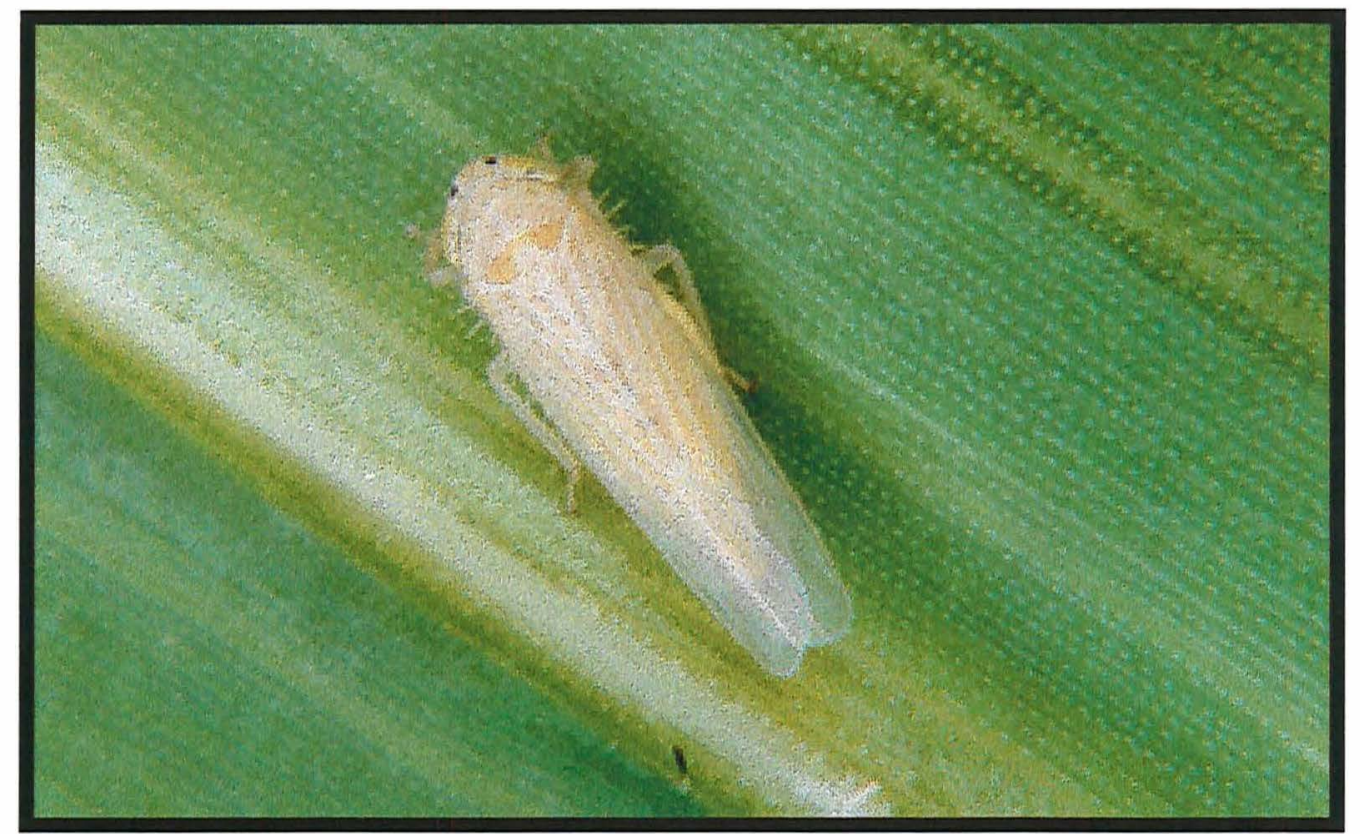

Apêndice 2. Adulto da cigarrinha-do-milho, Dalbulus maidis (DeLong e Wolcott, 1923) (Hemiptera: Cicadellidae). 
1011010111101101011110110111101001010101110110101000010001000110111100001111100001011111010011101100110111111011101010010101010110101 10010101111011010111110100101101001010100000111101101010001001110111101010111000001011110011011101110010110110011101010010111111111101 10110101111011110111111101101010010101011001101011000101010001101111010101111010010111110111111010001011111100110101001011101111101 0000010111101111011111111111001001011100110101101001110101100000111100010111101001011111011111101100010111111011101010011101010111111 00010111111011010111110100111001001010101000101101111010100000110111000010111100101011111011111101110110111111011101011011101010010101 10110101111011010111110101111001101010101110111101101010111000010111100010111100001011111011111101100010111111111101010000111110110101 00111101111011010111110101111011101010110111111111101110101000010111100010111100001011111011111101110010101111101101011010111010110101 10110101111011010111111110110101001010100110111101101010100000010111101010111100001011110011111101100110111111111101010010111010111101 1011010111101101011111110111001001010101110011101100010110000110111100010111101001011111011111101101010110111111101010010111011111101 1011010111101101011111011111001001010100111111101101110000000010111100010111100001011111011111101100010111110111101010010101010110101 1011010111101101011011011011101100101110111010110110001011100100011110001011110000101111101111110110001011111101110101001010111011110 1011010111101101011011011011100100101010110011111110101010000001011110001011110100101111001111111110001010111011110001001111101011110 10010101111011010111110111111001001010100110111111101010100000110111100010111100001011110011111101111010111111011101010011111111111101 10010101101011010110110110110101001010100110111101100010111000010111100010111100011011111011011111000101111111110101001111111011101 0011010111101101011011011011101001101010110101101101010111000110111100010111101001011111011111111000101111111110101101111010111101 100101011111110101111011011100100101010011000111110101011100001011110001111110000101111001111110110011011011111101010010111110111101 1101010111101101011011011011100100001011111010010100001000100011111110001011110101101111101111110110011011111111101011010101010111101 00110101111011010110110101111001101011101100111100001011001000010111100010111101001011110001011101100010111111111101010011111110110101 11010101101011010110110100111011001010101110111101101010101000010111100010111101001000111011111111100010111111001101010010101010110111 11110101111011010110110101111101001010100100111101101010100011010111100010111100001011111001111101100010101111011101010010110110110101 0001010110111101011011011011100100101010011000110100001001000101011110001011110000101111100111110110001011111111110101000011111011101 1011010111101101011111011001100100001110110011110100001010100001011110001111111100101111001111110010101011111111101010010111010111101 101101011110110101101101101110011001001011001111011010101100011101111000101111010010111110111111011100101111111110101001010100111110 10100101111111010110110110111011001010101110011101101010100000010111100010111100001011111011111101101010100011111101010010101110111101 1011010110101101011111011011111101010100010111111001010100000110111010010111101001011111011101101111010111010111101010010101110110100 1011010110101101011011111011110100101010110011111100101010100001011110001011110100101011001101110111001011111111110101000110111110100 000101011110110101111111101101010010101000101111011010101010100101111000101111000010111110111111101100101111011110101001011101111110 00110101101011010111110111111001001010101110111100101010110000000111100010111100001011110001111111110010111010011111010010111010111100 01000101101011011111110111111011001110111110110001111010001001010111101010111100101011111011011100100010111111001101010000111110101111 01010101111011010110110110110101001010111010111111001010001000011111100110111111001011110011111100100010111111111100010010111010111101 10010101101011010110110111111001001010101100101101101010101000010111100010111100001011111011111101110010111111111101010010111010110101 101101011010110101111101101111010010101011001111011010101000000101111000101111000010111110111110110001011111111101010010111010110101 1011010110101101011110110111011001010101100111110101010001000010111100001111100001011111011011101101010111111111101010011111010111101 00110101111011010111110111111101001010101110001110101010101000110111100010111101001111111011101101100010111111111101010000111111111100 0010010111101101011111011011100100101010011111110010111010000001011110001011110100101111001111110110001011111101110101001011110101110 10010101101111010110110110111001101011101010101111100011101000100111000010111100001011111011111101100010111110101101010010101010111101 10110101111011010110110110111001001010101010111101001010101010110111100010111100001011110011111101100010110110101101010010101010111101 10110101100011110110110111111010010101011101100011000111010100101111000101111000010111110111111111001011001011110101001110111011101 1011010111101101011011011011110110101010000011110110001010001000011110001011110000101111000111110110000011111111101010010110100110101 10110101101011010111110110111001001010101100101101000010110000000111100010111101001011110011011101100010110111111101010000101010111101 10110101111011010111110110111101001011100010011101100010101000010111100010111100001011111011011101100010111111011101010010101110110101 10110101101011010110110111111001001010101110111101100010101000010111100010111101001011111011101101100010111111011101010011111111100101 10110101111011010110110110111001001010101110011111101010100000110111100010111101001011111011101101100010111110111101010000111010111101 10110101111011010111110111111101001010100110111101100010101000010111100010111101001011110111011101100010101111111101010010101110111101 10110101101111010110110110111011001011101110010000001010101010100111100010111101001011110010111101100010110011111101010000101110110101 10010101111011010111110111111001001010100110101101101010110000010111100010111100001011110011101101000010110111111101010000101010110100 1011010111101101011111111011010100101110111010001110001110100001011110001011110100101111101110110100001011111011101010011101010110100 10110101111011010111110110111101001010100010011101100010101000010111100010111101001011111001101101100110111110011101010000111011111101 10110101101011010110110110011001001010101110111101101011111001010111100010111101001011110011011101100010110110011101010010111010111101 10100101111011010111110110110011111010100001111101101010101000010111100000111100101011110000111101110010111111011101011001101101110100 1101010111101101011111011111010100101011111011110100001010100001011110001011110000100111001111110011101011111111101010011110111110100 10110101101011010110110110111001001010101110111101100010100000010111110010111101001010111111111101100010111111111101010011101110011101 1011010111101101011111110111001001010100110101111100110101010010111100010111100101011110011011101110010111111111101010010111011110101 1001010111111101011111011011100100101110111011110110101011000101011110001011110100101111101111110110001111111031101011011101010110100 101101011110110101101101111100100101010011011110110001011000001011110001011110100101111101111110110001011111101110101001011111011101 10111101101011010111110110111010011010101110111101101011100010110111100010111100001011110001111101110011101110111101010011101010111101 10100101111011010111110110111001100010100110111111110010100001010111100010111100001011110011111101100010111110111101010111111010111101 10110101111011010110110111111101001011101110111111000010111000000111101010111100001011110011011101100110111111111101010010111110111100 10100101111011010110110110111001101110101110111101101010100000010111100010111100001011110011111100100010111111111101010010101110110101 10110101111011010110110110111001001010101110100001101010000001000111100110111100001011110001111100100010110110111101011011111010011101 101101011110110101101101101101010010101011101011111010101010000101111000101111011010111110110111110001011111111101010000111010110101 10100001111111010111101111110110010111000101111011010111000000101111000101111010010111100111111011000111111110110101100011111111101 10110101111011010111110110111011011010101110111111101010001010100111101010111101001011111011111101100110110111101101010011111110111101 10110101111011010111110111111101001010110110111100101010101010010111100010111101001011111011011101110010111111111101010010101010111101 10110101111110101111101101111011010101001101111011010100010100101111000101111001010111110110111011101101111111110111001011101011110 10110101111011010111110110111110010101001101111110101011000001011110001011110001101111001111110110001011111111101010010101111011101 1011010110101101011111011010101111101010111010110110101000100011111110001011110000101111101111110110001011111111101010010101011111101 1011010111101101011011011011100100101011110111111101010001000010111100010111101001011110000001111100010101111011101010010101111111100 1000010110101101011011011111100100101010111011110110101000100001011110001011110000101111101111110110001011111110101010001101110111101 1001010111101101011111011011100100101010111011110110101000100001011110001011110000101111101101110110001011111010110101000010111111101

\section{Apêndice 3. Matriz binária obtida a partir da leitura de fotografias de géis de agarose} $1,4 \%$, contendo produtos de amplificação via RAPD-PCR do DNA da cigarrinha-do-milho, Dalbulus maidis, coletadas em quatro áreas experimentais localizadas em Anastácio/MS nas safras 1997/1998. Áreas I e II - plantio do milho em única safra anual há pelo menos 5 anos; áreas III, IV - áreas de pastagem sem plantio de milho há mais de 5 anos. As letras ao lado da identificação das áreas indicam $\mathrm{A}$ - cigarrinhas coletadas no ínicio da safra do milho e B- coleta no meio ou final da safra. 
1A-1

1011110111100011010101011001111001101000100110001001110111110001011010000101010100010111110000011011001111100001000111110001010011110011000101000110101111011011010111011101001010100 01011011010001101010101101111101101000100110000001110100010001010001000001001000010011110000011011001111010010001011100101001111101110010100001010011110001010111011001001010100 10101101111111100010111100111100110100011011100010111010011001101001011010110010000011111001001101100111111000100010111101010011110011000101101000100111011001010111011001001010100 101011011110011100010101100111110110100011011000100111010111110101101111010111100000011111100001101110111111001100010111110111001111111100010110101010111111001010101011101001010000 1010110111100111000101111001111001101000100110001001110100010001110010110101000100000011110100011011001111100001000101111001010101110011010101101011101111011001010111011001001010100 101101011110101100010101100111110110100011001000100111010111000111101000010110100000001111001101111100111110111100010111000101001111001000010110001010111111011011111011101011011101 10101001110001110111010110011111011010001001100010011101101100001110001101010001000000111111001101100111110011000101110101010011110011000101101011101111011011010111010001001011100 1010110111101111010101011001111001101000100110001001110100110001011111000101000100000011111011011111001111100001000101110111010011110011000101100010101101011011010111011101001011100 1101110101100111010101011011111001101000110110001001110100110101111011000101101000000011110010011011001111100011000101111101010011110011000101101010101101011011010111011001001011100 101111011110111111010101101111100111100011011000100111010111010011101111010010010011011111001101111100111110001100110111000001000111011100010110001110111111011010100111101001111100 1011110111100111011101111001111001101000101110000101110100110101101011110101011100000011111010011011001111100011000101111011010011110111100101100000101111011011000111011101011011101 1010110111000111010101011001111101101000100110001001110100110101110011110101100100000011110000011011001111100101100101111101010011110011000101101010101111011011010111011001001011100 10001101010001110101010110011111011010001001100011011011001101010110110001010000001100111110100110110011110000100110111101010001110001000101101010101111011011011111010001001011100 10111101101001110101011110011110011010001001100010011101000111010111111010110100000001111001001101100111110001000101110001010011110011100101100010101111011011010111011101001011100 1010110111100101000101011001111011010001001100010011110001101111001000101110000001111100001101100111101011000101110010101101101100010110001110111111001010111011001001010001 10101101111000111101110110011111111000100110001001111000100010110101101011111001000111100010110110011110011100010111001010001110011000101101010101111011011010111011101001010000 101111011110010101010101100111110110100010011000100111010101010111101111010111010001001111101001101100111110000100010111110101001111001100010110101010111011011000111011101011011100 1010110101100101116111011001111011101000110110001011110101010011111011110100000010001011111011011011001110011011000101111101111111001100010110101110111111001110111011011001011100 1010111101011110111010100011110111110101100101010011101000110011110100011110000010011111101011101100111110001101010111111010011110011100111100000100100111101000111011001001011101 10101101111001110001010110011110011010001101100010011111000101010000111101011101000001111100100110110010100000010001011110101001111001100010110001010111111011010111011001001011100 1110110111100111010101111001111011010001001100101011101000101011111011011110010000001111001001101100111111001000101011101010011110011000101001010101111011011000111011001001011100 101011011010011101010101100111100110100011011000100111010001000111111110101101100000011110010011011001111110011000101110101010011110011100101111011101111011011010111011001001011100 1010110110101011010101011001111101101000100110000001110100110101111011000101100100000011110010011011001111110001000101111101010011111111000101101010101111011011010111011001011011100 1010110110100111010101011001111001111000110110001101110110110101111011000101010100100011111010011011001111110001000101111111010001110011100101100010101111111011010111011101001011100 1110110111100111000101011001111001101000100110011001100100111101111011110101010100010011111010011011001110000011000111111101010011110011000101100110101111011011010111010001001010100 10101101101001110101010110011110011010001101100010011111001100111110111101011000000100111110100110110011111001100010111110011000111001100010110101010111111011011111011001001011100 1011110111101111010111111001111101101100101110001001110100010001111011110101101100000011110010011011001111100011000101111101010011110011000101100010101111011011010111011001001010000 (1) 01111011100011001101110011110011010001101100010011101000101011111011010110110000011111010011011001111110110001011111010100111111100010110001010111111011010111010001001010001 101011011010011101010101100111100110110010011000100111110011000111111110101110100100111110010011011001111100001000101111001010001111011000101100110101101011011000111011101001011101 1000110111101111011101011001111101101000100110001001110100110001111011110001010000000111111010011011000111100001000101111101010011110011000101100010100111011011010111011001001011100 000110111110111000101011001111001101000100110001001110100111001011011000101010100000111110000011011000111100001000101111101110011110011010101100010101111011001010111011101001011100 101011011110111101110101100111100110100010011000100111010011010011111000101100100010011110010011011001111100011000101111001010001110011000101100011100111011010010111011001001111100 101011011110011101110101101111101101000100110001001111100110001111011110101100000100111111010011011000010010011000101110101010001110011100101100010101101011001010111010001001011100 1101101101001111101011110011110011010001001100010011111111010101101100010111100000000111101001101100111110001100010111111101000111011110011110001110111110011010111011101001011100 01111011101111010101011001111101101000110111001001110100010101100011110001100001010001111010011111001111100001100101111101010001110011100101000010101111110011010111011101001011100 001001011010011101010101100111110110100010011000100111110001010111100100010110000001001111101001101100111111100100010111001010011110011100101100010101111011001010111011001001011100 010110110001110101010110011100111100010011000100110100110011111000100101000000111101001101100111110001000101110010100011100111001011000101011110100010101110110100101100 0101101110011100010101100111101101000100110001001110100110101110011000111000100010111110100110110011111001100010111001101001111101110110110011010111111001010111011001001011101 100011011110101101010101100111100110100011111010100111011011010111101100010111000000001111001001101100111110000100010111110101001111101110010110101010111111001010111011001001011001 年

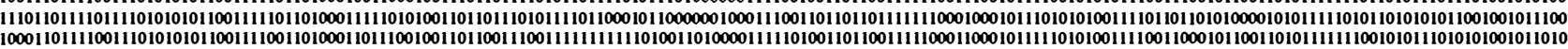
0010110110100111010101011001111001111000100110101001110100010001011011000100101100010011110011011011001111100011000101110101010010111011001101100110101111011011010111011001001011100 010110100100111010101011001111001101000110010001001110110110101011010000101000100000011111010011011001111100011000101111011010011110011000101100110101111011011000111011001001010000 010110111100111000101011001111101101000100111101001110100010001111111001101000100000011110010011011001111110001000101111101110011111011011101101010101111111001001111010001001010100 010110101100011011101011001111001101000110110001001111100110001111011110101110000000010111010011011011111100011000101111100100100110111000101001010111101011011010101010001101010100 1010110101100011010101011001111101101000100110000101110100110101001010110101010000000011010000011011000111110001000101110001010001110011000101101011101111011011010101011001001010100 1010100111100111010111011001111101101000100110001001110110010101011011000101101000000011111010011011001101110001000101111001110011110011000001001010101101011010010111011001001010101 1010110111101111010100011001111001111000100110001001110100010001011011000101110000000011110010011011001111100011000101111001010011111011000101101010101101010011010111011001001011001 1010110111100111010101011001111101101000100110001001110100010001011011101011010000001011100001101100111110101100010111010101000111001100010100001010011111001101011101110100101100

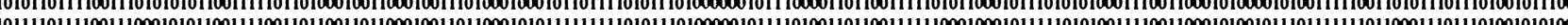
1111110001000101111101010011110011000101001011101111111011000111011101001010100 1010101111100111010101011001111101111000100110001001110100110101111011000101110000010111111010011011001111100011000101110001010001110011001101000010100101111010010111011001001011100 1011010111100111010101011001111101101000100110000101100110010101011011000010100001000010111000011011001111100011000101110101110010110011100101000010100101011001010101011101001011100 1010110110100011010101011001111001101000100110010101100110110001100011000001100100000011110000011011001111100110001111110101000111011000101001010101101110001011111011001011011100 101011011110001101010101100111110110100010011000010110010001000111111110101111100010011110010011011001111100011000101111001010001111011110101001010101111111001010111011001001011100

Apêndice 4. Matriz binária obtida a partir da leitura de fotografias de géis de agarose $1,4 \%$, contendo produtos de amplificação via RAPD-PCR do DNA da cigarrinha-do-milho, Dalbulus maidis, coletadas em quatro áreas experimentais localizadas em Anastácio/MS nas safras 1998/1999. Áreas I e II - plantio do milho em única safra anual há pelo menos 5 anos; áreas IV e V - áreas de pastagem sem plantio de milho há mais de 5 anos. As letras ao lado da identificação das áreas indicam $\mathrm{A}$ - coleta no ínicio da safra do milho e B- coleta no meio ou final da safra. 
CHA-1

CHA-2

CHA-3

CHA-4

CHA-5

CHA-6

CHA-7

CHA-8

CHA-9

CHA-10

BJS-2

BJS-3

BJS- 4

BJS.5

BJS-6

BJS.7

BJS.8

BJS-9

BJS-10

ANA-1

ANA-2

ANA-3

ANA-4

ANA-5

ANA-6

ANA-7

ANA-8

ANA-

PIR-1

PIR-2

PIR-4

PIR-5

PIR-6

PIR-7

PIR-8
PIR-9

PIR-9
PIR-10

MOS-1

MOS-2

$\operatorname{MOS}-3$

MOS- 4

MOS-5

MOS-6

MOS-8

MOS-9

MOS-9
MOS-10

1111011111111011110101001101111111111101011000010011101100100010101101110011110100000100110111111011011011110000111010101011100011011111001101111111011111111 1100111110110111101001111011111011111010100001100111011001000101011010100111001000001001101111110111110111111010110110010111100110011110011111011111011111111 1111011111011011110100011101111101101101110000011011001100101010101101011001100100001110110111110110110111100011110101010111100110111110011101011111011111111 01101111101101111010101110111110111111010001010001101100101110101101110011100100000110110111111011011011110100111011101011110011011111001110101111101111111 1011011111111011110110010101111111111010100100100110011001010001011010100011111110101101101111110010111110100011110100100111101110011110011001011011111011111 111011111111101101101001101111101111111010100010011101100101100101101010001100100001110010111111001011011111001011010101011100011001111001101101101101101111 10111111011100111100001101111101111111100000110111011101001100011010100011101000101101101111111101101111010001001001101111001101111001100101101101111111 10100111111101111110011110111110110100101100001001110110010011000110001001110000000111011011111101111101111010111101000101111001101111100111111001001111111 111101111111011110101011101111101111111010000011011001100110111101101010101110001001110110011111011110111100011000100010111100110111110010101011011011011111 1011011111011011110100011101111101111111010000010011011101100100101101010001110000001110110111111011111111110000111011101011110011101111001110101101101101111 111101111111011110100011111111111111111110001100110011001000001111010100111000011001101101111110111110111100011110100110111000110011110011111110111111011111 1111011111110111101001111011111111111010100000100110011001010101011000100011001010001111101011110110110111100011110100110111000110011110011011011011011111111 111101011111011110100011101111111111111010000010011001100101000101101010011111100001110111111111010110111100010110110010111001111111110011101011011011111111 10110111111101111011000110111111111111111000011011101101100010101100010011110001100110110101111011011011110001111011010011100010011110101111101111011111111 11110111110110011101000011011111111110101100001001110110010111010000001001111010110101011011111011111011110001111011101011100010001111001111101111101111111 101101111111101111110001110111110111111010000010011001100101111001101010001110100100111110111111011011011110001111010011011100011011111001101101111111111111 10100111111110111101000111011111111110110100000110110011001000001011011110111101000000101101011110110110111101010010110111111000111111110010111011001111011111 11110111111101111110001110111110111111111010010011001100101010101101010011110100000110110111111011011011010001011110010011100010111111001111110011111111111 11110111111101111010101101111101101111110000110110011011011100011010100111100000011101101111110110110110101010110100111111000110111110011101011111011111111 11110111111101111010001110111111111111010100110011001100100110101101010011101000100111111011110010110111100000110100110111000110111110011001011111011011111 10110111111101111010001110111110111111101000001001100110110010010110001000111010010011110101111001011011110000111010101111100111111111011111001111011011101 11110111110110111101000011111111011011110100000100110011001011001011000100011110001011101101111110110110110100000110100011111100110010110010011110011101111101 1111011111111111100100111101111111111110110000100110011001011001111000100111001010001111101011110110110110100000110101110111000110011110010111011111011111111 11110111101101110010000110111111111111010000010011001100101110101100010011111000000111110101111011011011110001111011101111101011001111001101111011101111111 1011011110110111001001111011111011111011110000100110011001011001011010100111001010001001101011110110110110100000110111010111100111011110011111011111011111011 111101111111011100100011101111100001001110001110111001100101100101101010001101000001010110101110001011011010111011011000111100011011111001101111011111011111 10110110111110111010001110111101111101010000010011001101101110101001000011100100001110110111111001011011110001111000111011100011001111001111101111011111111 1111011111111011110100011101111001111110100000100110011001011101011001111011101000010101101111110110110111110001110100010111000110011110011101011111011111111 010011111111011110110011111111111111111110000100110011001011101011010100011010000011101101101010110110111100011110100011111000110111110011101011111011111111 1110111111110111101000011111111011110110100100100110011001011001010010100111001011000011101111110110110111110011110101100111000110011100001101111111011111111 10110111111101111010000110111111011111010000010001001100101010101101110001100100101110110111111011110111100111100101110111101110011110010111011111011111111 10110111111101111010000110111110111111010000010011101100100110101101110011100000001110110111111011110111100011110101110111101110110110010111110100011111111 11110111111110111101000011011111100110101000001001110110110111010110001001110000000111011011111011111011110000110011011111110111011011011001101111101111111 101101101111011110100001101111101101111110011100010011001011101011011100111100000101111101111110010110111110111110100010111101110010110011111011011011111111 10110111110110111101000011011111011111010110000100110010001001100001010010111000001010111101111110111110111110101110110111111101110011110011111011111011111111 111101111111011110110001101111101111110100000100110011001001001011001100011010000101001101111110110100111101001110100110111101110111100111110111101111111 1011111111011001110100001101111101111101010000010011101100100010101100010001110000100110110111111011111011110001111010001011110111111110011111011011011111111 10110111111101110010111110111100100111010000010011001100100110101101010001100100001110111111110110110111100011110101111111000110010110011101011011011111111 101100011101101111110000110111110111110101000001000100110010011010110101001110100000111011011111011111011110000111011110011110011001111001011111011101111101 11110001111110111101000011011111111111110100000100110011001001100011010100111001000101001111110110111110111100001110100100111100110111100011101011011011111111 101101111111001100100111101111111111111110000100111011001010101011000100011101001011101101101110111110110100011110111100111000110111110011111110111011011111 10110111111101111010001110111110100100101100011011100110010101010110001000111010000111111011011101111011010011110111110111001110111100111110111101111111 1011011111110111101000111011111011111101100001001110110010100010110101000111010000101011011011111111011010001101011110011100111011111001111110111011111111 111101111111011110100011101111101111011010000110011101101101000101100110001110100001110110111111011110110100000110111100111001110111110011111011111011011111 01101111111101110010101110111110111111011000110011001101101000101010010011100000001110110111111111110110100001110110100111000110111110011111110011011111111 1010111111101111010001110111110100100111000011011110110010100010110011000111000000101011011111111111011010001111011111011100011011111001111101111011111111 1011011111111011110100011101111001111111110001100011011011000001101000101011001000010110101111110111110110100011110110100111001110111110011011011111011111111 101101101111101110010011110111100111111111000010011101100101000101100010001100100001011110011111111110110100001110100100111001110111110011011011111011111111 001101111111001100000000101111001111111110000100111011001010101111010100011111000011111101111111111110110100011110111010111001110111110011111011111011111111 10110110111110111101000111011111010010010100001101110011001000101011001100011111000010111111111100111110110100011110100110111001110110110011011011111011011111

\section{Apêndice 5. Matriz binária obtida a partir da leitura de fotografias de géis de agarose $1,4 \%$, contendo produtos de amplificação via RAPD-PCR do DNA da cigarrinha-do-milho, Dalbulus maidis, coletadas em cinco municípios brasileiros: Chapecó/SC (CHA), Bom Jardim da Serra/SC (BJS), Anastácio/MS (ANA), Piracicaba/SP (PIR) e Mossoró/RN (MOS).}

